\title{
High Diversity in Urban Areas: How Comprehensive Sampling Reveals High Ant Species Richness within One of the Most Urbanized Regions of the World
}

\author{
François Brassard ${ }^{1,2, *}$, Chi-Man Leong ${ }^{1,3}$, Hoi-Hou Chan ${ }^{4}$ and Benoit Guénard ${ }^{1}$ \\ 1 The Insect Biodiversity and Biogeography Laboratory School of Biological Sciences, The University of Hong \\ Kong, Pok Fu Lam Rd, Lung Fu Shan, Hong Kong SAR, China; chimanleo@gmail.com (C.-M.L.); \\ zeroben@gmail.com (B.G.) \\ 2 Research Institute for the Environment and Livelihoods, Charles Darwin University, \\ Darwin, NT 0810, Australia \\ 3 Macao Science Center, Avenida Dr. Sun Yat-Sen, Macao SAR, China \\ 4 Division of Nature Conservation Studies, Instituto Para Os Assuntos Municipaís, Macao SAR, China; \\ hhchan@iam.gov.mo \\ * Correspondence: francois.brassard.bio@gmail.com; Tel.: +61-423-200-842
}

Citation: Brassard, F.; Leong, C.-M.; Chan, H.-H.; Guénard, B. High Diversity in Urban Areas: How Comprehensive Sampling Reveals High Ant Species Richness within One of the Most Urbanized Regions of the World. Diversity 2021, 13, 358 https://doi.org/10.3390/d13080358

Academic Editor: Michael Wink

Received: 2 July 2021

Accepted: 29 July 2021

Published: 4 August 2021

Publisher's Note: MDPI stays neutral with regard to jurisdictional claims in published maps and institutional affiliations.

Copyright: (c) 2021 by the authors. Licensee MDPI, Basel, Switzerland. This article is an open access article distributed under the terms and conditions of the Creative Commons Attribution (CC BY) license (https:// creativecommons.org/licenses/by/ $4.0 /)$.
Abstract: The continuous increase in urbanization has been perceived as a major threat for biodiversity, particularly within tropical regions. Urban areas, however, may still provide opportunities for conservation. In this study focused on Macao (China), one of the most densely populated regions on Earth, we used a comprehensive approach, targeting all the vertical strata inhabited by ants, to document the diversity of both native and exotic species, and to produce an updated checklist. We then compared these results with 112 studies on urban ants to illustrate the dual roles of cities in sustaining ant diversity and supporting the spread of exotic species. Our study provides the first assessment on the vertical distribution of urban ant communities, allowing the detection of 55 new records in Macao, for a total of 155 ant species (11.5\% being exotic); one of the highest species counts reported for a city globally. Overall, our results contrast with the dominant paradigm that urban landscapes have limited conservation value but supports the hypothesis that cities act as gateways for exotic species. Ultimately, we argue for a more comprehensive understanding of ants within cities around the world to understand native and exotic patterns of diversity.

Keywords: biological invasions; biodiversity; species checklist; urban ecology; conservation

\section{Introduction}

Over the past century, urbanization has increased drastically in most regions around the world [1-3]. This increase threatens biodiversity [4-6], with pollution [7-9], habitat loss [10], and the spread of invasive species [11] being major causes of local species extinction or population decline. As such, urban habitats have historically been considered as species-poor concrete jungles [12]. However, urban environments are not necessarily depauperate ecosystems, and may, in fact, have some degree of conservation value by harboring native species [13]. Recent studies suggest that urban habitats can harbor a high diversity of both native (including endemic species) and non-native species, and even, sometimes, surpass surrounding rural areas in terms of species richness [12-16]. The survey and monitoring of biodiversity within cities may thus allow the identification of novel habitats and species worthy of protection within urban matrices. In particular, urban habitats including large and high quality patches of green spaces and forest fragments may still support high species diversity [17-20]. How much biodiversity these areas can contain is still open for debate, but it is paramount to understand the potential conservation value of urban centers. 
Beyond assessing the number of species in cities, another crucial component to consider is the composition and identity of the species present. Indeed, cities can facilitate invasions by non-native species in part due to their high level of disturbance, which provides ecological niches suitable for many exotic species [21-23]. Moreover, the constant flux of merchandise in and out of urban centers through airports, harbors, and train stations make them the ideal gateways for exotic species introductions with the common arrival of new propagules [24-26]. Consequently, surveying urban centers and their surroundings to detect new arrivals is essential to limit their spread and mitigate their potential impact on native biodiversity. This is especially true for coastal regions, which host the highest richness of exotic species [27], and, in the case of China, may represent a source of spread towards more inland regions [28].

To evaluate the biodiversity value of urban environments, surveying all flora and fauna would be ideal, but unrealistic, especially for tropical and subtropical regions where there is limited data and taxonomic knowledge. As such, ecological surveys must select a subset of taxa representing useful biodiversity proxies. For conservation monitoring purposes, ants represent an ideal taxon [29]. Indeed, their taxonomy is relatively well-resolved in comparison with most other diverse insect groups, and they can be sampled through the use of standardized and replicable protocols [30]. They are also ecologically and taxonomically diverse, abundant, and ubiquitous [31]. Moreover, they are adequate bioindicators [32,33], play key ecological roles as predators, scavengers, and herbivores [31,32,34,35], with some species acting as ecosystem engineers by modifying soil properties [34].

Ants also include some of the most damaging invasive species, impacting native ants [35-37], non-ant invertebrates [38], vertebrates [39], and plant communities [40], ultimately causing ecosystem disruptions [41]. Invasive ant species can also negatively impact human socioeconomic activities such as farming or education [42], whereas others are considered household pests [43,44], with some exotic species even acting as vectors of pathogens in hospitals [45,46]. Thus, surveying the ant fauna of urban regions and producing ant species checklists should be an important tool not only to evaluate the conservation value of cities, but also to record the worldwide spread of exotic species.

To date, the majority of studies have been limited to ecological studies (Table 1), limited in time and space, and using only a subset of sampling methods to characterize urban ant communities. However, establishing an exhaustive list of a region's ant fauna presents multiple concerns and challenges. For instance, within a specific habitat, and especially within tropical regions, distinct ant species are stratified along the vertical strata (i.e., from underground to the canopy) [47-51]. Generally, ants can be classified into three broad categories: arboreal, epigeic (i.e., ground surface-dwelling, including ants living in leaf litter), and hypogeic (i.e., subterranean). To perform a complete inventory of ants within a region, surveys should, thus, include the different dimensions of this vertical stratification by using methods targeting species from each microhabitat. Unfortunately, most studies in urban habitats use sampling methods focusing mainly or solely on epigeic ants [52], thereby potentially under-estimating the species richness and composition of local communities, as well as the magnitude of invasions. Additionally, this may misrepresent the diversity of hypogeic and arboreal ants within urban habitats and overlook the potential discovery of undescribed species [53-55].

Considering the current expansion of urban habitats [1], describing patterns in urban ant diversity is of great urgency. This is essential to foster biodiversity in cities, but also to gain a better understanding of which factors may facilitate the spread of exotic species. To the best of our knowledge, however, few cities have comprehensive ant species checklists, especially in tropical Asia (Figure 1, Table 1), which makes meaningful comparisons in urban biodiversity challenging at best. More biodiversity surveys and checklists are, thus, required to address this issue. 


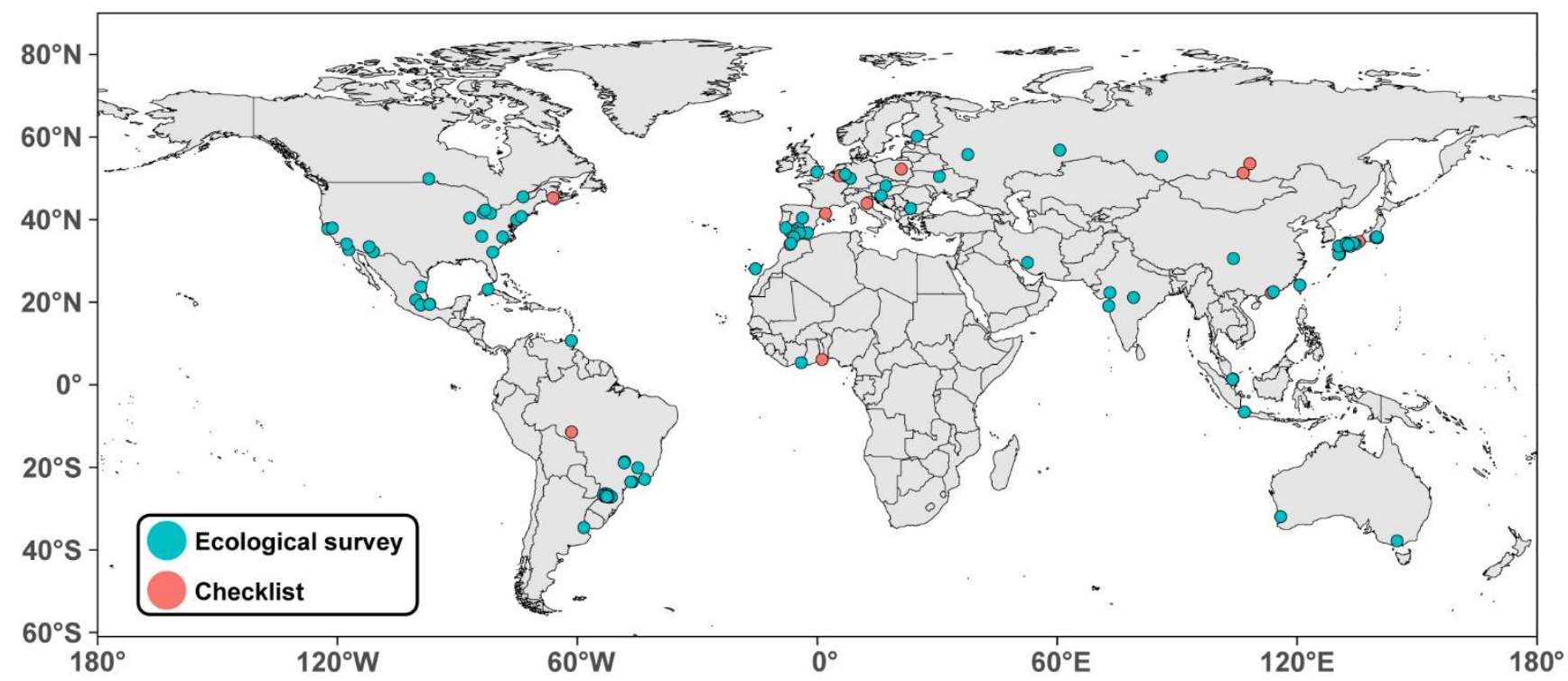

Figure 1. World map showcasing the locations of studies compiled in Table 1. Points show urban locations for which ant species richness estimates were available. Color indicates the type of study (i.e., ecological survey or checklist, see legend).

One such region is the Guangdong-Hong Kong-Macao Greater Bay Area, a major Asian megalopolis [56]. Located in subtropical China, it covers an area of 56,000 $\mathrm{km}^{2}$ and has a combined population of 68 million people [56]. Within the Greater Bay Area, Macao can be distinguished by its human density, which exceeds $20,000 \mathrm{hab} . / \mathrm{km}^{2}$, making it the most densely populated region on the planet $[57,58]$. Macao also represents an historical global hotspot in its role within the global trade exchange, first within the Portuguese network and then within China [59,60], making it particularly vulnerable to biological invasions. Finally, the development of Macao has led to a complex matrix of habitats with various levels of disturbance. As such, Macao represents a unique opportunity to better understand how much biodiversity a city characterized by extreme urban development may contain and assess the role of cities as gateways for exotic species.

Following the publication of a preliminary checklist of the ant species of Macao [53] and the discovery of a new subterranean ant species [61], a new survey was conducted across Coloane Island, in the southern half of Macao. To our knowledge, our survey is the first to use an exhaustive sampling approach covering all vertical strata inhabited by ants within an urban area (i.e., arboreal, ground-dwelling, and subterranean). We hypothesized that this sampling coverage would uncover a substantial amount of new species records, give a fair representation of the ant species richness of Macao, and detect new introductions of exotic species. Moreoever, we expected that this methodology, which could be replicated across cities around the world, would be particularly useful for finding cryptic and potentially undescribed species. Finally, we compare our results with previous published studies on urban ants to illustrate the potential that cities may represent for ant diversity, but also more broadly for other insect groups. 
Table 1. Ecological and taxonomic studies that produced ant species richness values for a city. Studies are classified by a function of their study region and ranked by the function of the overall species richness retrieved. Studies not providing a complete species list or without enough information on habitats sampled were not included. ${ }^{*}$ ) Complete list of species not provided in article, $\left({ }^{* *}\right)$ a combination of 3 articles by the same author and in the same city, and $(* *)$, richness value is a combination of more than one urban region.

\begin{tabular}{|c|c|c|c|c|c|c|c|}
\hline References & Study Type & Locality & Latitude & Area $\left(\mathrm{km}^{2}\right)$ & Natives & Exotics & Total \\
\hline \multicolumn{8}{|l|}{ Africa (7) } \\
\hline Kouakou et al. 2018 [62] & $\begin{array}{l}\text { ecological } \\
\text { survey }\end{array}$ & $\begin{array}{l}\text { Abidjan, Ivory } \\
\text { Coast }\end{array}$ & 5.3 & 422 & 170 & 6 & 176 \\
\hline Yeo et al. 2016 [63] & $\begin{array}{l}\text { ecological } \\
\text { survey }\end{array}$ & $\begin{array}{l}\text { Abidjan, Ivory } \\
\text { Coast }\end{array}$ & 5.3 & 422 & 83 & 8 & 91 \\
\hline Kasseney et al. 2019 [64] & checklist & Lomé (Togo) & 6.1 & 99.1 & 41 & 2 & 43 \\
\hline Taheri et al. 2017 [65] & $\begin{array}{l}\text { ecological } \\
\text { survey }\end{array}$ & Tangier, Morocco & 35.76 & 116 & 30 & 8 & 38 \\
\hline Bernard 1958 [66] & checklist & $\begin{array}{c}\text { Rabat, Kenitra } \\
\text { and Tangier, } \\
\text { Morocco }\end{array}$ & 34.3 to 35.8 & $\begin{array}{c}905 \text { (multiple } \\
\text { cities } \\
\text { included) }\end{array}$ & $5^{* * *}$ & $11^{* * *}$ & $16^{* * *}$ \\
\hline Bernard 1974 [67] & $\begin{array}{l}\text { ecological } \\
\text { survey }\end{array}$ & Kenitra, Morocco & 34.3 & 112 & 13 & 0 & 13 \\
\hline $\begin{array}{l}\text { Reyes-Lopez and } \\
\text { Carpintero } 2014 \text { [68] }\end{array}$ & $\begin{array}{l}\text { ecological } \\
\text { survey }\end{array}$ & $\begin{array}{c}\text { Las Palmas, } \\
\text { Canary Islands }\end{array}$ & 28.2 & 100.6 & 6 & 6 & 12 \\
\hline \multicolumn{8}{|l|}{ Asia (42) } \\
\hline Ito et al. 2001 [69] & checklist & $\begin{array}{l}\text { Bogor, Java, } \\
\text { Indonesia }\end{array}$ & -6.6 & 118.5 & 202 & 11 & 213 \\
\hline This study & checklist & $\begin{array}{l}\text { Macao, SAR, } \\
\text { China }\end{array}$ & 22.2 & 32.9 & 137 & 18 & 155 \\
\hline Leong et al. 2017 [61] & checklist & $\begin{array}{l}\text { Macao, SAR, } \\
\text { China }\end{array}$ & 22.2 & 32.9 & 88 & 10 & 98 \\
\hline Rizali et al. 2008 [70] & $\begin{array}{l}\text { ecological } \\
\text { survey }\end{array}$ & $\begin{array}{l}\text { Bogor, West Java, } \\
\text { Indonesia }\end{array}$ & -6.6 & 118.5 & 82 & 12 & 94 \\
\hline $\begin{array}{c}\text { Terayama 2005a,b and } \\
2014[71-73]\end{array}$ & $\begin{array}{l}\text { ecological } \\
\text { survey } * *\end{array}$ & Tokyo, Japan & 35.7 & 2194.1 & 54 & 0 & 54 \\
\hline $\begin{array}{l}\text { Matsumura and Yamane } \\
2012[74]\end{array}$ & $\begin{array}{l}\text { ecological } \\
\text { survey }\end{array}$ & $\begin{array}{l}\text { Kagoshima City, } \\
\text { Japan }\end{array}$ & 31.6 & 547.6 & 48 & 3 & 51 \\
\hline Liu et al. 2019 [75] & $\begin{array}{l}\text { ecological } \\
\text { survey }\end{array}$ & $\begin{array}{l}\text { Taichung City, } \\
\text { Taiwan }\end{array}$ & 24.2 & 2215 & $?$ & $?$ & $50 *$ \\
\hline Natuhara 1998 [76] & checklist & $\begin{array}{l}\text { Osaka City, } \\
\text { Japan }\end{array}$ & 34.7 & 225.2 & 44 & 5 & 49 \\
\hline Tan and Corlett 2012 [77] & $\begin{array}{l}\text { ecological } \\
\text { survey }\end{array}$ & Singapore & 1.3 & 728.3 & 38 & 4 & 42 \\
\hline Harada et al. 2012 [78] & checklist & Isa City, Japan & 32.1 & 392.4 & 40 & 0 & 40 \\
\hline $\begin{array}{l}\text { Iwata, Eguchi and } \\
\text { Yamane } 2005 \text { [79] }\end{array}$ & $\begin{array}{l}\text { ecological } \\
\text { survey }\end{array}$ & $\begin{array}{l}\text { Kagoshima City, } \\
\text { Japan }\end{array}$ & 31.6 & 547.6 & 37 & 2 & 39 \\
\hline Yamaguchi 2004 [80] & $\begin{array}{l}\text { ecological } \\
\text { survey }\end{array}$ & Chiba, Japan & 35.6 & 271.8 & 37 & 1 & 38 \\
\hline Park et al. 2014a [81] & $\begin{array}{l}\text { ecological } \\
\text { survey }\end{array}$ & $\begin{array}{l}\text { Fukuoka City, } \\
\text { Japan }\end{array}$ & 33.6 & 343.4 & 35 & 3 & 38 \\
\hline $\begin{array}{l}\text { Matsumura and Yamane } \\
2012[74]\end{array}$ & $\begin{array}{l}\text { ecological } \\
\text { survey }\end{array}$ & $\begin{array}{l}\text { Kagoshima } \\
\text { City, Japan }\end{array}$ & 31.6 & 547.6 & 36 & 2 & 38 \\
\hline Wang et al. 2012 [82] & $\begin{array}{l}\text { ecological } \\
\text { survey }\end{array}$ & $\begin{array}{c}\text { Shenzhen, } \\
\text { Guangdong, } \\
\text { China }\end{array}$ & 22.5 & 2050 & 29 & 6 & 35 \\
\hline
\end{tabular}


Table 1. Cont.

\begin{tabular}{|c|c|c|c|c|c|c|c|}
\hline References & Study Type & Locality & Latitude & Area $\left(\mathrm{km}^{2}\right)$ & Natives & Exotics & Total \\
\hline Khot et al. 2014 [83] & $\begin{array}{l}\text { ecological } \\
\text { survey }\end{array}$ & $\begin{array}{l}\text { Mumbai, } \\
\text { Maharashtra, } \\
\text { India }\end{array}$ & 19.1 & 603 & 25 & 3 & 28 \\
\hline Yamaguchi 2004 [80] & $\begin{array}{l}\text { ecological } \\
\text { survey }\end{array}$ & Tokyo, Japan & 35.7 & 2194.1 & 27 & 1 & 28 \\
\hline Hiroyuki 2012 [84] & checklist & $\begin{array}{l}\text { Matsuyama, } \\
\text { Japan }\end{array}$ & 33.8 & 429.4 & 28 & 0 & 28 \\
\hline Harada et al. 2021 [85] & $\begin{array}{l}\text { ecological } \\
\text { survey }\end{array}$ & $\begin{array}{l}\text { Kagoshima } \\
\text { City, Japan }\end{array}$ & 31.6 & 547.6 & 21 & 6 & 27 \\
\hline Miyake et al. 2002 [86] & $\begin{array}{l}\text { ecological } \\
\text { survey }\end{array}$ & $\begin{array}{l}\text { Hatsukaichi City, } \\
\text { Japan }\end{array}$ & 34.4 & 489.4 & 22 & 4 & 26 \\
\hline Tan et al. 2009 [87] & $\begin{array}{l}\text { ecological } \\
\text { survey }\end{array}$ & $\begin{array}{c}\text { Chengdu, } \\
\text { Sichuan, China }\end{array}$ & 30.7 & 885.6 & 24 & 2 & 26 \\
\hline Park et al. 2014b [88] & $\begin{array}{l}\text { ecological } \\
\text { survey }\end{array}$ & $\begin{array}{l}\text { Hiroshima city, } \\
\text { Japan }\end{array}$ & 34.4 & 906.7 & 21 & 4 & 25 \\
\hline $\begin{array}{l}\text { Touyama, Ogata and } \\
\text { Sugiyama } 2003 \text { [89] }\end{array}$ & $\begin{array}{l}\text { ecological } \\
\text { survey }\end{array}$ & $\begin{array}{l}\text { Hatsukaichi and } \\
\text { Hiroshima city, } \\
\text { Japan }\end{array}$ & 34.4 & $\begin{array}{c}1395 \\
\text { (multiple } \\
\text { cities } \\
\text { included) }\end{array}$ & $23^{* * *}$ & $1^{* * *}$ & $24^{* * *}$ \\
\hline $\begin{array}{l}\text { Harada and Yamashita, } \\
2019 \text { [90] }\end{array}$ & $\begin{array}{l}\text { ecological } \\
\text { survey }\end{array}$ & $\begin{array}{l}\text { Tokushima, } \\
\text { Japan }\end{array}$ & 34.1 & 191 & 21 & 1 & 22 \\
\hline Yasuda and Koike 2009 & $\begin{array}{l}\text { ecological } \\
\text { survey }\end{array}$ & Matsudo, Japan & 35.8 & 61.4 & $?$ & $?$ & $22 *$ \\
\hline $\begin{array}{c}\text { Malozemova and } \\
\text { Malozemov } 1999 \text { [91] }\end{array}$ & $\begin{array}{l}\text { ecological } \\
\text { survey }\end{array}$ & $\begin{array}{l}\text { Yekaterinburg, } \\
\text { Russia }\end{array}$ & 56.8 & 495 & 20 & 1 & 21 \\
\hline Harada 2020 [92] & $\begin{array}{l}\text { ecological } \\
\text { survey }\end{array}$ & Hioki City, Japan & 31.6 & 253.1 & 16 & 3 & 19 \\
\hline Roshanak et al. 2017 [93] & $\begin{array}{l}\text { ecological } \\
\text { survey }\end{array}$ & Shiraz, Iran & 29.6 & 240 & 19 & 0 & 19 \\
\hline Hosoishi et al. 2019 [94] & $\begin{array}{l}\text { ecological } \\
\text { survey }\end{array}$ & $\begin{array}{c}\text { Fukuoka City, } \\
\text { Japan }\end{array}$ & 33.6 & 343.4 & 17 & 1 & 18 \\
\hline Terayama et al. 2006 [95] & $\begin{array}{l}\text { ecological } \\
\text { survey }\end{array}$ & $\begin{array}{l}\text { Iwakuni City, } \\
\text { Japan }\end{array}$ & 34.2 & 873.7 & 14 & 2 & 16 \\
\hline Putyatina et al. 2017 [96] & $\begin{array}{l}\text { ecological } \\
\text { survey }\end{array}$ & Moscow, Russia & 55.8 & 2511 & 16 & 0 & 16 \\
\hline $\begin{array}{c}\text { Kumar and Archana } \\
2008 \text { [97] }\end{array}$ & $\begin{array}{l}\text { ecological } \\
\text { survey }\end{array}$ & $\begin{array}{l}\text { Vadodara, } \\
\text { Gujarat, India }\end{array}$ & 22.3 & 220 & 15 & 0 & 15 \\
\hline $\begin{array}{c}\text { Harada and Yamashita, } \\
2019 \text { [90] }\end{array}$ & $\begin{array}{l}\text { ecological } \\
\text { survey }\end{array}$ & Kochi, Japan & 33.6 & 309.2 & 15 & 0 & 15 \\
\hline Terayama et al. 2006 [95] & $\begin{array}{l}\text { ecological } \\
\text { survey }\end{array}$ & $\begin{array}{l}\text { Iwakuni City, } \\
\text { Japan }\end{array}$ & 34.2 & 873.7 & 12 & 2 & 14 \\
\hline Antonov 2008 [98] & checklist & $\begin{array}{c}\text { Irkutsk, Baikal, } \\
\text { Russia }\end{array}$ & 52.3 & 277 & 14 & 0 & 14 \\
\hline $\begin{array}{c}\text { Harada and Yamashita, } \\
2019 \text { [90] }\end{array}$ & $\begin{array}{l}\text { ecological } \\
\text { survey }\end{array}$ & $\begin{array}{l}\text { Takamatsu, } \\
\text { Japan }\end{array}$ & 34.4 & 375.4 & 14 & 0 & 14 \\
\hline $\begin{array}{c}\text { Harada and Yamashita, } \\
2019 \text { [90] }\end{array}$ & $\begin{array}{l}\text { ecological } \\
\text { survey }\end{array}$ & $\begin{array}{l}\text { Matsuyama City, } \\
\text { Japan }\end{array}$ & 33.8 & 429.4 & 12 & 1 & 13 \\
\hline Hosaka et al. 2019 [99] & $\begin{array}{l}\text { ecological } \\
\text { survey }\end{array}$ & Tokyo, Japan & 35.7 & 2194.1 & 11 & 0 & 11 \\
\hline Antonov 2008 [98] & checklist & $\begin{array}{l}\text { Gusinoozersk, } \\
\text { Baikal, Russia }\end{array}$ & 51.3 & $?$ & 7 & 0 & 7 \\
\hline Blinova 2008 [100] & $\begin{array}{l}\text { ecological } \\
\text { survey }\end{array}$ & $\begin{array}{l}\text { Kemerovo, } \\
\text { Russia }\end{array}$ & 55.4 & 282.3 & 7 & 0 & 7 \\
\hline
\end{tabular}


Table 1. Cont.

\begin{tabular}{|c|c|c|c|c|c|c|c|}
\hline References & Study Type & Locality & Latitude & Area $\left(\mathrm{km}^{2}\right)$ & Natives & Exotics & Total \\
\hline $\begin{array}{l}\text { Meshram et al. } \\
2015 \text { [101] }\end{array}$ & $\begin{array}{l}\text { ecological } \\
\text { survey }\end{array}$ & $\begin{array}{l}\text { Nagpur, } \\
\text { Maharashtra, } \\
\text { India }\end{array}$ & 21.2 & 393.5 & $\begin{array}{l}25 \text { (gen- } \\
\text { era) }\end{array}$ & 3 & $\mathrm{NA}^{*}$ \\
\hline Yong et al. 2017 [102] & checklist & $\begin{array}{l}\text { Pulau Aubin, } \\
\text { Singapore }\end{array}$ & 1.3 & 10.2 & $\begin{array}{l}35 \text { (gen- } \\
\text { era) }\end{array}$ & $\begin{array}{c}2 \text { (no } \\
\text { total } \\
\text { men- } \\
\text { tioned) }\end{array}$ & NA * \\
\hline \multicolumn{8}{|l|}{ Australia (6) } \\
\hline Ossola et al. 2015 [103] & $\begin{array}{l}\text { ecological } \\
\text { survey }\end{array}$ & $\begin{array}{l}\text { Melbourne, } \\
\text { Australia }\end{array}$ & -37.8 & 9993 & $59 *$ & $1 *$ & 60 \\
\hline Heterick et al. 2013 [104] & $\begin{array}{l}\text { ecological } \\
\text { survey }\end{array}$ & Perth, Australia & -32.0 & 6418 & 54 & 6 & 60 \\
\hline $\begin{array}{c}\text { Majer and Brown } \\
1986 \text { [105] }\end{array}$ & $\begin{array}{l}\text { ecological } \\
\text { survey }\end{array}$ & Perth, Australia & -32.0 & 6418 & 45 & 2 & 47 \\
\hline $\begin{array}{l}\text { Callan and Majer } \\
2009 \text { [106] }\end{array}$ & $\begin{array}{l}\text { ecological } \\
\text { survey }\end{array}$ & Perth, Australia & -32.0 & 6418 & 32 & 4 & 36 \\
\hline Heterick et al. 2000 [107] & $\begin{array}{l}\text { ecological } \\
\text { survey }\end{array}$ & Perth, Australia & -32.0 & 6418 & 19 & 8 & 27 \\
\hline $\begin{array}{c}\text { May and Heterick } \\
2000[108]\end{array}$ & $\begin{array}{l}\text { ecological } \\
\text { survey }\end{array}$ & Perth, Australia & -32.0 & 6418 & 18 & 8 & 26 \\
\hline \multicolumn{8}{|l|}{ Europe (28) } \\
\hline $\begin{array}{l}\text { Radchenko et al. } \\
2019 \text { [109] }\end{array}$ & checklist & Kyiv, Ukraine & 50.5 & 839 & 55 & 4 & 59 \\
\hline $\begin{array}{c}\text { Ordóñez-Urbano, } \\
\text { Reyes-López and } \\
\text { Carpintero-Ortega } \\
2008 \text { [110] }\end{array}$ & $\begin{array}{l}\text { ecological } \\
\text { survey }\end{array}$ & $\begin{array}{l}\text { Córdoba, Sevilla, } \\
\text { Málaga and } \\
\text { Cádiz, Spain }\end{array}$ & $36.5-37.9$ & $\begin{array}{l}>1800 \\
\text { (multiple } \\
\text { cities } \\
\text { included) }\end{array}$ & $?$ & $?$ & $59 * * * * *$ \\
\hline $\begin{array}{c}\text { Antonova and Penev } \\
2006[111-113]\end{array}$ & $\begin{array}{l}\text { ecological } \\
\text { survey }\end{array}$ & Sofia, Bulgaria & 42.7 & 492 & 54 & 0 & 46 \\
\hline Dauber 1997 [114] & $\begin{array}{l}\text { ecological } \\
\text { survey }\end{array}$ & Mainz, Germany & 50.0 & 97.7 & 49 & 0 & 49 \\
\hline $\begin{array}{l}\text { Dauber and } \\
\text { Eisenbeis [114] }\end{array}$ & $\begin{array}{l}\text { ecological } \\
\text { survey }\end{array}$ & Mainz, Germany & 50.0 & 97.7 & 46 & 0 & 46 \\
\hline $\begin{array}{l}\text { Reyes-Lopez and } \\
\text { Carpintero } 2014 \text { [68] }\end{array}$ & $\begin{array}{l}\text { ecological } \\
\text { survey }\end{array}$ & $\begin{array}{l}\text { Cordoba and } \\
\text { Seville, Spain }\end{array}$ & 37.4 and 37.9 & $\begin{array}{c}1393 \\
\text { (multiple } \\
\text { cities } \\
\text { included) }\end{array}$ & $39 * * *$ & $5^{* * *}$ & $44^{* * *}$ \\
\hline $\begin{array}{c}\text { Pisarski and } \\
\text { Czechowski } 1978 \text { [115] }\end{array}$ & checklist & Warsaw, Poland & 52.2 & 517.2 & 36 & 1 & 37 \\
\hline Pisarski 1982 [116] & checklist & Warsaw, Poland & 52.2 & 517.2 & 35 & 2 & 37 \\
\hline $\begin{array}{l}\text { Ruiz Heras et al. } \\
2011 \text { [117] }\end{array}$ & $\begin{array}{l}\text { ecological } \\
\text { survey }\end{array}$ & Madrid, Spain & 40.4 & 604.3 & 36 & 1 & 37 \\
\hline $\begin{array}{l}\text { Klesniakova et al. } \\
2016 \text { [118] }\end{array}$ & $\begin{array}{l}\text { ecological } \\
\text { survey }\end{array}$ & $\begin{array}{l}\text { Bratislava, } \\
\text { Slovakia }\end{array}$ & 48.1 & 367.6 & $?$ & 1 * & $36^{*}$ \\
\hline $\begin{array}{l}\text { Trigos-Peral et al. } \\
2020 \text { [119] }\end{array}$ & $\begin{array}{l}\text { ecological } \\
\text { survey }\end{array}$ & Warsaw, Poland & 52.2 & 517.2 & 32 & 2 & 34 \\
\hline $\begin{array}{l}\text { Reyes-Lopez and } \\
\text { Carpintero } 2014 \text { [68] }\end{array}$ & $\begin{array}{l}\text { ecological } \\
\text { survey }\end{array}$ & $\begin{array}{l}\text { Almeria, Cadiz, } \\
\text { Huelva and } \\
\text { Malaga, Spain }\end{array}$ & 36.5 to 37.3 & $\begin{array}{c}859.1 \\
\text { (multiple } \\
\text { cities } \\
\text { included) }\end{array}$ & $24^{* * *}$ & $8^{* * *}$ & $32 * * *$ \\
\hline $\begin{array}{c}\text { Ješovnik and Bujan } \\
2021 \text { [120] }\end{array}$ & $\begin{array}{l}\text { ecological } \\
\text { survey }\end{array}$ & Zagreb, Croatia & 45.8 & 641 & 30 & 0 & 30 \\
\hline $\begin{array}{c}\text { Behr, Lippke and Cölln } \\
1996[121]\end{array}$ & $\begin{array}{l}\text { ecological } \\
\text { survey }\end{array}$ & $\begin{array}{l}\text { Köln (Cologne), } \\
\text { Germany }\end{array}$ & 51.0 & 405.1 & 25 & 3 & 28 \\
\hline
\end{tabular}


Table 1. Cont.

\begin{tabular}{|c|c|c|c|c|c|c|c|}
\hline References & Study Type & Locality & Latitude & Area $\left(\mathrm{km}^{2}\right)$ & Natives & Exotics & Total \\
\hline Ślipiński et al. 2012 [122] & $\begin{array}{l}\text { ecological } \\
\text { survey }\end{array}$ & Warsaw, Poland & 52.2 & 517.2 & 27 & 0 & 27 \\
\hline $\begin{array}{c}\text { Behr and Cölln } \\
1993 \text { [123] }\end{array}$ & checklist & $\begin{array}{l}\text { Gönnersdorf, } \\
\text { Germany }\end{array}$ & 50.5 & 5.2 & 27 & 0 & 27 \\
\hline $\begin{array}{c}\text { Rigato and Wetterer } \\
2018[124]\end{array}$ & checklist & San Marino & 43.9 & 61.2 & 23 & 0 & 23 \\
\hline $\begin{array}{c}\text { Espadaler and } \\
\text { López-Soria } 1991 \text { [125] }\end{array}$ & checklist & $\begin{array}{c}\text { Sant Cugat, } \\
\text { Barcelona, Spain }\end{array}$ & 41.5 & 48.2 & 22 & 1 & 23 \\
\hline $\begin{array}{l}\text { Vepsäläinen, Ikonen and } \\
\text { Koivula } 2008 \text { [126] }\end{array}$ & $\begin{array}{l}\text { ecological } \\
\text { survey }\end{array}$ & Helsinki, Finland & 60.2 & 213.8 & 17 & 2 & 19 \\
\hline $\begin{array}{l}\text { Trigos Peral and Reyes } \\
\text { Lopez } 2018 \text { [127] }\end{array}$ & $\begin{array}{l}\text { ecological } \\
\text { survey }\end{array}$ & Beja, Portugal & 38.0 & 1146 & 17 & 0 & 17 \\
\hline $\begin{array}{l}\text { Vepsäläinen, Ikonen and } \\
\text { Koivula } 2008 \text { [126] }\end{array}$ & $\begin{array}{l}\text { ecological } \\
\text { survey }\end{array}$ & Helsinki, Finland & 60.2 & 185 & 16 & 0 & 16 \\
\hline Stukalyuk 2017 [128] & $\begin{array}{l}\text { ecological } \\
\text { survey }\end{array}$ & Kyiv, Ukraine & 50.5 & 839 & 16 & 0 & 16 \\
\hline $\begin{array}{l}\text { Reyes López and Taheri } \\
2018 \text { [129] }\end{array}$ & checklist & $\begin{array}{c}\text { Cádiz, } \\
\text { Andalusia, Spain }\end{array}$ & 36.5 & 12.1 & 6 & 9 & 15 \\
\hline Smith et al. 2006 [130] & $\begin{array}{l}\text { ecological } \\
\text { survey }\end{array}$ & London, UK & 51.5 & 1572 & 6 & 0 & 6 \\
\hline $\begin{array}{c}\text { Gaspar and Thirion } \\
1978[131]\end{array}$ & checklist & Liege, Belgium & 50.6 & 69.4 & 6 & 0 & 6 \\
\hline \multicolumn{8}{|l|}{ N. America (22) } \\
\hline Guénard et al. 2015 [16] & $\begin{array}{l}\text { ecological } \\
\text { survey }\end{array}$ & $\begin{array}{l}\text { Raleigh, NC, } \\
\text { USA }\end{array}$ & 35.8 & 380 & 77 & 12 & 89 \\
\hline $\begin{array}{l}\text { Nuhn and Wright } \\
1979 \text { [132] }\end{array}$ & checklist & $\begin{array}{l}\text { Raleigh, NC, } \\
\text { USA }\end{array}$ & 35.8 & 380 & 50 & 6 & 56 \\
\hline Baena et al. 2019 [133] & $\begin{array}{l}\text { ecological } \\
\text { survey }\end{array}$ & $\begin{array}{l}\text { Coatepec, } \\
\text { Mexico }\end{array}$ & 19.5 & 255.8 & 51 & 4 & 55 \\
\hline Menke et al. 2011 [134] & $\begin{array}{l}\text { ecological } \\
\text { survey }\end{array}$ & $\begin{array}{l}\text { Raleigh, NC, } \\
\text { USA }\end{array}$ & 35.8 & 380 & 49 & 5 & 54 \\
\hline $\begin{array}{l}\text { Miguelena and Baker } \\
2019 \text { [135] }\end{array}$ & $\begin{array}{l}\text { ecological } \\
\text { survey }\end{array}$ & Tucson, AZ, USA & 32.2 & 623.6 & 45 & 3 & 48 \\
\hline $\begin{array}{c}\text { Rocha-Ortega and } \\
\text { Castano-Meneses } \\
2015 \text { [136] }\end{array}$ & $\begin{array}{l}\text { ecological } \\
\text { survey }\end{array}$ & $\begin{array}{l}\text { Santiago de } \\
\text { Querétaro, } \\
\text { Mexico }\end{array}$ & 20.6 & 363 & 45 & 3 & 48 \\
\hline $\begin{array}{l}\text { Toennisson et al. } \\
2011 \text { [137] }\end{array}$ & $\begin{array}{l}\text { ecological } \\
\text { survey }\end{array}$ & $\begin{array}{l}\text { Knoxville, TN, } \\
\text { USA }\end{array}$ & 36.0 & 270 & 44 & 2 & 46 \\
\hline Suarez et al. 1998 [138] & $\begin{array}{l}\text { ecological } \\
\text { survey }\end{array}$ & $\begin{array}{l}\text { San Diego, CA, } \\
\text { USA }\end{array}$ & 32.7 & 964.6 & 42 & 4 & 46 \\
\hline $\begin{array}{l}\text { Gochnour et al. } \\
2019 \text { [139] }\end{array}$ & $\begin{array}{l}\text { ecological } \\
\text { survey }\end{array}$ & $\begin{array}{l}\text { Garden City, } \\
\text { Georgia, USA }\end{array}$ & 32.1 & 37.6 & 32 & 13 & 45 \\
\hline Savage et al. 2015 [140] & $\begin{array}{l}\text { ecological } \\
\text { survey }\end{array}$ & $\begin{array}{l}\text { New York, NY, } \\
\text { USA }\end{array}$ & 40.7 & 778 & 36 & 6 & 42 \\
\hline Baena et al. 2019 [133] & $\begin{array}{l}\text { ecological } \\
\text { survey }\end{array}$ & Xalapa, Mexico & 19.5 & 124.4 & 36 & 4 & 40 \\
\hline $\begin{array}{l}\text { Uno S. pers. Comm. In } \\
\text { Friedrich and Philpott } \\
\quad 2009 \text { [141] }\end{array}$ & $\begin{array}{l}\text { ecological } \\
\text { survey }\end{array}$ & Toledo, USA & 39.9 & 217.1 & $?$ & $?$ & 35 * \\
\hline $\begin{array}{c}\text { García-Martínez et al. } \\
2019 \text { [142] }\end{array}$ & $\begin{array}{l}\text { ecological } \\
\text { survey }\end{array}$ & $\begin{array}{l}\text { Ciudad Victoria, } \\
\text { Mexico }\end{array}$ & 23.7 & 188 & 28 & 4 & 32 \\
\hline $\begin{array}{c}\text { Fairweather et al. } \\
2020[143]\end{array}$ & checklist & $\begin{array}{l}\text { St-John, NB, } \\
\text { Canada }\end{array}$ & 45.3 & 316 & 30 & 0 & 30 \\
\hline
\end{tabular}


Table 1. Cont.

\begin{tabular}{|c|c|c|c|c|c|c|c|}
\hline References & Study Type & Locality & Latitude & Area $\left(\mathrm{km}^{2}\right)$ & Natives & Exotics & Total \\
\hline $\begin{array}{l}\text { Uno, Cotton and } \\
\text { Philpott } 2010 \text { [144] }\end{array}$ & $\begin{array}{l}\text { ecological } \\
\text { survey }\end{array}$ & Toledo, USA & 41.7 & 217.1 & 28 & 2 & 30 \\
\hline $\begin{array}{l}\text { Ivanov and Keiper } \\
2010 \text { [145] }\end{array}$ & $\begin{array}{l}\text { ecological } \\
\text { survey }\end{array}$ & $\begin{array}{l}\text { Cleveland, Oh, } \\
\text { USA }\end{array}$ & 41.5 & 201 & 28 & 1 & 29 \\
\hline $\begin{array}{l}\text { Uno, Cotton and } \\
\text { Philpott } 2010 \text { [144] }\end{array}$ & $\begin{array}{l}\text { ecological } \\
\text { survey }\end{array}$ & Detroit, USA & 42.3 & 370.1 & 26 & 1 & 27 \\
\hline $\begin{array}{c}\text { Lessard and Buddle } \\
2005[146]\end{array}$ & $\begin{array}{l}\text { ecological } \\
\text { survey }\end{array}$ & Montreal, CAN & 45.5 & 431.5 & 23 & 1 & 24 \\
\hline $\begin{array}{l}\text { Clarke, Fisher and } \\
\text { LeBuhn } 2008 \text { [147] }\end{array}$ & $\begin{array}{l}\text { ecological } \\
\text { survey }\end{array}$ & $\begin{array}{l}\text { San Francisco, } \\
\text { CAL, USA }\end{array}$ & 37.8 & 600.6 & 18 & 3 & 21 \\
\hline $\begin{array}{l}\text { Buczkowski and } \\
\text { Richmond } 2012 \text { [10] }\end{array}$ & $\begin{array}{l}\text { ecological } \\
\text { survey }\end{array}$ & $\begin{array}{l}\text { West Lafayette, } \\
\text { Indiana, USA }\end{array}$ & 40.4 & 35.8 & 19 & 1 & 20 \\
\hline $\begin{array}{c}\text { King and Green } \\
1995 \text { [148] }\end{array}$ & $\begin{array}{l}\text { ecological } \\
\text { survey }\end{array}$ & $\begin{array}{c}\text { Philadelphia, PA, } \\
\text { USA }\end{array}$ & 40.0 & 369.6 & 18 & 1 & 19 \\
\hline Staubus et al. 2015 [149] & $\begin{array}{l}\text { ecological } \\
\text { survey }\end{array}$ & $\begin{array}{c}\text { Claremont, CAL, } \\
\text { USA }\end{array}$ & 34.1 & 34.9 & 12 & 6 & 18 \\
\hline $\begin{array}{l}\text { Pećarević et al. } \\
2010 \text { [150] }\end{array}$ & $\begin{array}{l}\text { ecological } \\
\text { survey }\end{array}$ & $\begin{array}{c}\text { New York, NY, } \\
\text { USA }\end{array}$ & 40.7 & 778 & 10 & 3 & 13 \\
\hline $\begin{array}{l}\text { Thompson and } \\
\text { McLachlan } 2007 \text { [151] }\end{array}$ & $\begin{array}{l}\text { ecological } \\
\text { survey }\end{array}$ & $\begin{array}{l}\text { Winnipeg, } \\
\text { Manitoba, } \\
\text { Canada }\end{array}$ & 49.8 & 464.1 & 10 & 0 & 10 \\
\hline $\begin{array}{c}\text { Villar and } \\
\text { Ríos-Casanova [152] }\end{array}$ & $\begin{array}{l}\text { ecological } \\
\text { survey }\end{array}$ & $\begin{array}{c}\text { La Cantera } \\
\text { Oriente, Mexico } \\
\text { city, Mexico }\end{array}$ & 19.3 & 0.1 & 8 & 2 & 10 \\
\hline $\begin{array}{l}\text { Stahlschmidt and } \\
\text { Johnson } 2018 \text { [153] }\end{array}$ & $\begin{array}{l}\text { ecological } \\
\text { survey }\end{array}$ & $\begin{array}{c}\text { Stockton, CAL, } \\
\text { USA }\end{array}$ & 38.0 & 169 & 4 & 5 & 9 \\
\hline $\begin{array}{c}\text { Marussich and Faeth } \\
2009 \text { [154] }\end{array}$ & $\begin{array}{l}\text { ecological } \\
\text { survey }\end{array}$ & $\begin{array}{l}\text { Phoenix, AZ, } \\
\text { USA }\end{array}$ & 33.4 & 1341 & 7 & 1 & 8 \\
\hline \multicolumn{8}{|l|}{ S. and C. America (31) } \\
\hline $\begin{array}{c}\text { Pacheco and } \\
\text { Vasconcelos } 2007 \text { [155] }\end{array}$ & $\begin{array}{l}\text { ecological } \\
\text { survey }\end{array}$ & $\begin{array}{l}\text { Uberlândia, } \\
\text { Brazil }\end{array}$ & -18.9 & 4116 & 137 & 6 & 143 \\
\hline Santos et al. 2019 [156] & $\begin{array}{l}\text { ecological } \\
\text { survey }\end{array}$ & $\begin{array}{c}\text { Rio de Janeiro, } \\
\text { Brazil }\end{array}$ & -22.9 & 1221 & 116 & 4 & 120 \\
\hline $\begin{array}{c}\text { Santos-Silva et al. } \\
2016 \text { [157] }\end{array}$ & checklist & $\begin{array}{c}\text { Cacoal, } \\
\text { Rondônia, Brazil }\end{array}$ & -11.4 & 3793 & 98 & 4 & 102 \\
\hline $\begin{array}{l}\text { De Souza et al. } \\
2012 \text { [158] }\end{array}$ & $\begin{array}{l}\text { ecological } \\
\text { survey }\end{array}$ & $\begin{array}{c}\text { Mogi das Cruzes, } \\
\text { Brazil }\end{array}$ & -23.5 & 713 & 91 & 1 & 92 \\
\hline Lutinski et al. 2013 [159] & $\begin{array}{l}\text { ecological } \\
\text { survey }\end{array}$ & $\begin{array}{l}\text { Chapecó, Santa } \\
\text { Catarina, Brazil }\end{array}$ & -27.1 & 624.3 & 89 & 2 & 91 \\
\hline Munhae et al. 2014 [160] & $\begin{array}{l}\text { ecological } \\
\text { survey }\end{array}$ & $\begin{array}{l}\text { Alto Tietê region, } \\
\text { São Paulo, Brazil }\end{array}$ & -23.5 & $\begin{array}{c}1455 \\
\text { (multiple } \\
\text { cities } \\
\text { included) }\end{array}$ & $82^{* * *}$ & $5^{* * *}$ & $87^{* * *}$ \\
\hline Lutinski et al. 2013 [159] & $\begin{array}{l}\text { ecological } \\
\text { survey }\end{array}$ & $\begin{array}{l}\text { Palmitos, Santa } \\
\text { Catarina, Brazil }\end{array}$ & -27.1 & 350.7 & 81 & 4 & 85 \\
\hline Lutinski et al. 2013 [159] & $\begin{array}{l}\text { ecological } \\
\text { survey }\end{array}$ & $\begin{array}{c}\text { Campo Erê, } \\
\text { Santa Catarina, } \\
\text { Brazil }\end{array}$ & -26.4 & 478.7 & 82 & 3 & 85 \\
\hline Lutinski et al. 2013 [159] & $\begin{array}{l}\text { ecological } \\
\text { survey }\end{array}$ & $\begin{array}{l}\text { Xanxerê, Santa } \\
\text { Catarina, Brazil }\end{array}$ & -26.9 & 377.8 & 80 & 3 & 83 \\
\hline Lutinski et al. 2013 [159] & $\begin{array}{l}\text { ecological } \\
\text { survey }\end{array}$ & $\begin{array}{l}\text { São Miguel do } \\
\text { Oeste, Santa } \\
\text { Catarina, Brazil }\end{array}$ & -26.7 & 234.4 & 81 & 2 & 83 \\
\hline
\end{tabular}


Table 1. Cont.

\begin{tabular}{|c|c|c|c|c|c|c|c|}
\hline References & Study Type & Locality & Latitude & Area $\left(\mathrm{km}^{2}\right)$ & Natives & Exotics & Total \\
\hline Lutinski et al. 2013 [159] & $\begin{array}{l}\text { ecological } \\
\text { survey }\end{array}$ & $\begin{array}{c}\text { Abelardo Luz, } \\
\text { Santa Catarina, } \\
\text { Brazil }\end{array}$ & -26.6 & 953.6 & 81 & 2 & 83 \\
\hline Lutinski et al. 2013 [159] & $\begin{array}{l}\text { ecological } \\
\text { survey }\end{array}$ & $\begin{array}{c}\text { Concórdia, Santa } \\
\text { Catarina, Brazil }\end{array}$ & -27.2 & 800 & 80 & 2 & 82 \\
\hline Lutinski et al. 2013 [159] & $\begin{array}{l}\text { ecological } \\
\text { survey }\end{array}$ & $\begin{array}{c}\text { Pinhalzinho, } \\
\text { Santa Catarina, } \\
\text { Brazil }\end{array}$ & -26.8 & 128.3 & 76 & 4 & 80 \\
\hline Lutinski et al. 2013 [159] & $\begin{array}{l}\text { ecological } \\
\text { survey }\end{array}$ & $\begin{array}{l}\text { Joaçaba, Santa } \\
\text { Catarina, Brazil }\end{array}$ & -27.1 & 232.4 & 76 & 3 & 79 \\
\hline Morini et al. 2007 [161] & $\begin{array}{l}\text { ecological } \\
\text { survey }\end{array}$ & São Paulo, Brazil & -23.6 & 1521.1 & 76 & 3 & 79 \\
\hline Lutinski et al. 2013 [159] & $\begin{array}{l}\text { ecological } \\
\text { survey }\end{array}$ & $\begin{array}{c}\text { Seara, Santa } \\
\text { Catarina, Brazil }\end{array}$ & -27.1 & 312.5 & 75 & 3 & 78 \\
\hline Iop et al. 2009 [162] & checklist & $\begin{array}{l}\text { Xanxerê, Santa } \\
\text { Catarina, Brazil }\end{array}$ & -26.9 & 377.8 & 45 & 2 & 67 \\
\hline Caldart et al. 2012 [163] & $\begin{array}{l}\text { ecological } \\
\text { survey }\end{array}$ & $\begin{array}{l}\text { Chapecó, Santa } \\
\text { Catarina, Brazil }\end{array}$ & -27.1 & 624.3 & 63 & 3 & 66 \\
\hline Ilha et al. 2017 [164] & $\begin{array}{l}\text { ecological } \\
\text { survey }\end{array}$ & $\begin{array}{l}\text { Chapecó, Santa } \\
\text { Catarina, Brazil }\end{array}$ & -27.1 & 624.3 & 60 & 3 & 63 \\
\hline Josens et al. 2017 [165] & $\begin{array}{l}\text { ecological } \\
\text { survey }\end{array}$ & $\begin{array}{c}\text { Buenos Aires, } \\
\text { Argentina }\end{array}$ & -34.6 & 203 & 57 & 3 & 60 \\
\hline Kamura et al. 2007 [166] & $\begin{array}{l}\text { ecological } \\
\text { survey }\end{array}$ & $\begin{array}{l}\text { Mogi das Cruzes, } \\
\text { São Paulo, Brazil }\end{array}$ & -23.5 & 713 & 49 & 9 & 58 \\
\hline Santiago et al. 2018 [167] & $\begin{array}{l}\text { ecological } \\
\text { survey }\end{array}$ & $\begin{array}{c}\text { Divinópolis, } \\
\text { Minas Gerais, } \\
\text { Brazil }\end{array}$ & -20.1 & 192 & 55 & 0 & 55 \\
\hline $\begin{array}{c}\text { De Souza-Campana et al. } \\
2016 \text { [168] }\end{array}$ & checklist & São Paulo, Brazil & -23.6 & 1521 & 46 & 1 & 47 \\
\hline $\begin{array}{l}\text { Piva and de Carvalho } \\
\text { Campos } 2012 \text { [169] }\end{array}$ & $\begin{array}{l}\text { ecological } \\
\text { survey }\end{array}$ & São Paulo, Brazil & -23.6 & 1521 & 38 & 6 & 44 \\
\hline $\begin{array}{l}\text { Simonetti, Brito and } \\
\text { Luis } 2010 \text { [170] }\end{array}$ & $\begin{array}{l}\text { ecological } \\
\text { survey }\end{array}$ & $\begin{array}{l}\text { Havana City, } \\
\text { Cuba }\end{array}$ & 23.1 & 728.3 & $?$ & $?$ & $37^{*}$ \\
\hline Ribeiro et al. 2012 [171] & $\begin{array}{l}\text { ecological } \\
\text { survey }\end{array}$ & São Paulo, Brazil & -23.6 & 1521 & 33 & 3 & 36 \\
\hline $\begin{array}{l}\text { Lutinski and Mello } \\
\text { Garcia } 2005 \text { [172] }\end{array}$ & $\begin{array}{l}\text { ecological } \\
\text { survey }\end{array}$ & $\begin{array}{l}\text { Chapecó, Santa } \\
\text { Catarina, Brazil }\end{array}$ & -27.1 & 624.3 & 32 & 0 & 32 \\
\hline Lange et al. 2015 [173] & $\begin{array}{l}\text { ecological } \\
\text { survey }\end{array}$ & $\begin{array}{l}\text { Araguari, Minas } \\
\text { Gerais, Brazil }\end{array}$ & -18.6 & 2730.6 & 21 & 2 & 23 \\
\hline $\begin{array}{c}\text { Starr and Ballah } \\
2017 \text { [174] }\end{array}$ & $\begin{array}{l}\text { ecological } \\
\text { survey }\end{array}$ & $\begin{array}{l}\text { Port of Spain, } \\
\text { Trinidad }\end{array}$ & 10.7 & 12 & 23 & 0 & 23 \\
\hline Soares et al. 2006 [175] & $\begin{array}{l}\text { ecological } \\
\text { survey }\end{array}$ & $\begin{array}{l}\text { Uberlândia, } \\
\text { Minas Gerais, } \\
\text { Brazil }\end{array}$ & -18.9 & 4116 & 10 & 4 & 14 \\
\hline
\end{tabular}

\section{Materials and Methods}

\subsection{Geographic and Climatic Characteristics of Macao}

Macao is a special administrative region on the southern coast of China. It is located $60 \mathrm{~km}$ south-west of the Hong Kong special administrative region, separated from it by the pearl river delta. Macao's climate is characterized by dry winters and hot summers [176], with an average daily temperature of $22.8^{\circ} \mathrm{C}$ and an annual rainfall of $1967 \mathrm{~mm}$ [177].

In the 19th century, Macao's land surface was only $10.28 \mathrm{~km}^{2}$ but, following numerous reclamation projects, it now covers around $32.9 \mathrm{~km}^{2}[58,178]$. Despite its high urbanization, Macao still retains several nature parks consisting of young secondary forests, most of which are on Coloane Island. Macao's government started managing these forest patches 
in 1980, protecting them from wild-fires and establishing restauration plantations of Pinus massoniana and Acacia confusa [179].

\subsection{Sampling Effort and Collection Methods}

Most ant specimens examined were collected during a survey conducted in 2019, from March to October, across 21 plots in Coloane Island, Macao (Figures S1 and S2, Table S1). The survey focused on collecting ants within Coloane's nature parks, which consist of secondary forests, but also covered two golf courses and a mangrove site. To extensively sample the hypogeic, epigeic, and arboreal ants of Macao, we used a range of sampling methods during the 2019 survey. Across the 21 sites, we used 225 ground baits, hand collection, and 42 leaf litter extractions with Winkler bags. Half the Winkler extractions consisted of combining the leaf litter of $4 \times 1 \mathrm{~m}^{2}$ quadrats taken at each corner of a plot of $20 \times 20 \mathrm{~m}$ (i.e., standard area method), and half consisted of combining a few handfuls of leaf litter taken at 12 random locations within the same plot (i.e., species pool method). For a subset of 16 sites, we used 256 subterranean and 320 arboreal baits, and 1024 artificial nests. For more details on traps, baits, and nest design, see Brassard et al. (2020) [54]. Note that the nests were built following Booher et al. (2017) [180], and were mainly used to obtain sociometric data for the species collected (i.e., colony size and composition). The remainder of the specimens included are from collections made by hand or leaf litter extractions between 2015 and 2020 from different locations across Macao, with detailed collection information presented in the species accounts section.

\subsection{Sample Processing}

We processed samples by first sorting specimens to morphospecies, which we then stored in ethanol 70\%. For each morphospecies, we point-mounted at least one individual and labeled it with a locality and collection label. All specimens are currently located in the Insect Biodiversity and Biogeography Laboratory (IBBL) at The University of Hong Kong.

\subsection{Imaging}

We used a Leica DFC450 camera mounted on a Leica M205 C dissecting microscope to image mounted specimens of each species and morphospecies. We used the Leica Application suite v. 4.5 to take, stack, and enhance image montages. When necessary, we used Adobe Photoshop Lightroom to make final color corrections and diminish ghosting effects.

\subsection{Mapping Species Distributions and Urban Studies}

We used $R$ to produce all maps [181]. The maps shown at the south-east Asia scale use records at the country level, or the administration level for larger countries (e.g., China, India, and Japan). Following previous work [182,183], we used island boundaries instead of political boundaries for large islands. For maps centered on Macao, we used the GPS coordinates associated with each specimen to add their collection localities.

\subsection{Analyses}

We produced maps, bar graphs, heatmaps, species accumulation curves, and Venn diagrams using ggplot2 [184], whereas we used Adobe Illustrator to assemble the species account figures (Figures A1-A158). We produced species accumulation curves and diversity estimates using the package iNEXT [185].

\subsection{Literature Search}

To compile studies that produced a species checklist for cities, we performed a Scopus search using the following formula on the 9th of February 2021: "formicidae" AND "checklist" AND "city" OR "urban". We then pruned the resulting dataset manually by reading the abstracts and only keeping the studies that produced a total number of species for a city. We further added appropriate studies known by authors that were not present within the Scopus search. In particular, we use the literature information combined 
in GABI [186] to identify suitable articles on urban ants. We classified studies as either ecological or checklists. If a study was primarily hypotheses driven, with limited sampling efforts in time, habitats, or in the methods used, it was classified as ecological, whereas studies solely producing a species checklist, including records from previous published studies, were classified as checklists. Studies including other non-urban habitats outside the main city area, and for which detailed information did not allow to separate species composition and richness, were not considered.

\subsection{Notes on Invasion Status}

An understanding of the native and introduced ranges of species represents a fundamental step in the detection and management of biological invasions. However, for many species of ants, clear geographic boundaries between those ranges remain undetermined, either at global (e.g., uncertainty in the realm of origin) or regional scales (e.g., native vs. introduced range within a particular realm). Here, we thus distinguish three categories between native, exotic, and tramp species. For species that we could establish with some confidence whether or not they were introduced, we used the exotic and native status, respectively. We used the tramp status for species whose biogeographic origins were more uncertain in Macau or south China. Note that all species here labelled as tramps have been previously transported in other regions of the world and have established populations in non-native habitats. This demonstrates their potential to colonize new regions. Furthermore, these tramp species often occur within anthropogenic habitats. As such, tramp species, regardless of their potential non-native status, are important to consider from a management perspective, as they have the potential to invade non-native localities. The establishment of the native and exotic ranges for each species was based on the maps available on antmaps.org [186,187].

\subsection{Notes on Records}

Since the last publication of a species checklist for Macao [53], two studies with a focus on specific genera (i.e., Polyrhachis and Strumigenys) published new species records for the region $[54,55]$. Since all but one species record-Polyrhachis tyrannica [55]-are from specimens collected during our 2019 sampling, we here report these specimens, with the exception of $P$. tyrannica, as new records for Macao.

\subsection{Notes on Taxonomy}

To identify our specimens at species-level, we used the Insect Biodiversity and Biogeography Lab (IBBL) ant collection as a reference. For the especially challenging species, we relied on the taxonomic knowledge of Dr. Benoit Guénard. To verify our identification of the genera Nylanderia and Carebara, we shared stacked images with specialists familiar with their taxonomy, Dr. Jason L. Williams and Dr. Georg Fischer, respectively. When a species could not be identified at species level with certainty, we labelled it as "nr." the morphologically closest known species (e.g., Colobopsis nr. nipponica). If the unknown species was morphologically distinct but not identifiable, we used the unique morphospecies code their collector used to label it (e.g., Camponotus sp.1 FB).

\section{Results}

Our 2019 survey collected a total of 112 species and morphospecies from 46 genera and nine subfamilies. Among these, 51 species (46\%), 10 genera (22\%), and one subfamily (11\%) represented new records for Macao. We also found four additional species and one new genus record among the specimens opportunistically collected between 2017 and 2020. In total, the new records reported here include one subfamily, 11 genera, and 55 species and morphospecies (Figure 2, Table 2). The new genera reported for Macao are: Brachymyrmex (exotic), Buniapone, Dilobocondyla, Gesomyrmex, Iridomyrmex, Mayriella, Probolomyrmex, Proceratium, Pseudolasius, Rotastruma and Vollenhovia, while the Proceratiinae subfamily is here recorded for the first time. The overall number of ant species known 
from Macao thus increases by 55\%, from 100 to 155 species and morphospecies (Figure 2, Table 2), which represents the third highest urban ant diversity out of 123 entries (see Figure 1, Table 1). For images of these species and maps of their distribution in Macao and SE Asia, see Appendix A (Figures A1-A158).
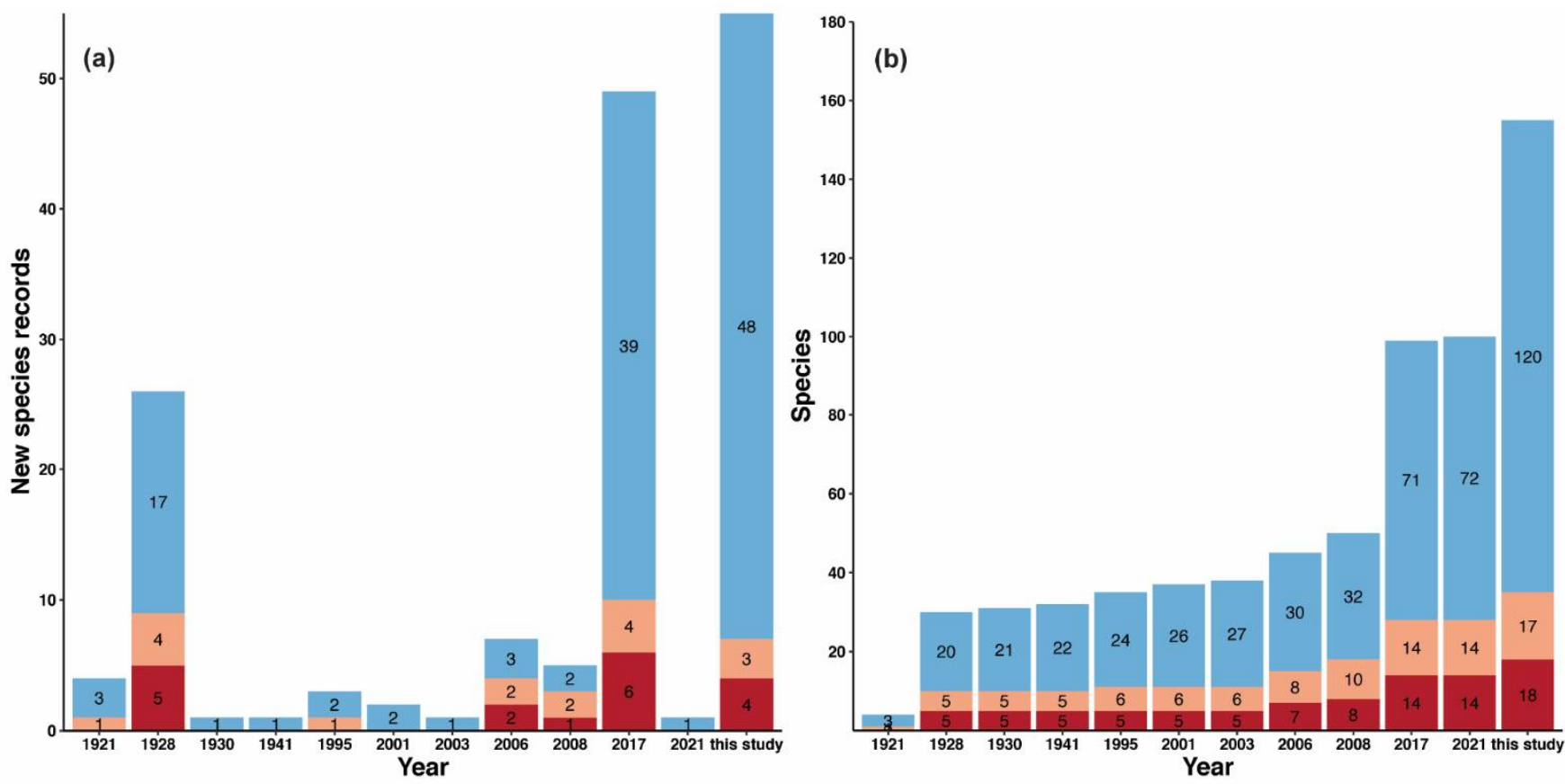

Figure 2. Number of new records per year in Macao. Bar plots showing (a) the number of new ant species record for Macao based on literature records and this study and (b) bar plots showing the accumulation of ant species found in Macao based on literature records and this study. The proportion of native species (blue), tramp species (light orange), and exotic species (dark red) are denoted within bar plots.

Table 2. Summary table of all new ant species records made in Macao over time with details on the number of reported ant species, subspecies, and morphospecies.

\begin{tabular}{|c|c|c|c|c|c|}
\hline Studies & Species & Subspecies & Morphospecies & Total per Year & Cumulative Total \\
\hline Wheeler 1921 [188] & 4 & 0 & 0 & 4 & 4 \\
\hline Wheeler 1928 [189] & 24 & 2 & 0 & 26 & 30 \\
\hline Wheeler 1930 [190] & 1 & 0 & 0 & 1 & 31 \\
\hline Wu 1941 [191] & 0 & 1 & 0 & 1 & 32 \\
\hline Tang et al. 1995 [192] & 3 & 0 & 0 & 3 & 35 \\
\hline Zhou 2001 [193] & 2 & 0 & 0 & 2 & 37 \\
\hline Xu 2003 [194] & 1 & 0 & 0 & 1 & 38 \\
\hline Hua 2006 [195] & 6 & 1 & 0 & 7 & 45 \\
\hline Eguchi 2008 [196] & 5 & 0 & 0 & 5 & 50 \\
\hline $\begin{array}{l}\text { Leong, Shaijo and } \\
\text { Guénard } 2017 \text { [53] }\end{array}$ & 41 & 1 & 7 & 49 & 99 \\
\hline $\begin{array}{l}\text { Wong and Guénard } \\
2021 \text { [55] }\end{array}$ & 1 & 0 & 0 & 1 & 100 \\
\hline This study & 40 & 0 & 15 & 55 & 155 \\
\hline
\end{tabular}

The sampling methods varied in their overlap for the species they collected (Figure 3). Of the 112 species collected during the 2019 survey, 10 species were only found in leaf litter extractions, five in ground baits, 10 in subterranean baits, 13 in hand collections, and eight in arboreal baits, whereas the other 66 were collected with more than one method. Artificial nests did not collect new species records nor unique species, but they did provide 
sociometric data for 15 species from a total of 913 nests recovered, for a colonization rate of $3 \%$ (Table S2).

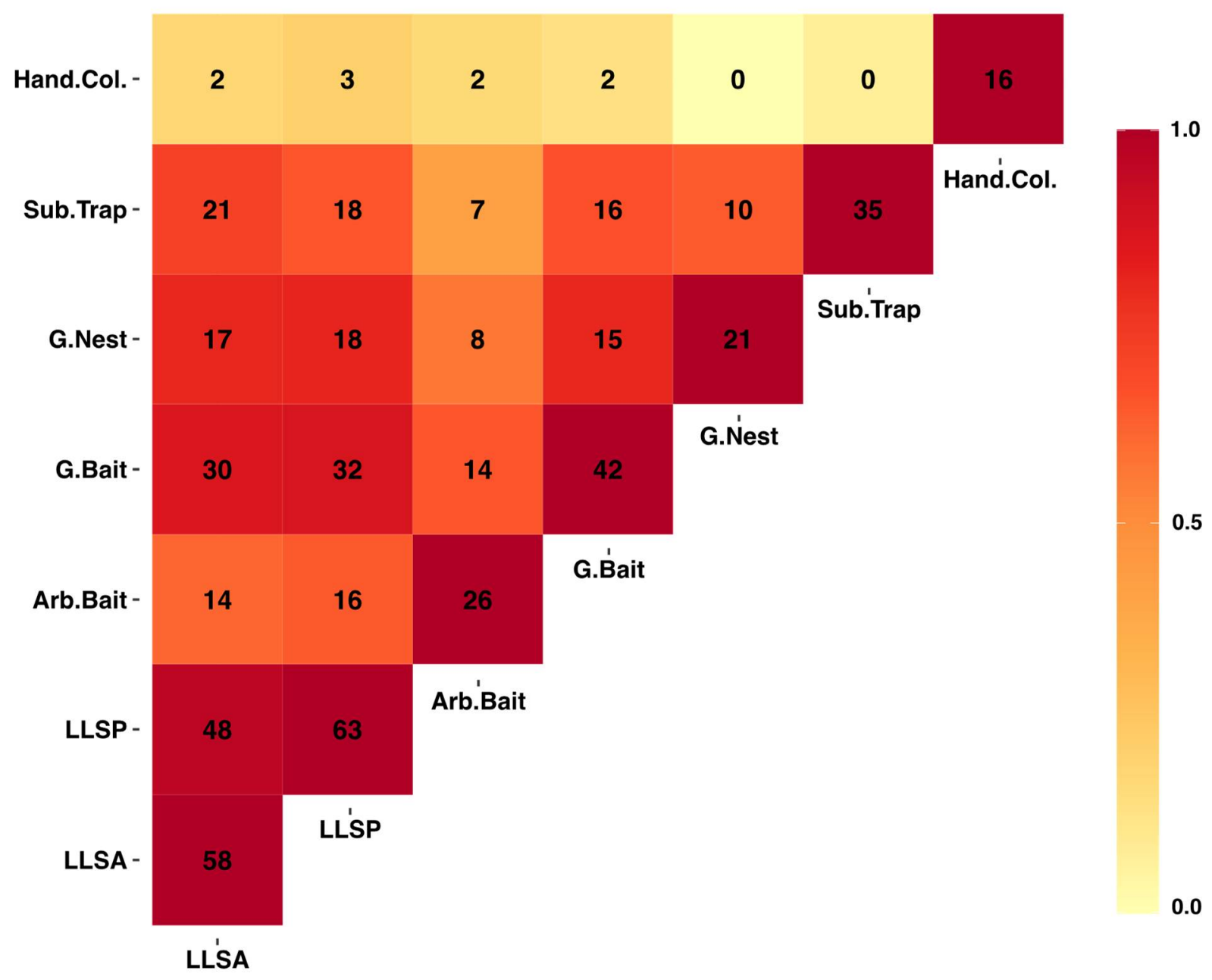

Figure 3. Heatmap showing the number of shared species between collection methods used in the 2019 survey. Color illustrates the strength of the correlation between sampling methods in the shared species they collect. The diagonal represents the total number of species collected for each method. Abbreviations are for hand collection (Hand. Col.), subterranean trap (Sub. Trap.), ground nest (G. Nest), ground bait (G. Bait), arboreal bait (Arb. Bait), leaf litter extraction with the species pool technique (LLSP), and leaf litter extraction with the standard area technique (LLSA).

We found few habitat generalists, with only seven species collected in all strata (Table 3, Figure 4)-Monomorium intrudens, M. floricola, Nylanderia sharpii, Pheidole megacephala, $P$. tumida, Tapinoma indicum, and T. melanocephalum - three of which (43\%) are exotics. Ten species were only collected within the subterranean stratum and 14 species only in the arboreal stratum (Table 3, Figure 4$)$. In contrast, most species were ground-dwelling $(n=52)$ or collected within two strata $(n=36)$. The highest proportion of new records found solely within one stratum were in the subterranean (9/10 species: $90 \%)$, arboreal ( $9 / 14$ species: $64 \%$ ), and then ground (25/52 species: $48 \%$ ) strata (Figure 4 ). 
Table 3. Summary checklist of the species recorded during previous studies and the current study in Macao. Status of species are mentioned as native, tramp, or exotic. The asterisk symbol $\left({ }^{*}\right)$ denotes new records. The dagger symbol $(\dagger)$ denotes morphospecies collected in 2019 that probably belong to previous records but could not be assigned a species name due to incomplete taxonomic descriptions (as such, they were not counted in the total number of species). The diesis symbol ( $\ddagger)$ denotes a species collected previously, but with a mislabeled status. An " $X$ " under the column Arboreal, Ground, or Subterranean indicates that this species was collected within this stratum during the 2019 survey. We left blanks for species not collected during the 2019 survey. For images of species and maps of their distribution in Macao and SE Asia, see Figures A1-A158. For detailed accounts of the material examined, see the species account section of the supplementary material.

\begin{tabular}{|c|c|c|c|c|c|c|c|}
\hline Subfamily & Genus & Species & Status & $\begin{array}{c}\text { Year of First } \\
\text { Published } \\
\text { Record }\end{array}$ & Arboreal & Ground & Subterranean \\
\hline AMBLYOPONINAE & Stigmatomma & nr. rothneyi & native & 1928 & - & $x$ & - \\
\hline \multirow[t]{15}{*}{ DOLICHODERINAE } & \multirow[t]{6}{*}{ Chronoxenus } & dalyi & native & 1928 & & & \\
\hline & & walshi & native & 2006 & & & \\
\hline & & wroughtonii & native & 1995 & & & \\
\hline & & $\begin{array}{l}\text { wroughtonii } \\
\text { formosensis }\end{array}$ & native & 2006 & & & \\
\hline & & t morpho1 & native & 2021 & - & $x$ & $X$ \\
\hline & & † morpho2 & native & 2021 & - & $x$ & $x$ \\
\hline & \multirow[t]{2}{*}{ Dolichoderus } & taprobanae & native & 1928 & & & \\
\hline & & nr. sibiricus & native & 2017 & $x$ & - & - \\
\hline & Iridomyrmex & sp. anceps cplx* & tramp & 2021 & - & $X$ & - \\
\hline & Ochetellus & glaber & tramp & 1928 & - & $x$ & - \\
\hline & \multirow[t]{3}{*}{ Tapinoma } & indicum & native & 2017 & $x$ & $x$ & $x$ \\
\hline & & melanocephalum & tramp & 1921 & $X$ & $X$ & $x$ \\
\hline & & sp. $1 \mathrm{FB} *$ & native & 2021 & $x$ & - & - \\
\hline & \multirow[t]{2}{*}{ Technomyrmex } & brunneus & tramp & 1995 & - & $X$ & - \\
\hline & & horni * & native & 2021 & - & $x$ & - \\
\hline DORYLINAE & Ooceraea & biroi & exotic & 2017 & - & $x$ & $x$ \\
\hline \multirow{24}{*}{ FORMICINAE } & \multirow{3}{*}{ Acropyga } & acutiventris & native & 2017 & & & \\
\hline & & sauteri & native & 1928 & & & \\
\hline & & sp. mo02 & native & 2017 & & & \\
\hline & Anoplolepis & gracilipes & exotic & 1928 & $x$ & $x$ & - \\
\hline & Brachymyrmex & patagonicus * & exotic & 2021 & $X$ & - & - \\
\hline & \multirow[t]{12}{*}{ Camponotus } & albosparus & native & 1928 & & & \\
\hline & & carin * & native & 2021 & & & \\
\hline & & irritans * & native & 2021 & - & $X$ & - \\
\hline & & lighti & native & 2017 & & & \\
\hline & & mitis & native & 1928 & $X$ & $x$ & - \\
\hline & & nicobarensis & native & 2017 & $x$ & $x$ & - \\
\hline & & parius & native & 1921 & & & \\
\hline & & vitiosus & native & 2017 & $x$ & - & - \\
\hline & & variegatus & tramp & 2006 & & & \\
\hline & & variegatus dulcis & native & 1928 & & & \\
\hline & & variegatus proles & native & 1941 & & & \\
\hline & & sp. $1 \mathrm{FB} *$ & native & 2021 & - & $X$ & - \\
\hline & \multirow[t]{2}{*}{ Colobopsis } & nr. nipponica & native & 2017 & & & \\
\hline & & nr. vitrea & native & 2017 & $X$ & - & - \\
\hline & Gesomyrmex & howardi * & native & 2021 & & & \\
\hline & Lepisiota & rothneyi & native & 1921 & - & $x$ & - \\
\hline & \multirow[t]{3}{*}{ Nylanderia } & amia & tramp & 1928 & & & \\
\hline & & bourbonica & tramp & 2006 & - & $x$ & - \\
\hline & & indica & native & 1928 & - & $x$ & - \\
\hline
\end{tabular}


Table 3. Cont.

\begin{tabular}{|c|c|c|c|c|c|c|c|}
\hline Subfamily & Genus & Species & Status & $\begin{array}{c}\text { Year of First } \\
\text { Published } \\
\text { Record }\end{array}$ & Arboreal & Ground & Subterranean \\
\hline & \multirow{8}{*}{ Paraparatrechina } & sharpii & native & 2021 & $X$ & $x$ & $X$ \\
\hline & & taylori ${ }^{*}$ & native & 2021 & - & $x$ & - \\
\hline & & vividula & exotic & 2006 & & & \\
\hline & & yerburyi & native & 1928 & & & \\
\hline & & sp. 3 BG * & & & - & $x$ & - \\
\hline & & sp. 6 BG * & native & 2021 & - & $x$ & - \\
\hline & & sauteri & native & 2006 & & & \\
\hline & & sp.1 BG * & native & 2021 & - & $x$ & $X$ \\
\hline & \multirow{8}{*}{$\begin{array}{l}\text { Paratrechina } \\
\text { Plagiolepis } \\
\text { Polyrhachis }\end{array}$} & longicornis & exotic & 1928 & - & $x$ & $x$ \\
\hline & & alluaudi ${ }^{*}$ & exotic & 2021 & $x$ & - & - \\
\hline & & confusa * & native & 2021 & - & $x$ & - \\
\hline & & demangei & native & 2017 & & & \\
\hline & & dives & native & 1995 & $x$ & - & - \\
\hline & & illaudata & native & 2017 & $x$ & $x$ & - \\
\hline & & latona * & native & 2021 & - & $x$ & - \\
\hline & & tyrannica & native & 2021 & & & \\
\hline & Pseudolasius & risii * & native & 2021 & & & \\
\hline \multirow{31}{*}{$\begin{array}{l}\text { LEPTANILLINAE } \\
\text { MYRMICINAE }\end{array}$} & Leptanilla & macaoensis & native & 2017 & & & \\
\hline & Cardiocondyla & minutior & exotic & 2017 & - & $x$ & - \\
\hline & & wroughtonii * & tramp & 2021 & $x$ & - & - \\
\hline & Carebara & affinis * & native & 2021 & - & $x$ & $x$ \\
\hline & & capreola & native & 2003 & & & \\
\hline & & diversa & native & 1921 & - & - & $x$ \\
\hline & & diversa laotina & native & 2017 & & & \\
\hline & & melasolena* & native & 2021 & - & $x$ & $x$ \\
\hline & & sangi ${ }^{*}$ & native & 2021 & - & - & $x$ \\
\hline & & zengchengensis & native & 2017 & - & $x$ & $x$ \\
\hline & Crematogaster & binghamii * & native & 2021 & - & $x$ & - \\
\hline & & biroi & native & 1928 & & & \\
\hline & & dohrni & native & 1928 & & & \\
\hline & & ferrarii & native & 2017 & $x$ & $X$ & - \\
\hline & & macaoensis & native & 1928 & & & \\
\hline & & quadriruga & native & 2017 & - & $X$ & - \\
\hline & & rogenhoferi & native & 2017 & $x$ & - & - \\
\hline & Dilobocondyla & propotriangulata * & native & 2021 & $x$ & - & - \\
\hline & Mayriella & granulata * & native & 2021 & - & $x$ & - \\
\hline & Meranoplus & $\begin{array}{l}\text { sp. mo01 nr. } \\
\text { bicolor }\end{array}$ & native & 2017 & & & \\
\hline & Monomorium & chinense * & native & 2021 & $x$ & $X$ & $x$ \\
\hline & & intrudens * & tramp & 2021 & $x$ & $x$ & - \\
\hline & & floricola & tramp & 2017 & $x$ & $x$ & $x$ \\
\hline & & pharaonis & exotic & 2017 & - & $X$ & $X$ \\
\hline & & sp. psw-cn01 & native & 2021 & - & $x$ & - \\
\hline & Myrmecina & nomurai * & native & 2021 & - & $x$ & - \\
\hline & & sinensis & native & 2017 & & & \\
\hline & Pheidole & elongicephala* & native & 2021 & - & - & $x$ \\
\hline & & fervens & tramp & 2008 & - & $x$ & $x$ \\
\hline & & hongkongensis & native & 2008 & - & $x$ & - \\
\hline & & indica & tramp & 1928 & & & \\
\hline
\end{tabular}


Table 3. Cont.

\begin{tabular}{|c|c|c|c|c|c|c|c|}
\hline \multirow[t]{45}{*}{ Subfamily } & Genus & Species & Status & $\begin{array}{c}\text { Year of First } \\
\text { Published } \\
\text { Record }\end{array}$ & Arboreal & Ground & Subterranean \\
\hline & & megacephala & exotic & 2008 & $X$ & $x$ & $x$ \\
\hline & & ochracea & native & 2017 & - & $x$ & $x$ \\
\hline & & parva & tramp & 2008 & - & $x$ & $X$ \\
\hline & & pieli* & native & 2021 & - & $x$ & $x$ \\
\hline & & taipoana & native & 2008 & - & $x$ & $x$ \\
\hline & & tumida & native & 2017 & $x$ & $x$ & $x$ \\
\hline & & nodus & tramp & 2017 & - & $x$ & - \\
\hline & & vulgaris * & native & 2021 & - & $x$ & - \\
\hline & & zoceana * & native & 2021 & - & $x$ & - \\
\hline & & nr. ryukyuensis * & native & 2021 & - & - & $x$ \\
\hline & Recurvidris & recurvispinosa & native & 2017 & - & $x$ & - \\
\hline & Rotastruma & stenoceps * & native & 2021 & - & $x$ & - \\
\hline & Solenopsis & geminata & exotic & 1928 & & & \\
\hline & & invicta & exotic & 2006 & - & $x$ & - \\
\hline & & jacoti & native & 2017 & - & $x$ & $x$ \\
\hline & Strumigenys & emmae & exotic & 2017 & - & $x$ & - \\
\hline & & elegantula & native & 2020 & - & $x$ & - \\
\hline & & exilirhina & native & 2017 & - & $x$ & - \\
\hline & & feae & native & 2020 & - & $x$ & - \\
\hline & & membranifera & exotic & 1928 & - & $x$ & - \\
\hline & & minutula & native & 2017 & - & $x$ & - \\
\hline & & $\ddagger$ nepalensis & exotic & 2017 & - & $x$ & - \\
\hline & & sauteri & native & 2020 & - & $x$ & - \\
\hline & & subterranea & native & 2020 & - & - & $x$ \\
\hline & Syllophopsis & nr. cryptobia* & native & 2021 & - & - & $x$ \\
\hline & & $\begin{array}{l}\text { sp. mo01 nr } \\
\text { sechellensis }\end{array}$ & native? & 2017 & - & $X$ & $x$ \\
\hline & & sp. 1 BMW * & native & 2021 & - & $x$ & $x$ \\
\hline & & sp. 2 BMW* & native & 2021 & - & $x$ & - \\
\hline & Tetramorium & bicarinatum & tramp & 2017 & $x$ & $x$ & - \\
\hline & & indicum * & native & 2021 & $x$ & - & - \\
\hline & & insolens * & exotic & 2021 & - & $x$ & - \\
\hline & & kraepelini & tramp & 2017 & - & $x$ & $x$ \\
\hline & & lanuginosum & exotic & 1928 & - & $x$ & - \\
\hline & & nipponense & native & 2017 & $X$ & $X$ & - \\
\hline & & parvispinum & native & 2017 & & & \\
\hline & & simillimum & exotic & 2017 & & & \\
\hline & & tonganum * & exotic & 2021 & $x$ & - & - \\
\hline & & wroughtonii * & native & 2021 & - & $x$ & - \\
\hline & & nr. elisabethae * & native & 2021 & - & - & $x$ \\
\hline & & sp.1 obseum gr. & native & 2017 & - & $x$ & - \\
\hline & & sp. $2 \mathrm{JF}^{*}$ & native & 2021 & $x$ & - & - \\
\hline & & sp. $9 \mathrm{JF}^{*}$ & native & 2021 & - & - & $x$ \\
\hline & Vollenhovia & sp.1 BG * & native & 2021 & - & $X$ & - \\
\hline & & sp. 2 BG* & native & 2021 & - & $x$ & - \\
\hline \multirow[t]{4}{*}{ PONERINAE } & Anochetus & risii & native & 2017 & - & $x$ & - \\
\hline & Bothroponera & rubiginosa & native & 1928 & & & \\
\hline & Brachyponera & luteipes & tramp & 1928 & & & \\
\hline & & obscurans & native & 1928 & - & $x$ & $x$ \\
\hline
\end{tabular}


Table 3. Cont.

\begin{tabular}{|c|c|c|c|c|c|c|c|}
\hline \multirow[t]{16}{*}{ Subfamily } & Genus & Species & Status & $\begin{array}{c}\text { Year of First } \\
\text { Published } \\
\text { Record }\end{array}$ & Arboreal & Ground & Subterranean \\
\hline & Buniapone & amblyops * & native & 2021 & - & - & $x$ \\
\hline & Diacamma & sp. 1 & native & 2017 & $x$ & $x$ & - \\
\hline & Ectomomyrmex & annamitus * & native & 2021 & - & - & $X$ \\
\hline & & astutus & native & 2001 & & & \\
\hline & & leeuwenhoecki & native & 2017 & - & $x$ & - \\
\hline & Euponera & pilosior & native & 2017 & - & - & $x$ \\
\hline & & sharpi & native & 1928 & & & \\
\hline & Harpegnathos & venator & native & 2001 & - & $X$ & - \\
\hline & & venator rugosus & native & 1928 & & & \\
\hline & Hypoponera & exoecata & native & 2017 & - & $X$ & - \\
\hline & & sp. mo01 & native & 2017 & $x$ & $X$ & - \\
\hline & Leptogenys & chinensis & native & 2017 & & & \\
\hline & & peuqueti & native & 1928 & - & $X$ & - \\
\hline & Odontoponera & denticulata & native & 2017 & - & $x$ & - \\
\hline & Pseudoneoponera & rufipes & native & 1930 & - & $X$ & - \\
\hline \multirow[t]{2}{*}{ PROCERATIINAE } & Probolomyrmex & dabermanii* & native & 2021 & & & \\
\hline & Proceratium & $\underset{*}{\text { sp. cf. bruelheidei }}$ & native & 2021 & - & $x$ & - \\
\hline \multirow[t]{3}{*}{$\begin{array}{l}\text { PSEUDOMYR- } \\
\text { MICINAE }\end{array}$} & Tetraponera & allaborans & native & 2017 & & & \\
\hline & & binghami* & native & 2021 & $X$ & $x$ & - \\
\hline & & nitida* & native & 2021 & $x$ & - & - \\
\hline
\end{tabular}

\section{Ground}

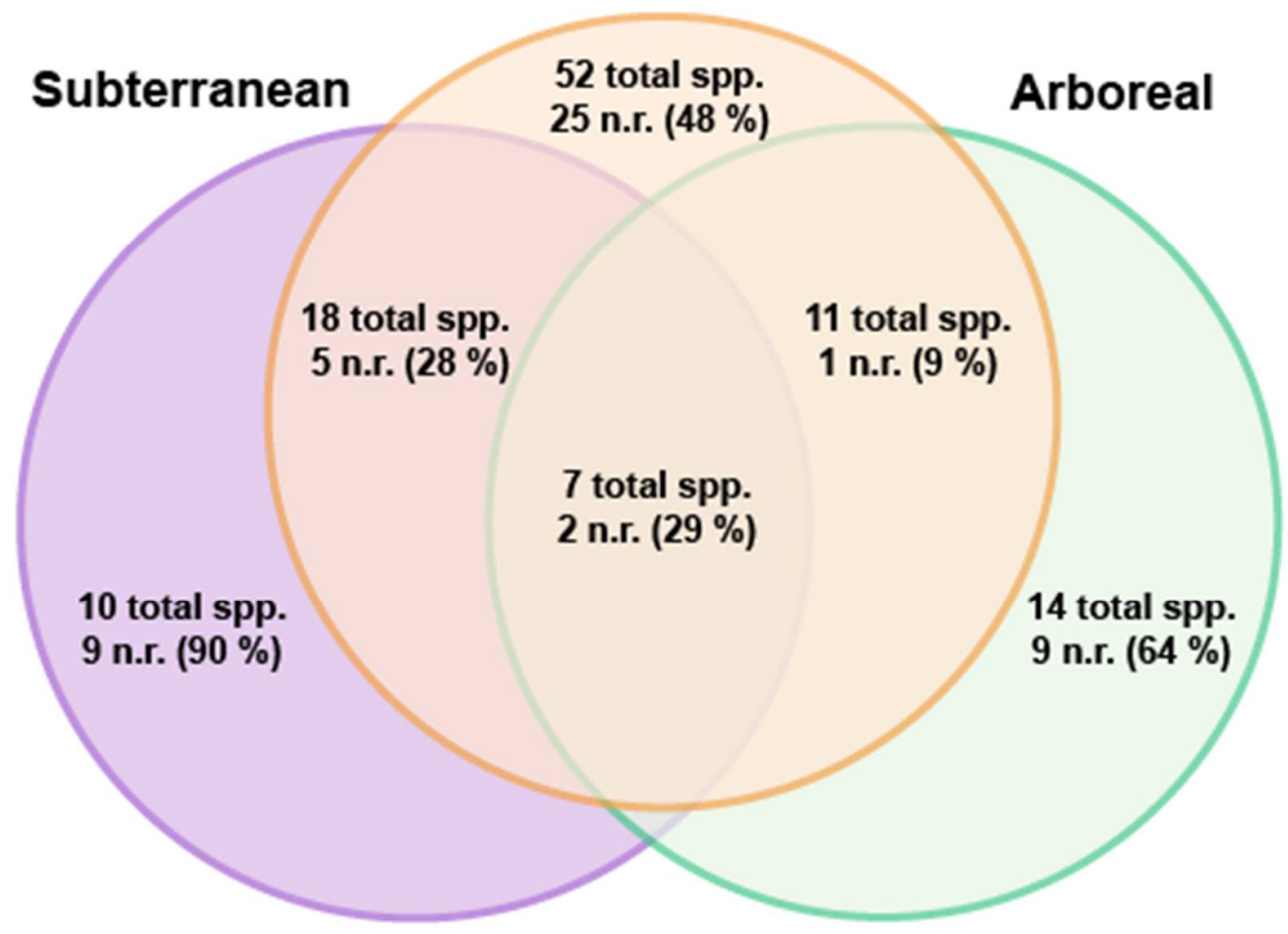

Figure 4. Venn diagram showing the total number of species (112 spp.) and new species records (51 n.r.) collected in each stratum during the 2019 survey. Numbers in parentheses represent the proportion of species collected within a stratum that are new records from the last 2017 checklist (Leong et al. 2017). Note that this figure does not include the four records added from specimens collected besides the main 2019 survey. 
At least five of the species collected during our 2019 survey, which belong to the genera Strumigenys, Syllophopsis, Tetramorium, and Vollenhovia, were considered potentially novel to science at the time of collection. We found three of the undescribed species in subterranean traps (i.e., Strumigenys subterranea, Syllophopsis nr. Cryptobia, and Tetramorium sp. 9 JF), one in leaf litter samples (i.e., Vollenhovia sp. 2 BG), and one in arboreal traps (i.e., Tetramorium sp. $2 \mathrm{JF}$ ).

Several of the new records have rarely been reported in the literature and represent extensions of their known range. First, we found workers of Dilobocondyla propotriangulata, an arboreal species described from Vietnam [197], at two different sites in Macao, which represents the third and fourth records of the species worldwide. Second, we found workers and a queen of Mayriella granulata, also described from Vietnam [198], which represents the first record of this species in China. Lastly, we found a worker of Probolomyrmex ( $P$. dammermani), a pantropical but rarely collected genus [199-201], which represents the first record of this species in China.

Before our survey, 14 tramp and 14 exotic species were known to occur in Macao. Here, we report four additional exotic species records: Brachymyrmex patagonicus, Plagiolepis alluaudi, Tetramorium insolens, and T. tonganum. We also report three additional tramp species records: Cardiocondyla wroughtonii, Iridomyrmex sp. anceps complex, and Monomorium intrudens. Moreover, we report new localities in Macao for several exotic species: Anoplolepis gracilipes, Cardiocondyla minutior, Monomorium pharaonis, Ooceraea biroi, Paratrechina longicornis, Pheidole megacephala, Solenopsis invicta, Strumigenys emmae, S. membranifera, S. nepalensis, and Tetramorium lanuginosum.

Nevertheless, despite achieving a high sampling coverage (i.e., between 80 to $98 \%$ depending on the method), species accumulation curves indicate that further sampling should uncover several more species on Coloane Island (Figure 5, Table 4). Indeed, estimates predict that each sampling method could collect from 2 to 25 additional species each.

Table 4. Summary of the species richness collected, the sampling completeness, and the richness estimates for each sampling method used during the sampling done in Coloane in 2019.

\begin{tabular}{lccc}
\hline \multicolumn{1}{c}{ Sampling Method } & Observed Richness & $\begin{array}{c}\text { Sampling } \\
\text { Completeness }\end{array}$ & Estimated Richness \\
\hline Arboreal Bait & 26 & 0.98 & 28.49 \\
Ground Bait & 42 & 0.95 & 49.17 \\
Ground Nest & 21 & 0.80 & 41.14 \\
Leaf Litter Sampling & 59 & 0.93 & 64.70 \\
(Standardized area) & & & 88.80 \\
Leaf Litter Sampling & 64 & 0.86 & 56.25 \\
(Species pool) & 35 & 0.88 & \\
Subterranean trap & & & \\
\hline
\end{tabular}

We identified 112 studies, representing 109 cities, that focused on ants within urban environments (Figure 1, Table 1). Among those, 23 studies provided species checklists, while 88 represented ecological surveys. The studies were unevenly distributed across biogeographic regions. The highest numbers were from North America $(n=41)$, Asia ( $n=34)$, Europe $(n=24)$, and Central and South America $(n=21)$, whereas Australia $(n=6)$ and Africa $(n=5)$ had the lowest number of studies. Although Asia had the second highest number of studies, most of these originated from temperate regions, with only eight studies $(23.5 \%)$ conducted within tropical or subtropical regions. 


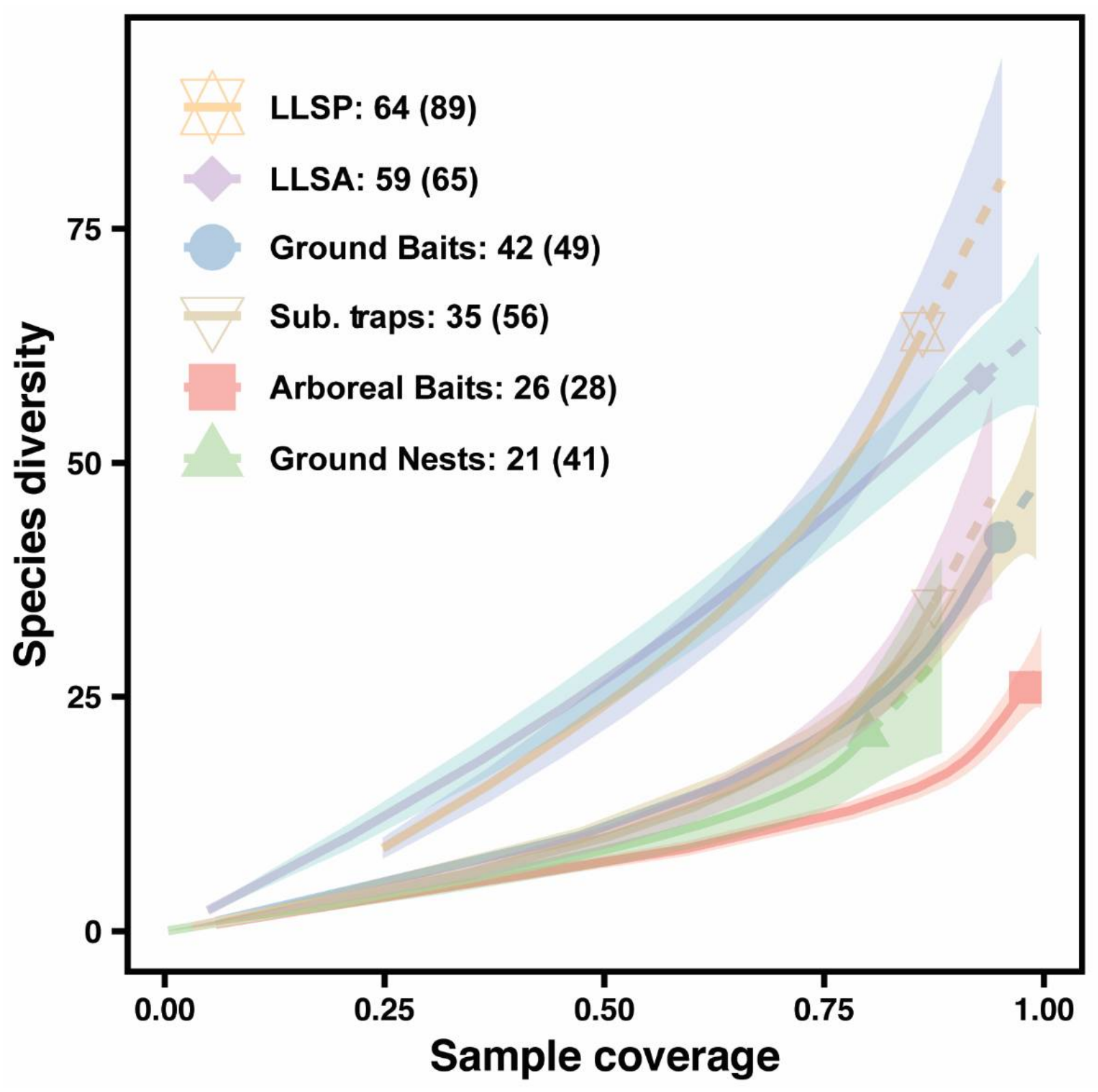

Figure 5. Species diversity in relation to sampling coverage for each standardized technique used in Macao in 2019. Values in the legend represent the number of species collected, and, in brackets, the estimated number of species that would be collected by this method if sampling coverage would reach $100 \%$ (asymptotic estimates of order $q=0$ obtained using the function ChaoRichness in the package iNEXT). The dotted line shows the extrapolation for the predicted number of new records if sampling completeness would reach $100 \%$ (i.e., a value of 1.00 on the graph). Shaded areas represent the $95 \%$ confidence intervals of each curve. Calculation method used species incidence frequency. Leaf litter samples were considered as four units of $1 \mathrm{~m}^{2}$ per Winkler sack (which pooled $4 \mathrm{~m}^{2}$ of leaf litter). Abbreviations are (LLSP) leaf litter extraction with the species pool technique and (LLSA) leaf litter extraction with the standard area technique.

\section{Discussion}

A common perception of urban biodiversity is that it is characterized by low species richness and dominated by exotic species [12]. This perception may be induced by the excess of local scale studies ( $\alpha$ diversity) compared to the limited number of studies at larger scale ( $\gamma$ diversity) encompassing the full diversity encountered within of a city (Table 1). Here, our results contrast with the former assumption but agree with the latter. Indeed, we found that Macao hosts a diverse ant fauna, but that a high number of that fauna consists of exotic and tramp species. 
Macao's ant fauna presents one the highest known ant richness reported for an urban region (Table 1). Our results indicate that, while there are few comprehensive studies for tropical regions-most studies on urban ants have been conducted within temperate regions where species diversity is usually much lower than in tropical and subtropical regions [202] - several cities, including Macao, offer potential conservation values for ants. For instance, a study limited to the botanical garden of Bogor (Java), a small green oasis within an urban area, captured 216 ant species [69]. Similarly, ecological studies in Abidjan (Ivory Coast, 176 species) and Uberlândia (Brazil, 143 species), among others, also presented high ant species richness [62,155]. Altogether, these results highlight the potential conservation value of urban habitats, but also their potential to increase the biogeographic and taxonomic knowledge on ants. Indeed, contrary to most natural habitats, urban habitats are characterized by their easy access, which facilitates continuous and thorough sampling. As for tropical forests, the vertical stratification of ants within cities does exist, and, as a result, researchers should consider diversifying their sampling approach to include subterranean and arboreal communities as well as epigeic ants.

Ant assemblages are known to be highly structured along a vertical gradient ranging from the top soil layer (first $50 \mathrm{~cm}$ ) to the tree canopy [203,204], but such stratification had not been shown for urban environments prior to this study. Our results show that ignoring these strata may lead to an underestimation of species richness estimates. Indeed, although most of the new species records were collected within the ground stratum, we found several previously unrecorded arboreal and subterranean specialists. In particular, of the 35 species collected with our subterranean trapping, 10 were found only within that stratum, nine of which were new records, and three represented undescribed species. Remarkably, this parallels the results of previous surveys focusing on multiple strata but conducted within natural ecosystems [205]. For instance, in Ecuador, Wilkie and collaborators collected 47 species in subterranean probes, nine of which were exclusively subterranean, and two were undescribed [205]. It is also worth noting that 14 species collected during the 2019 survey were unique to the arboreal stratum, nine of which were new records, and one was an undescribed species. This shows the importance of using sampling methods targeting the ant communities of all vertical strata, instead of focusing solely on ants found within a single stratum as is commonly done in urban studies [52].

Other methods captured fewer novel records, but, nonetheless, provided ecological and biogeographic information for a wide range of species. For instance, ground baits often collected large series of workers, including multiple worker castes for polymorphic species, which is often essential for their identification. As for ground nests, they had the lowest rate of capture, but provided important and rarely collected sociometric data, including new colony size information for seven species (Guénard, unpublished). Since we still lack information on the sociometry of most ant species [206,207], ground nests proved especially useful in collecting this valuable data. However, it is worth noting that the colonization rate of the ground nests, with $3 \%$, was neatly inferior to the rate observed in previous studies using similar devices (e.g., 8\% in [180]), or from other urban areas [141]. While the type of nests may be suboptimal for the ant community present in Macao, it is surprising that they were not more heavily exploited by ants, especially because urban habitats are usually characterized by limited nesting resources [141]. Perhaps the subtropical conditions characterized by heavy rains prevented the establishment of ants. Indeed, several nests had their openings clogged with mud and some had their inner cavities filled with fungal growths. Just as with temperate regions [141], the testing and deployment of different artificial nest apparatuses may represent an interesting opportunity to census urban ants and their sociometric characteristics. 
Even though we used an exhaustive sampling approach, and our results substantially increased our knowledge on Macanese ants, species accumulation curves indicate a substantial number of unrecorded species to be collected using a similar methodology (Figure 4). This is supported by the several species previously recorded within Macao, but not collected in this study (Table 2). Previous studies conducted within more natural or relatively undisturbed habitats showed that achieving an exhaustive sampling of local diversity represents a challenging task [125,208,209]. After two separate survey programs ([53], this study), our results confirm this is similar for urban areas. Furthermore, other sampling methods not used here could have been added, such as pitfall traps to collect larger ground-dwelling ants [210], canopy fogging to collect arboreal species [211], Malaise traps to collect alates [212], and multiple soil sampling methods to collect subterranean ants [50]. Thus, while our study contributes to a better understanding of ant species richness and composition in Macao, it represents a steppingstone and not a final outcome, with future sampling likely to provide additional new records, and potentially more undescribed species.

Despite the geographic limitations of our sampling, being restricted to Coloane island, this allowed us to considerably increase the list of Macanese ant species. These new records highlight the potential for urban forest fragments and other urban habitats to maintain a significant portion of ant diversity. Similar examples can be found in Asia, such as in in Bogor and Singapore $[69,102]$. Likewise, Hong Kong harbors a high ant richness (Lee et al. in press, Guénard unpublished), with numerous new records and species recently reported (e.g., [55,192]). Additionally, comparative studies focusing on old growth and secondary forests in both cities also reported no significant difference in ant richness between the types of forests $([213,214]$, Nooten et al. submitted). As such, past studies and the current one should motivate the conservation of forest patches in and around urban matrices in Asia, whether they are primary or secondary.

Nevertheless, a key difference between disturbed and undisturbed habitats lies within their species composition instead of in the number of species they harbor, and a significant part of Macao's fauna consists of non-native species. The previous survey reported several new records of exotic species in Macao [53], which are here completed with the additions of four exotic and three tramp species (Figure 1), totaling in 18 exotic species and representing $11.5 \%$ of the Macanese ant fauna. The most notable newly reported exotic is Brachymyrmex patagonicus, a major pest in south-east USA [215]. This represents the second record of $B$. patagonicus in continental Asia, with the first report from Hong Kong [216]. Its presence in Macao is worrisome, and clear plans to determine the extent of its distribution, with programs to destroy established populations, should be developed quickly. We also report the spread of several alien and potentially harmful species. We found the three exotic species Anoplolepis gracilipes, Monomorium pharaonis, and Paratrechina longicornis in five, seven, and six forested sites, respectively. They can, thus, establish populations and persist in forested habitats, where their effects on native ants are unknown. Through our standardized sampling, we also found the notorious invasive species Solenopsis invicta and Pheidole megacephala but, interestingly, rarely found it in Coloane's forested sites. Despite finding several workers and queens of S. invicta through hand collection in open and urban habitats, we found this species in only one forested site near a hiking trail: one individual was found in a leaf litter sample and several workers colonized two ground baits at that site. This reflects previous findings that the distribution of $S$. invicta is mainly restricted to disturbed habitats [217-219]. Similarly, while we found a high abundance of workers of $P$. megacephala on one golf course, we collected only two individuals in forested sites. For both of these species, notorious for their destructive impacts on native communities [220-222], this would indicate that, for now, they are mainly restricted to more open and disturbed habitats. This suggests that forested habitats may help preserve local biodiversity while simultaneously limiting the distribution of some invasive ant species, reflecting results from Hong Kong and Hainan, where less disturbed habitats harbored relatively fewer exotic species than did more disturbed ones [223]. 
Nonetheless, the occurrence of exotic species in Macao is high. In comparison, the checklist of the ants of Yunnan reports that only $2 \%$ of its species are introduced [224], a proportion 5.75 times lower than in Macao. Based on current knowledge, Macao appears to have one of the highest numbers and proportions of exotic species encountered within cities (Table 1). Alas, we also report the presence of 17 tramp species, some of which may very well be introduced, as our biogeographic understanding and the region of origin for several species remains limited; thus, the overall number may be even higher. The high proportion of exotic and tramp species in Macao supports the hypothesis that coastal cities act as gateways for the introduction of exotic species through high propagule pressure [225]. In addition, since the occurrence of non-native species is an indicator of reduced ecological integrity [226], the high proportion of non-native species we found in Macao suggests these habitats have suffered substantial damage. It is, thus, crucial to make periodical biodiversity surveys in Macao and other cities to monitor their habitats' health through time, as well as to identify new arrivals of exotics and prevent their further spread.

An historic baseline is lacking for Macao's ant assemblages, but we suspect there may be substantial differences compared to the ant assemblages before urbanization. Indeed, several genera known to occur in southern China and within neighboring cities of the Greater Bay Area, such as Hong Kong, are missing from Macao. These include Aenictus and Dorylus army ants, Discothyrea, Odontomachus, Ponera, and weaver ants (Oecophylla smaragdina). The absence of army ants in Coloane (except O. biroi, an exotic species), such as species of Aenictus and Dorylus, may be explained by the morphology of the queen caste in these genera: they lack wings and, thus, cannot disperse by flight [227]. As such, if these ants disappeared from Coloane during a disturbance event, we may expect that it would be arduous for these species to recolonize the island. Of course, native army ant species may have been absent from Coloane throughout Macao's urbanization history due to its insularity or of its small size ([228], but see [229]). However, the presence of native army ants on several of Hong Kong' islands-for example, the Aenictus species found on Lamma Island $\left(13.55 \mathrm{~km}^{2}\right.$, François Brassard pers. obs.)—suggests they could have been extirpated from Coloane Island and then failed to recolonize. More puzzling is the absence of genera such as Discothyrea, Odontomachus, Oecophylla, and Ponera. Small and relatively uncommon species of Discothyrea and Ponera may have escaped our sampling or may be especially sensitive to disturbance. However, for unknown reasons, large and conspicuous species such as Odontomachus and especially Oecophylla, frequently encountered on forest edges or in disturbed habitats within Hong Kong, are probably truly absent from the island.

\section{Conclusions}

In summary, this study highlights the importance of conducting holistic biodiversity surveys in cities to discover new records as well as potential new species for science, and to monitor the introduction of new exotic species. Our results suggest that forest patches in cities can harbor a diverse ant fauna and may have a significant conservation value. However, exhaustive ant diversity surveys in cities are rare, and are often based on incomplete sampling approaches. Thus, until the completion of several more surveys in cities around the world, particularly within tropical regions, a clear understanding of how urban environments may act as biodiversity refuges and gateways for exotic species will be lacking. As such, we advocate that conservation management practices should implement regular biodiversity surveys using an exhaustive sampling approach in urban regions worldwide. Whenever possible, we also recommend that urban biodiversity assessments be combined with surveys done in less urbanized habitats nearby to compare the diversity and composition of each habitat.

Supplementary Materials: The following are available online at https://www.mdpi.com/article/10 $.3390 /$ d13080358/s1. Figure S1: Map of Coloane showing the 21 sites sampled in the 2019 survey. White dots mark sites where the full protocol was done (i.e., standardized and species pool leaf litter extractions, ground baiting, ground nests, subterranean traps, and arboreal traps), whereas grey dots mark preliminary sites where only ground baiting and leaf litter extractions were done. Hand 
collection was also opportunistically used at each site. Figure S2: Design of a $20 \times 20 \mathrm{~m}$ sampling plot. Each of the $1 \times 1 \mathrm{~m}$ quadrats where subterranean traps and leaf litter extraction (standardized area) was performed were placed at a corner of the plot. Black dots show the emplacement of nest bundles. For the species pool leaf litter extraction, 12 microhabitats were sampled within the light gray area. For the arboreal baiting protocol, four trees measuring a minimum of $5 \mathrm{~m}$ height were sampled within the grey area. Table S1: List of the localities of each sampling sites, their associated number, and their geolocation. The date refers to the first sampling event made at a site, which corresponded to the leaf litter extraction and placement of subterranean traps. Sampling protocols are defined as follows: the letter $(\mathrm{P})$ signifies a partial sampling protocol (i.e., leaf litter extraction, ground baiting, and hand collection), whereas the letter $(\mathrm{F})$ signifies a full protocol (i.e., leaf litter extraction, ground baiting, ground nests, subterranean traps, arboreal traps, and hand collection). Table S2: Sociometry data collected using ground nests. Macao species: material examined.

Author Contributions: Conceptualization, F.B. and B.G.; methodology, F.B. and B.G.; validation, F.B. and B.G.; formal analysis, F.B.; investigation, F.B.; resources, B.G., H.-H.C., and C.-M.L.; data curation, F.B. and B.G.; writing—original draft preparation, F.B.; writing-review and editing, F.B., B.G., C.-M.L., and H.-H.C.; visualization, F.B.; supervision, B.G.; project administration, B.G.; funding acquisition, B.G. All authors have read and agreed to the published version of the manuscript.

Funding: F.B. was supported by the Instituto para os Assuntos Municipais, Macao SAR, China, CML was supported by the Macao Foundation and the Direcção dos Serviços do Ensino Superior, Macao SAR, China, and CML and FB were supported by The University of Hong Kong, Hong Kong SAR, China.

Institutional Review Board Statement: Ethical review and approval were waived for this study, due to our work being conducted on invertebrates.

Data Availability Statement: The data presented in this study are available in tables within the main text and within the supplementary material section.

Acknowledgments: We thank Jason L. Williams and Georg Fischer for their help with the identification of species within the genera Nylanderia and Carebara, respectively. We acknowledge that the images we shared with these specialists are not optimal for identification and, as such, if some misidentifications are later revealed, these errors should be considered our own, not theirs. We thank Siu Yiu for her help conducting fieldwork, as well as with sorting, mounting, and imaging specimens. We thank Carly McGregor for her help conducting fieldwork. We thank Sabine Nooten for her help producing species accumulation curves. We also thank the Environmental Protection Bureau, Caesars Golf Macau, and the Macau Golf and Country Club for allowing us to sample on their premises.

Conflicts of Interest: The authors declare no conflict of interest. The funders had no role in the design of the study; in the collection, analyses, or interpretation of data; in the writing of the manuscript, or in the decision to publish the results.

\section{Appendix A}

The appendix shows all species for which we had specimens within the IBBL collection. These are shown in lateral, dorsal, and face view. Within the figure, we include a map of south-east Asia showing the distribution of the species. We colored polygons according to whether a species was recorded as a native or exotic species, or unrecorded for a specific region. Note that we could not use the label tramp because most studies do not distinguish beyond native or exotic. We also include an inset map showing where the species was found in Macao. Black triangles indicate collection locations made during the 2019 survey, whereas white dots indicate collection locations not done during the survey. 


\section{Appendix A.1 AMBLYOPONINAE}

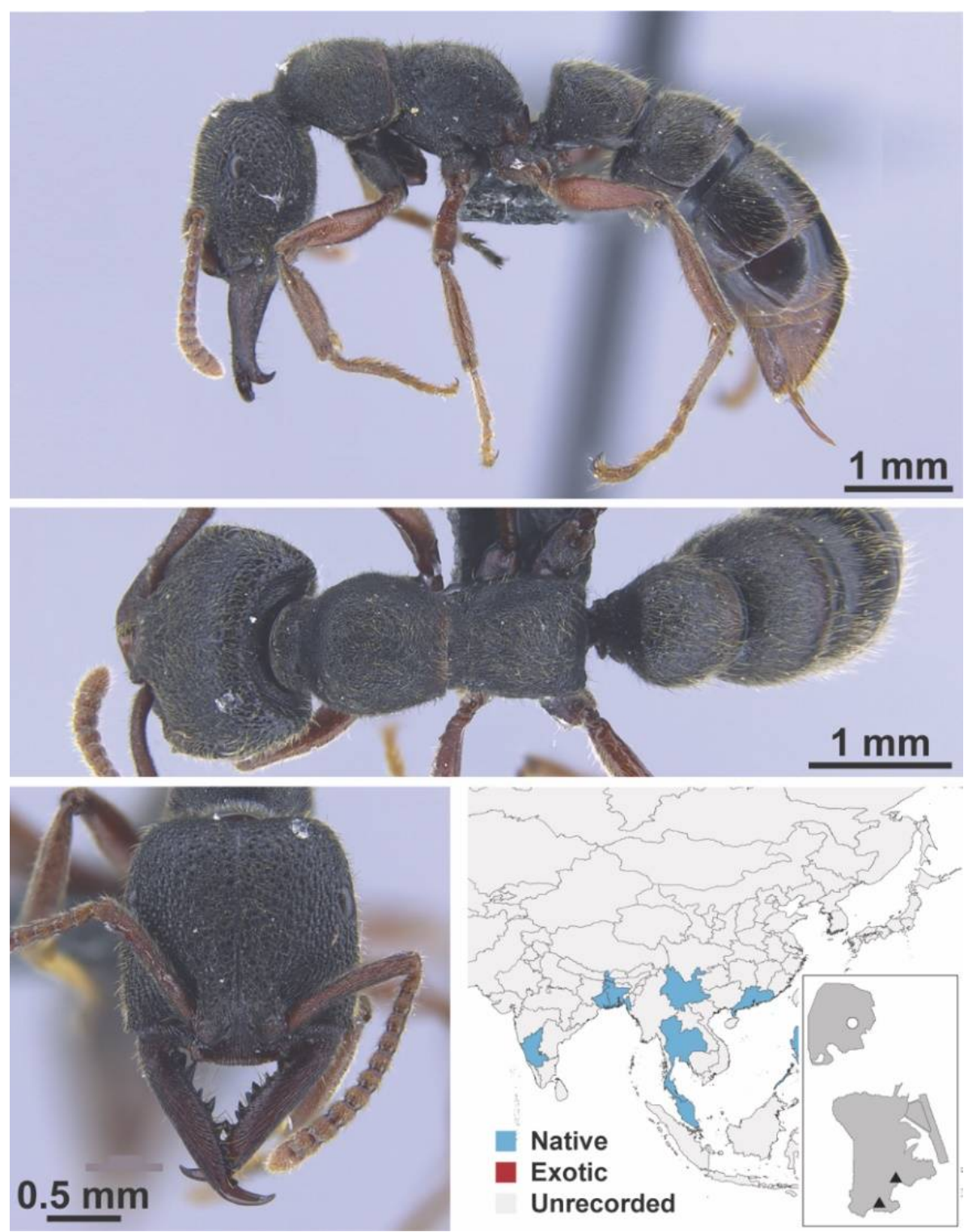

Figure A1. Stigmatomma rothneyi Forel, 1900 worker (MAC_S11_LLSA_Sp.2, IBBL). 


\section{Appendix A.2 DOLICHODERINAE}
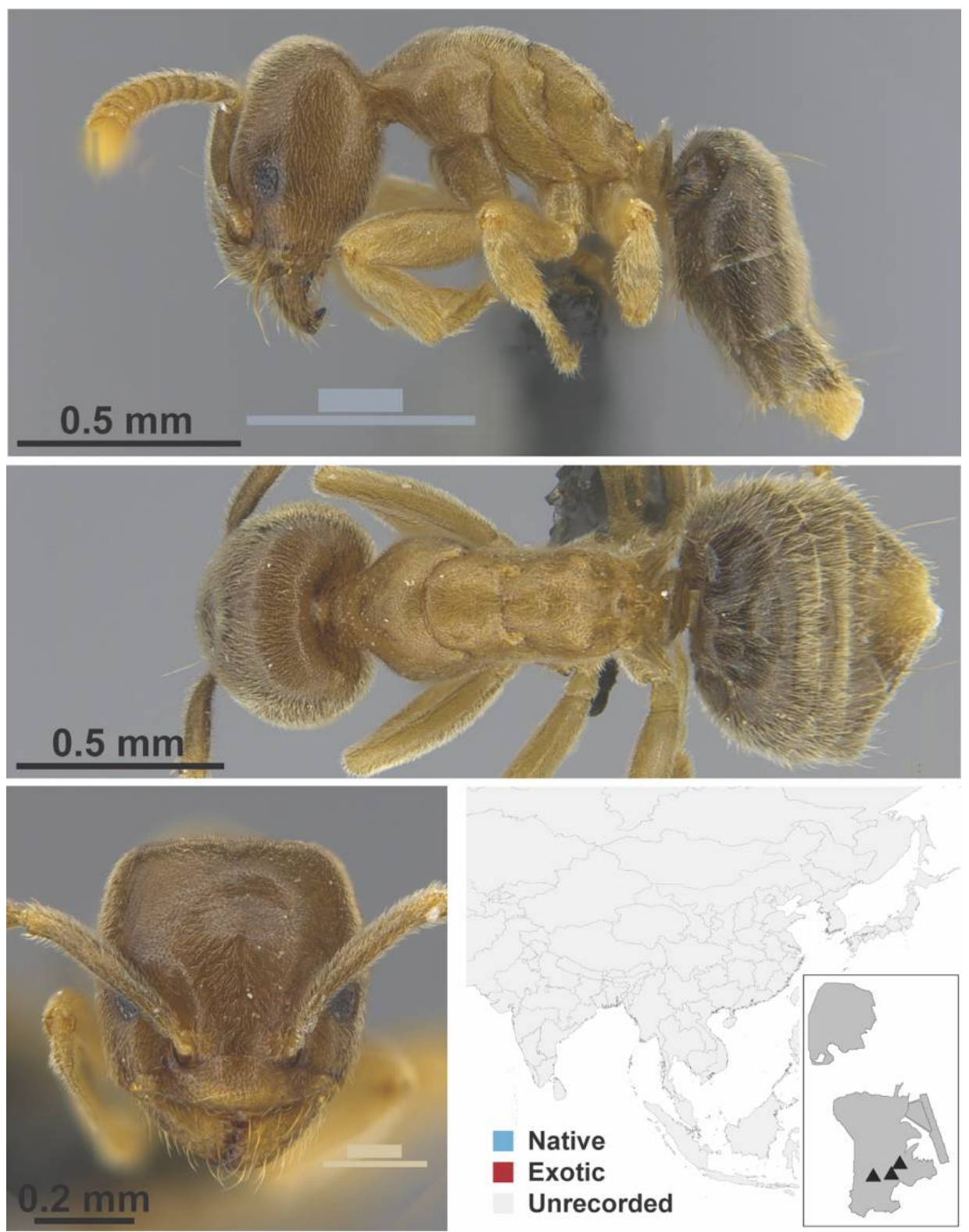

Figure A2. Chronoxenus morpho 1 worker (MAC_S14_LLSP, IBBL). 

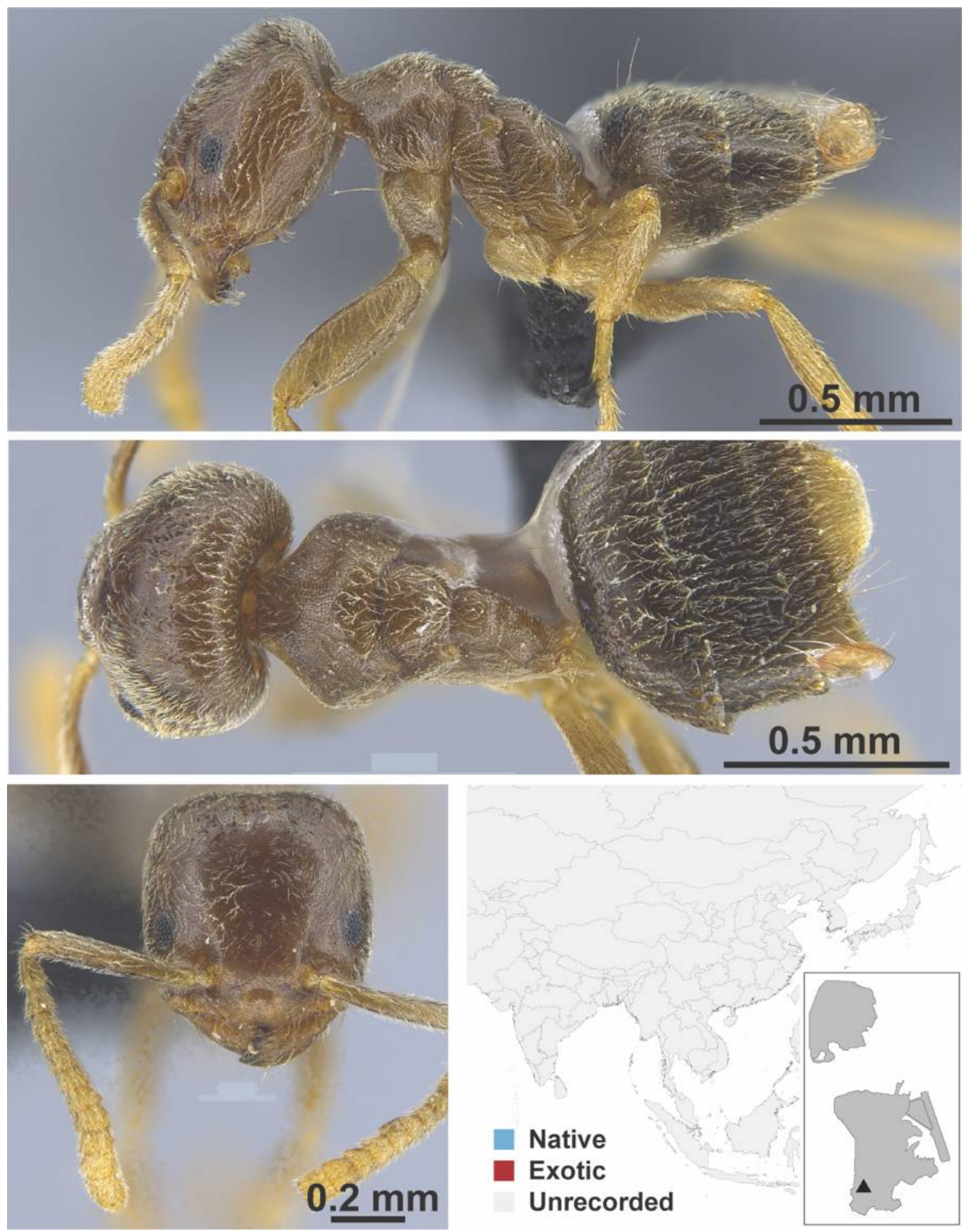

Figure A3. Chronoxenus morpho 2 worker (MAC_S21_q2_50_sp.2, IBBL). 


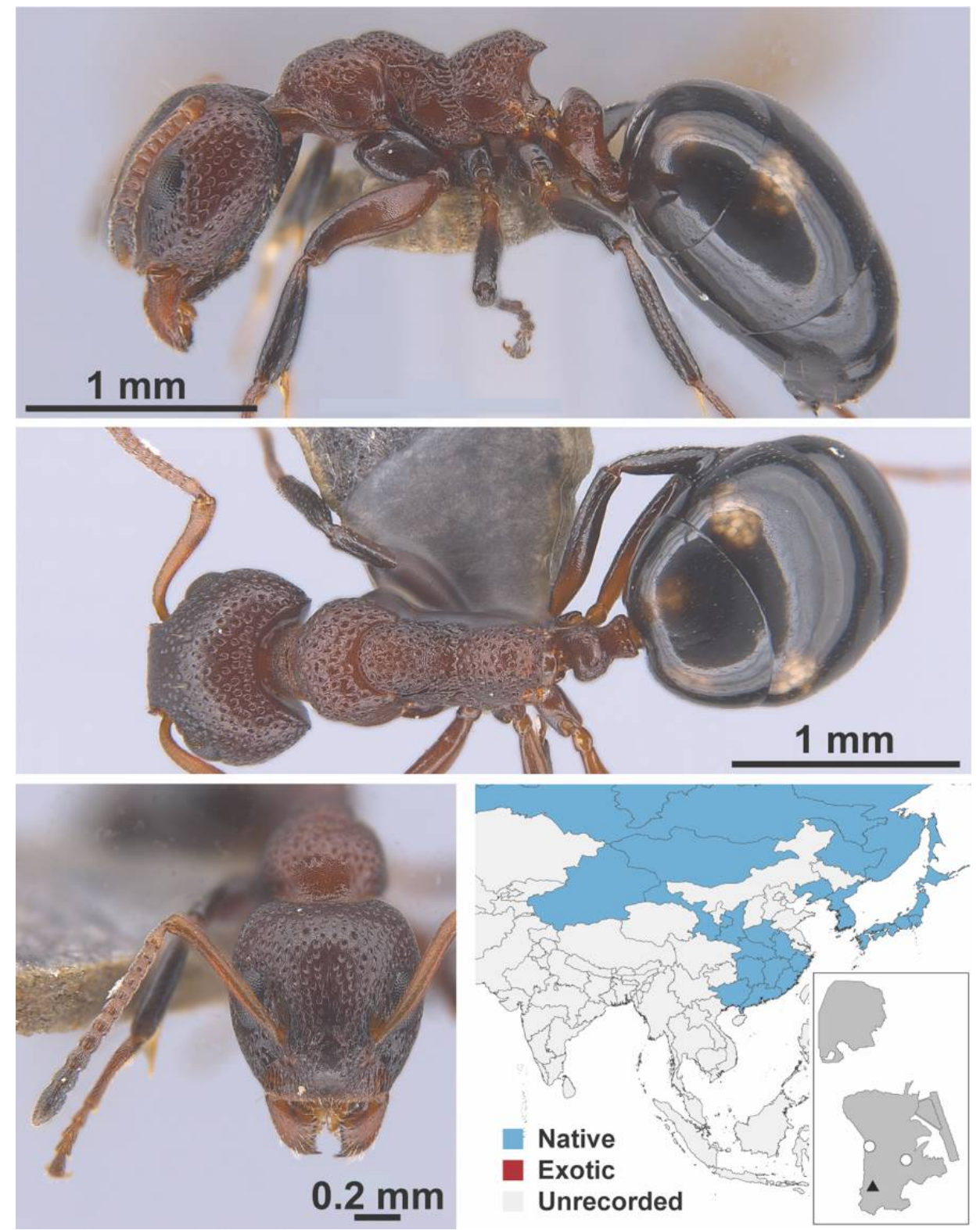

Figure A4. Dolichoderus nr. sibiricus Emery, 1889 worker (FB19279, IBBL). 

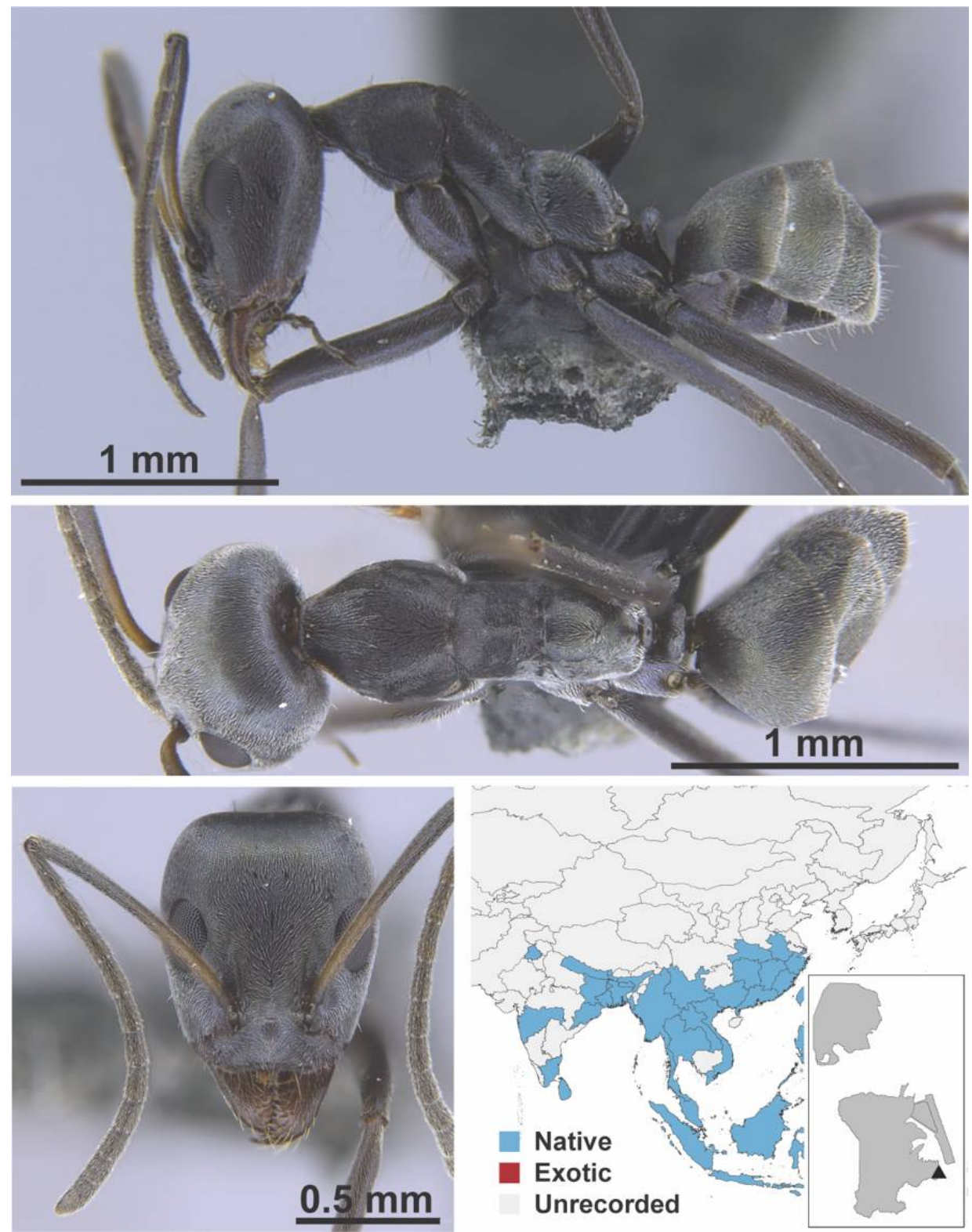

Figure A5. Iridomyrmex anceps grp. Roger, 1863 worker (FB19166, IBBL). 

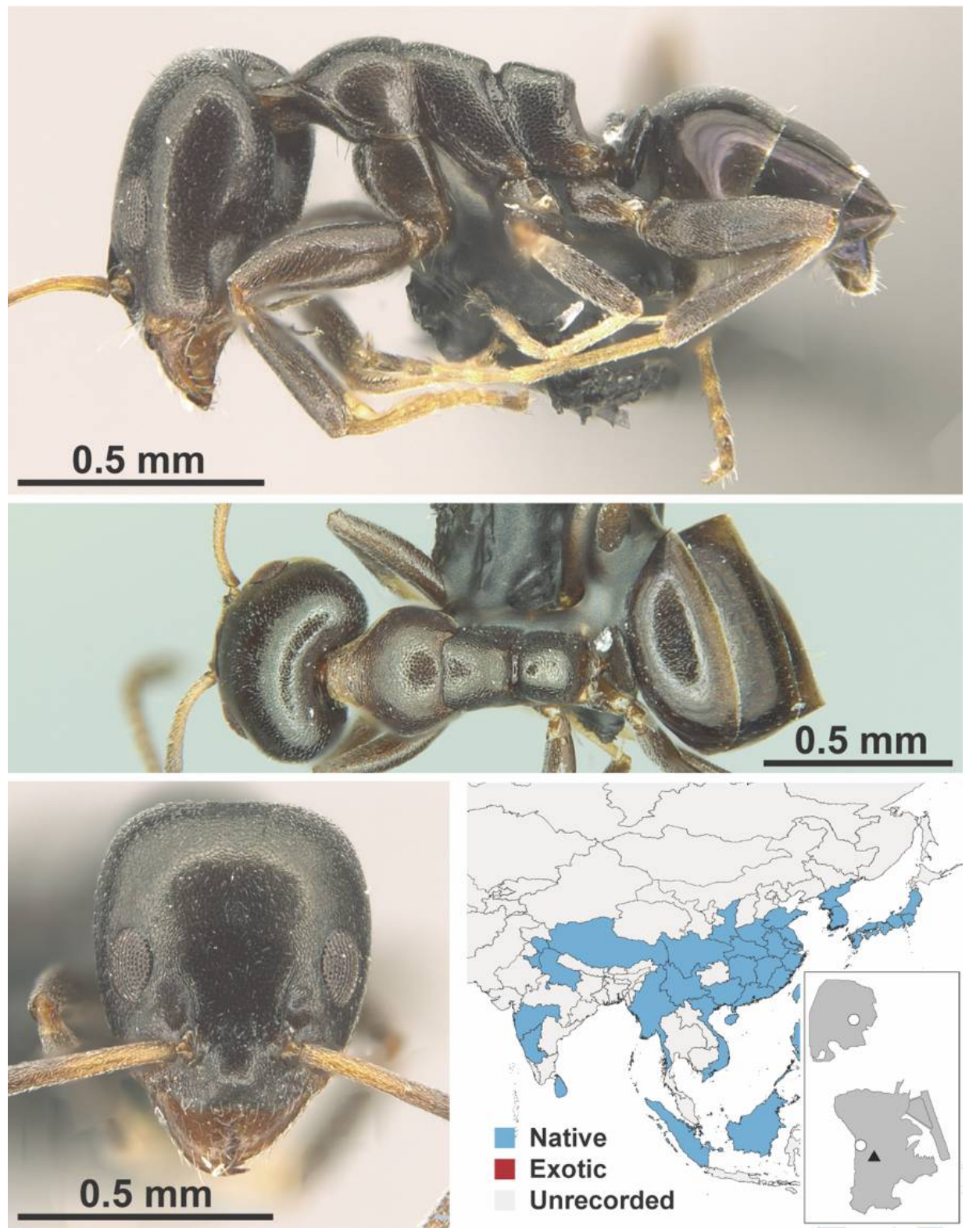

Figure A6. Ochetellus glaber Mayr, 1862 worker (MAC_S19_LLSP_sp.5, IBBL). 

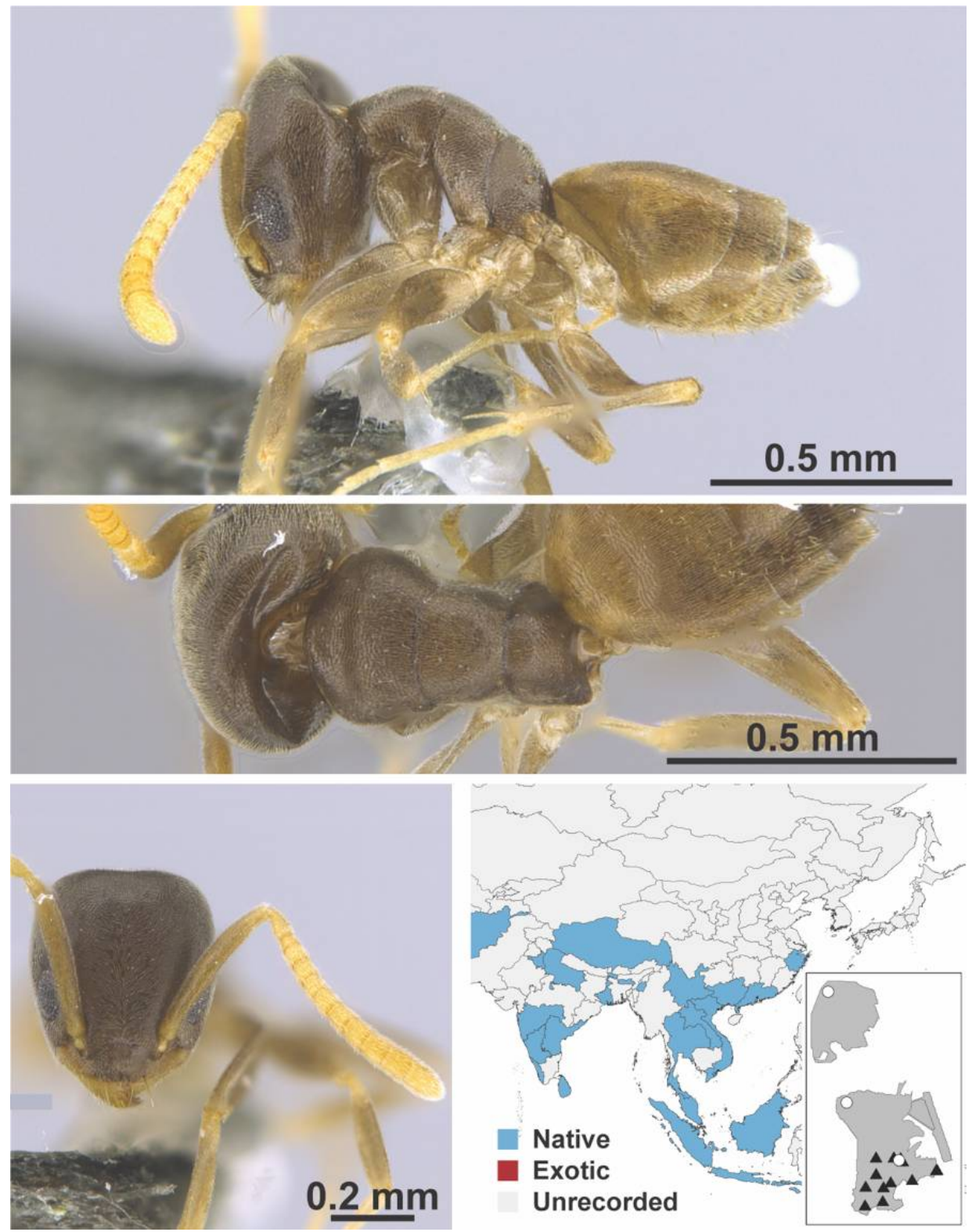

Figure A7. Tapinoma indicum Forel, 1895 worker (MAC_S01_LLSP_Sp.9, IBBL). 

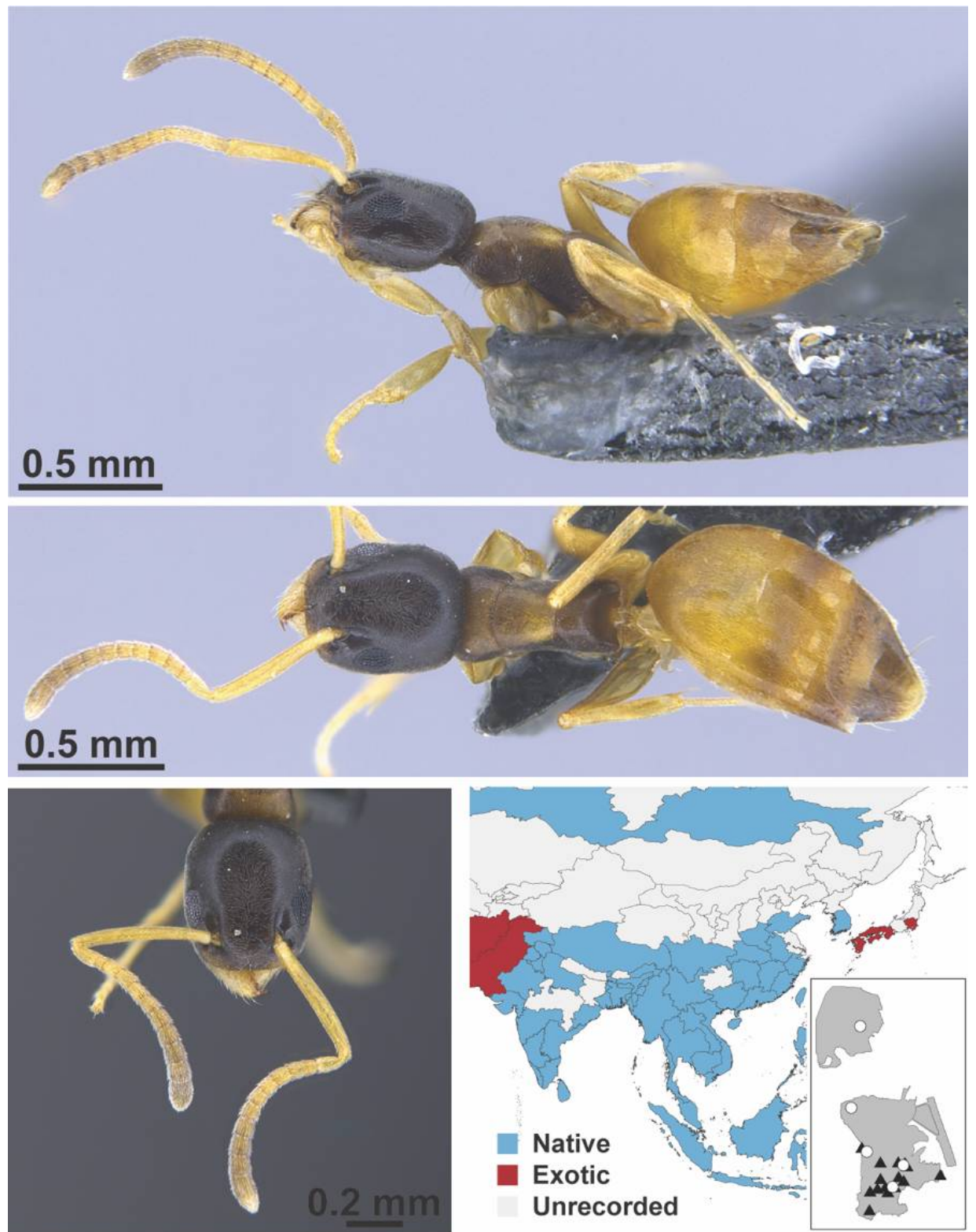

Figure A8. Tapinoma melanocephalum Fabricius, 1793 worker (MAC_S01_LLSP_Sp.6, IBBL). 

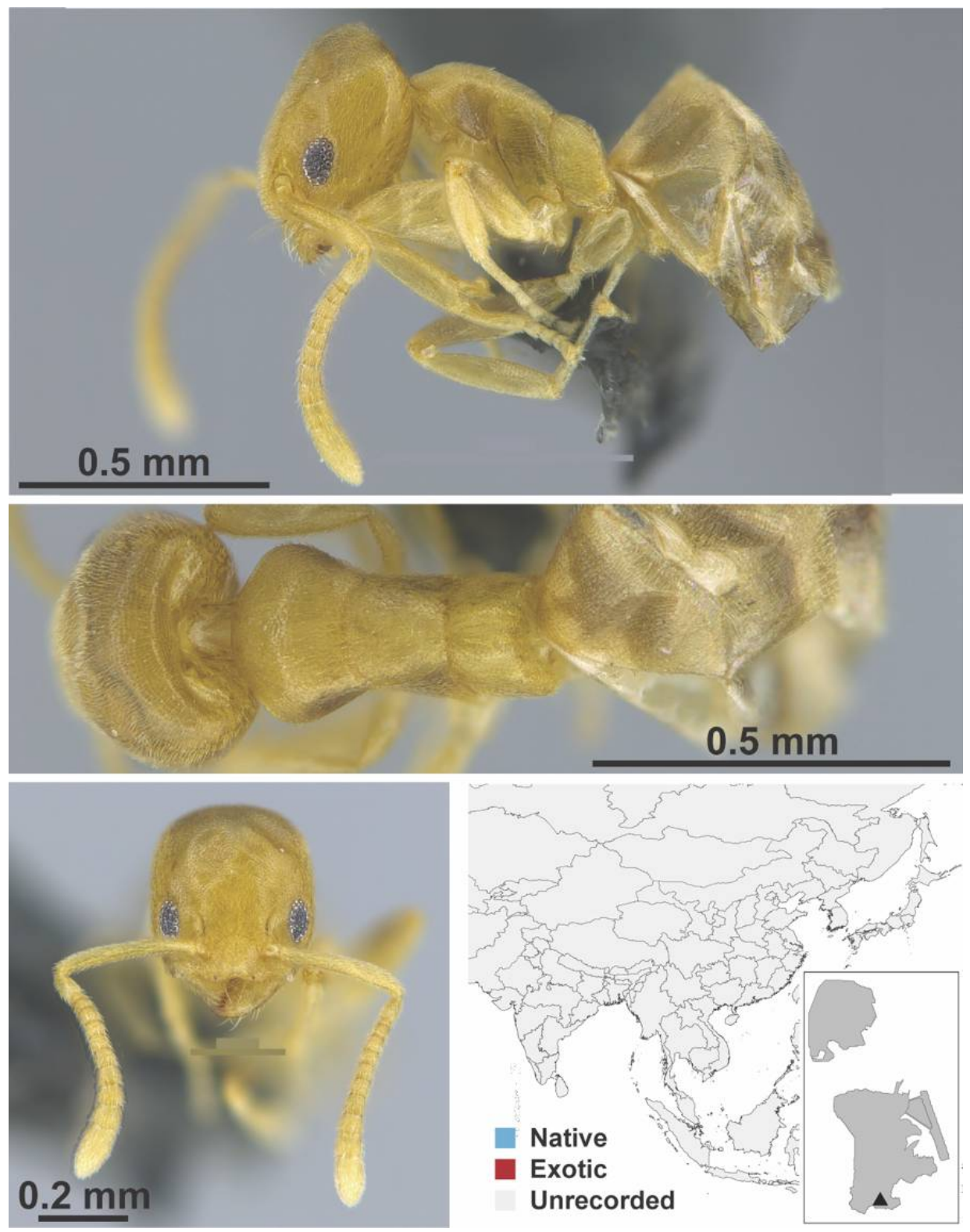

Figure A9. Tapinoma sp. 1 FB worker (MAC_S11_T4_1m_sp.2, IBBL). 


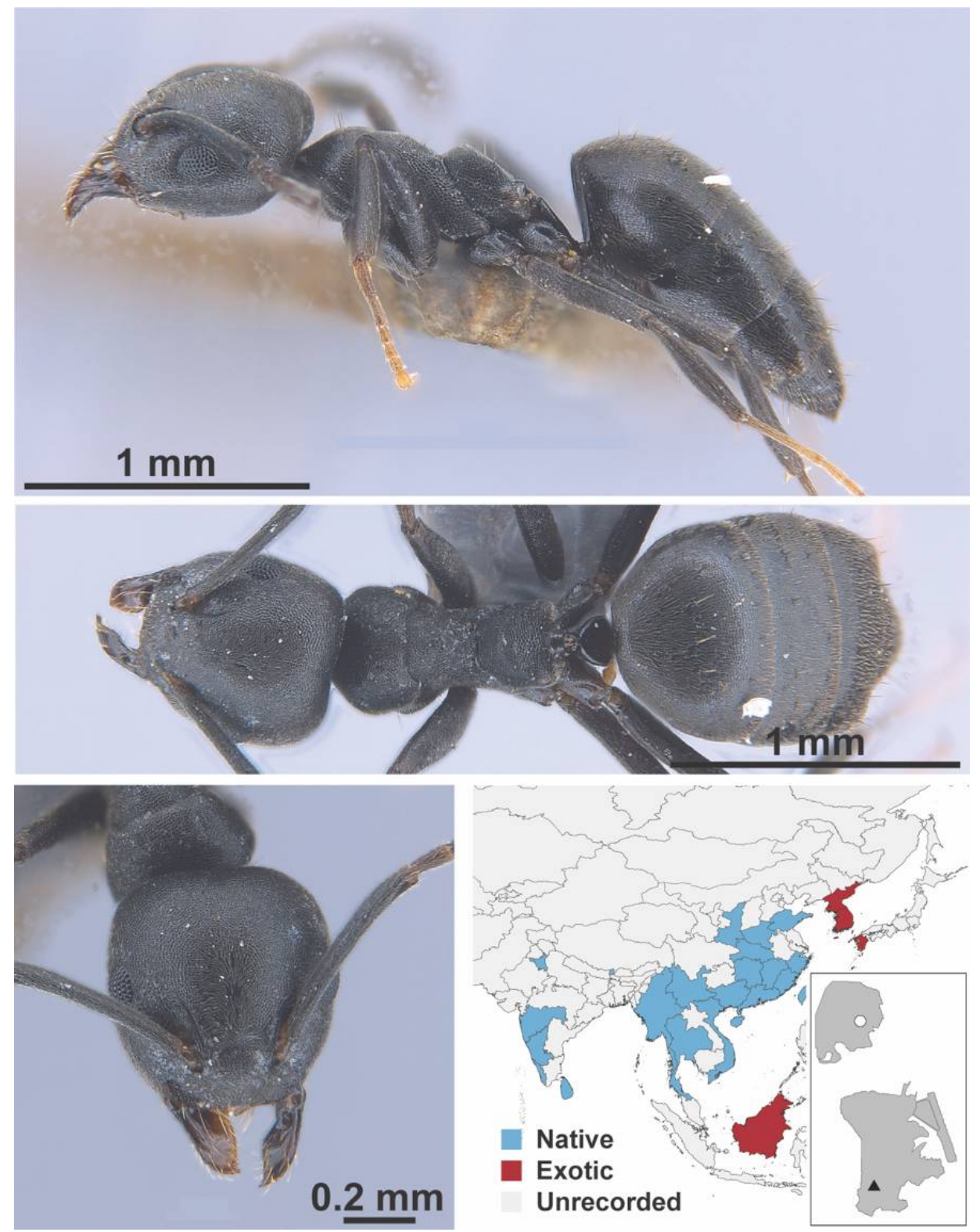

Figure A10. Technomyrmex brunneus Forel, 1895 worker (FB19281, IBBL). 

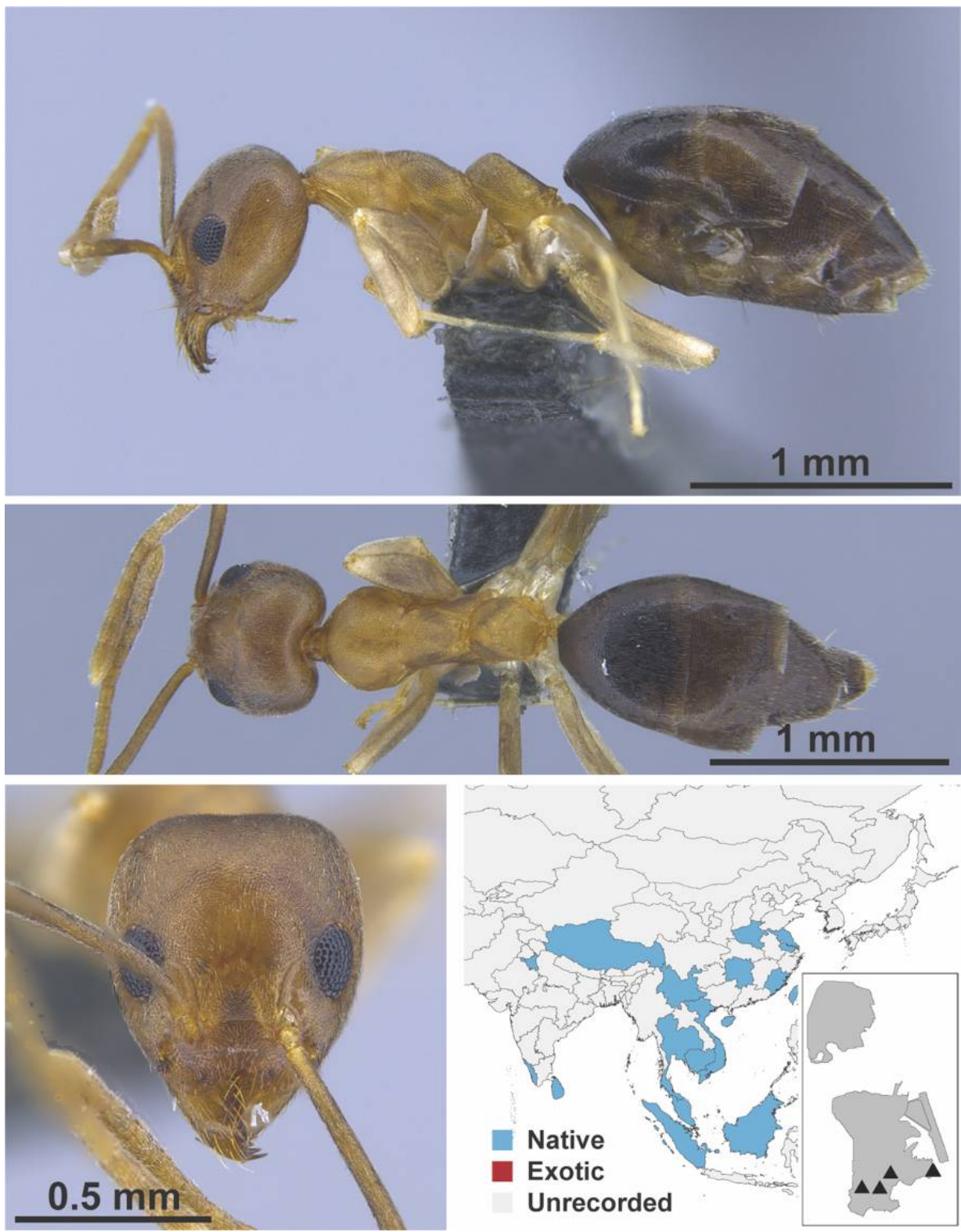

Figure A11. Technomyrmex horni Forel, 1912 worker (MAC_S01_LLSP_Sp.2, IBBL). 
Appendix A.3 DORYLINAE

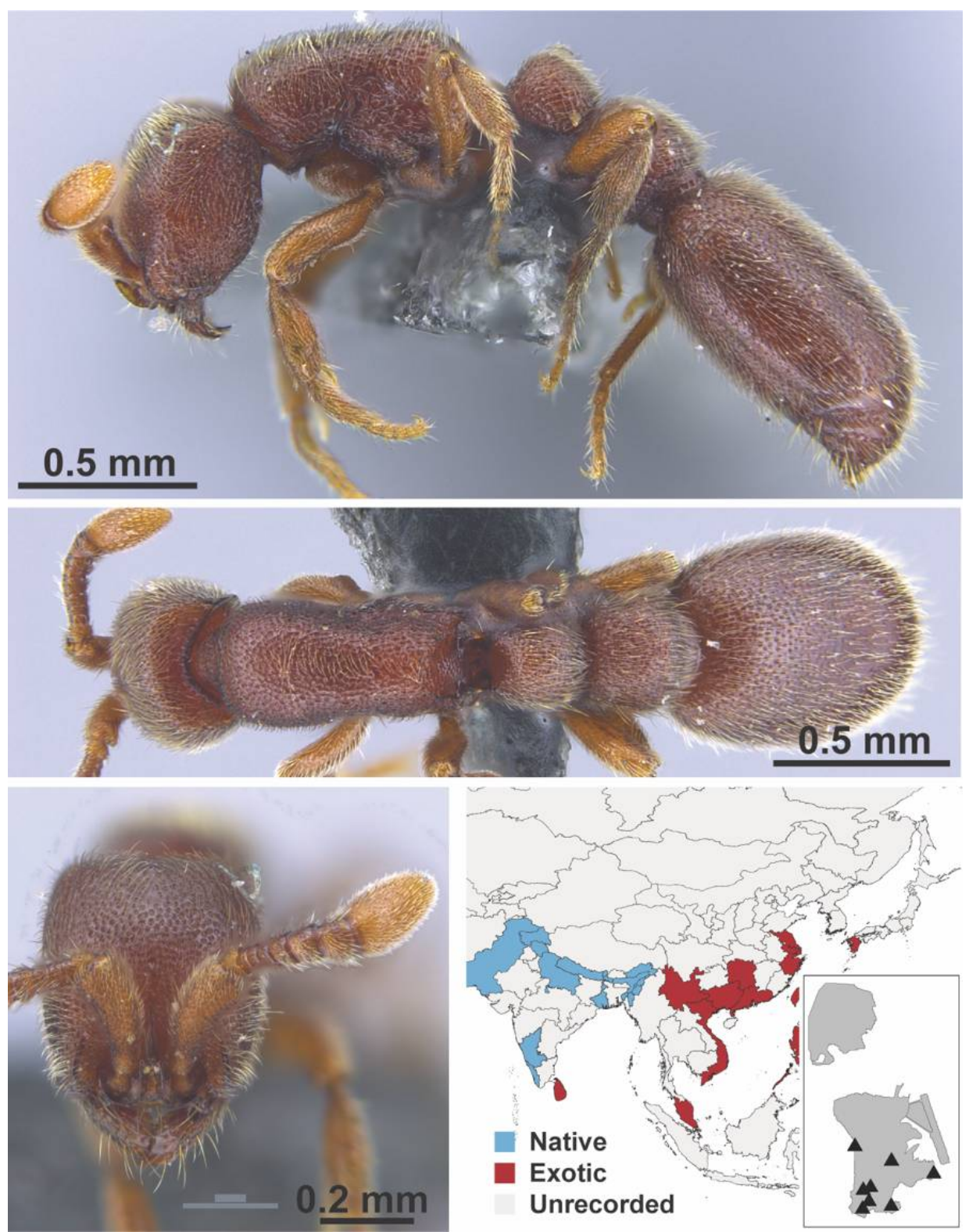

Figure A12. Ooceraea biroi Forel, 1907 worker (MAC_S02_LLSP_Sp.4, IBBL). 
Appendix A.4 FORMICINAE
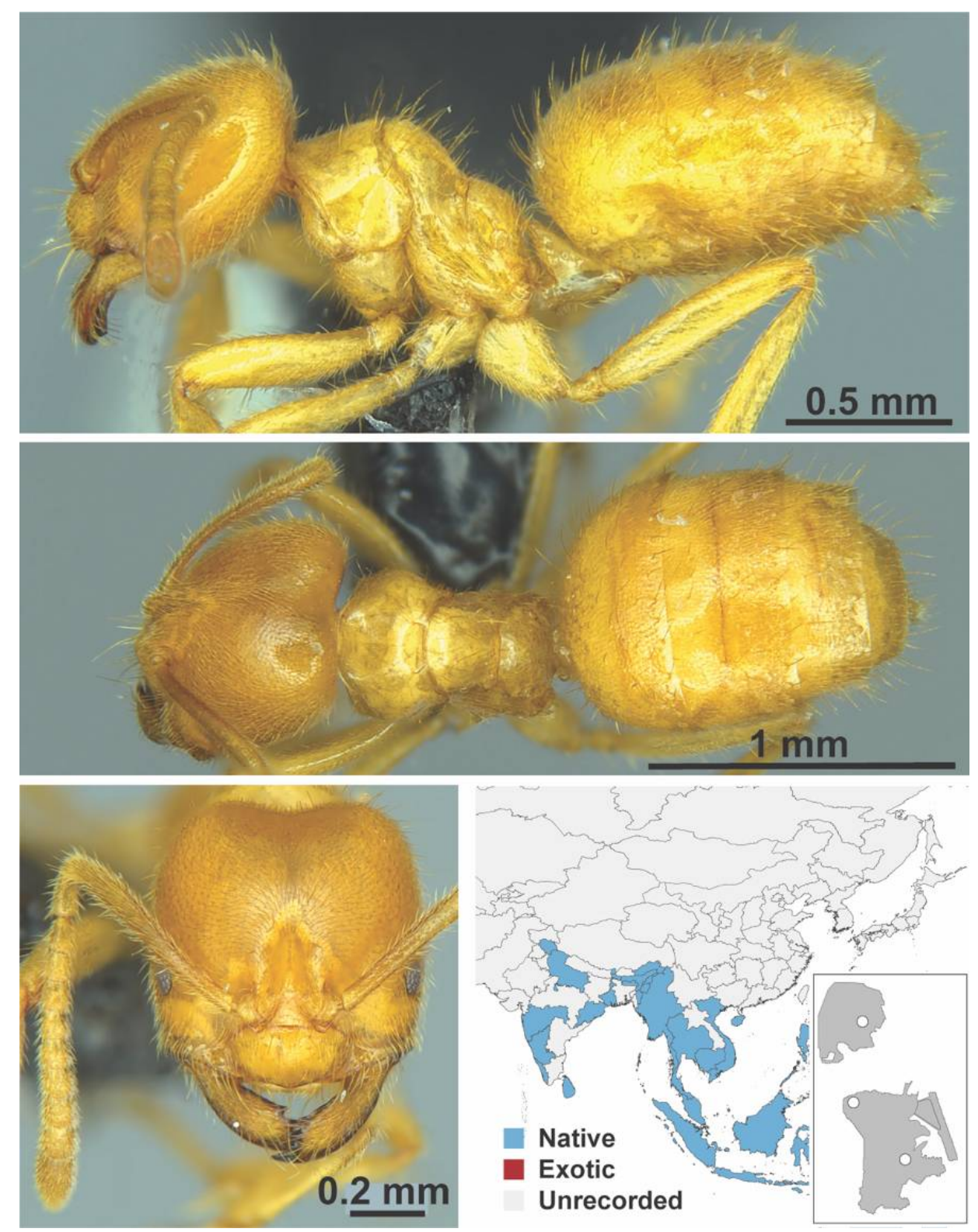

Figure A13. Acropyga acutiventris Roger, 1962 worker (Acropyga acutiventris, CML collection). 

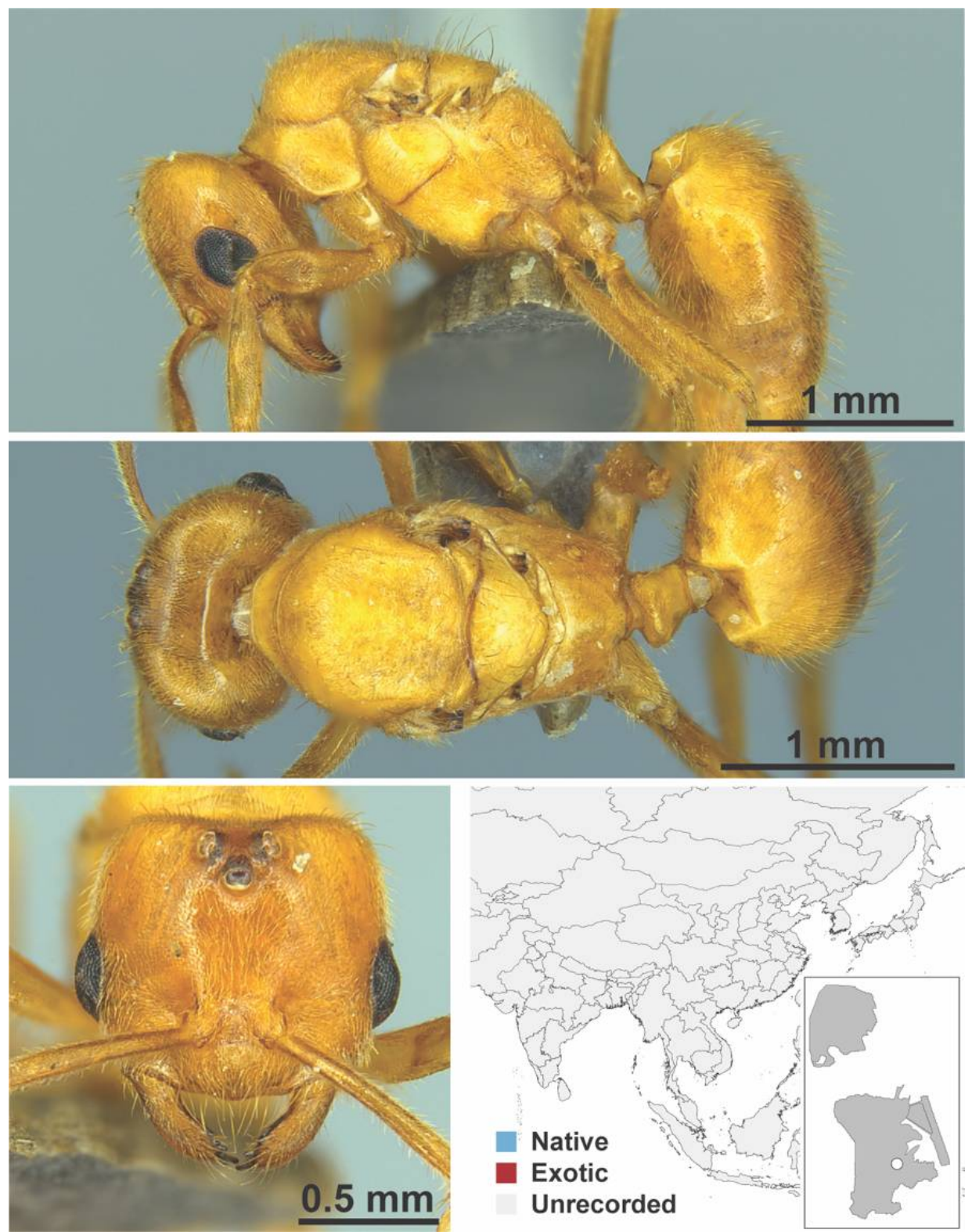

Figure A14. Acropyga sp. mo02 gyne (Acropyga sp. mo02, CML collection). 


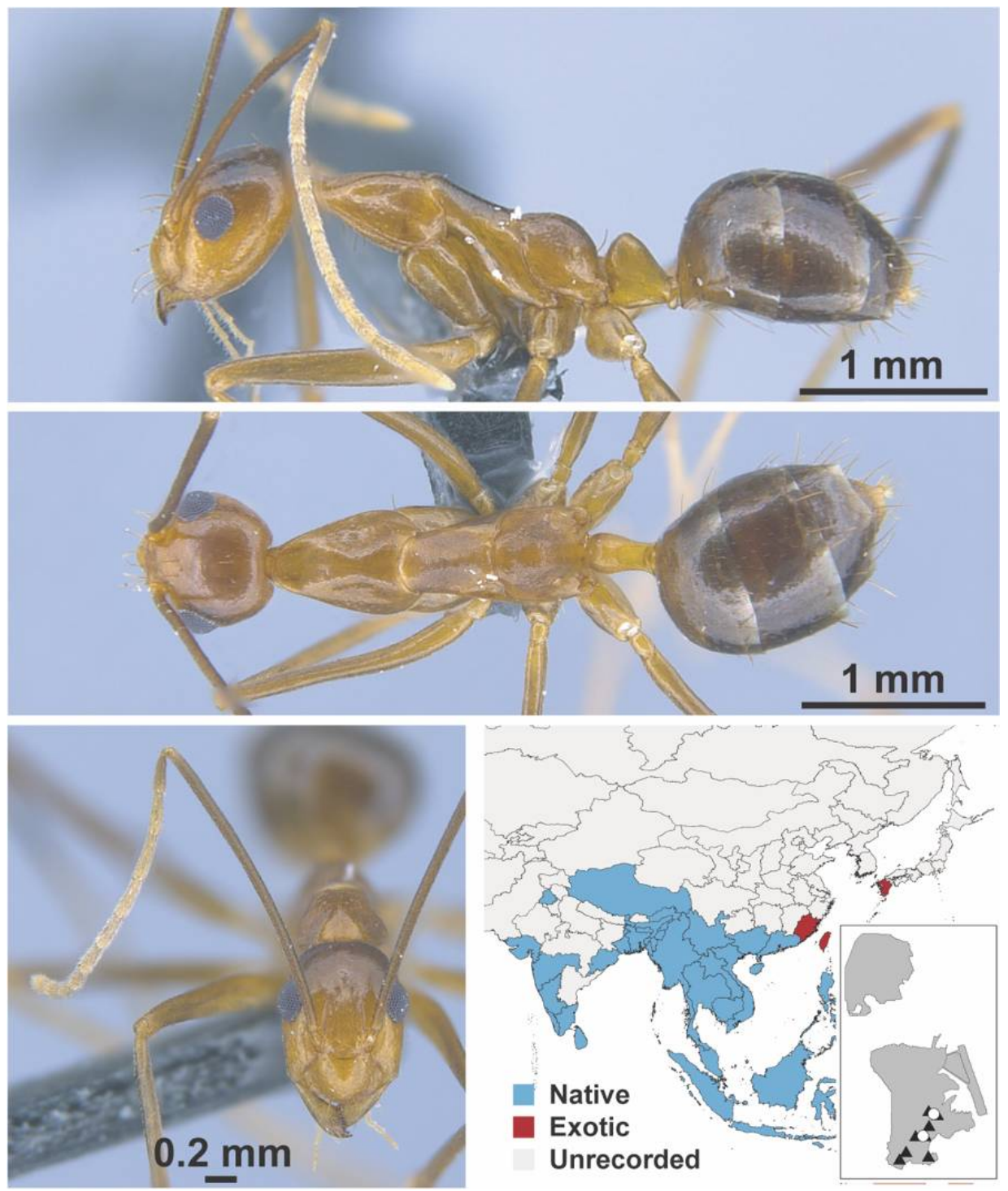

Figure A15. Anoplolepis gracilipes Smith, 1857 worker (MAC_S14_LLSA_Sp.14, IBBL). 

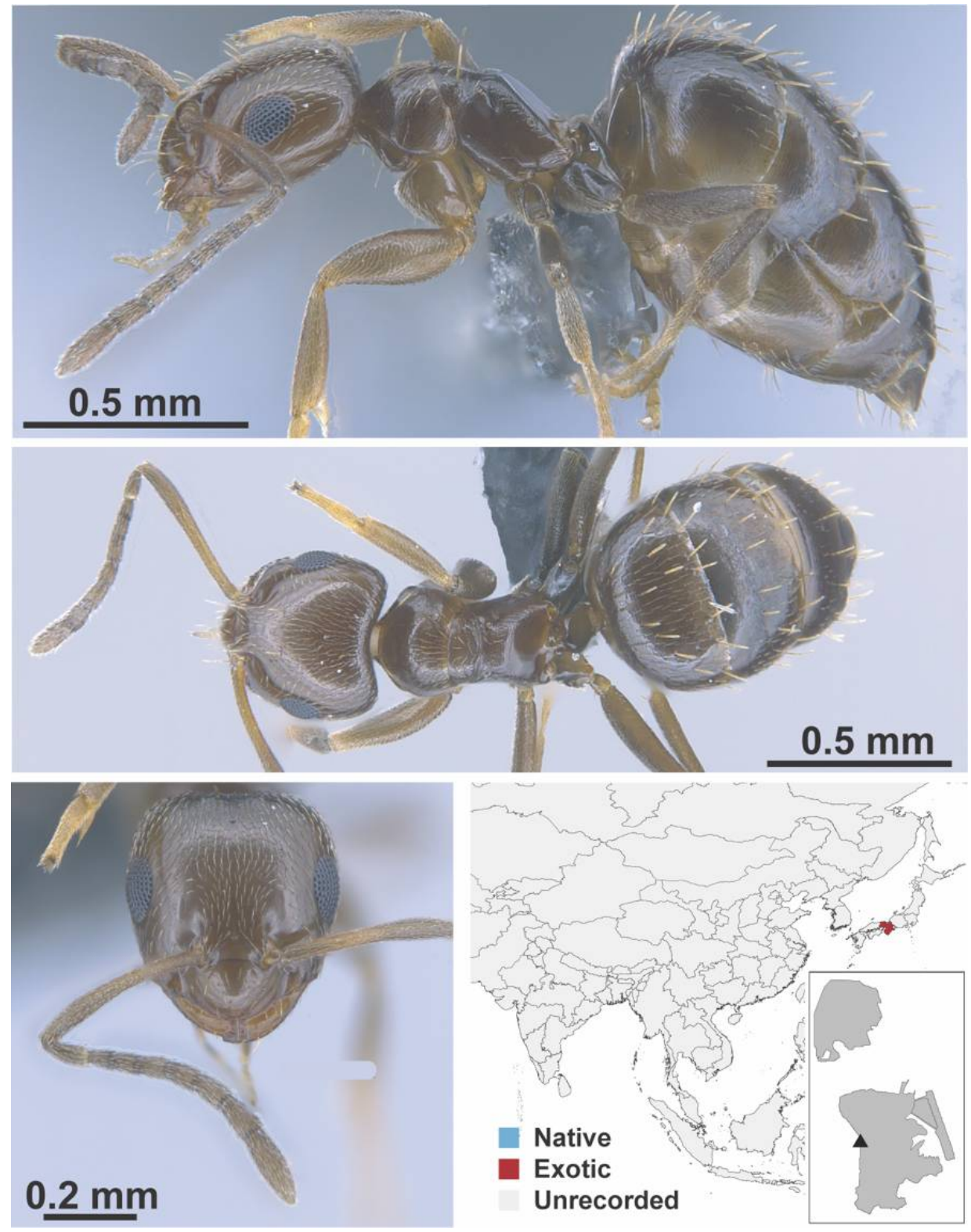

Figure A16. Brachymyrmex patagonicus Mayr, 1868 worker (FB19202, IBBL). 

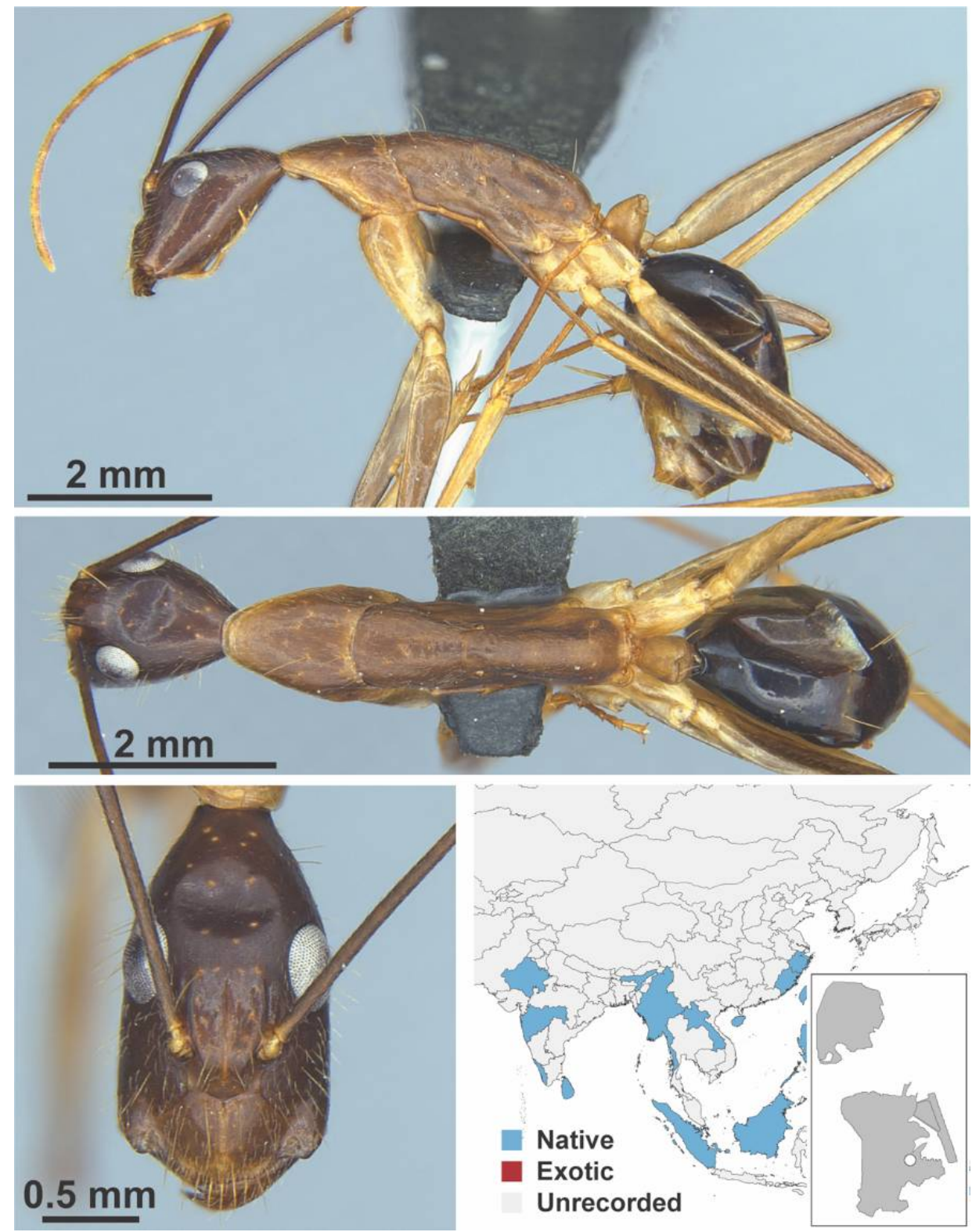

Figure A17. Camponotus carin Emery, 1889 worker (Camponotus carin, CML collection). 

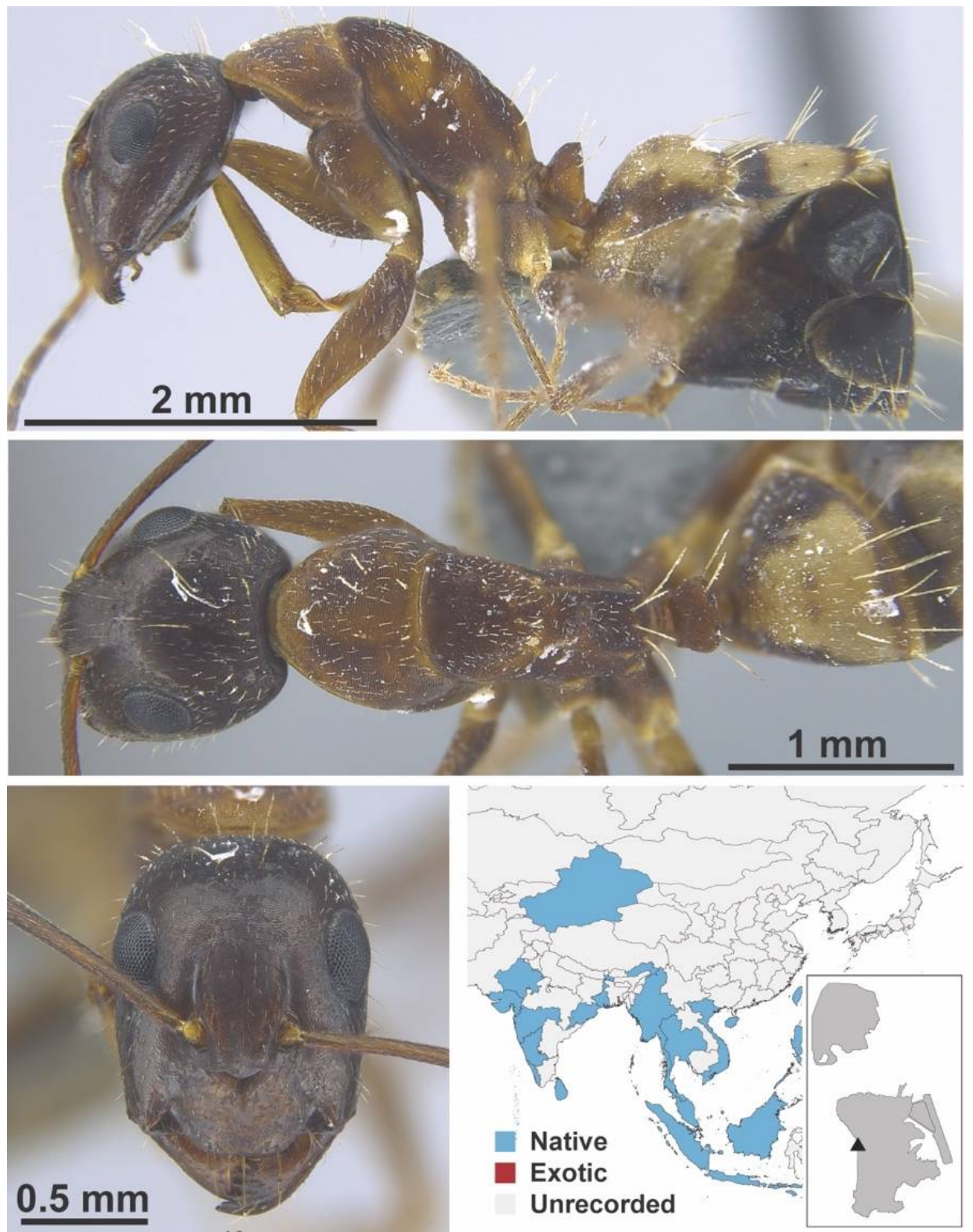

Figure A18. Camponotus nr. irritans Smith, F., 1857 worker (MAC_S20_B08, IBBL). 


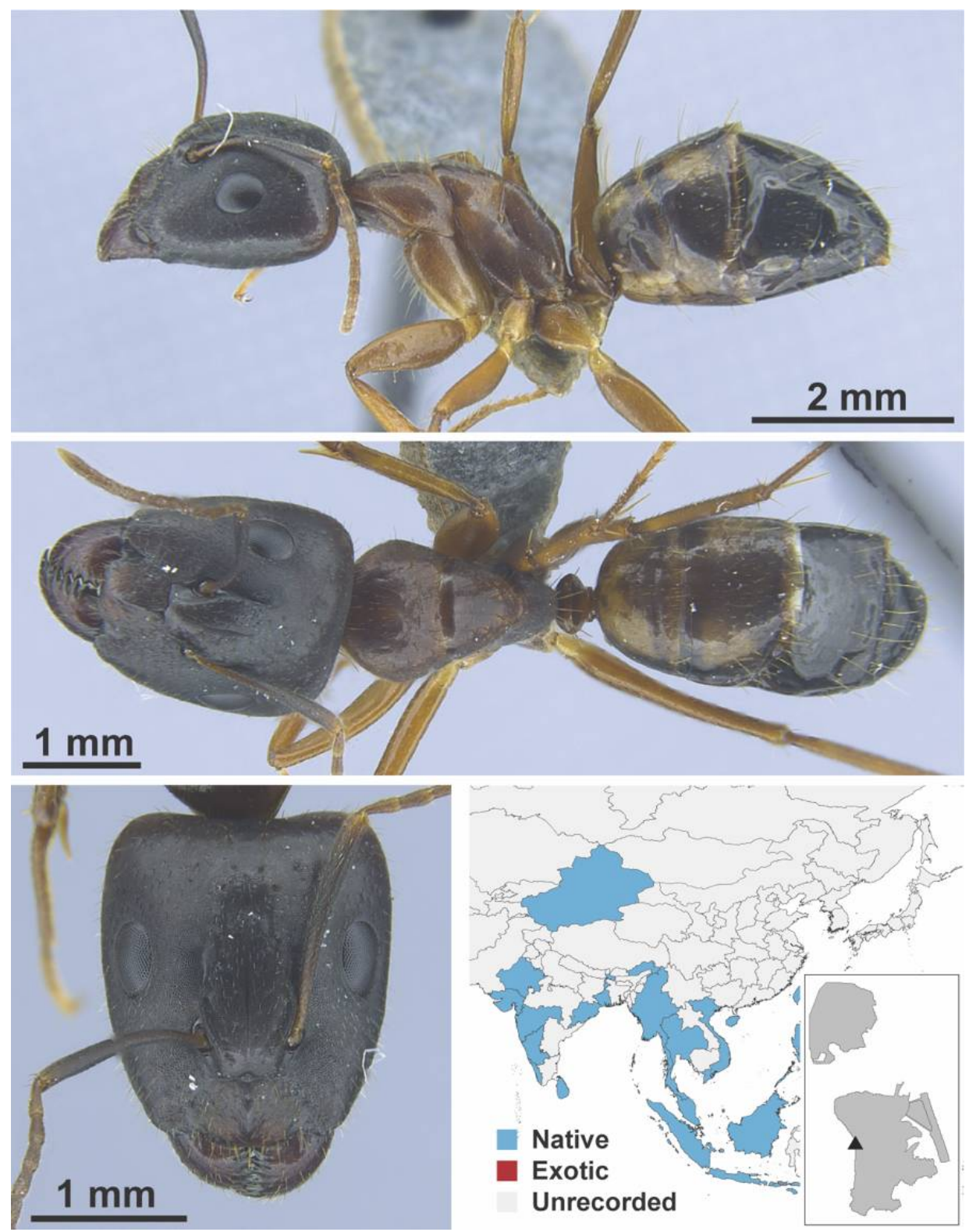

Figure A19. Camponotus nr. irritans Smith, F., 1857 major (MAC_S20_B08, IBBL). 

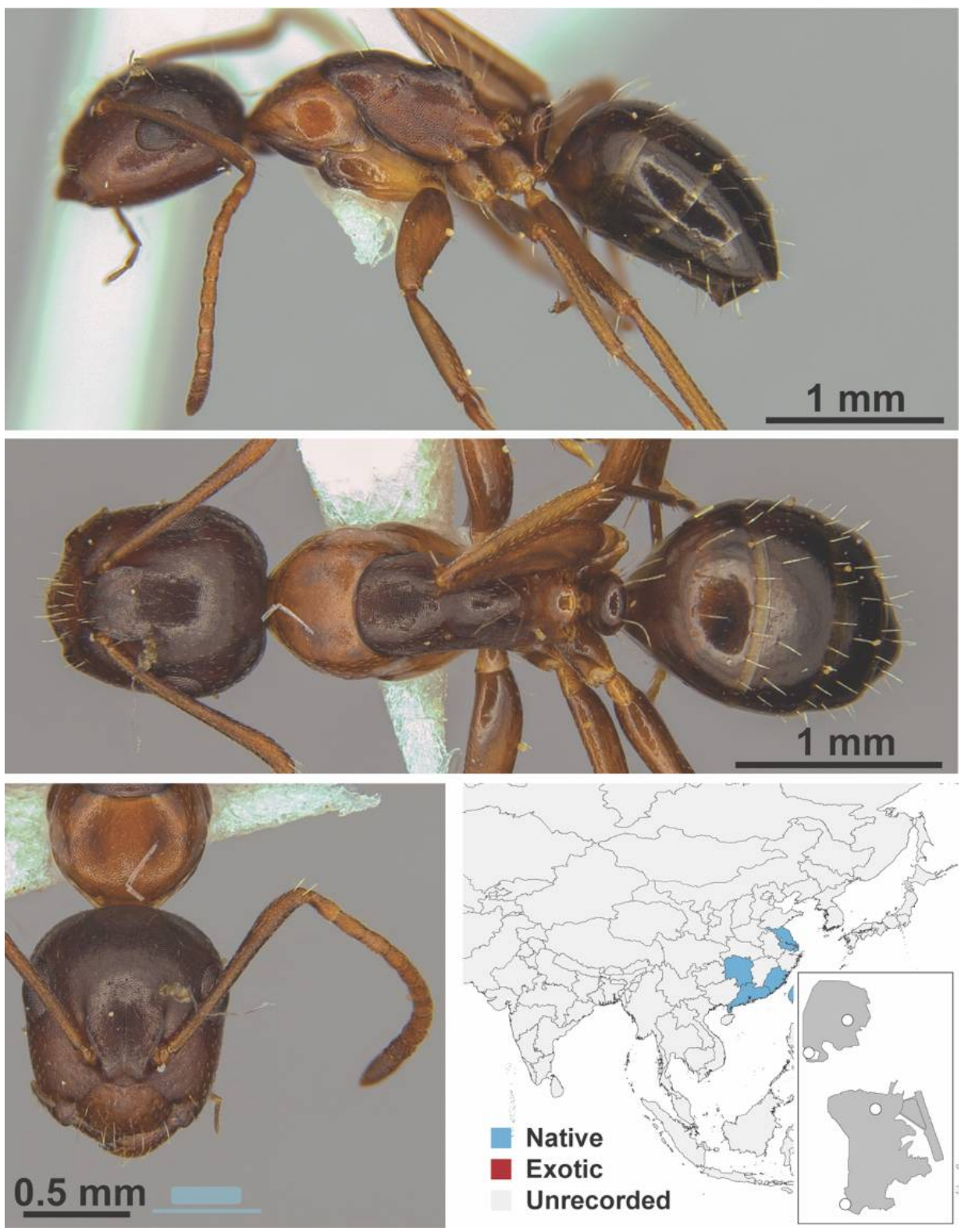

Figure A20. Camponotus lighti Wheeler, 1927 worker (Camponotus lighti, CML collection). 

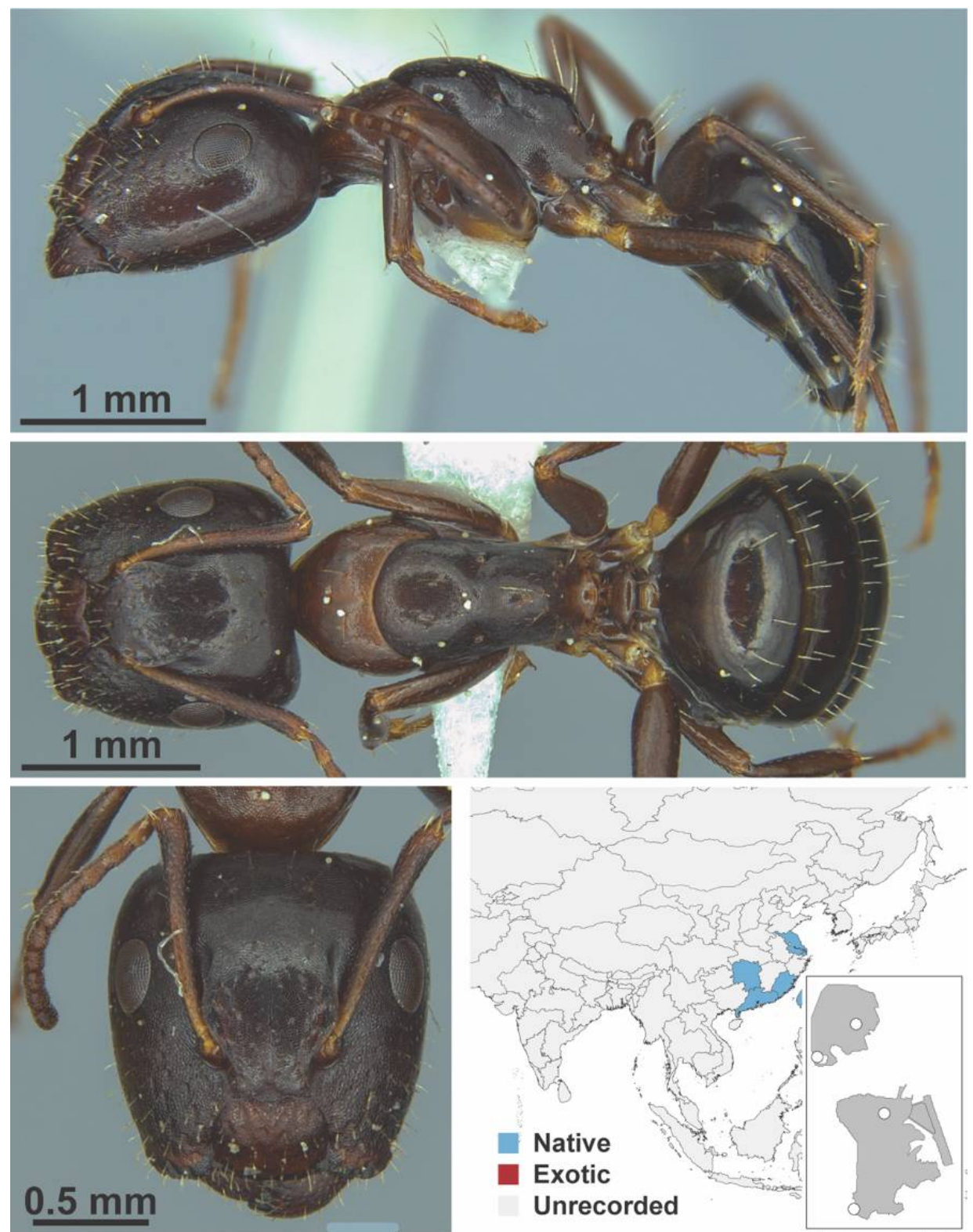

Figure A21. Camponotus lighti Wheeler, 1927 major (Camponotus lighti, CML collection). 

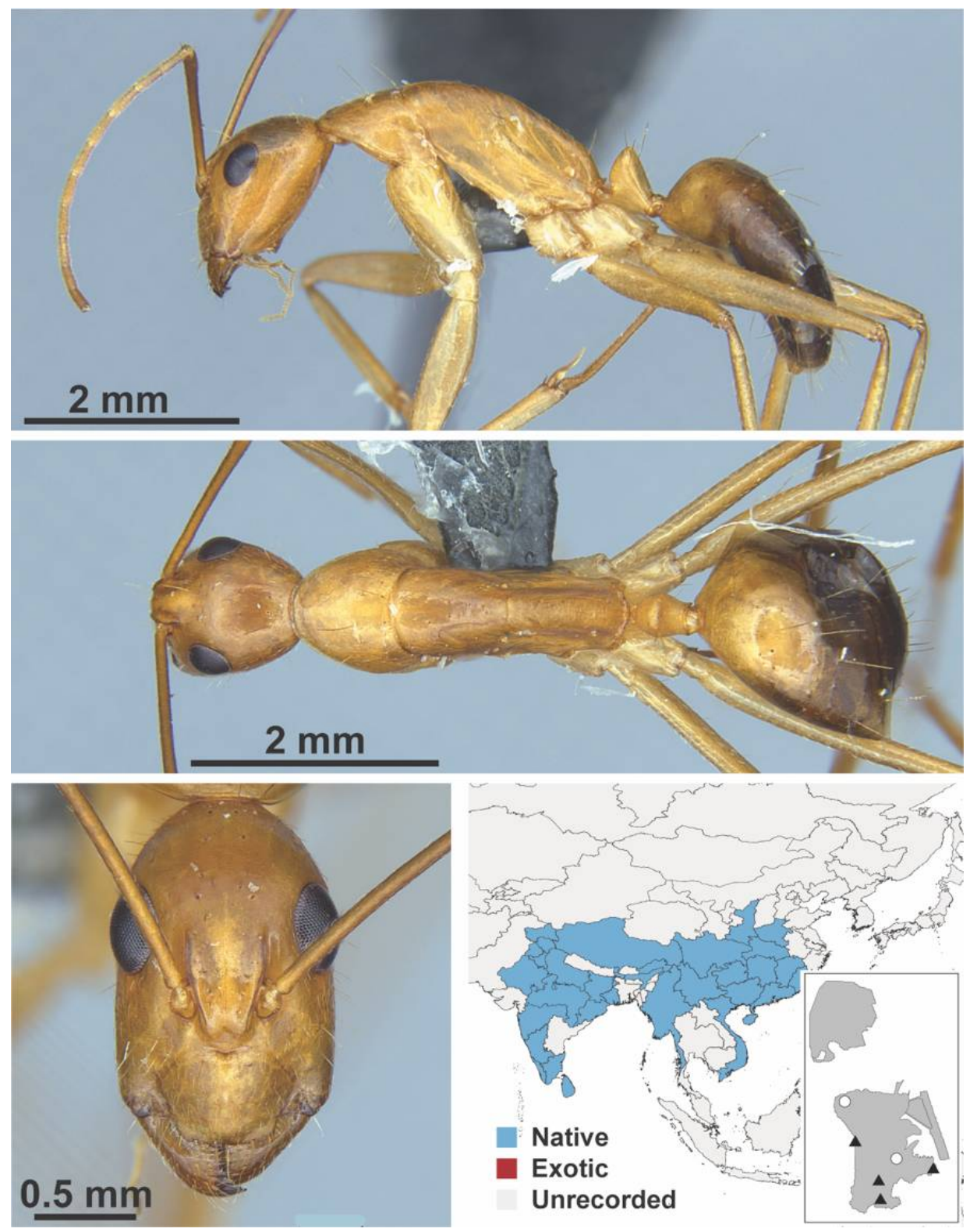

Figure A22. Camponotus mitis Smith, 1858 worker (MAC_S07_LLSA_sp.1, IBBL). 

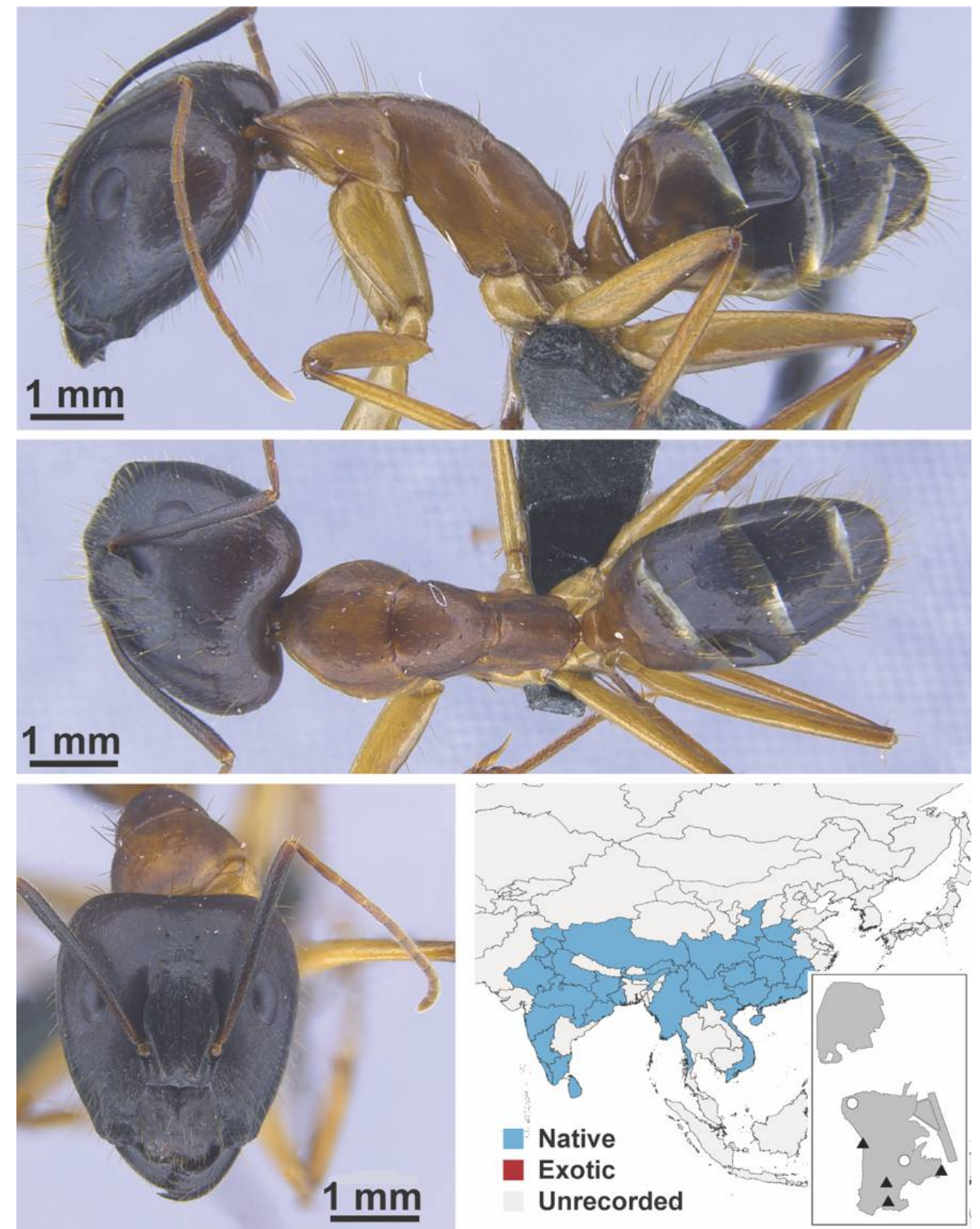

Figure A23. Camponotus mitis Smith, 1858 major (MAC_S11_LLSP_Sp.12, IBBL). 


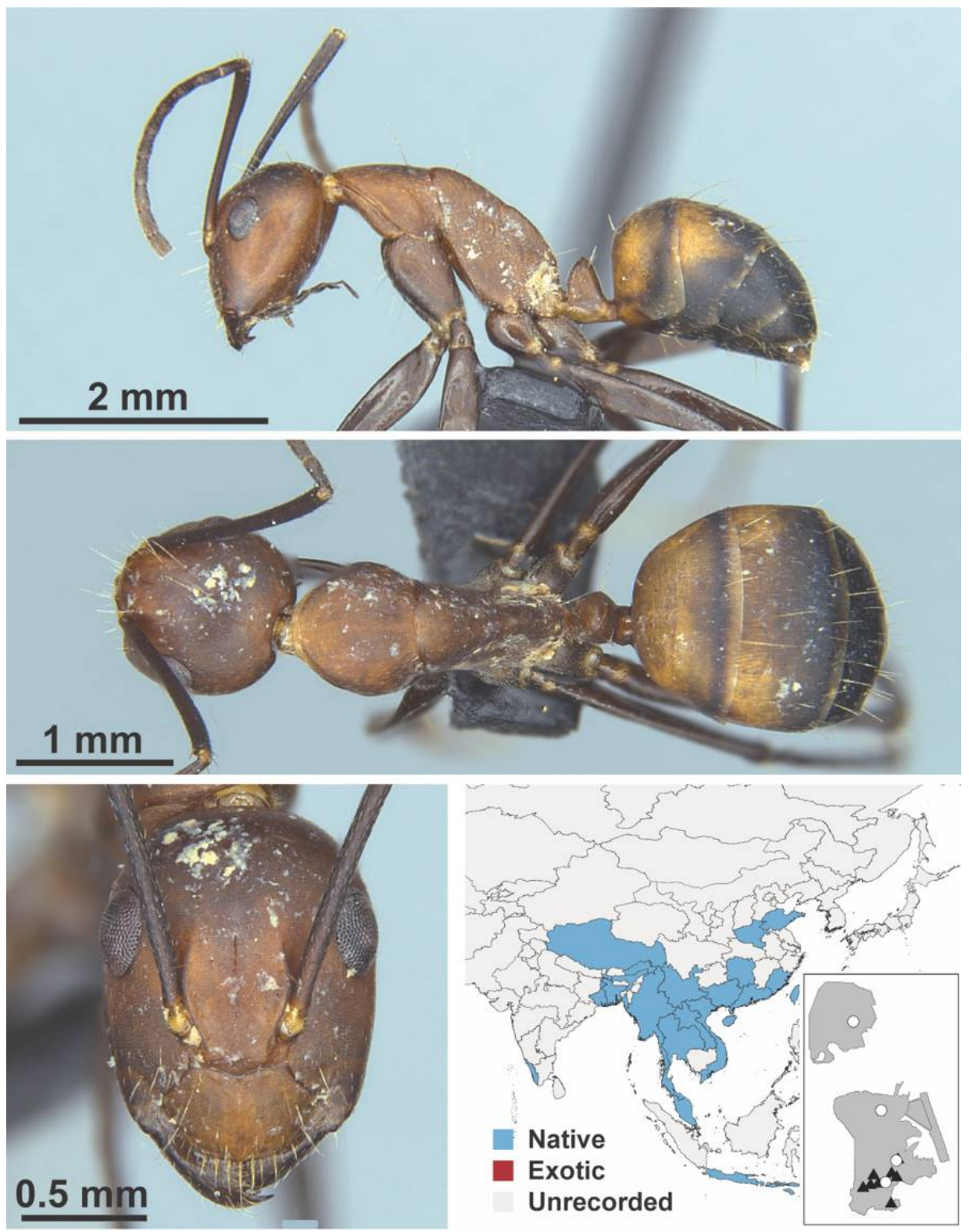

Figure A24. Camponotus nicobarensis Mayr, 1865 worker (MAC_S21_LLSP, IBBL). 


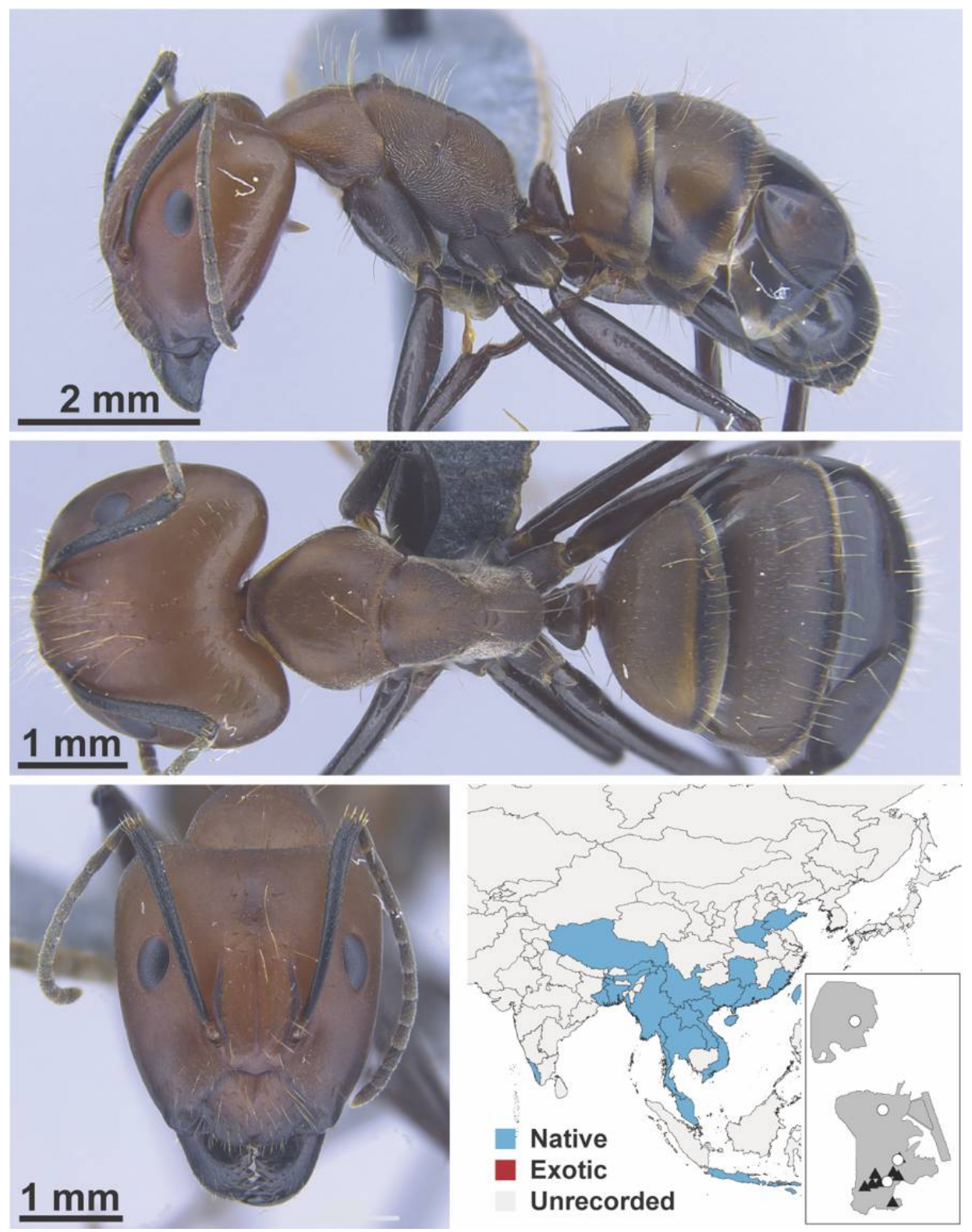

Figure A25. Camponotus nicobarensis Mayr, 1865 major (MAC_S16_T1_5m_sp.3, IBBL). 

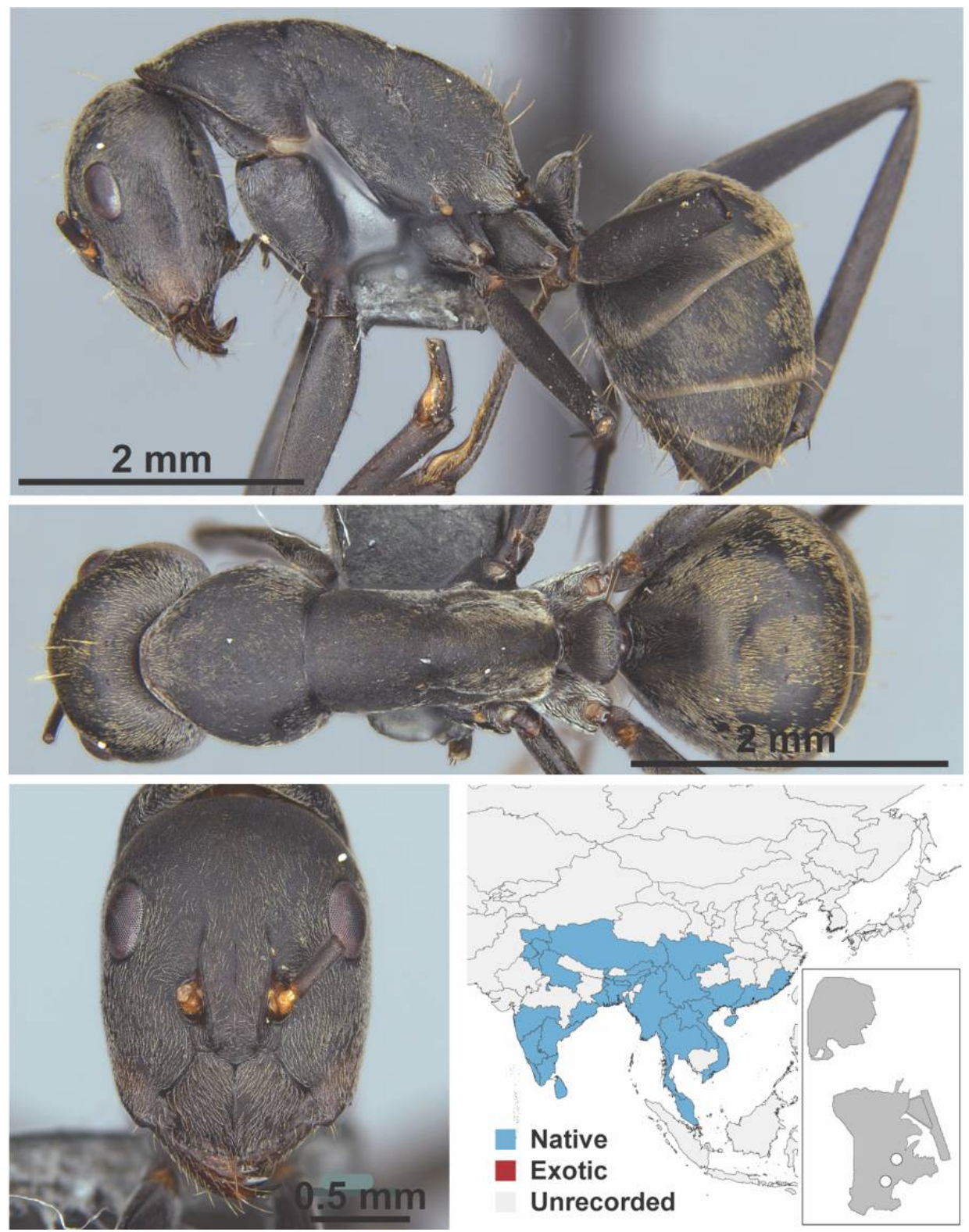

Figure A26. Camponotus parius Emery, 1889 worker (Camponotus parius, CML collection). 

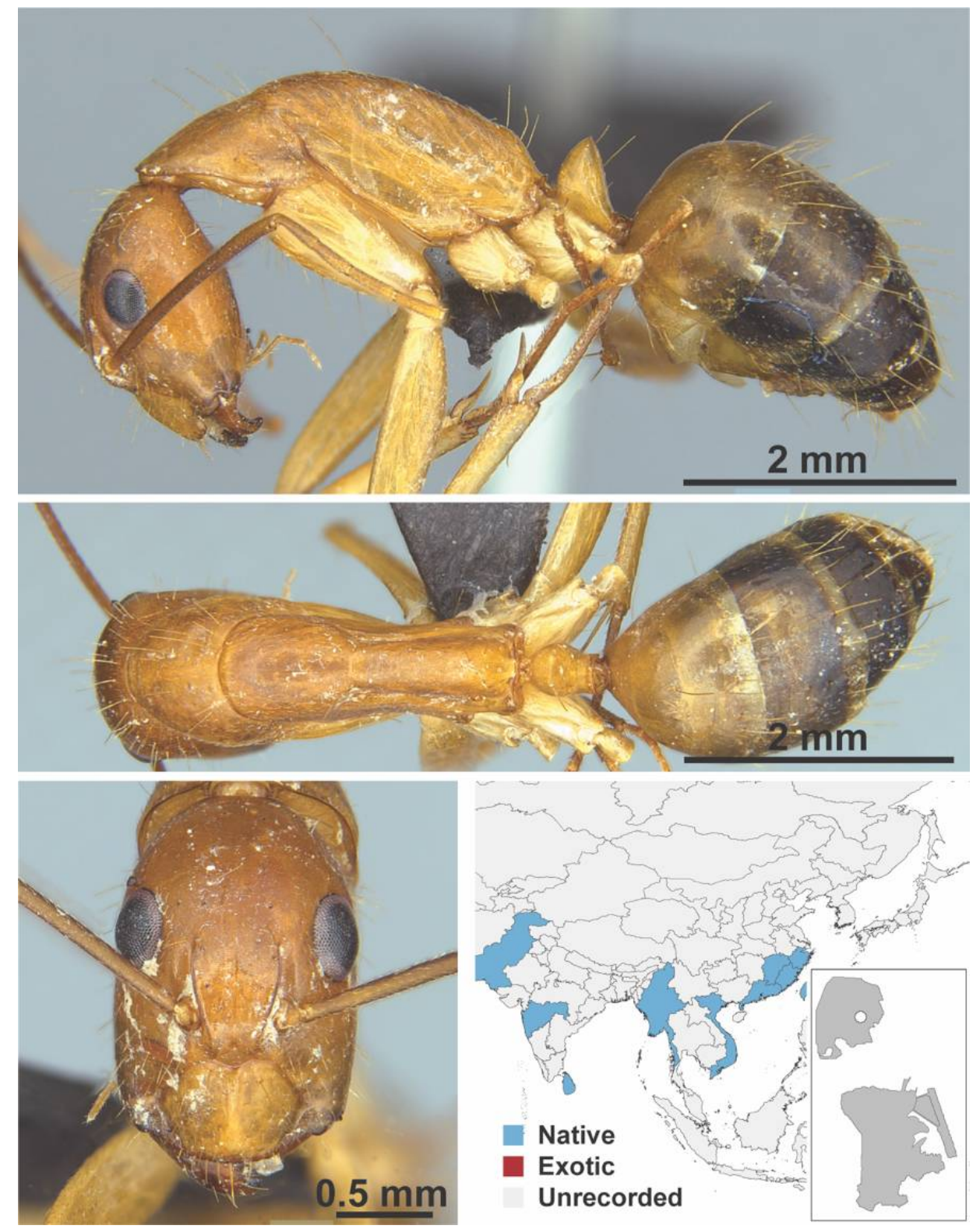

Figure A27. Camponotus variegatus dulcis Dalla Torre, 1893 worker (Camponotus variegatus dulcis, CML collection). 


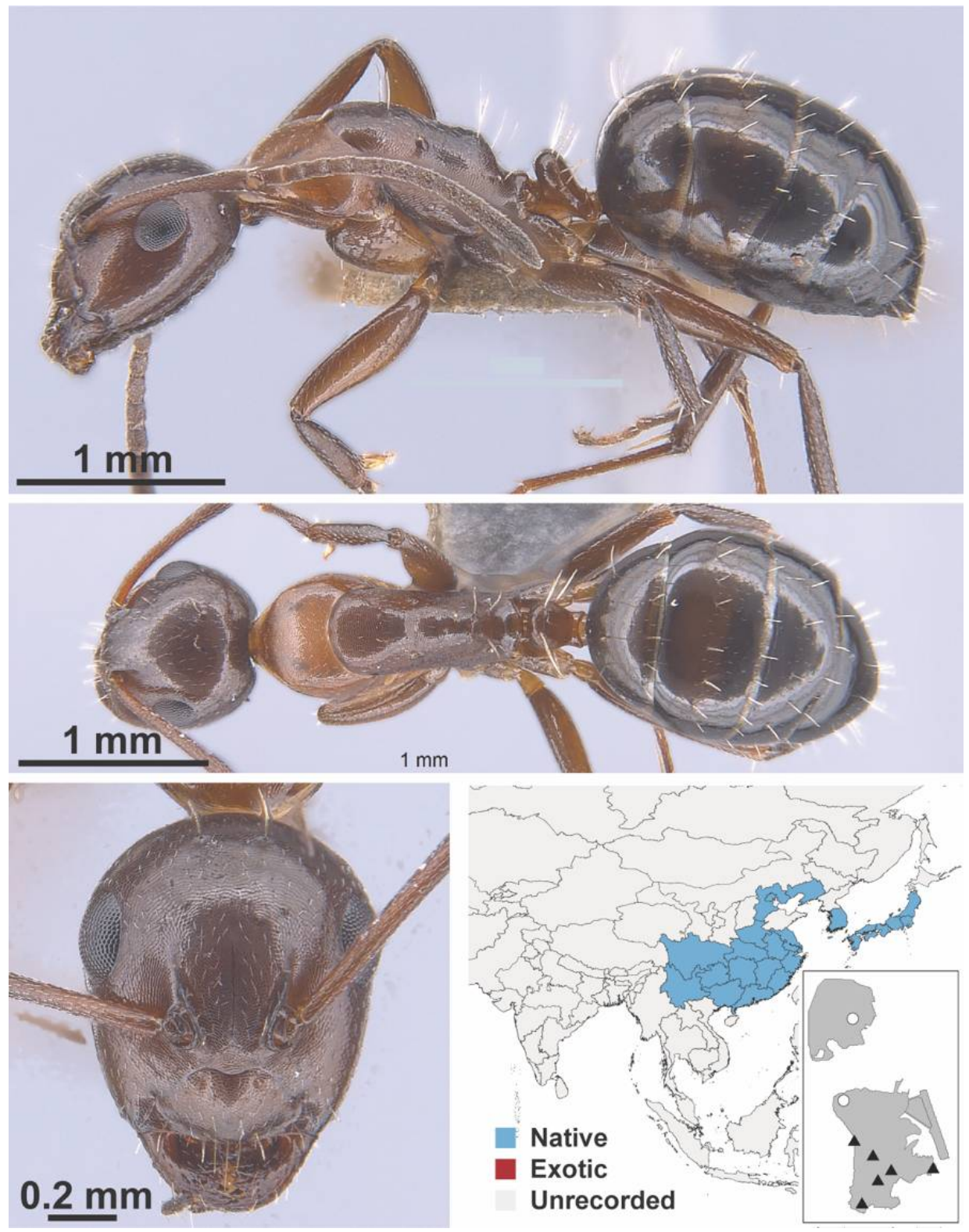

Figure A28. Camponotus vitiosus Smith, 1874 worker (MAC_S20_T4_2m_Sp.1, IBBL). 

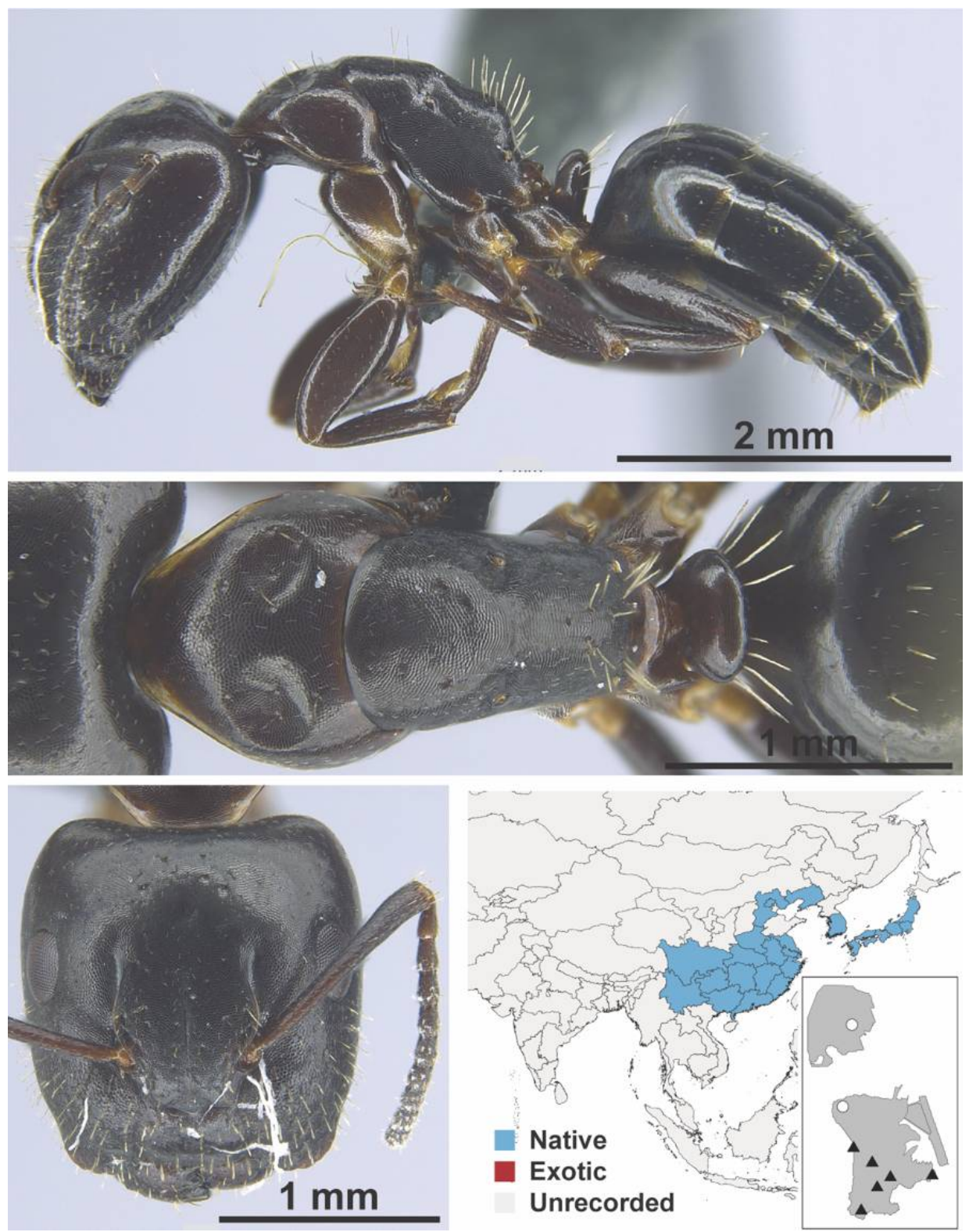

Figure A29. Camponotus vitiosus Smith, 1874 major (MAC_S14_T1_3m_Sp.1, IBBL). 


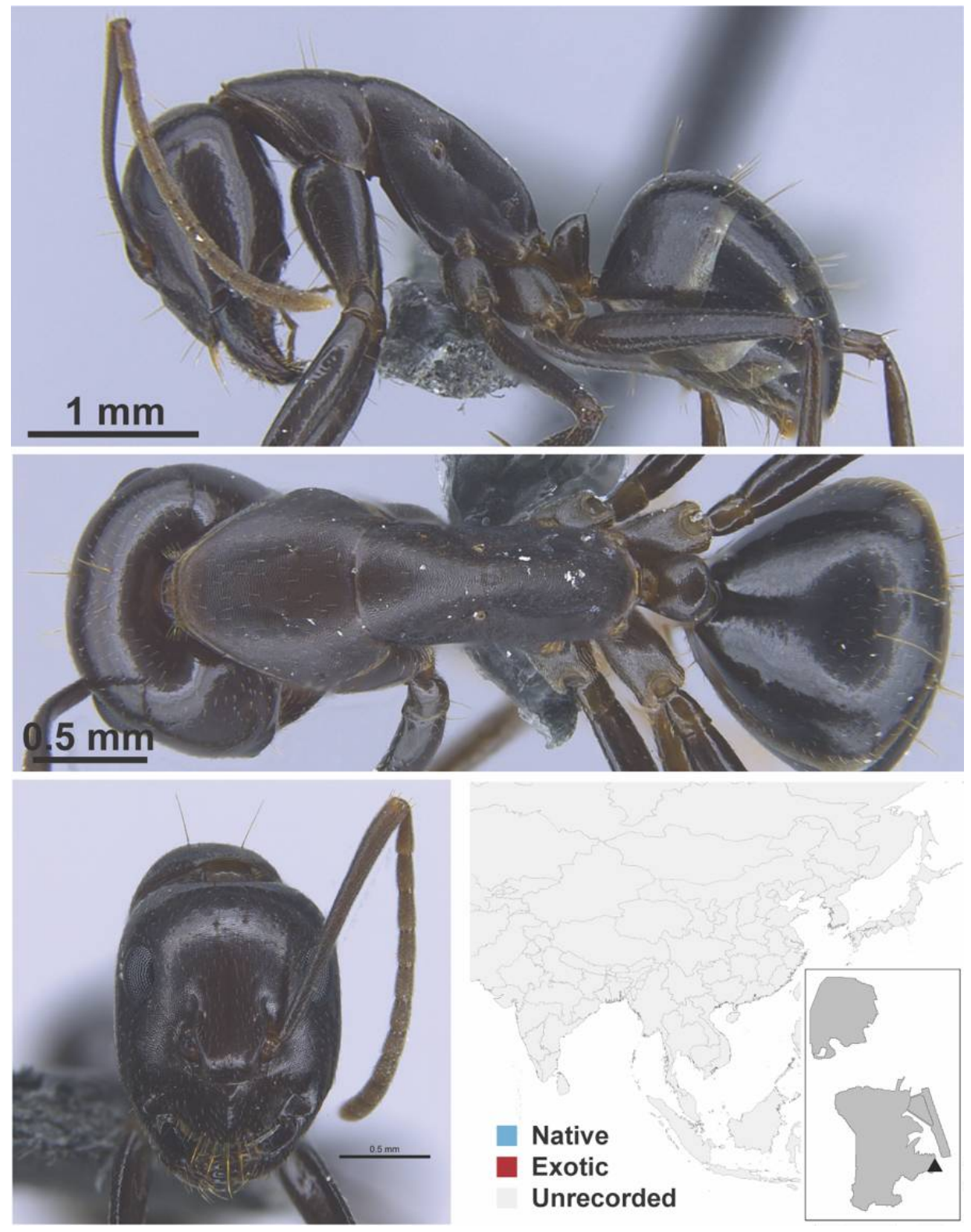

Figure A30. Camponotus sp.1 FB worker (MAC_FB19182, IBBL). 

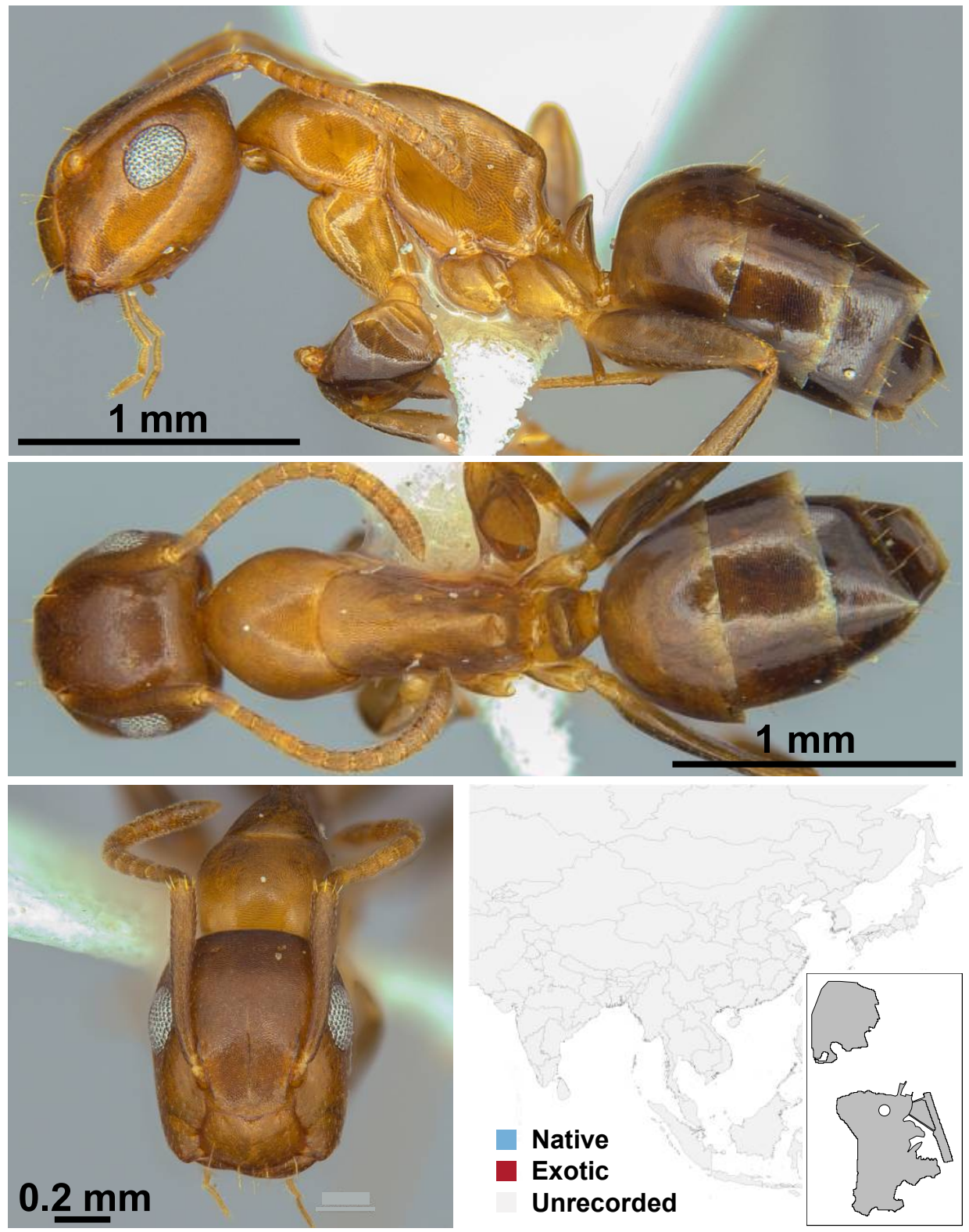

Figure A31. Colobopsis nr. nipponica Wheeler, 1928 worker (Colobopsis nr. nipponica, CML collection). 

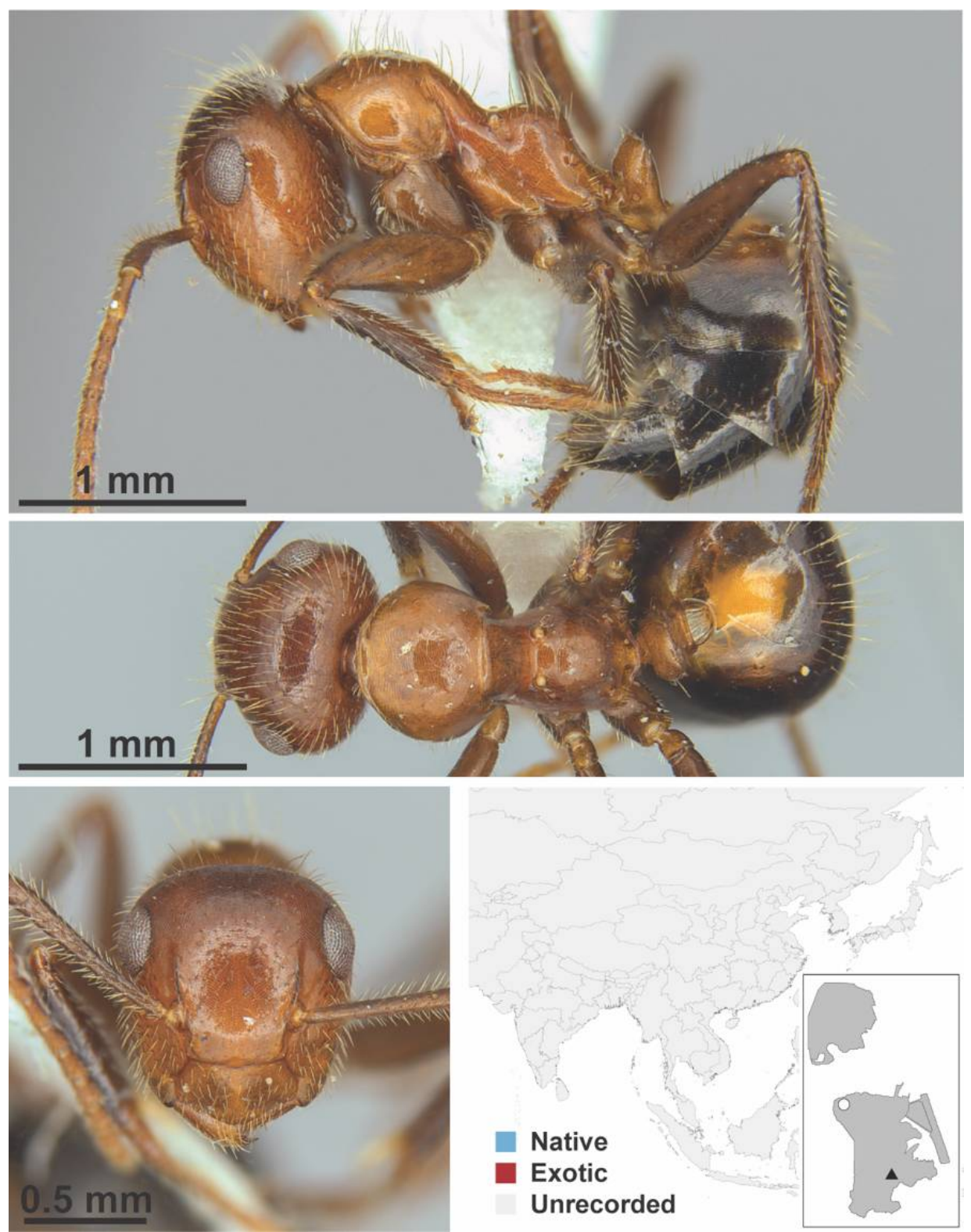

Figure A32. Colobopsis nr. vitrea Smith, 1860 worker (Colobopsis nr. vitrea, CML collection). 

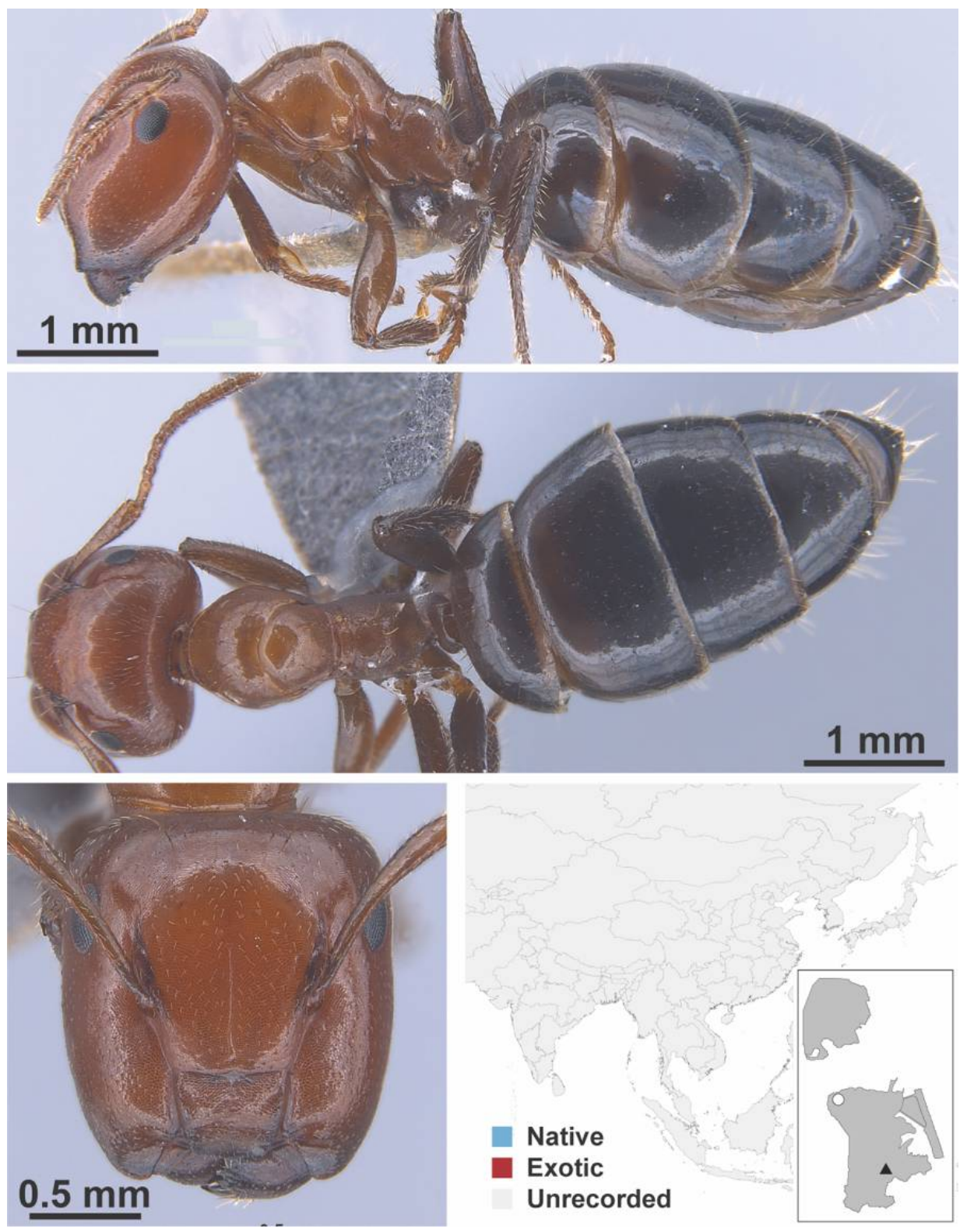

Figure A33. Colobopsis nr. vitrea Smith, 1860 major (FB19268, IBBL). 

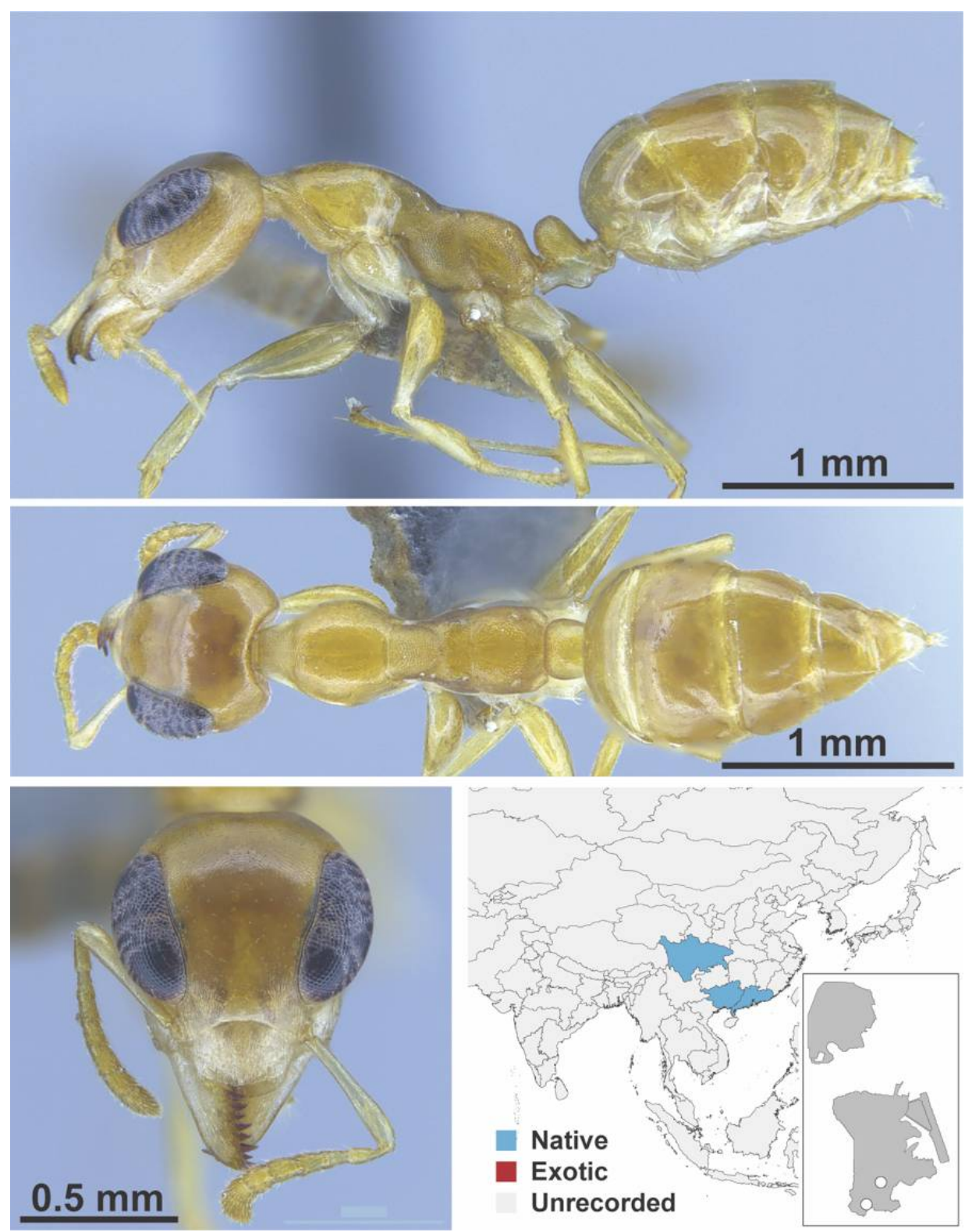

Figure A34. Gesomyrmex howardi Wheeler, W. M., 1921 worker (MWong_MaiPo_7viii2018, IBBL). 


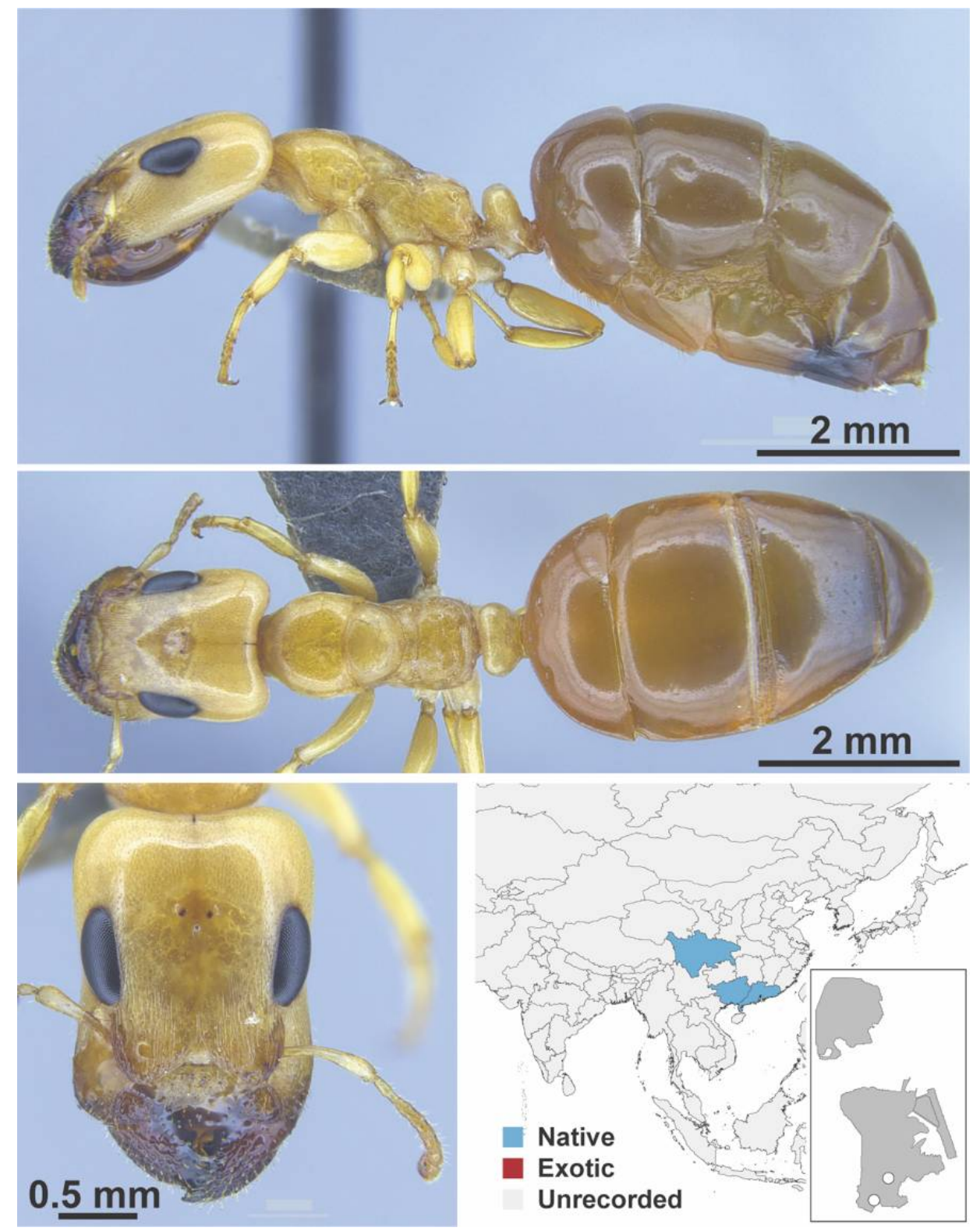

Figure A35. Gesomyrmex howardi Wheeler, W. M., 1921 supermajor (MWong_MaiPo_7viii2018_ Colony4_6_2.6x12.5, IBBL). 

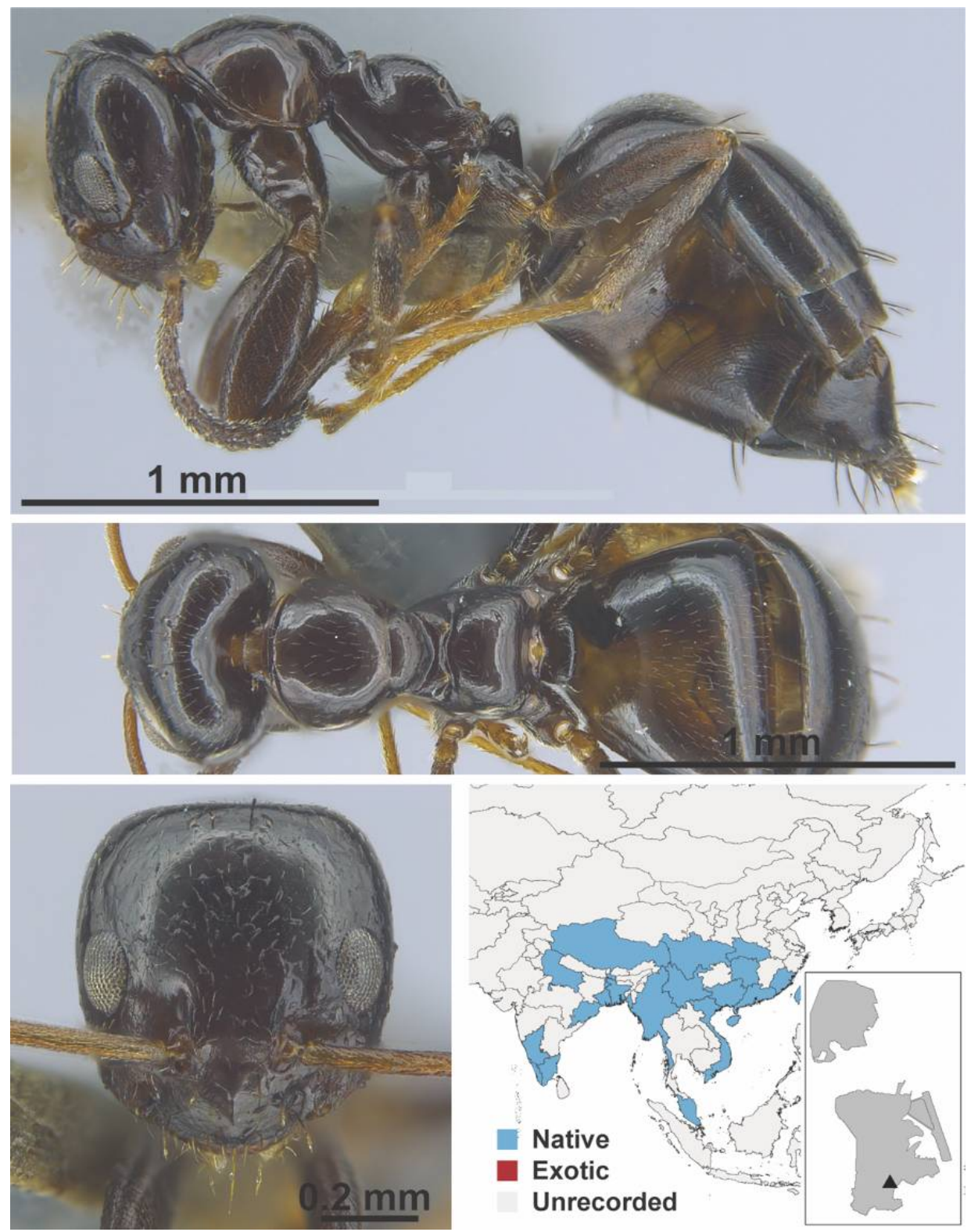

Figure A36. Lepisiota rothneyi Forel, 1894 worker (MAC_S06_B08_Sp.1_top, IBBL). 


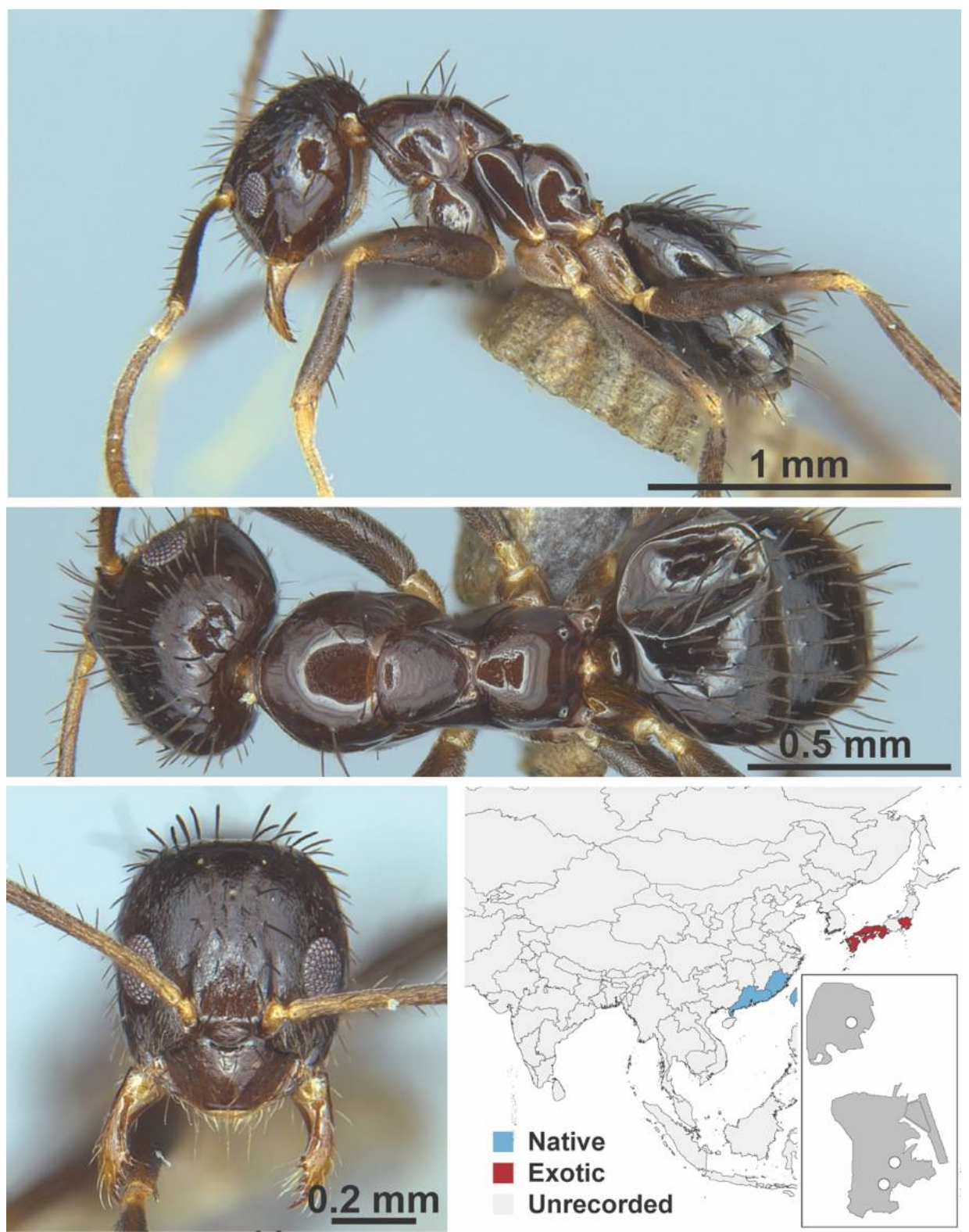

Figure A37. Nylanderia amia Forel, 1913 worker (ANTWEB1016677, IBBL). 

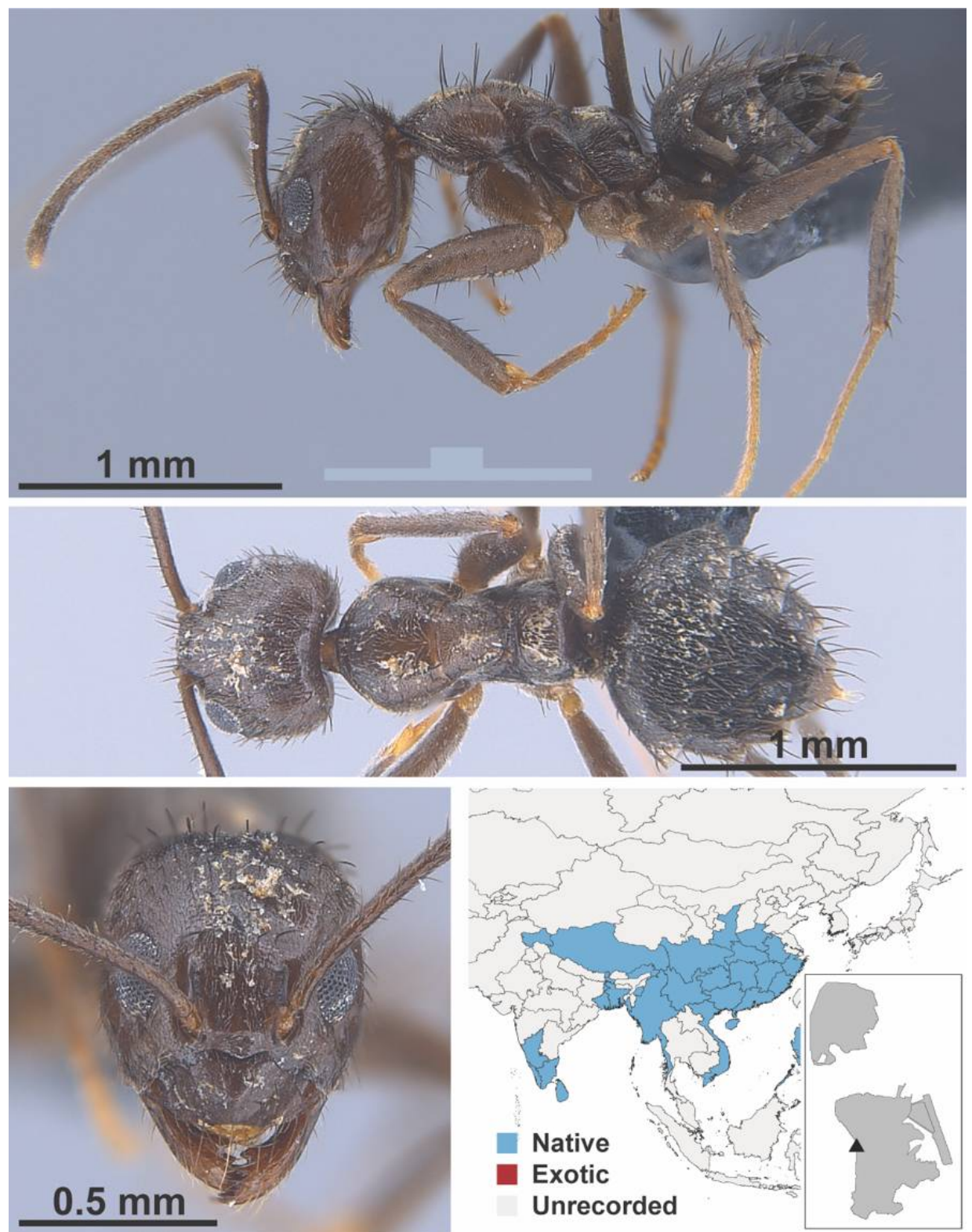

Figure A38. Nylanderia bourbonica Forel, 1886 worker (MAC_S20_LLSP_Sp.4, IBBL). 


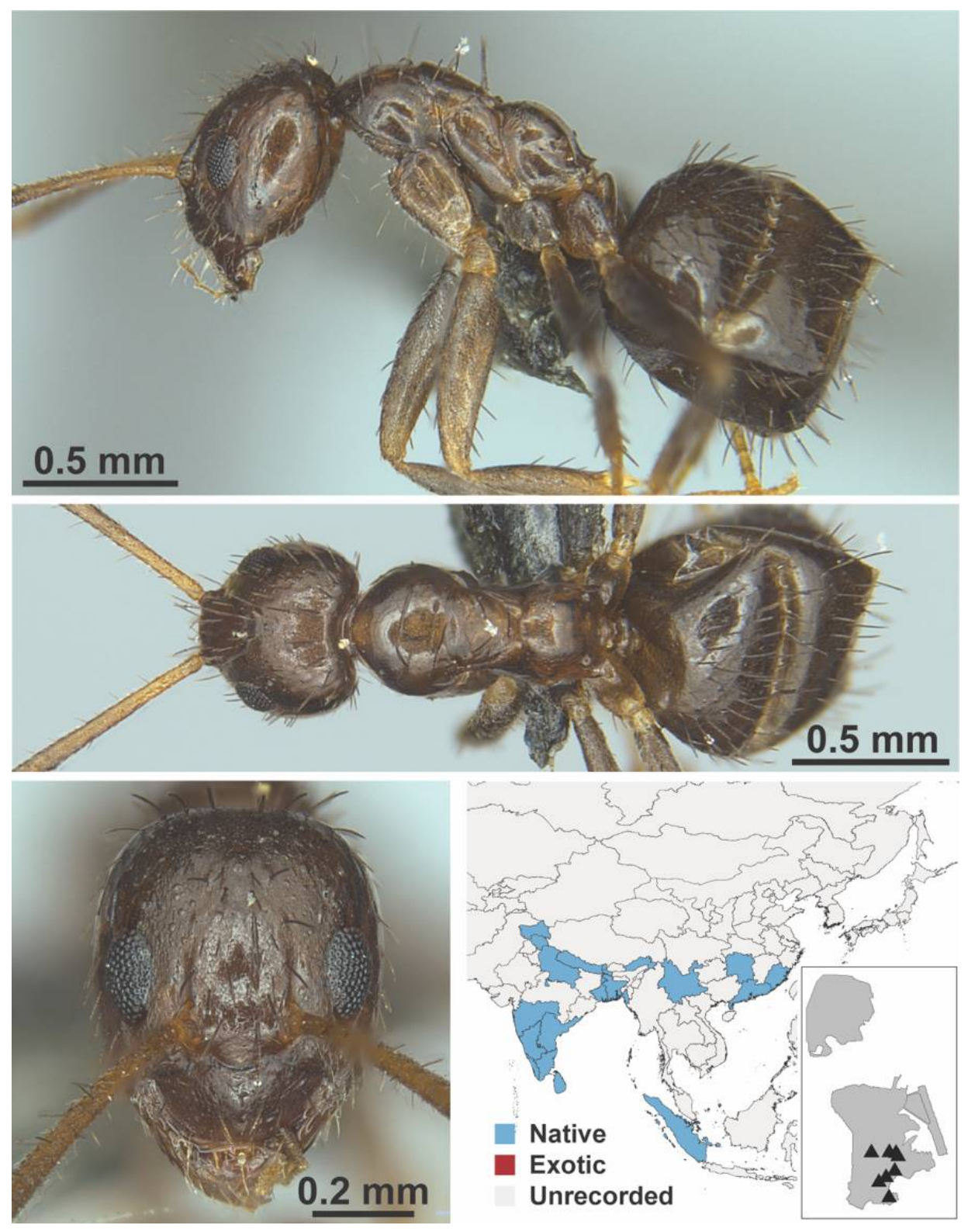

Figure A39. Nylanderia indica Forel, 1894 worker (MAC_S12_LLSP_sp.4, IBBL). 

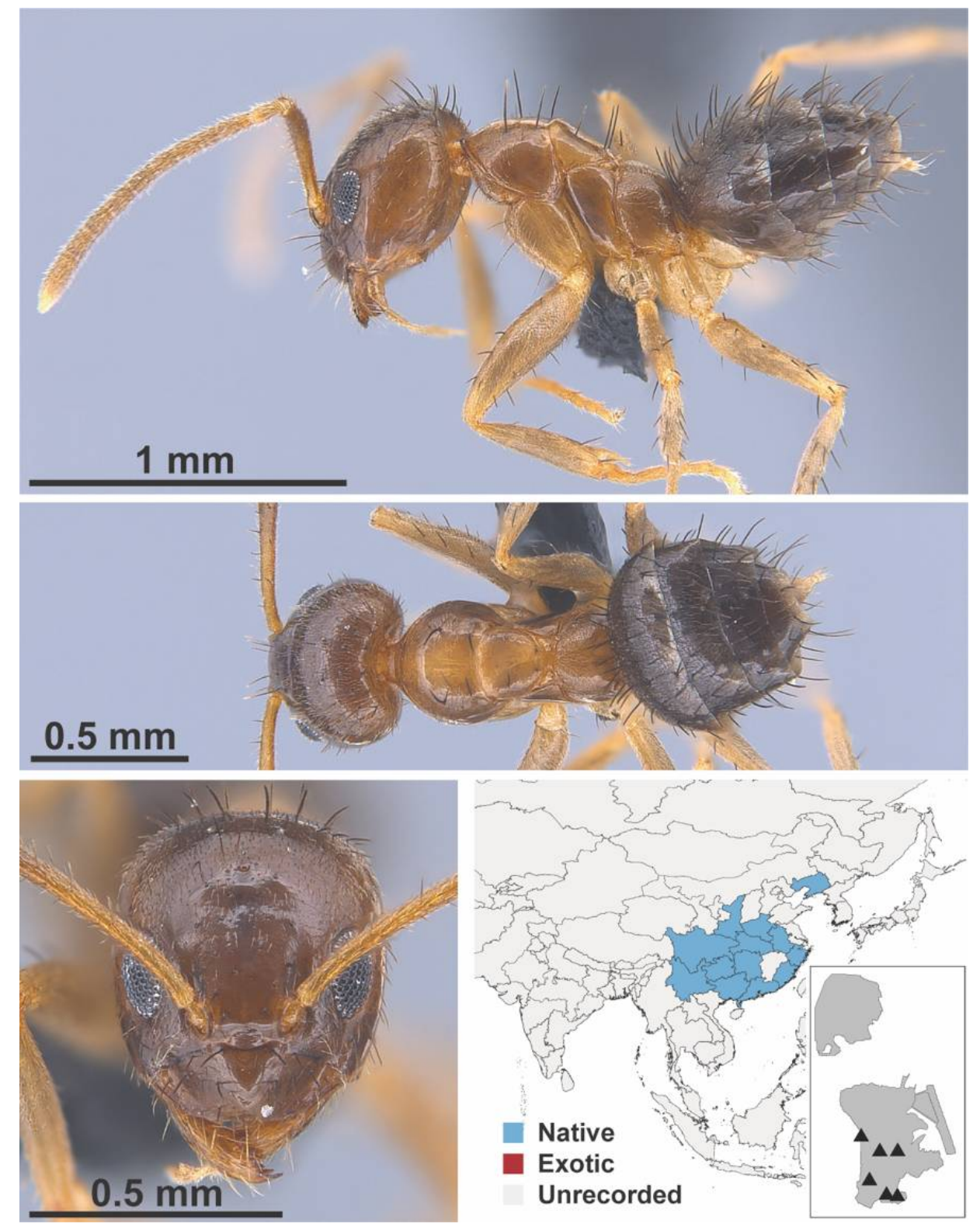

Figure A40. Nylanderia sharpii Forel, 1899 worker (MAC_S19_LLSA_Sp.5, IBBL). 

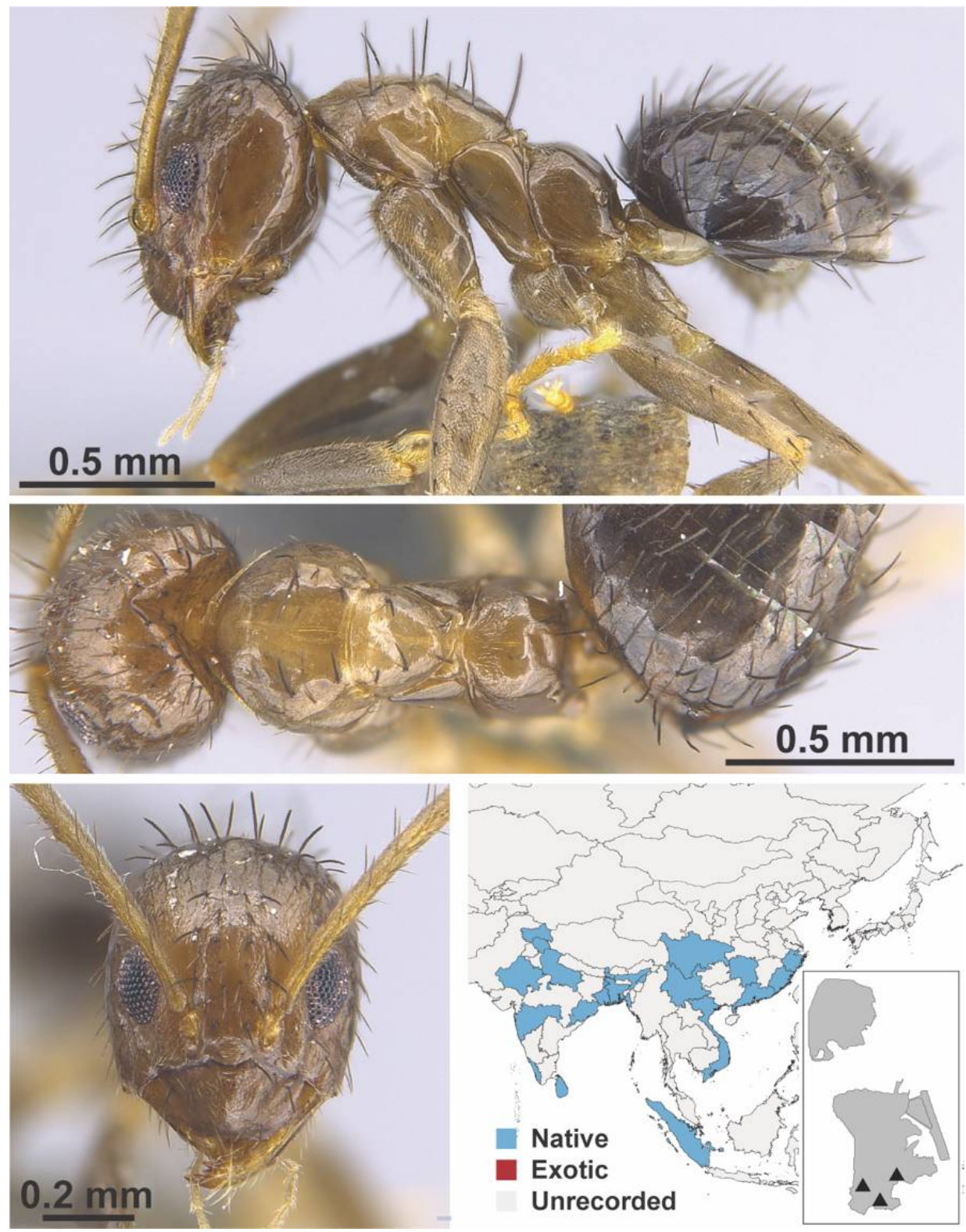

Figure A41. Nylanderia taylori Forel, 1894 worker (MAC_S21_GN1_H4_n1_bottom, IBBL). 

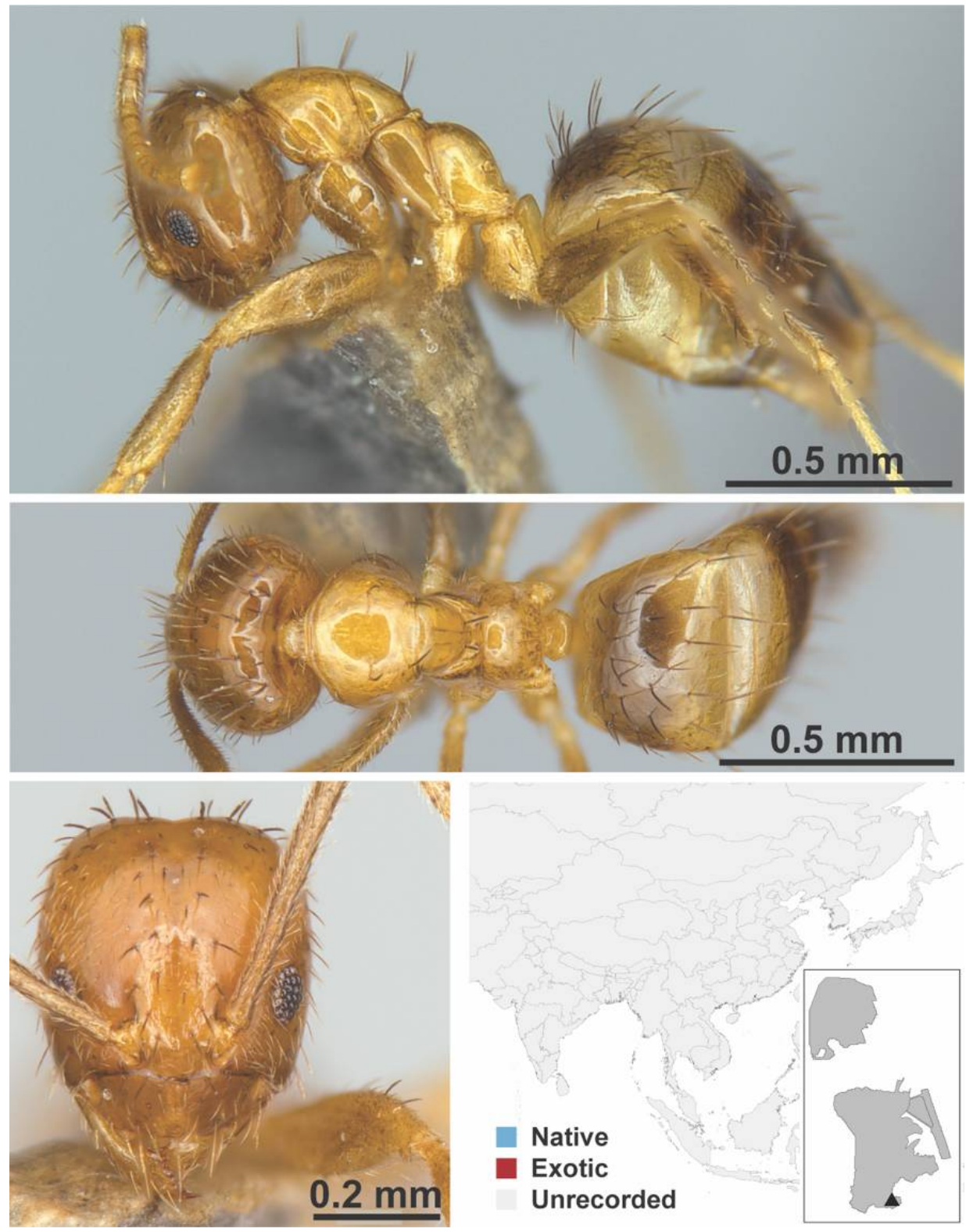

Figure A42. Nylanderia sp. 3 BG worker (MAC_S15_B03_sp.3, IBBL). 

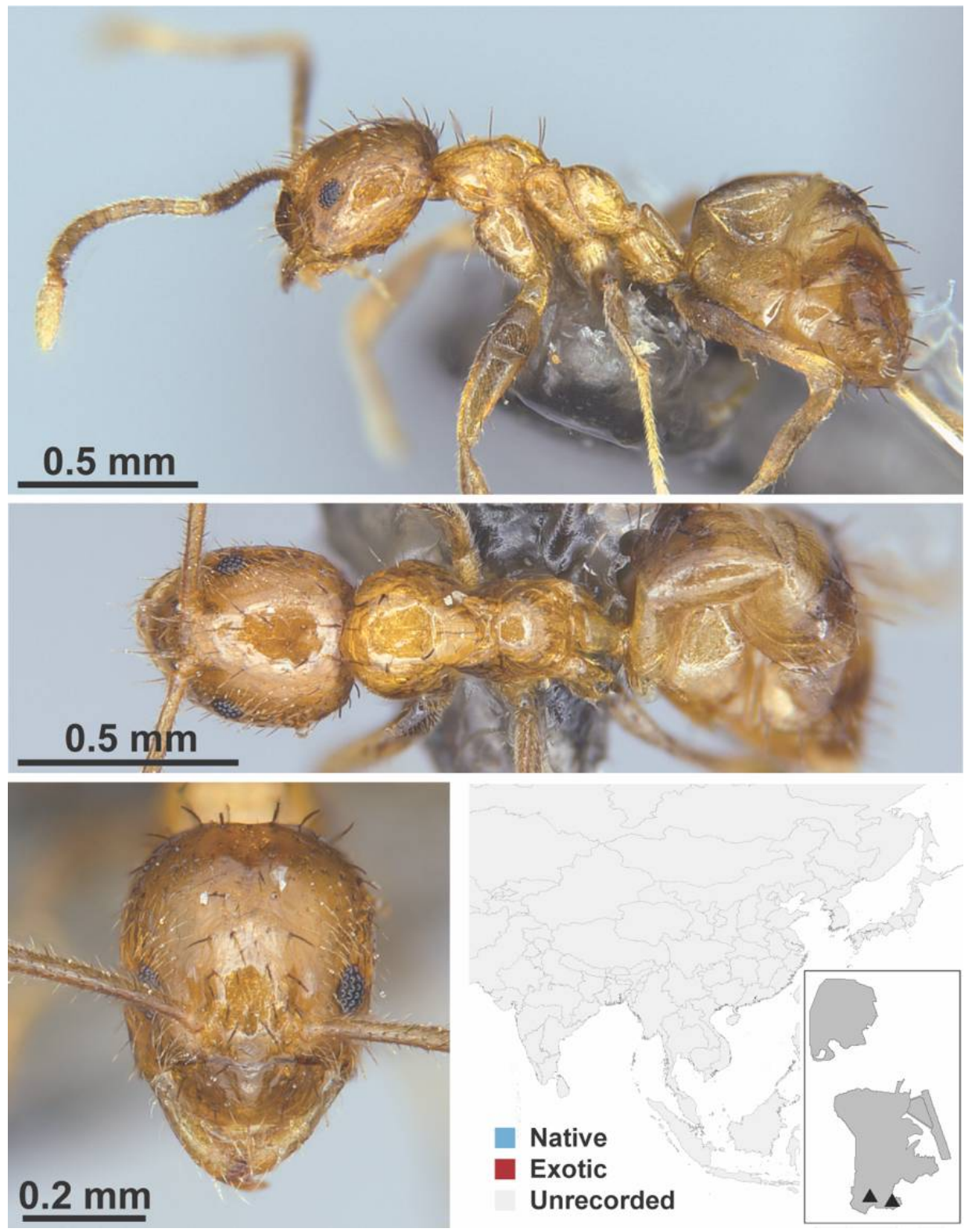

Figure A43. Nylanderia sp. 6 BG worker (MAC_S15_LLSP_sp.10, IBBL). 

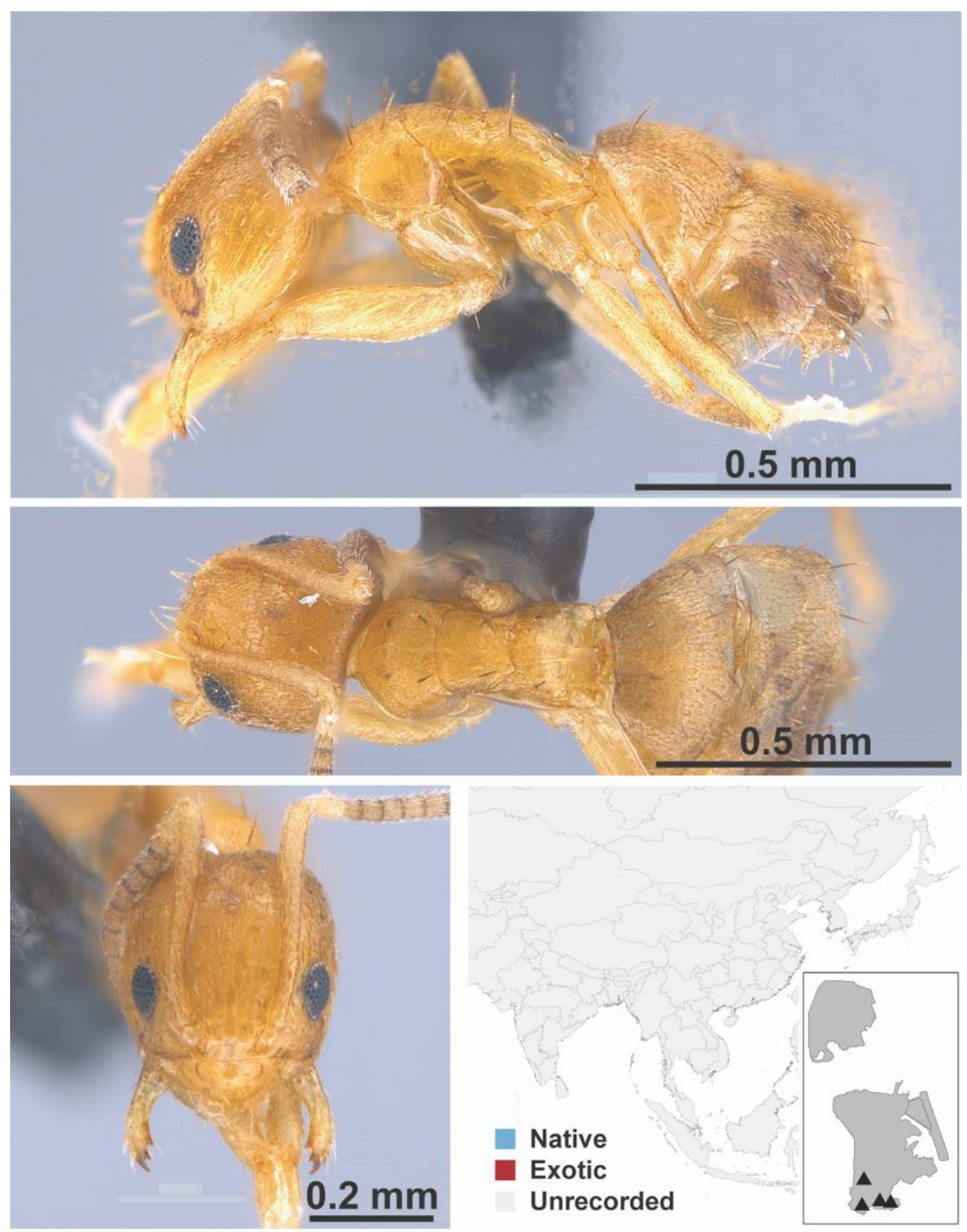

Figure A44. Paraparatrechina sp.1 BG Forel, 1913 worker (MAC_S18_q2_37.5_Sp.2, IBBL). 


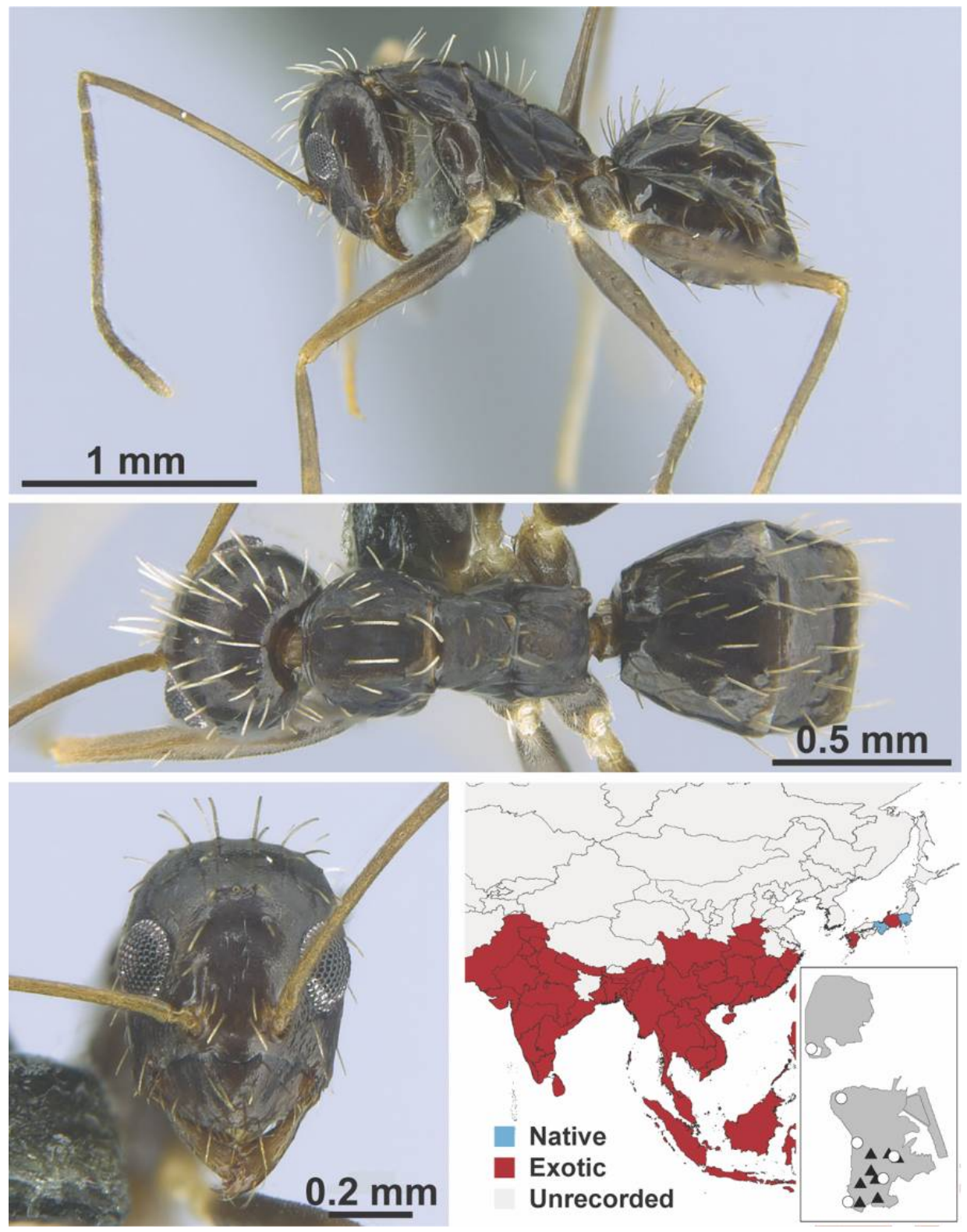

Figure A45. Paratrechina longicornis Latreille, 1802 worker (MAC_S11_LLSP_Sp.6, IBBL). 

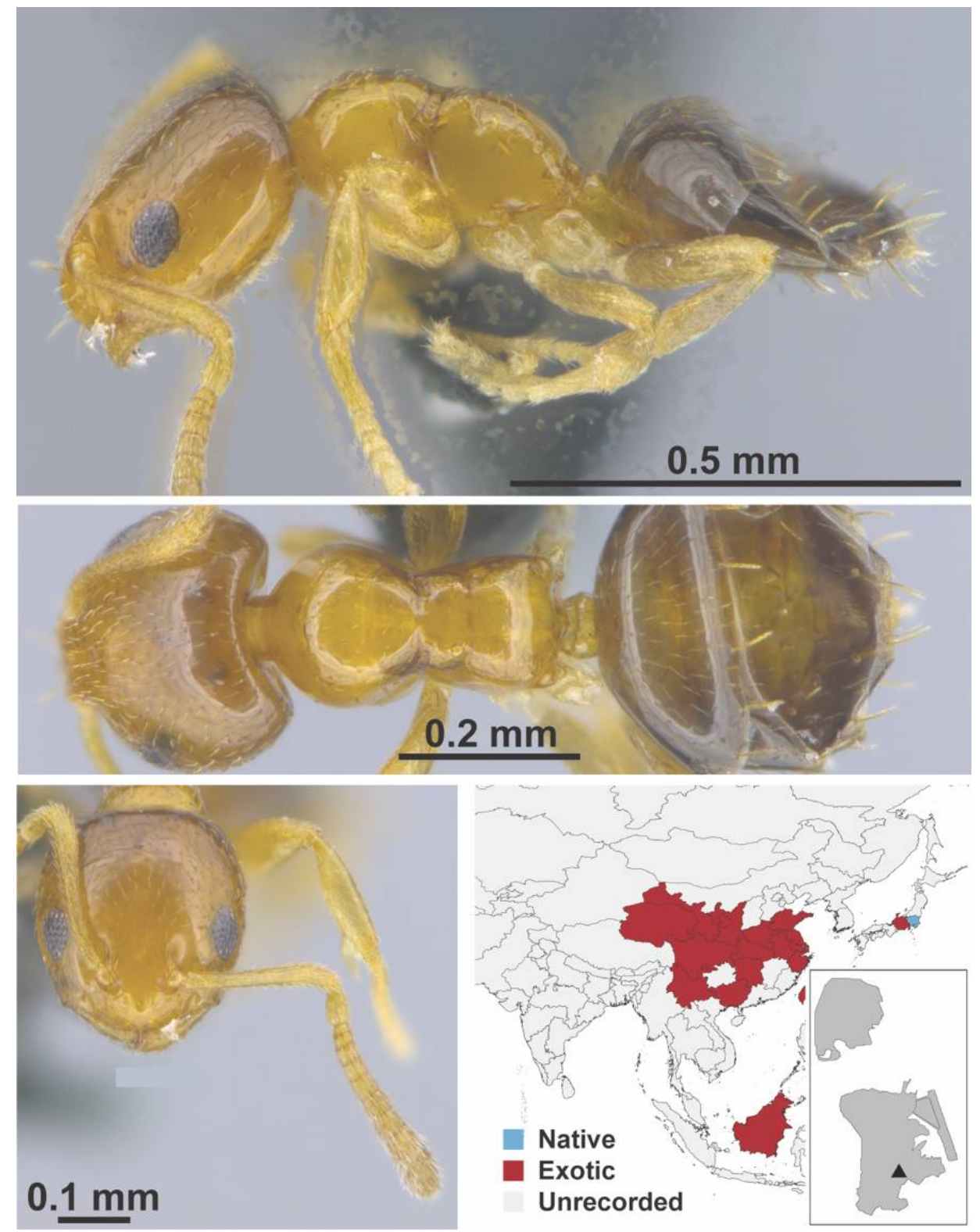

Figure A46. Plagiolepis alluaudi Emery, 1894 worker (MAC_S14_T2_2m_Sp.1, IBBL). 


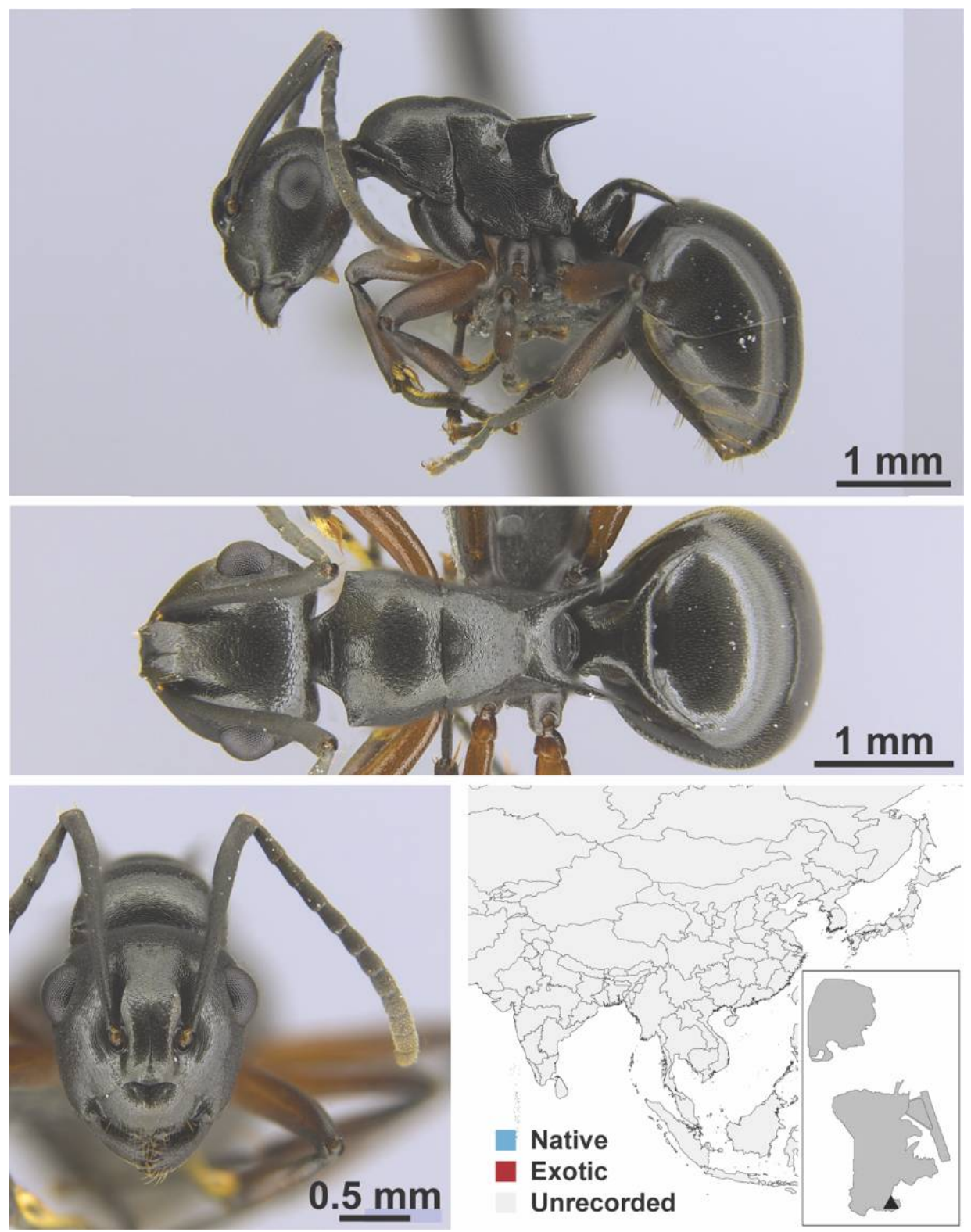

Figure A47. Polyrhachis confusa Emery, 1893 worker (FB19152, IBBL). 


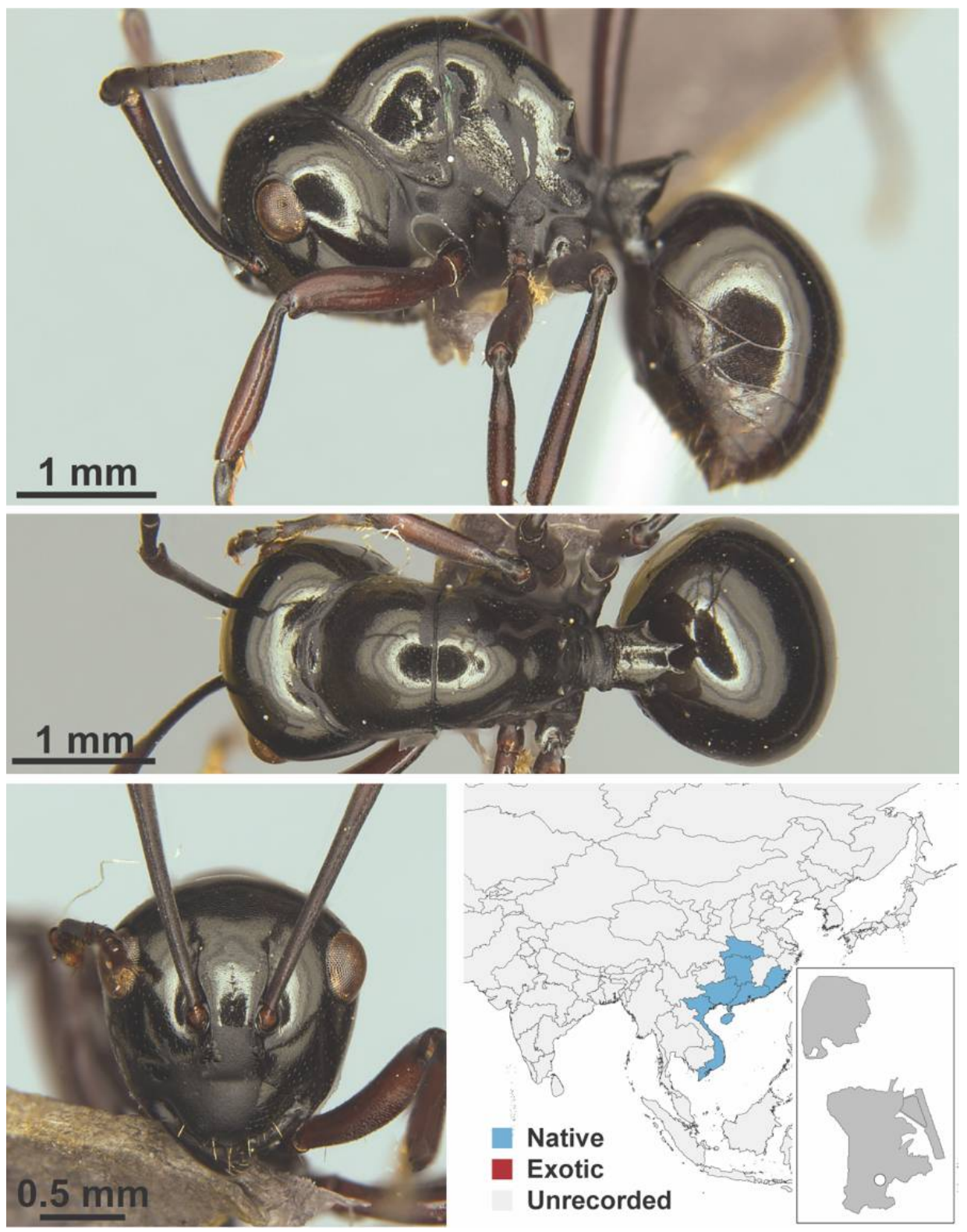

Figure A48. Polyrhachis demangei Santschi, 1910 worker (Polyrhachis demangei, CML collection). 


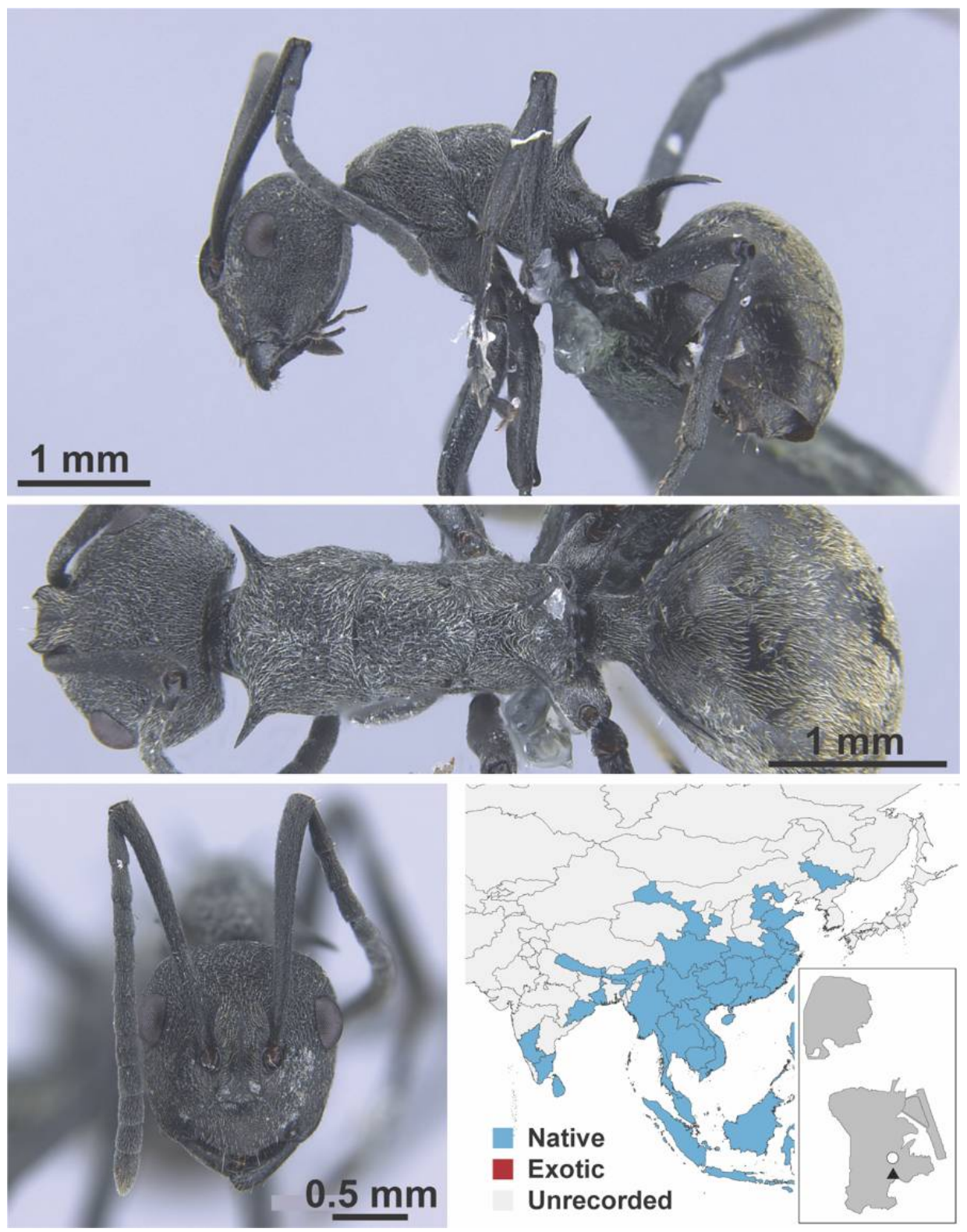

Figure A49. Polyrhachis dives Smith, 1857 worker (MAC_S03_HC_01_Sp.2, IBBL). 

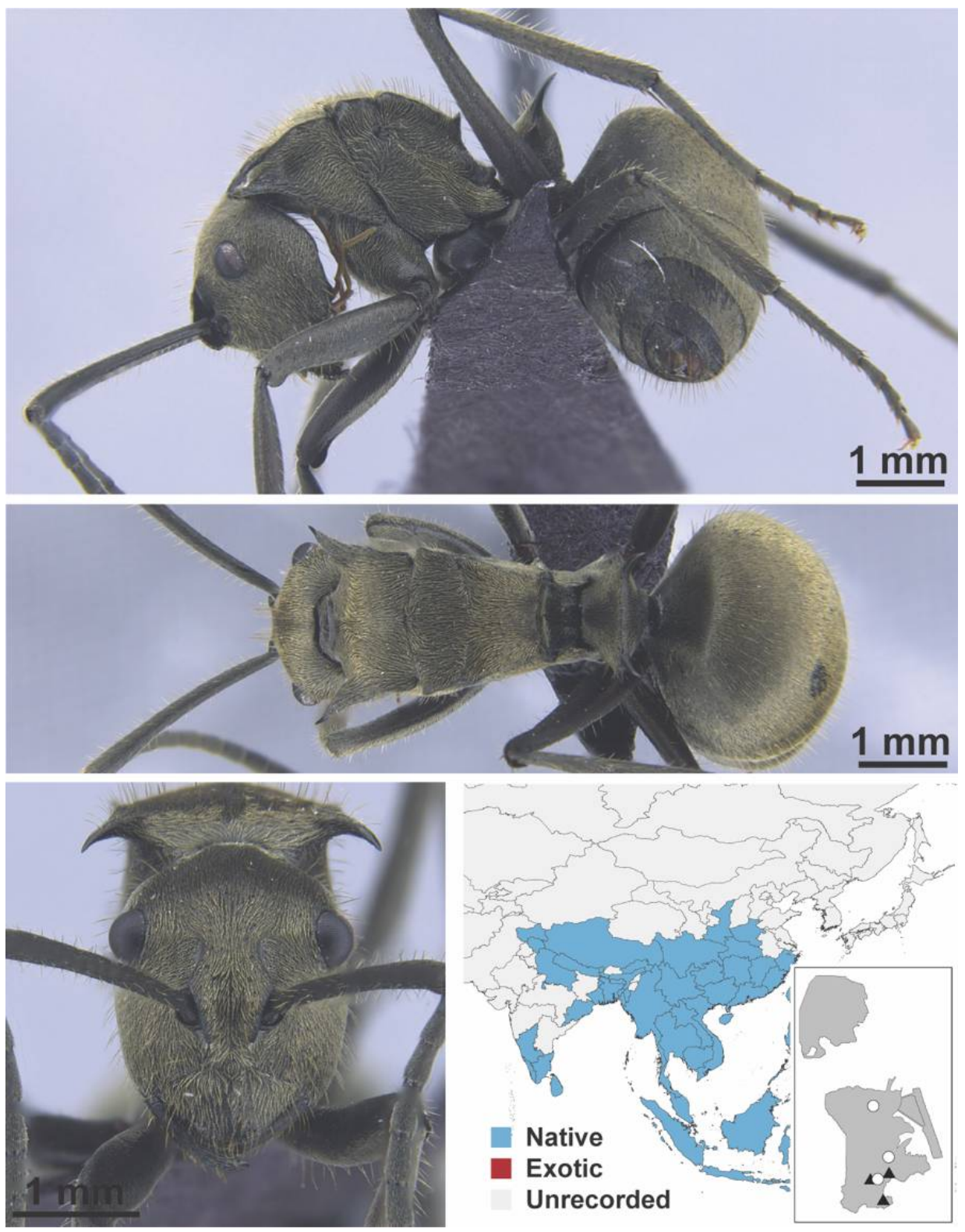

Figure A50. Polyrhachis illaudata Walker, 1859 worker (MAC_S03_HC_01_Sp.1, IBBL). 

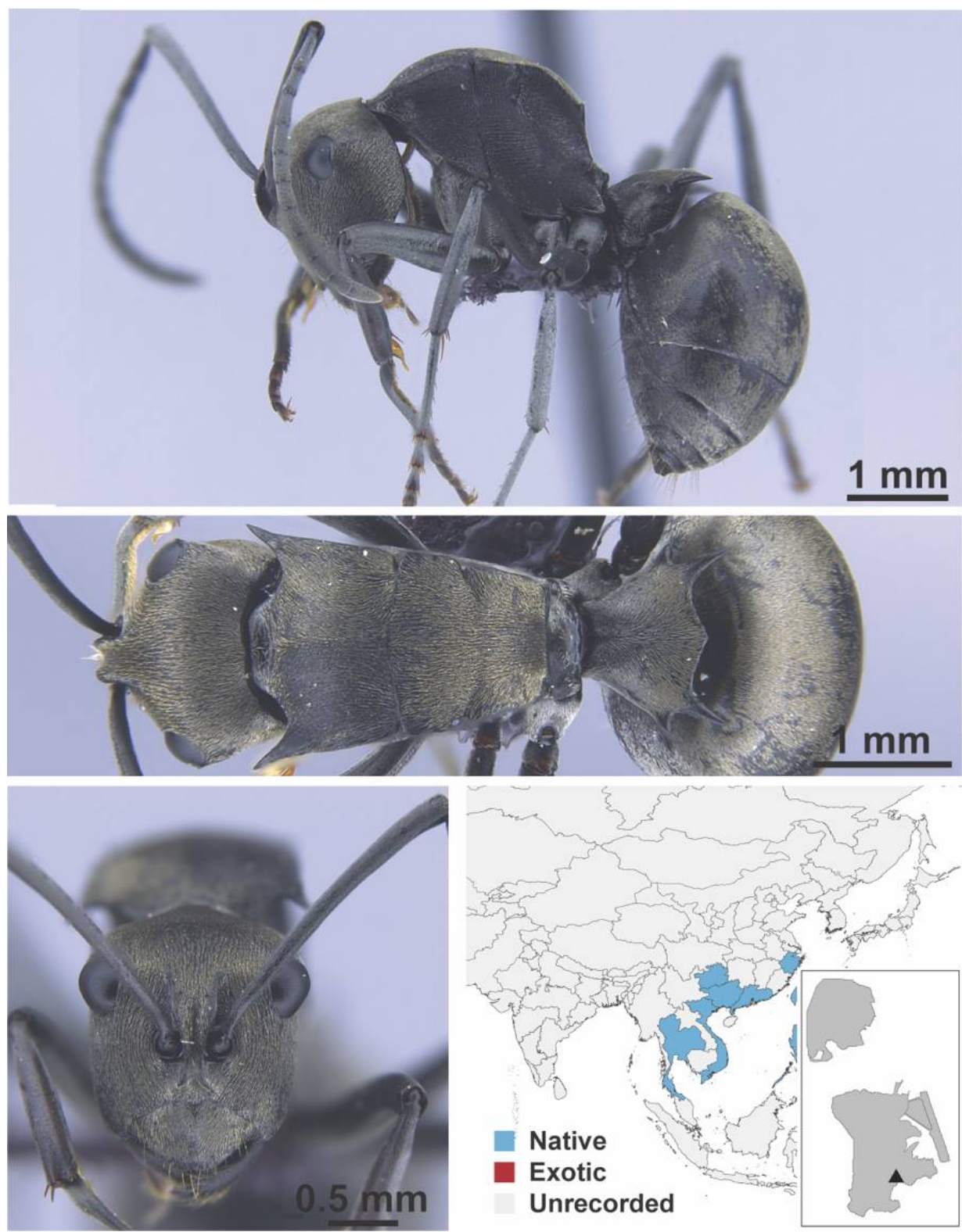

Figure A51. Polyrhachis latona Wheeler, 1909 worker (MAC_S03_LLSA_Sp.5, IBBL). 


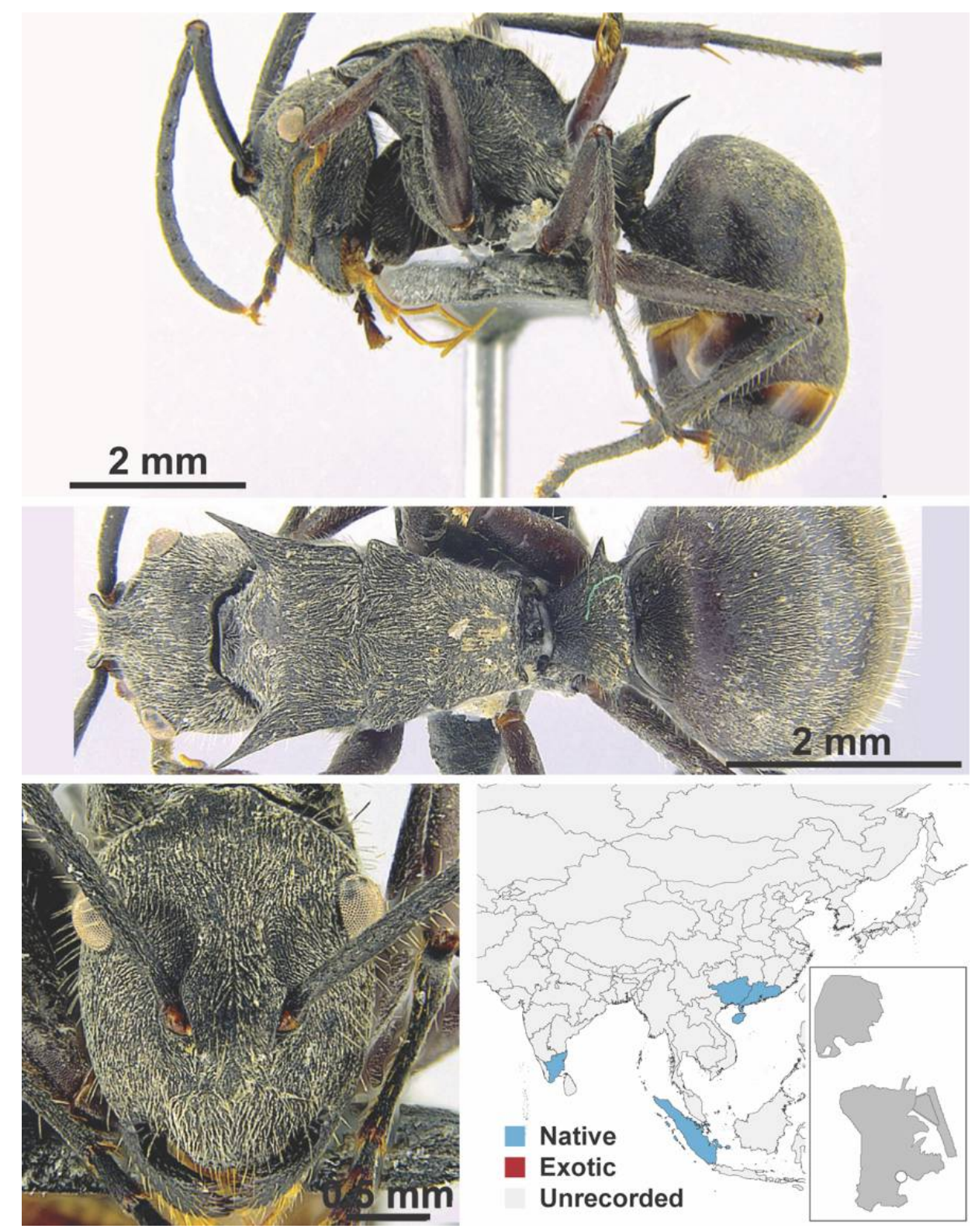

Figure A52. Polyrhachis tyrannica Smith, 1858 worker (K6558(2)). Species images taken from Wong and Guénard 2020 [55] with permission. 

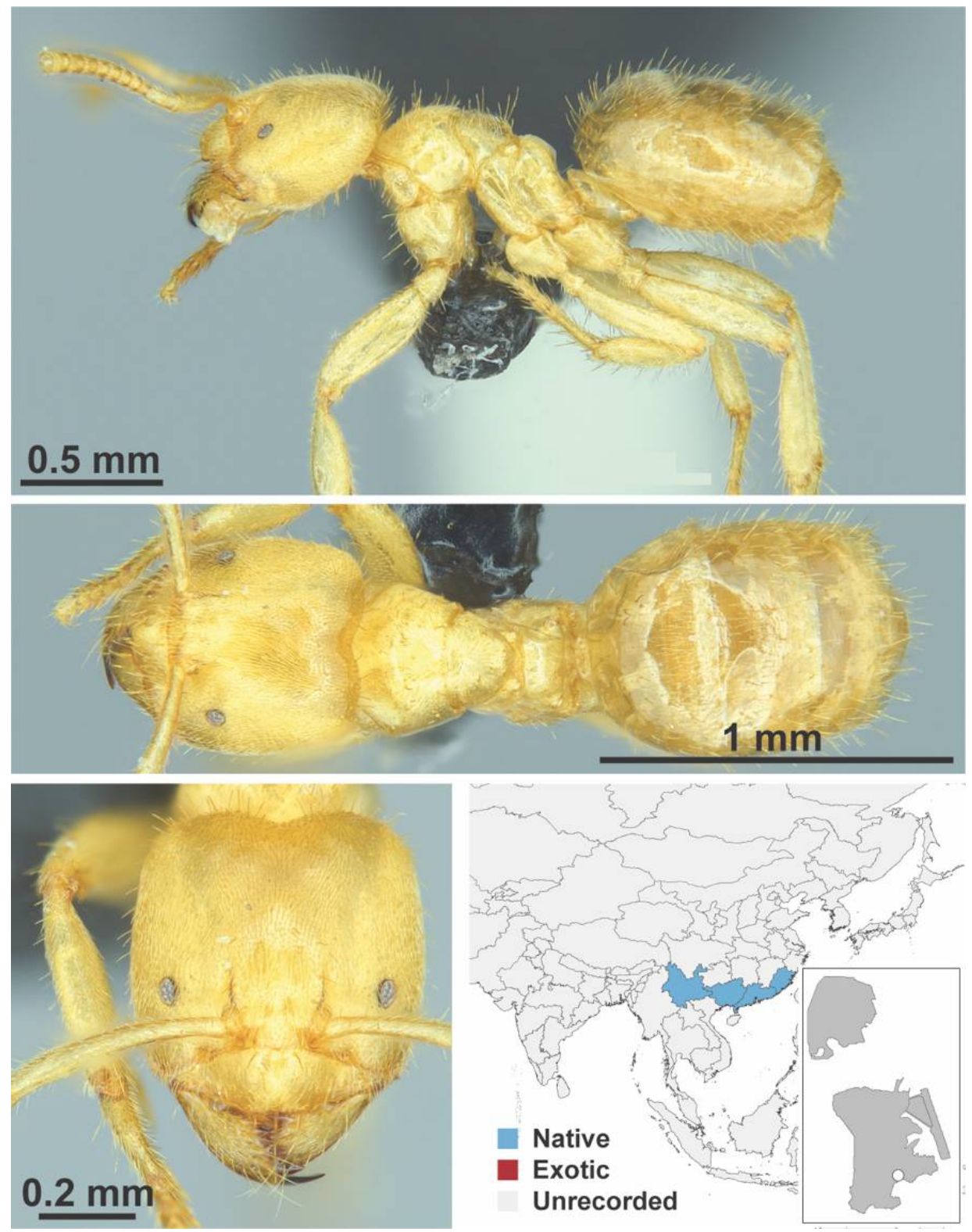

Figure A53. Pseudolasius risii Forel, 1894 worker (Pseudolasius risii, CML collection). 
Appendix A.5 LEPTANILLINAE
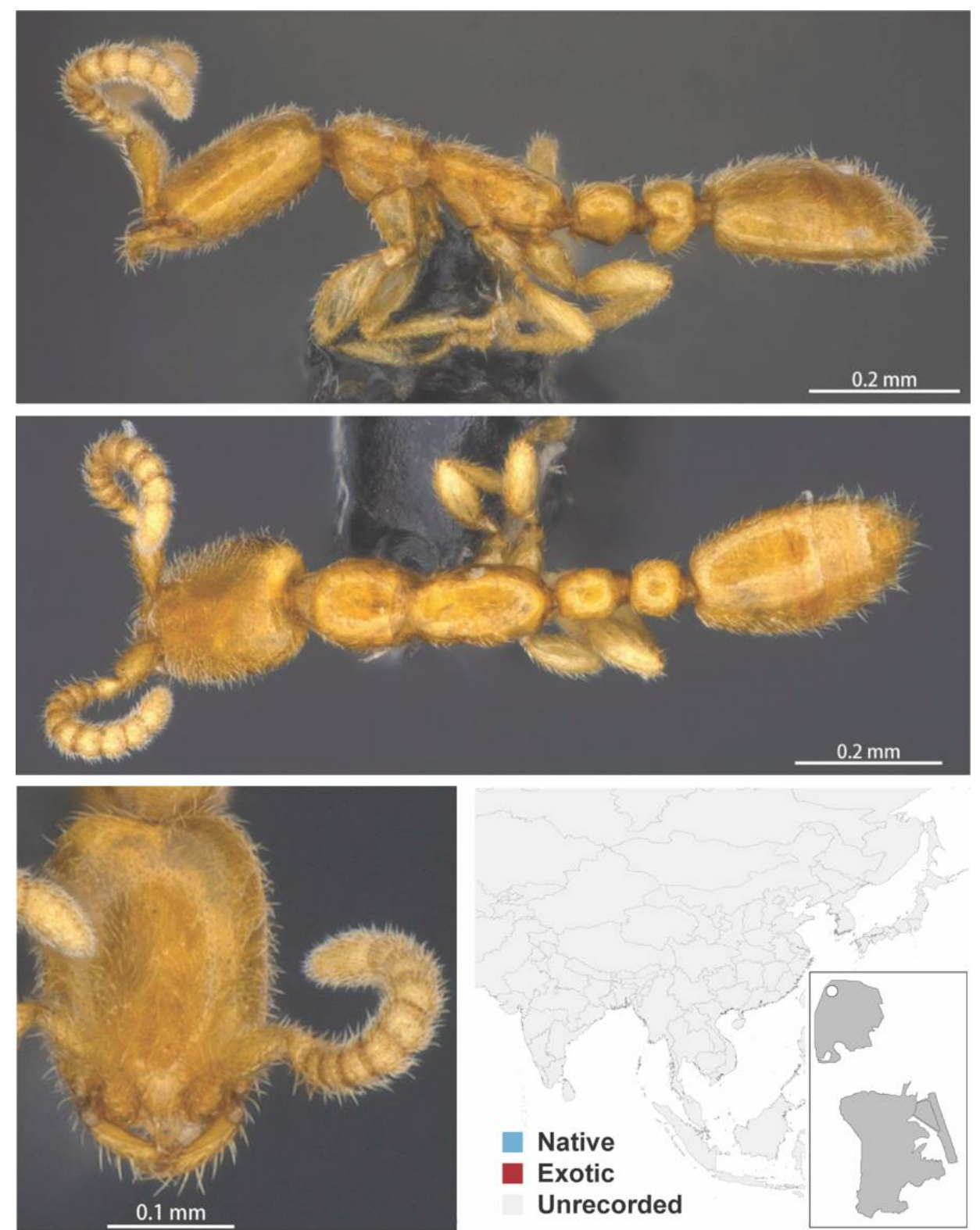

Figure A54. Leptanilla macaoensis Leong, Yamane \& Guénard, 2018 worker (LCM00039, IBBL). Species images taken from Leong, Yamane \& Guénard, 2018 [61] with permission. 


\section{Appendix A.6 MYRMICINAE}
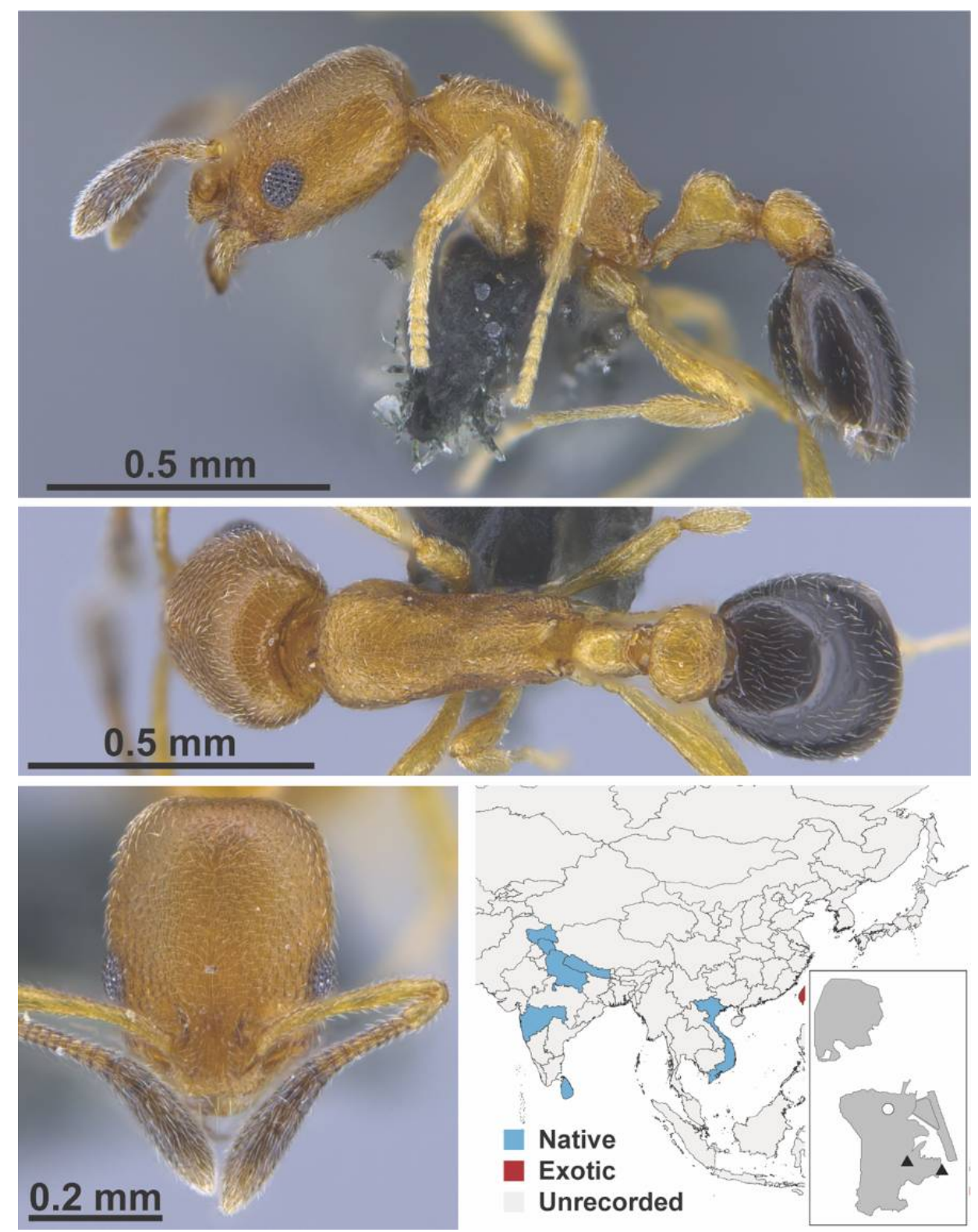

Figure A55. Cardicondyla minutior Forel, 1899 worker (MAC_S04_LLSP_sp.6, IBBL). 


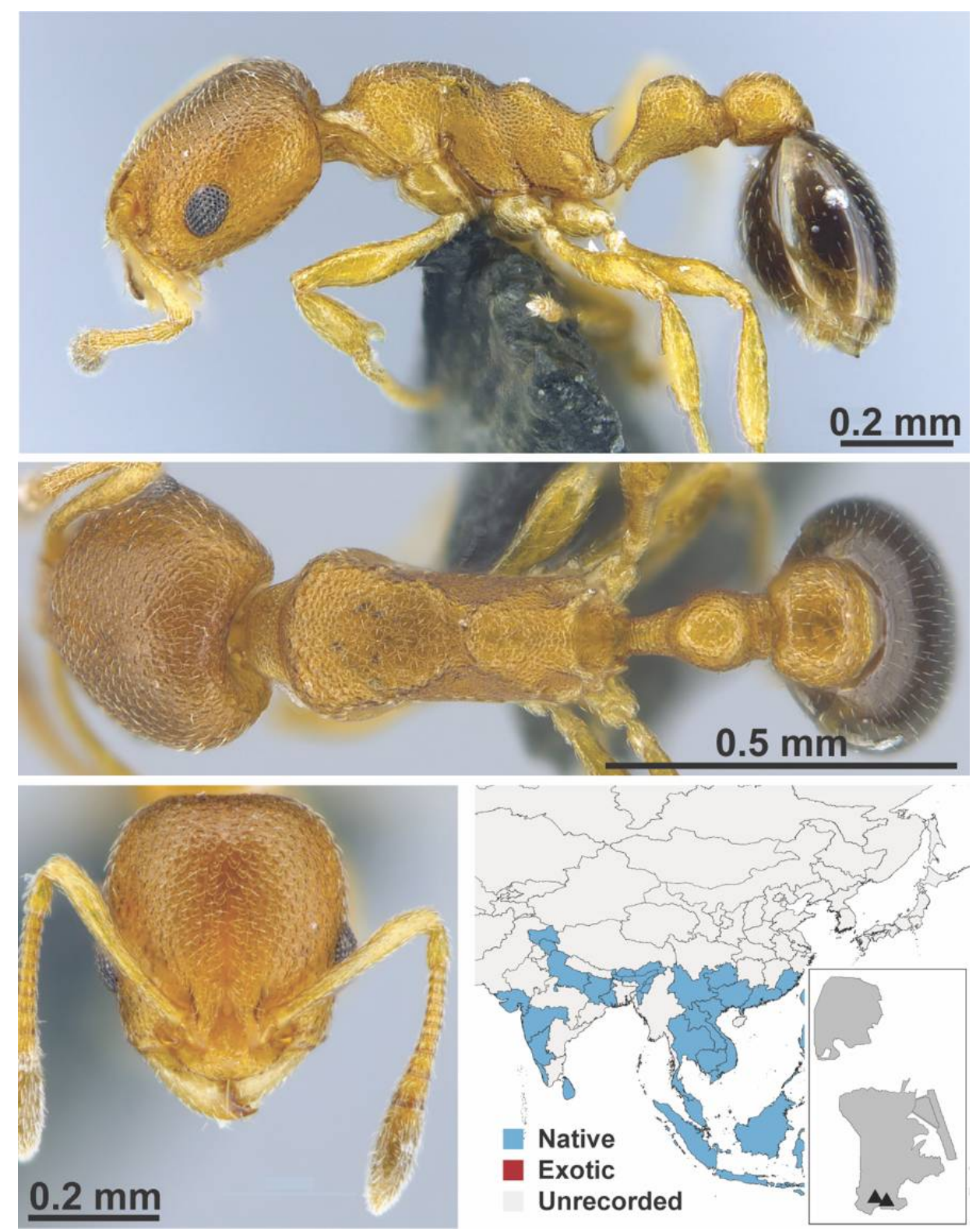

Figure A56. Cardiocondyla wroughtonii Forel, 1890 worker (MAC_S11_T3_3m_sp.4, IBBL). 

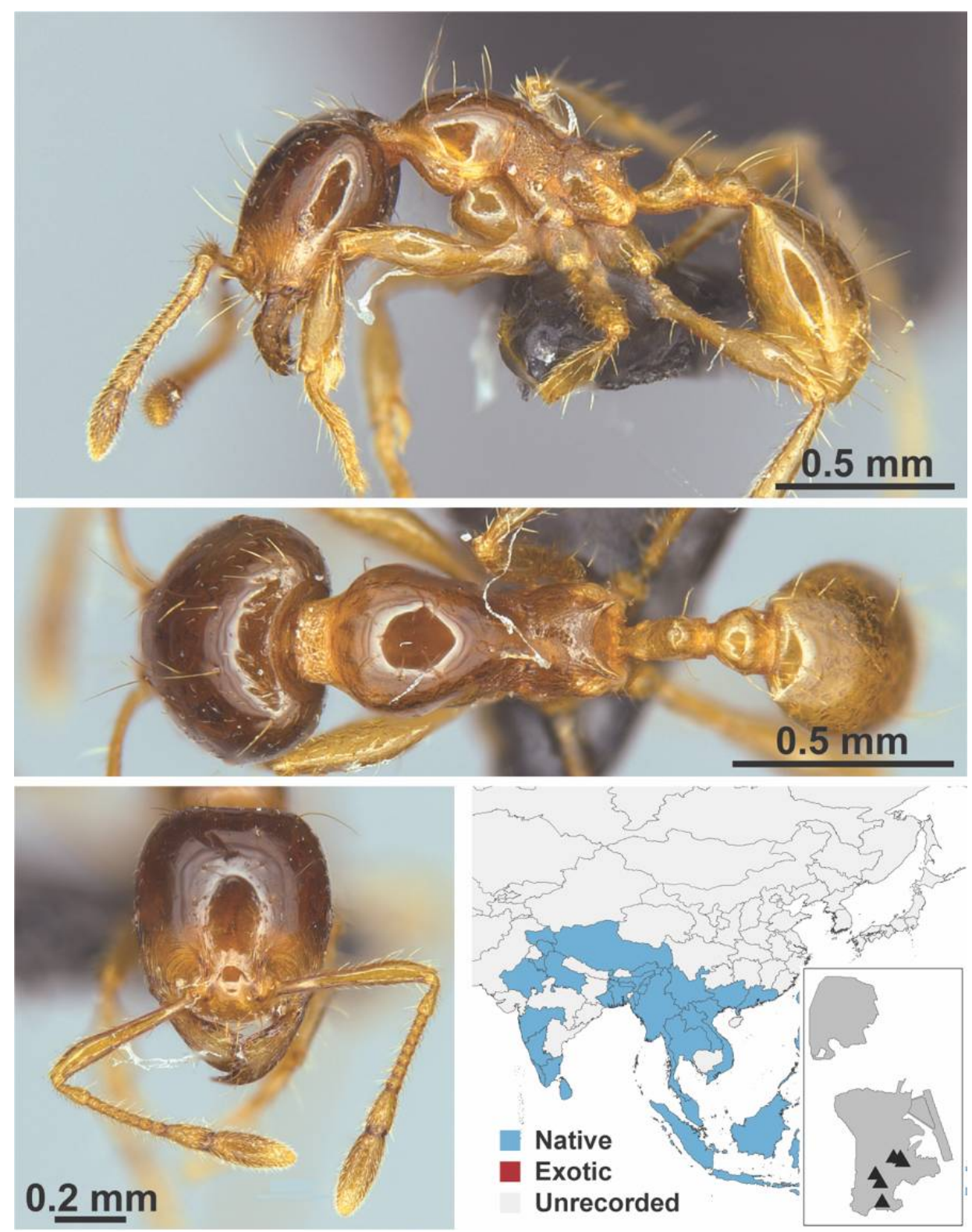

Figure A57. Carebara affinis Jerdon, 1851 worker (MAC_S9_37.5_q2_sp.1, IBBL). 


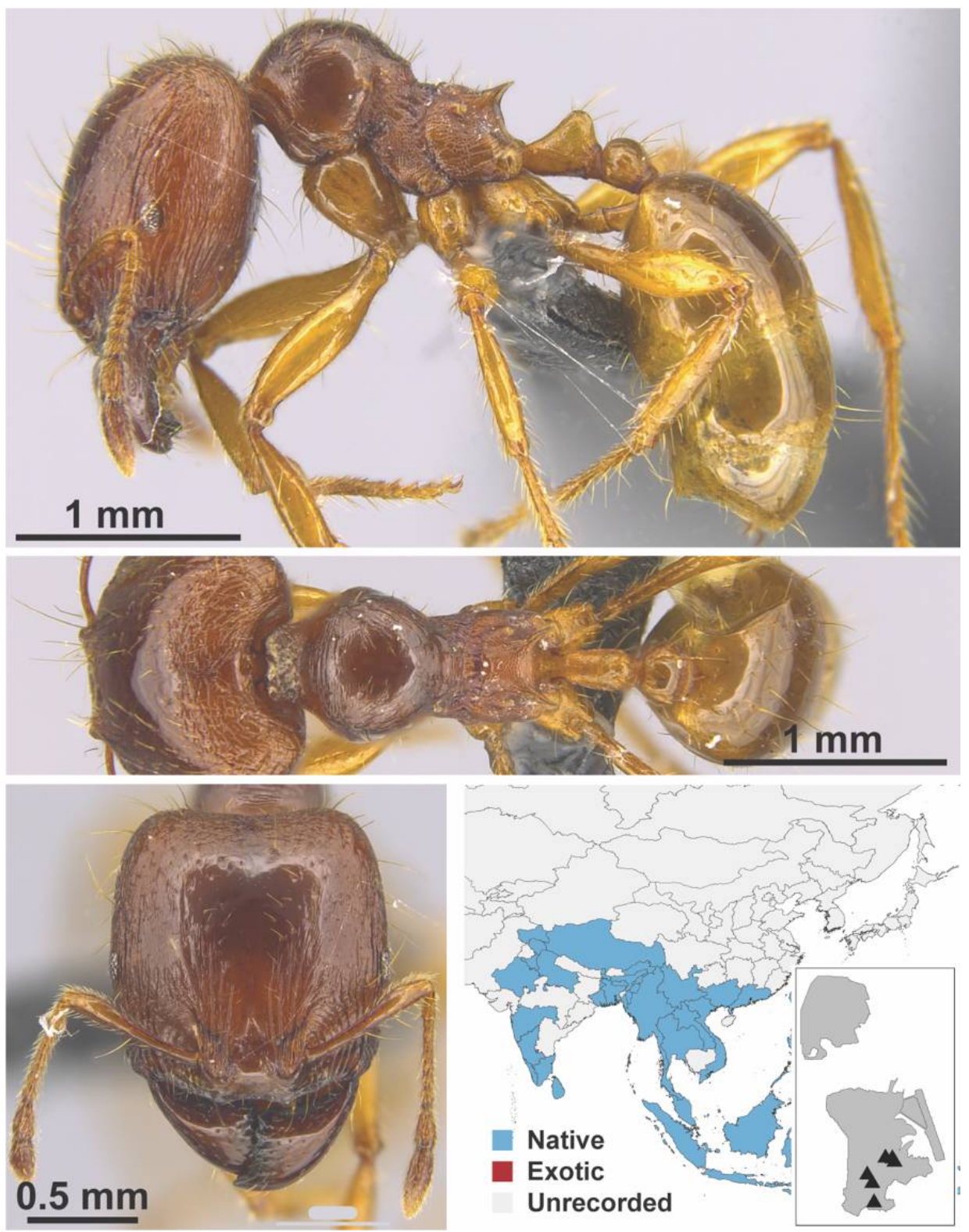

Figure A58. Carebara affinis Jerdon, 1851 major (MAC_S8_25_q1_sp.1, IBBL). 

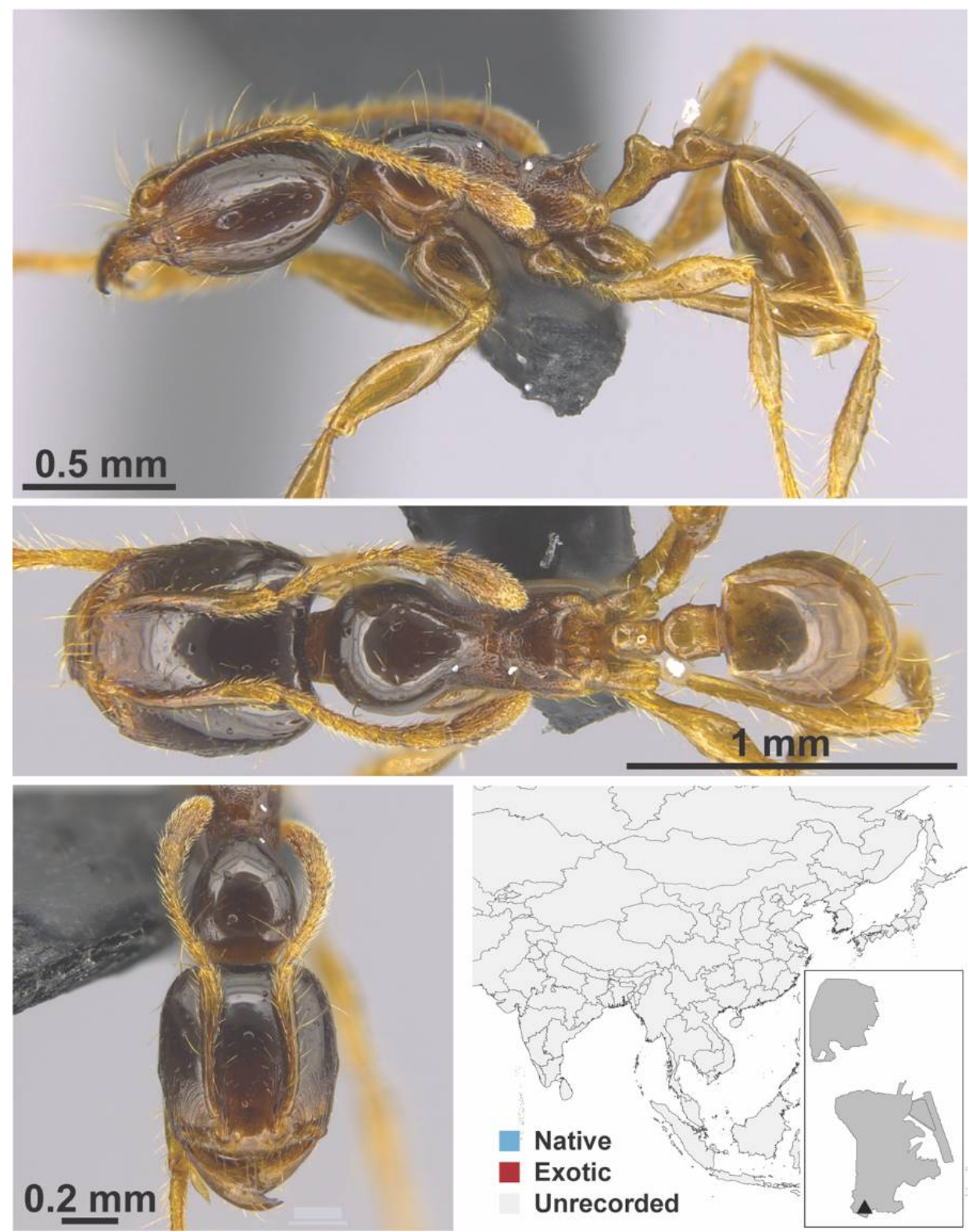

Figure A59. Carebara nr. diversa Jerdon, 1851 worker (MAC_S18_q2_37.5_sp.3, IBBL). 


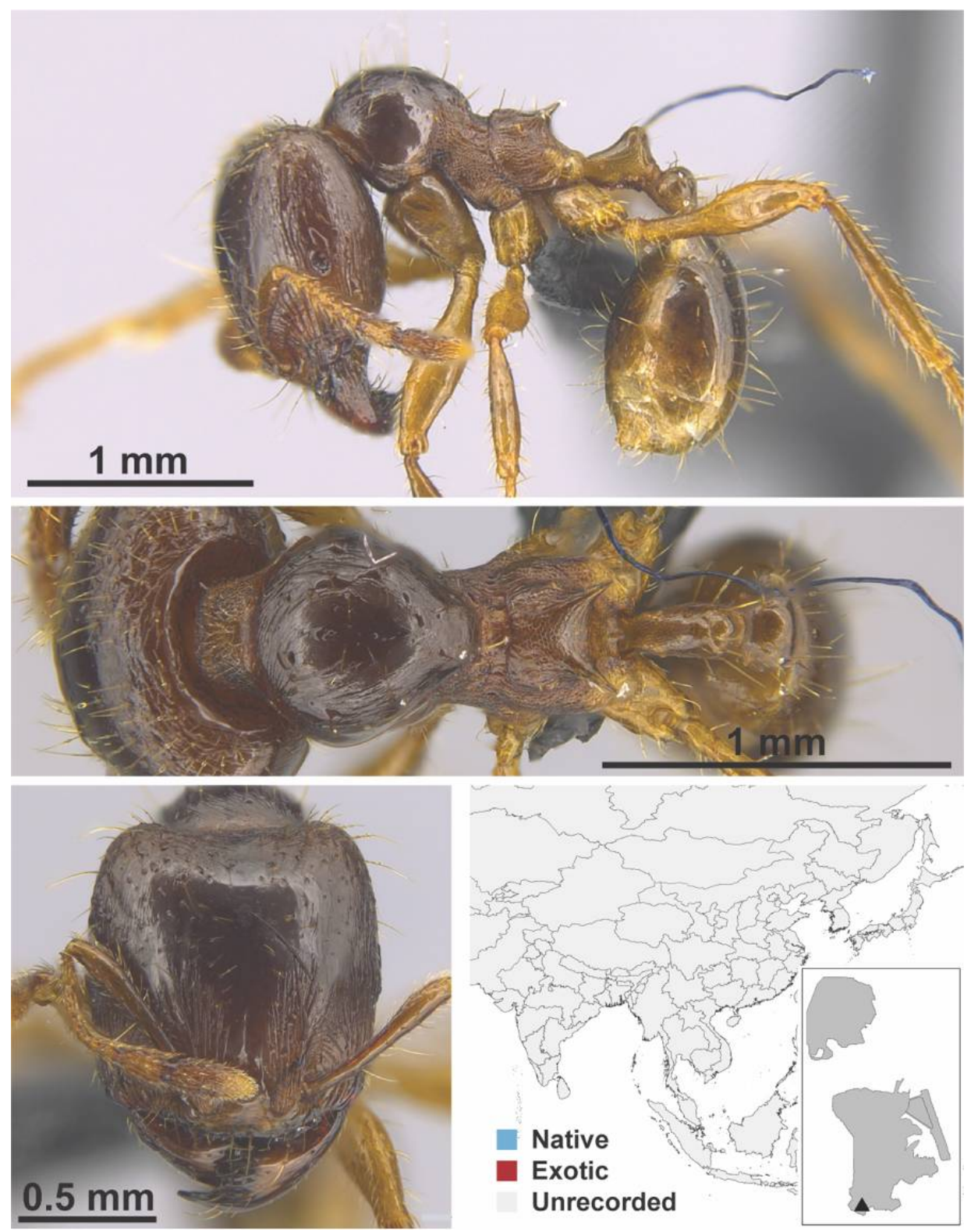

Figure A60. Carebara nr. diversa Jerdon, 1851 major (MAC_S18_q2_37.5_sp.3, IBBL). 

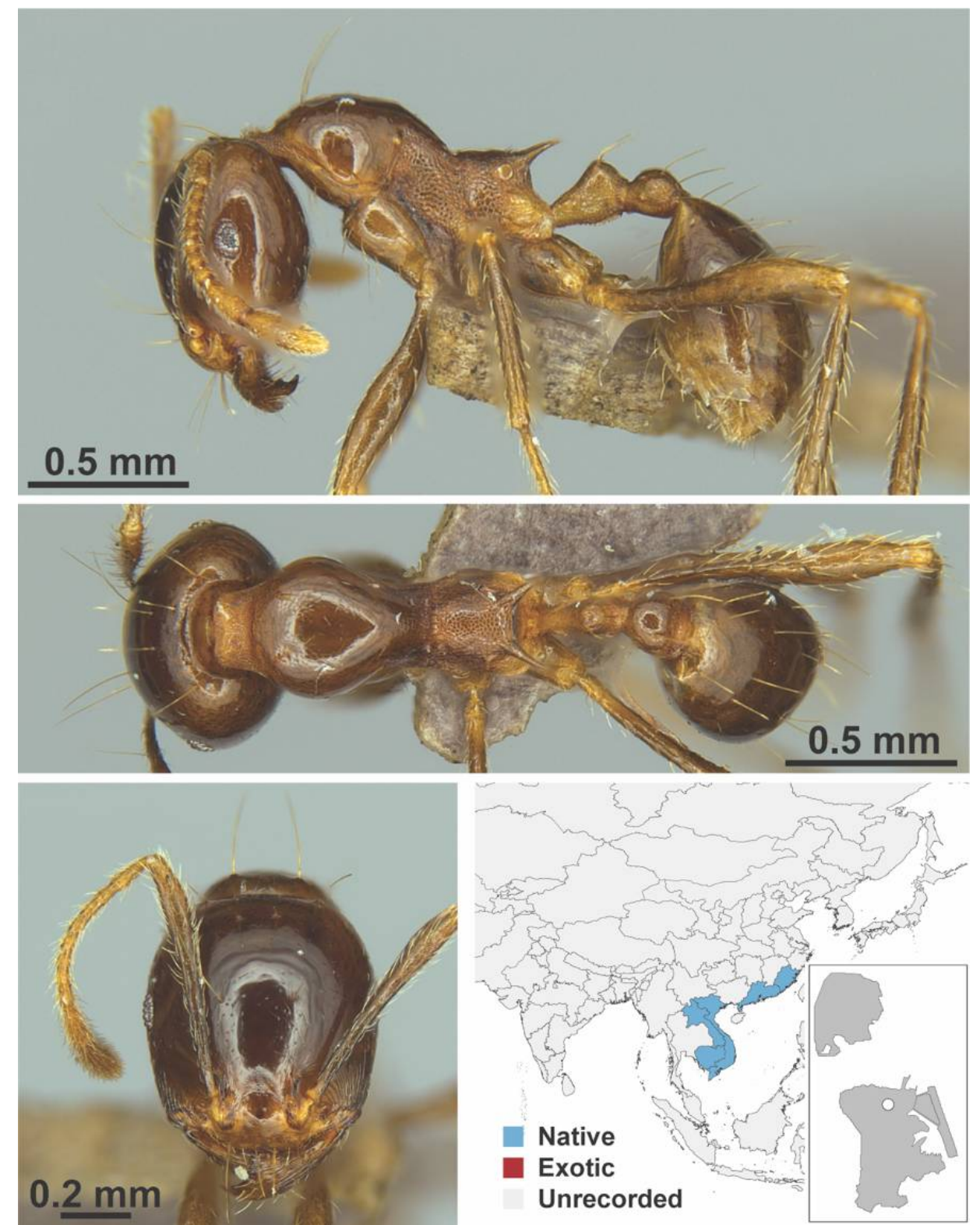

Figure A61. Carebara diversa laotina, Santschi, 1921 worker (Carebara diversa laotina, CML collection). 


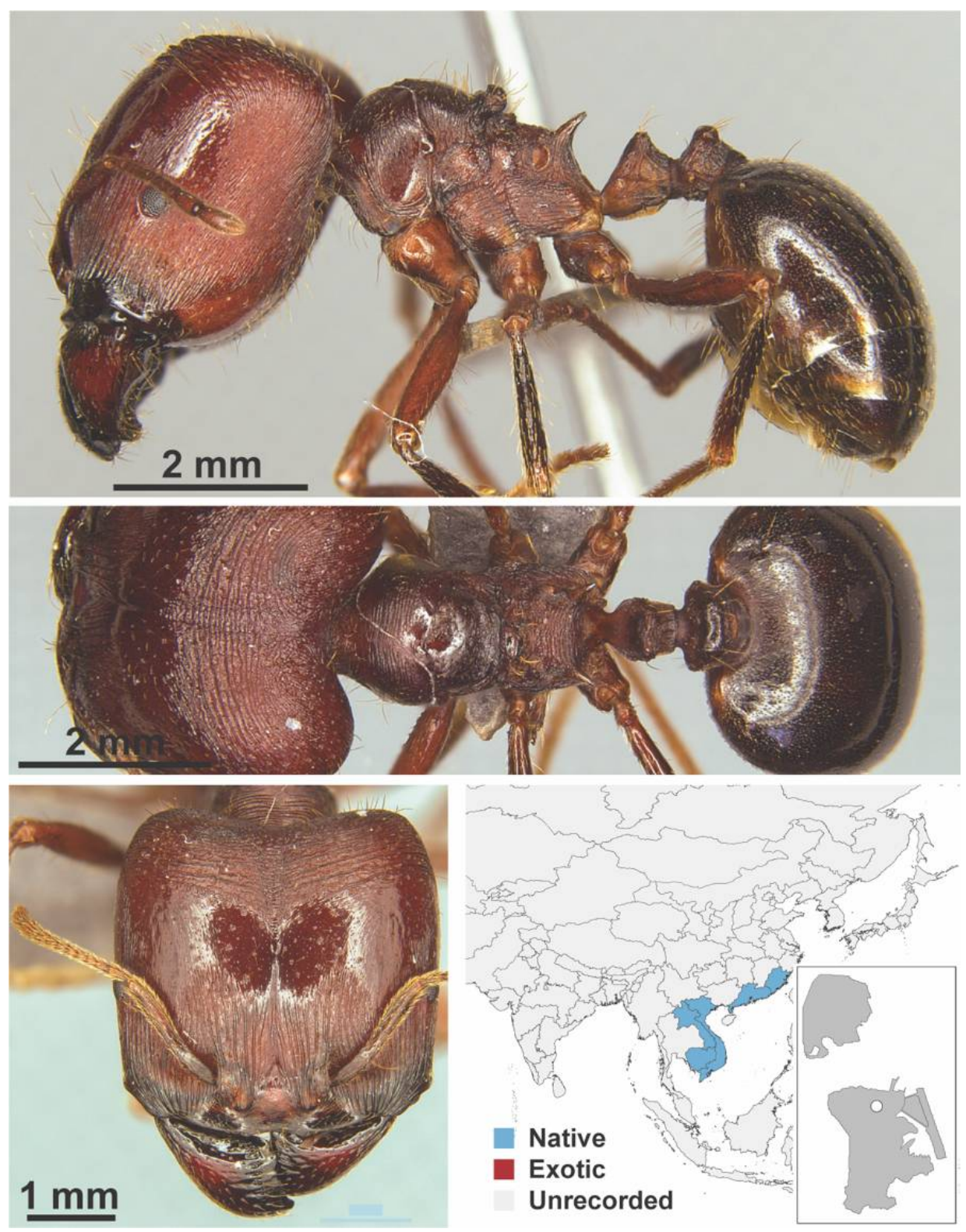

Figure A62. Carebara diversa laotina, Santschi, 1921 major (Carebara diversa laotina, CML collection). 


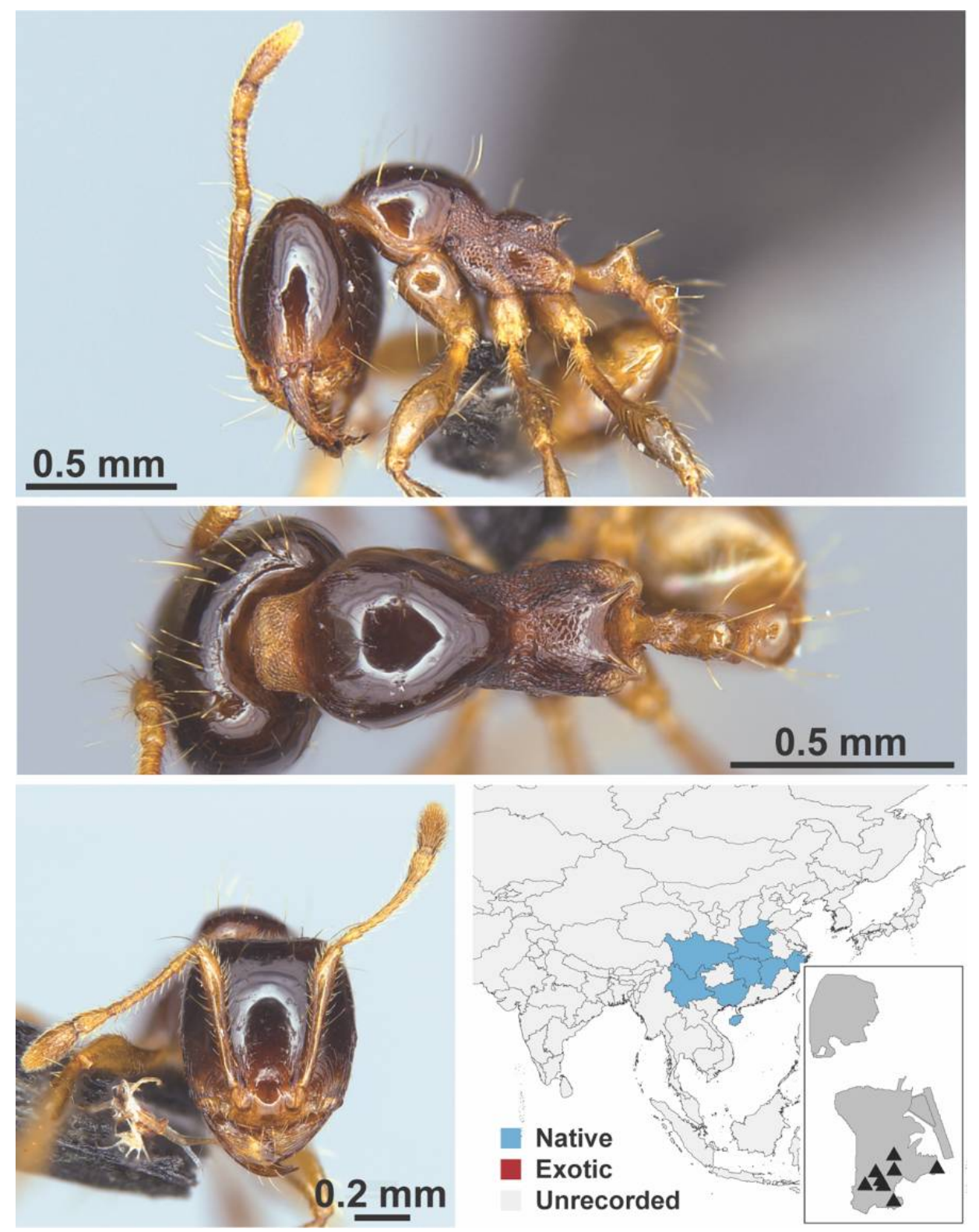

Figure A63. Carebara melasolena Zhou \& Zheng, 1997 worker (MAC_S12_LLSA_sp.1, IBBL). 


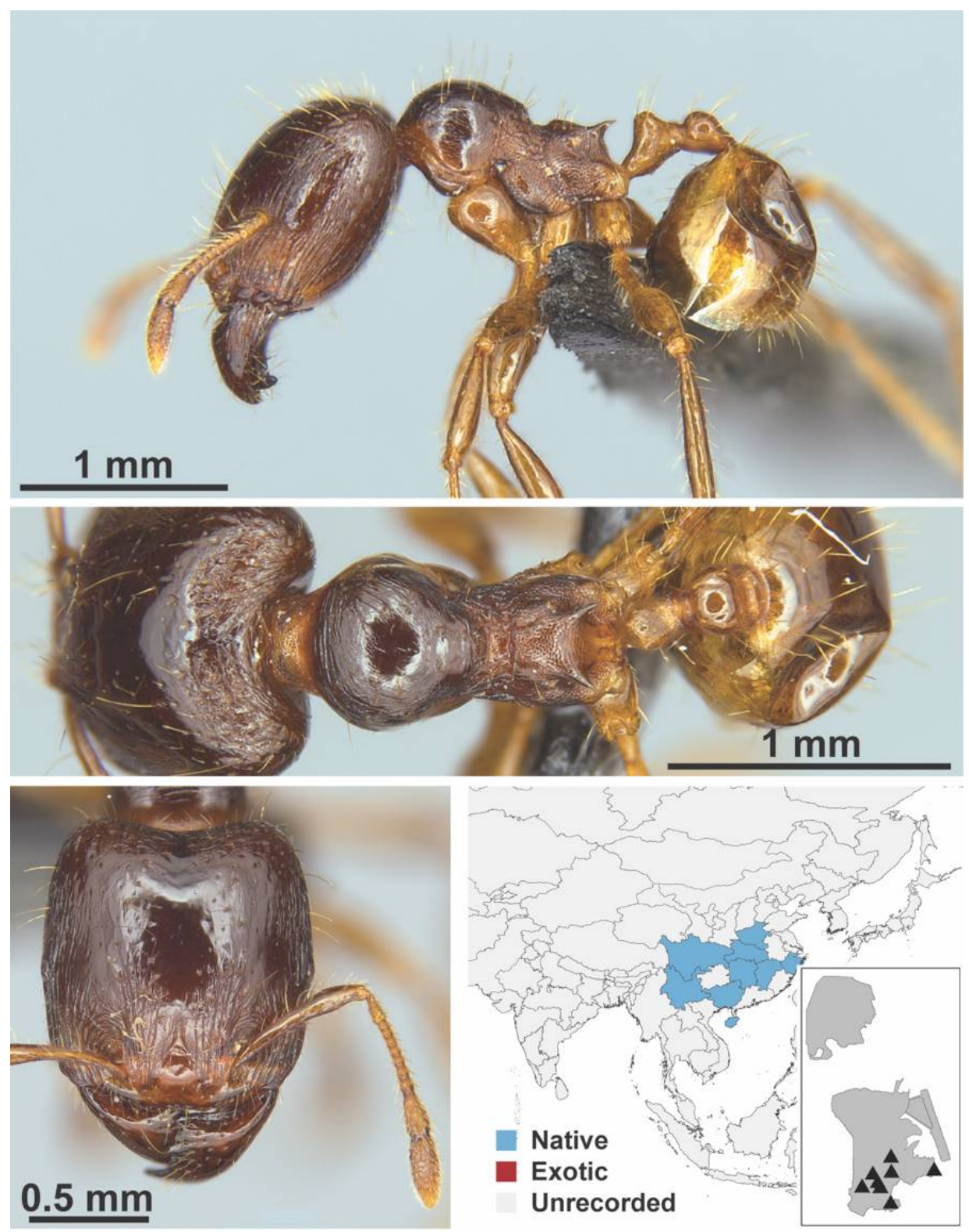

Figure A64. Carebara melasolena Zhou \& Zheng, 1997 major (MAC_S12_LLSA_sp.1, IBBL). 

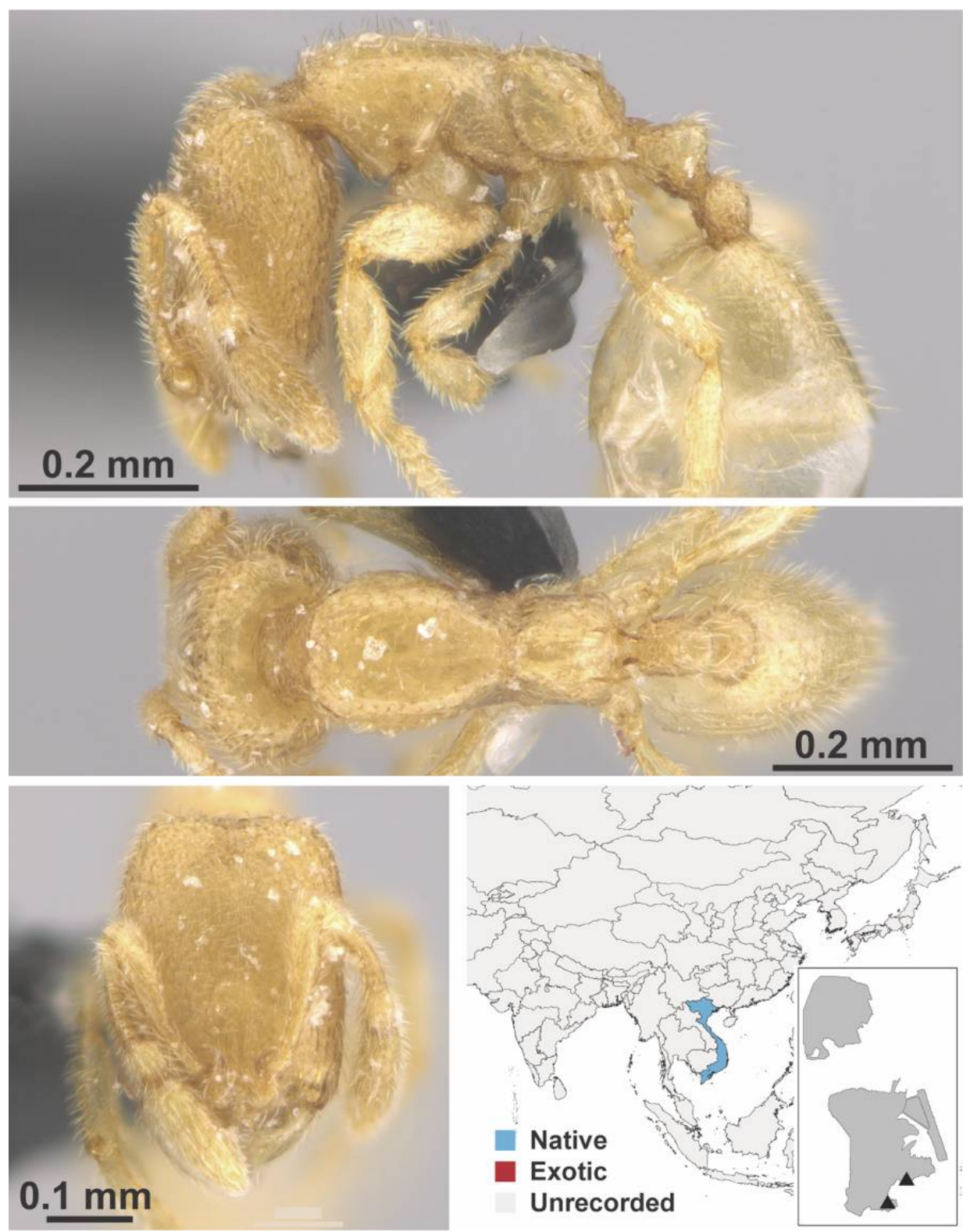

Figure A65. Carebara sangi Eguchi \& Bui, 2007 worker (MAC_S13_q1_25_Sp.2, IBBL). 

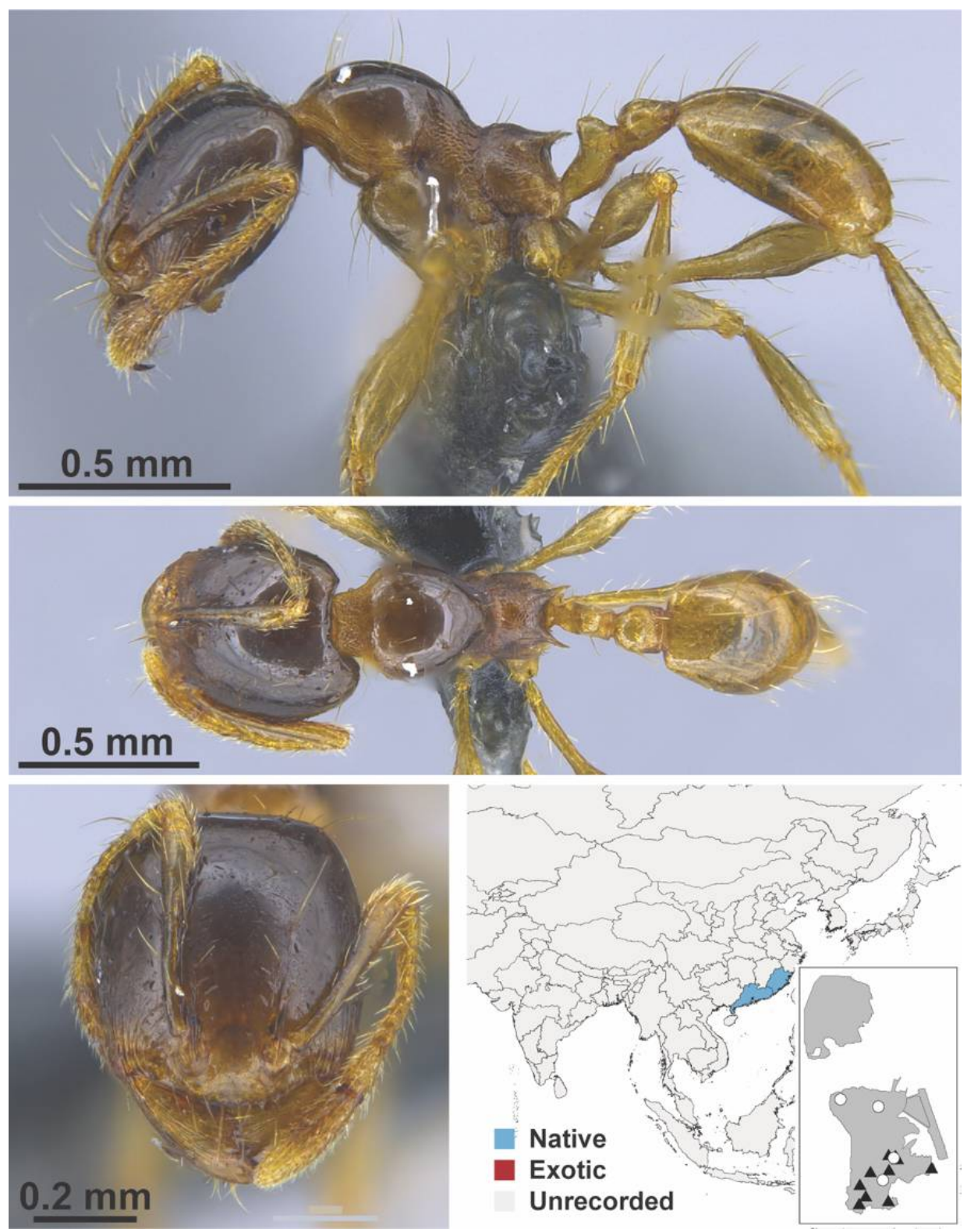

Figure A66. Carebara zengchengensis Zhou, Zhao \& Jia, 2006 worker (MAC_S12_q3_37.5_Sp.4, IBBL). 


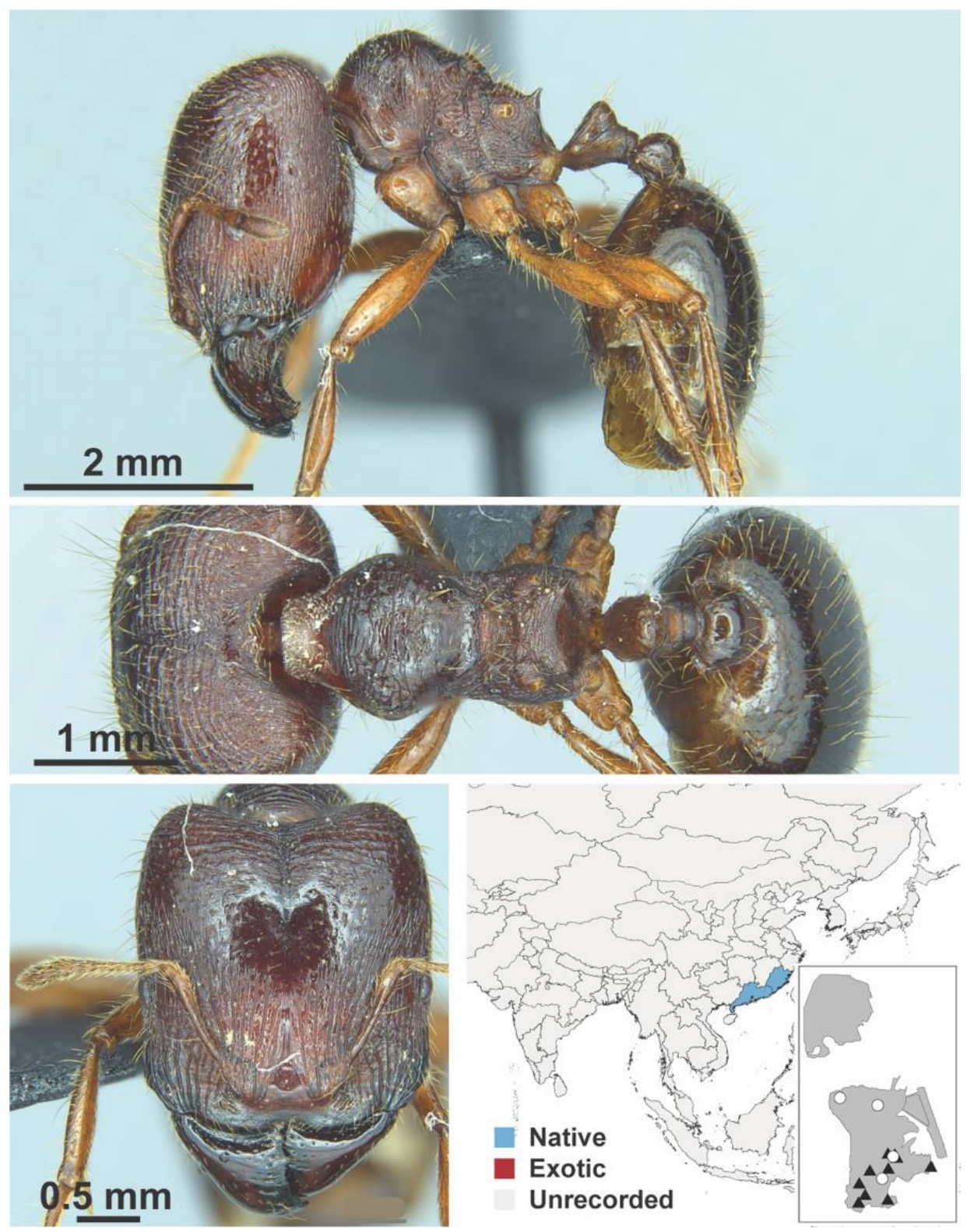

Figure A67. Carebara zengchengensis Zhou, Zhao \& Jia, 2006 worker (MAC_S12_q3_37.5_Sp.4, IBBL). 

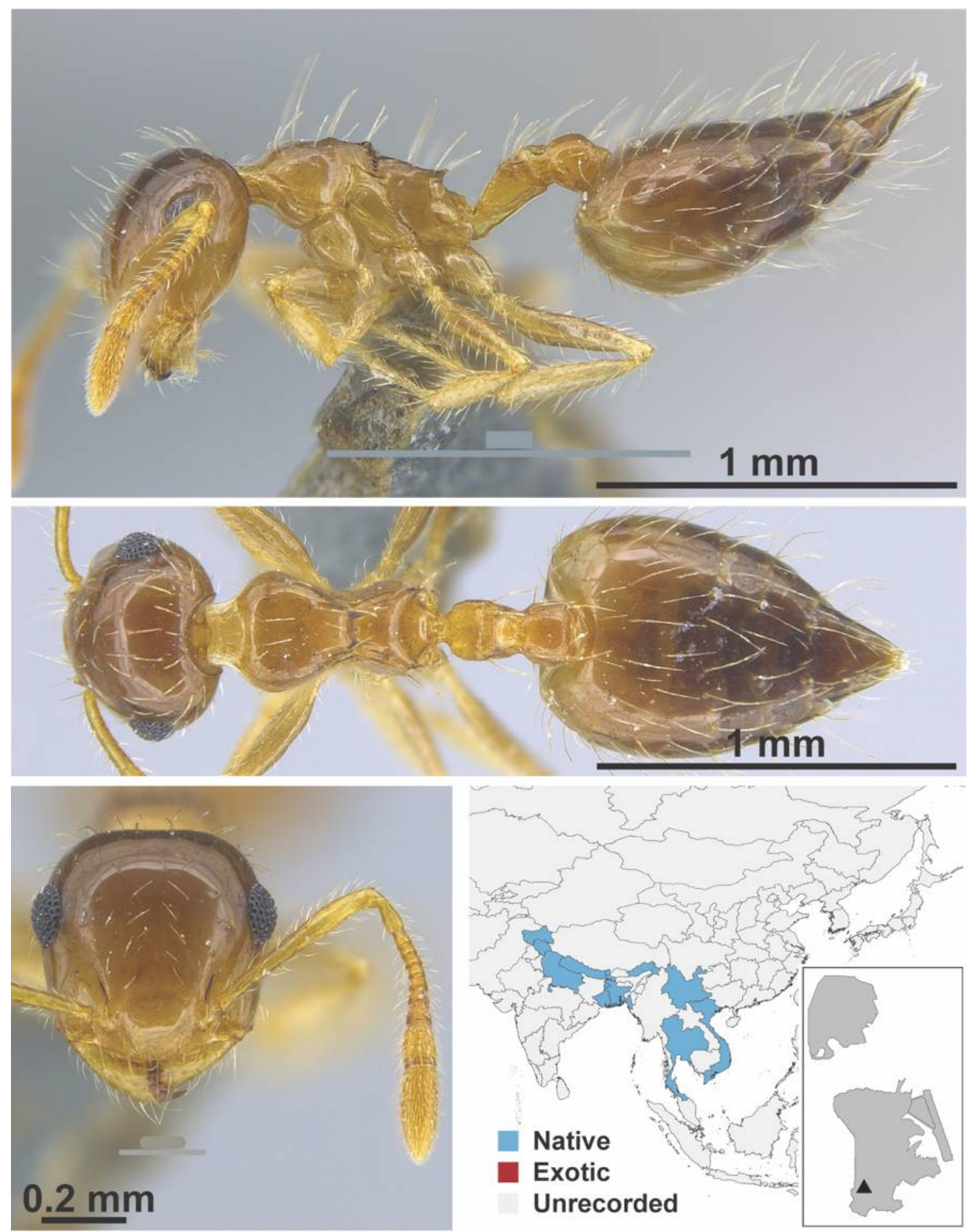

Figure A68. Crematogaster binghamii Forel, 1904 worker (MAC_S21_B08_sp.1, IBBL). 

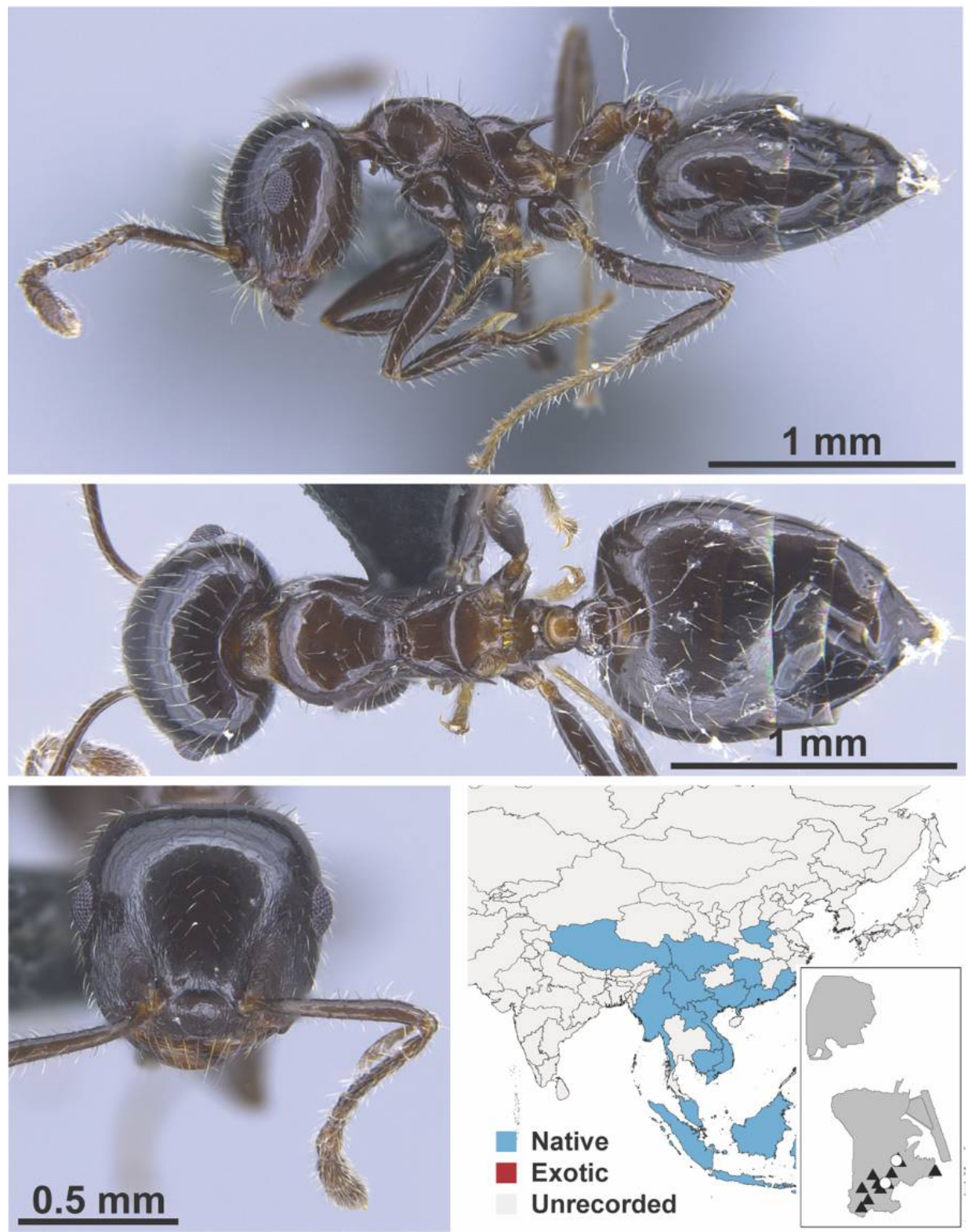

Figure A69. Crematogaster ferrarii Emery, 1888 worker (MAC_S01_LLSP_Sp.7, IBBL). 

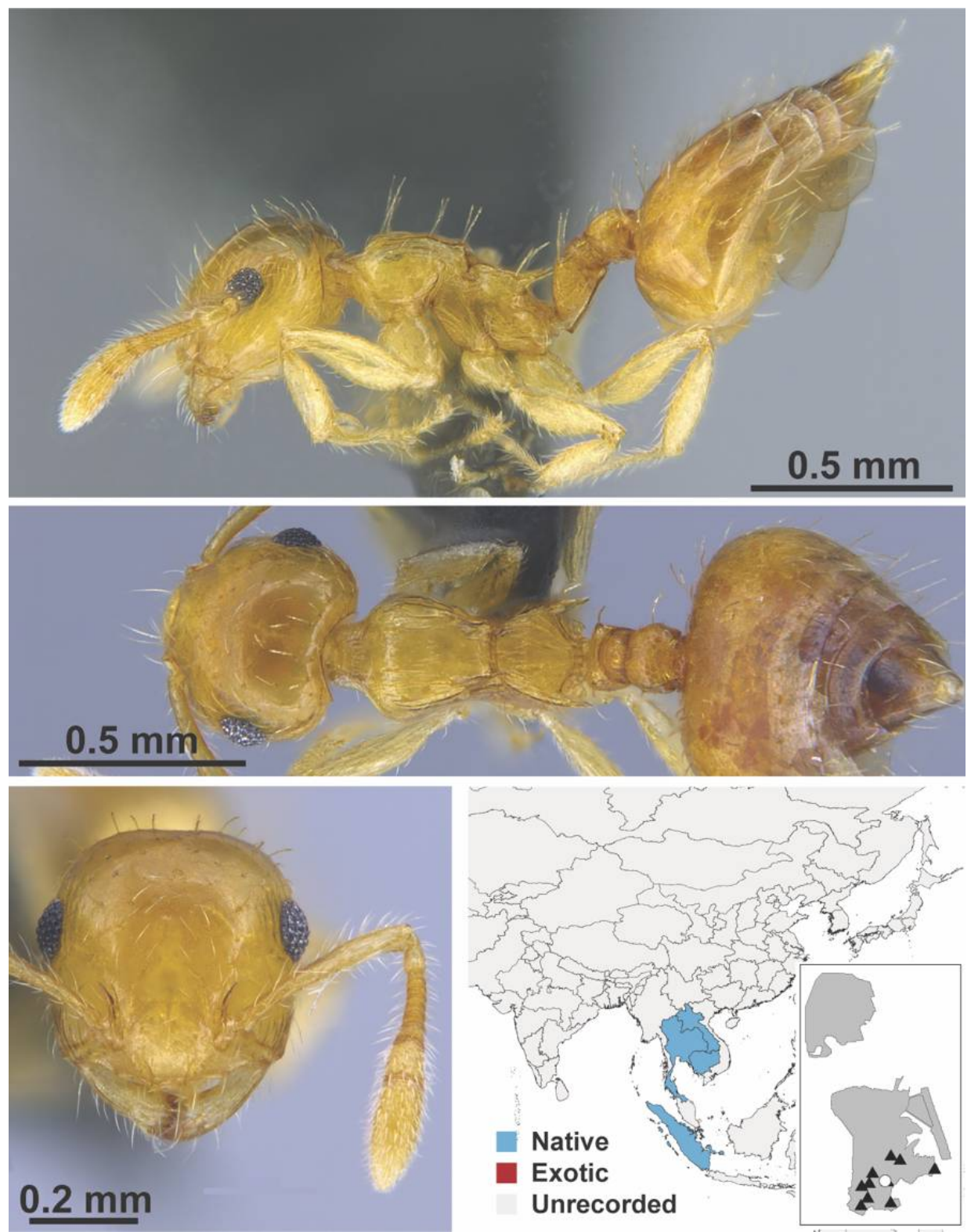

Figure A70. Crematogaster quadriruga Forel, 1911 worker (MAC_S06_LLSA_sp.1, IBBL). 

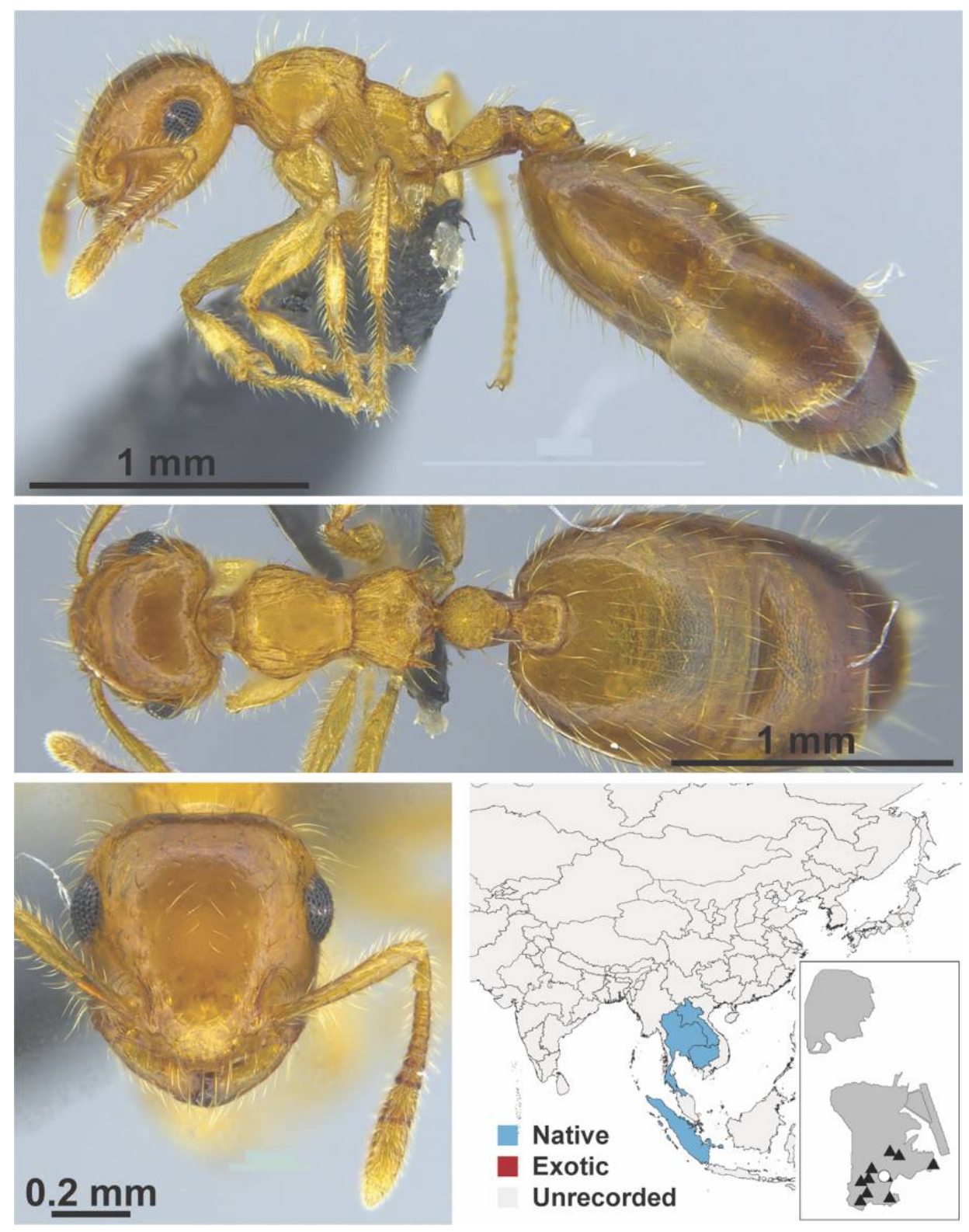

Figure A71. Crematogaster quadriruga Forel, 1911 intercaste (MAC_S17_LLSA_sp.3, IBBL). 

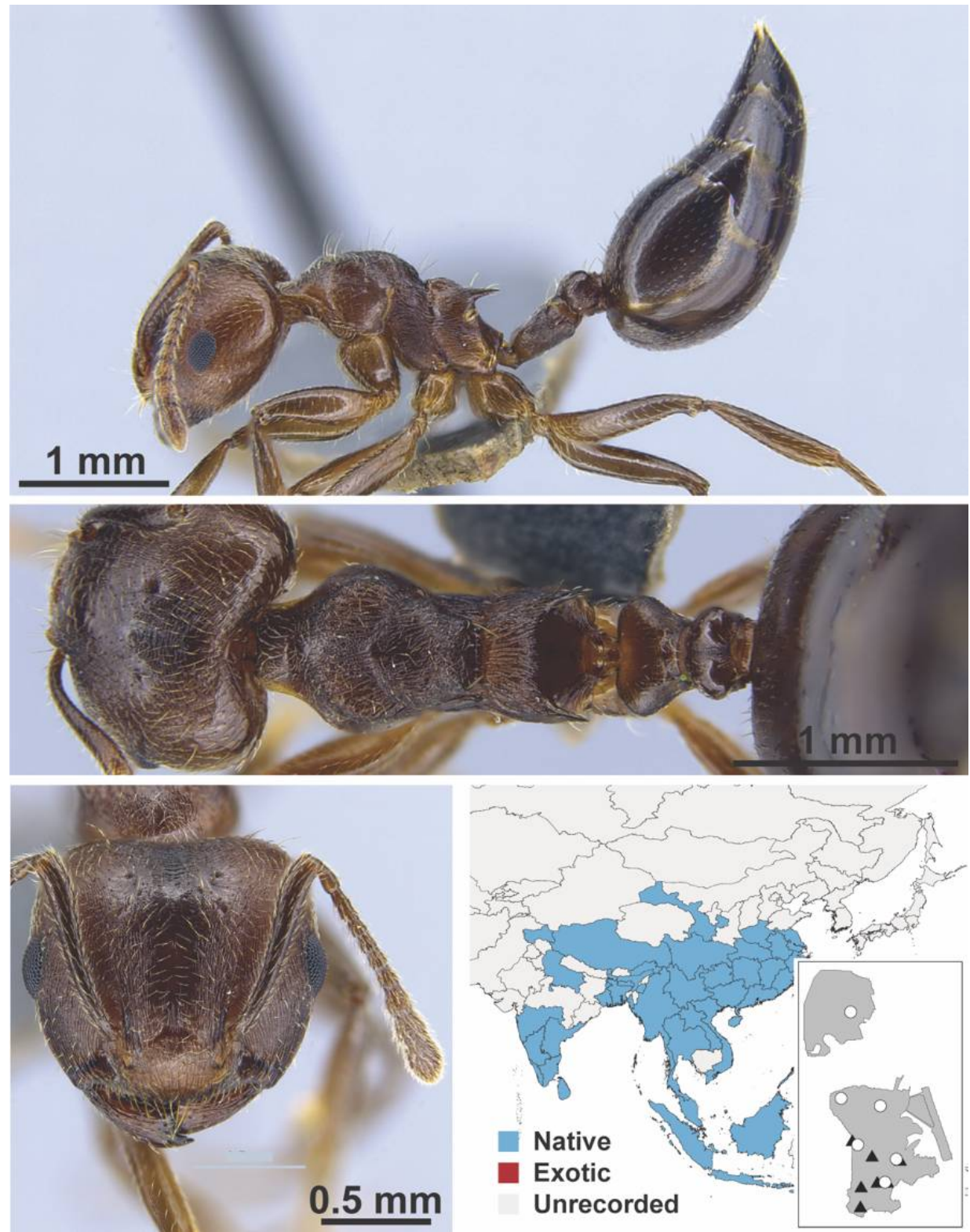

Figure A72. Crematogaster rogenhoferi Mayr, 1879 worker (MAC_S19_T4_1m_sp.1, IBBL). 

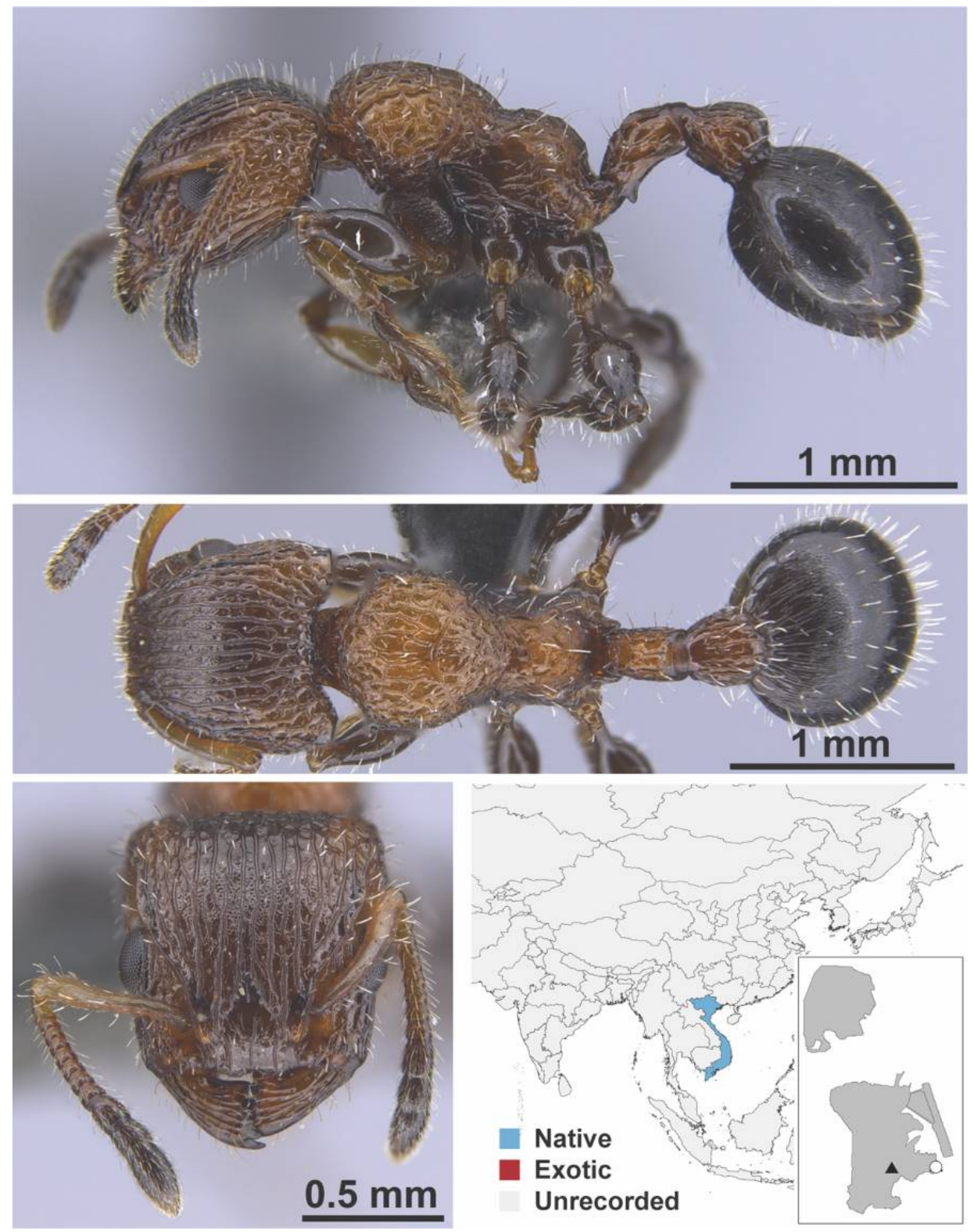

Figure A73. Dilobocondyla propotriangulata, Bharti \& Kumar, 2013 worker (FB19145, IBBL). 

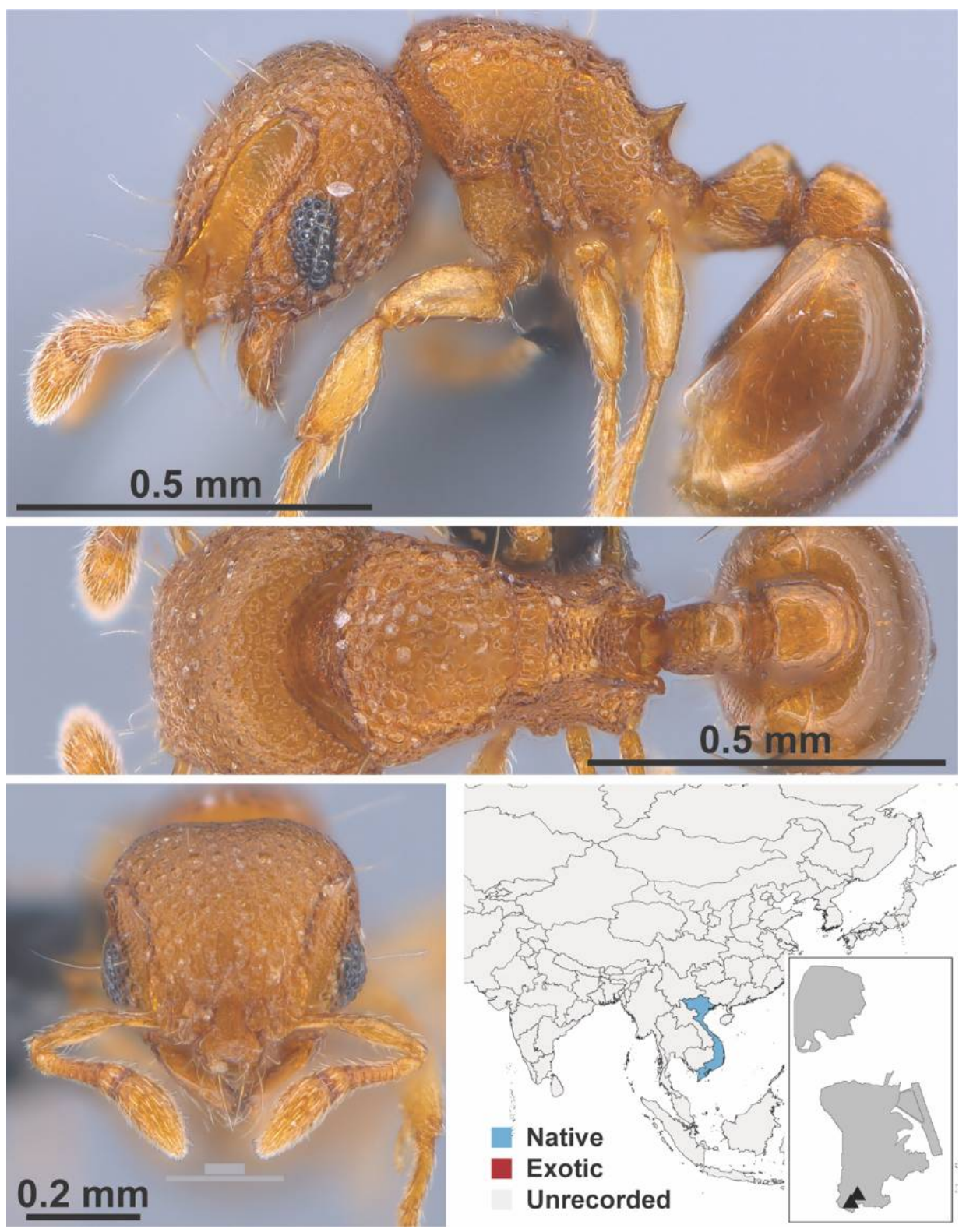

Figure A74. Mayriella granulata, Dlussky \& Radchenko, 1990 worker (MAC_S18_LLSA_Sp.4, IBBL). 


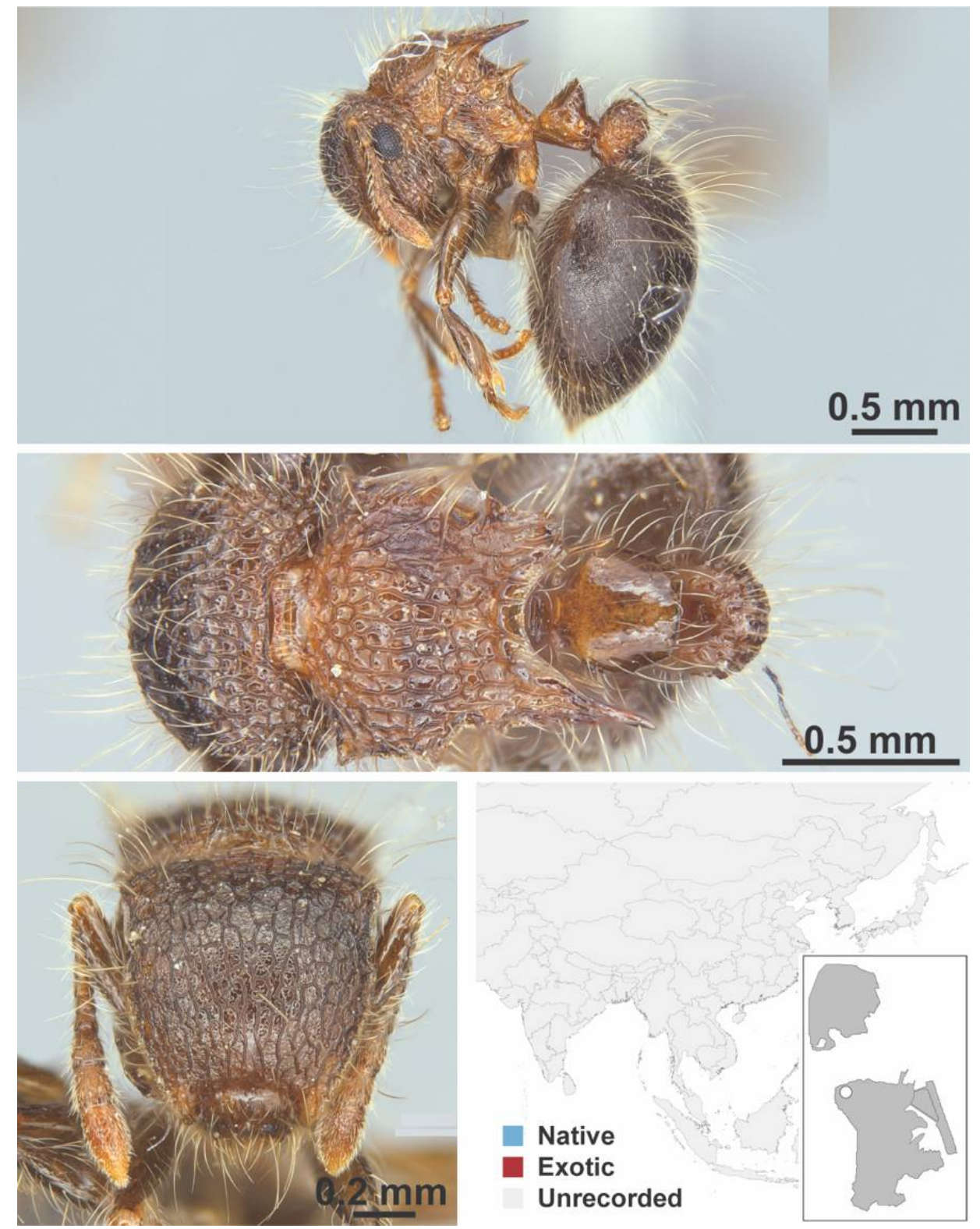

Figure A75. Meranoplus sp. mo01 nr. bicolor Guérin-Méneville, 1844 worker (Meranoplus sp. mo01 nr. Bicolor, CML collection). 

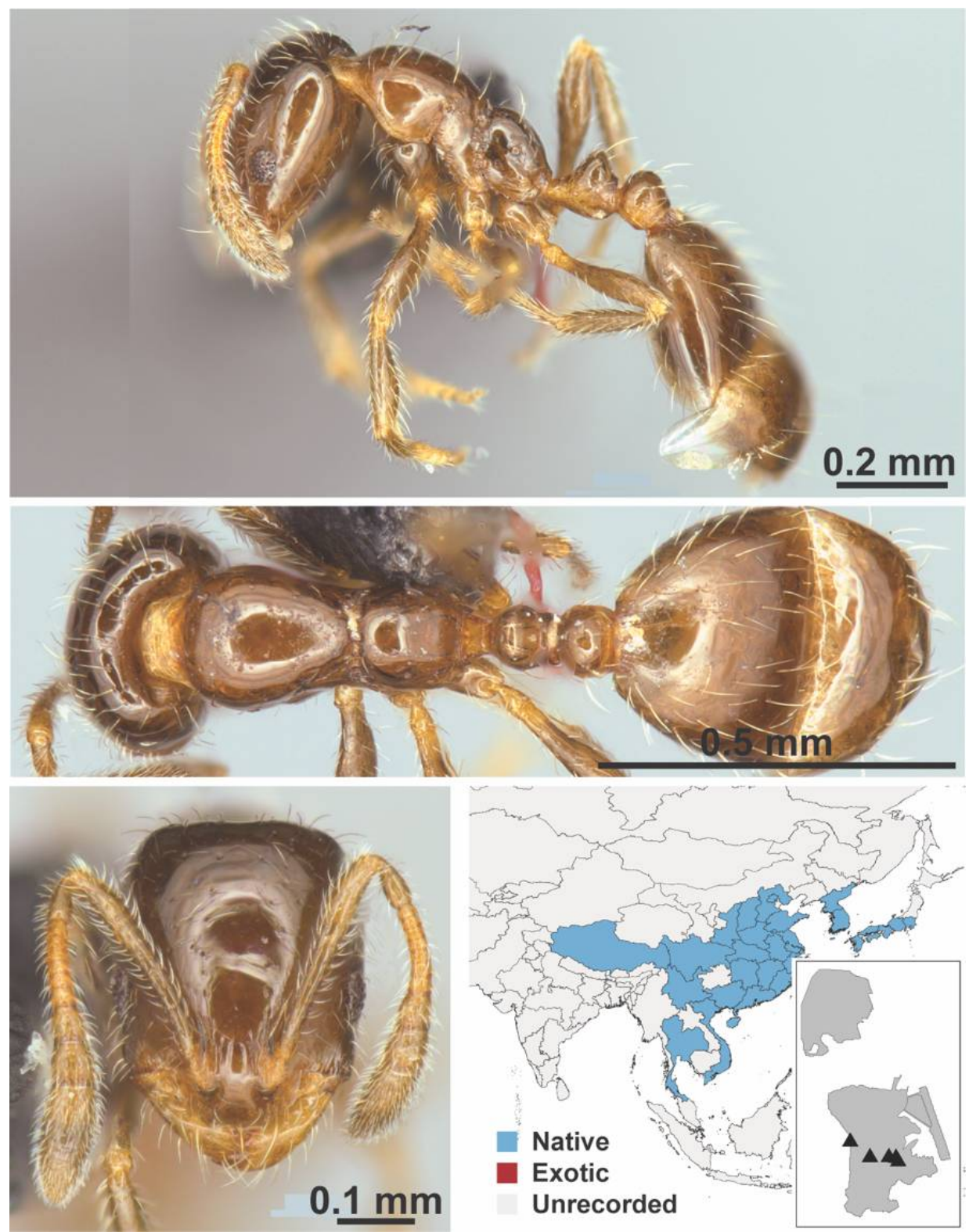

Figure A76. Monomorium chinense Santschi, 1925 worker (MAC_S20_LLSP_sp.12, IBBL). 

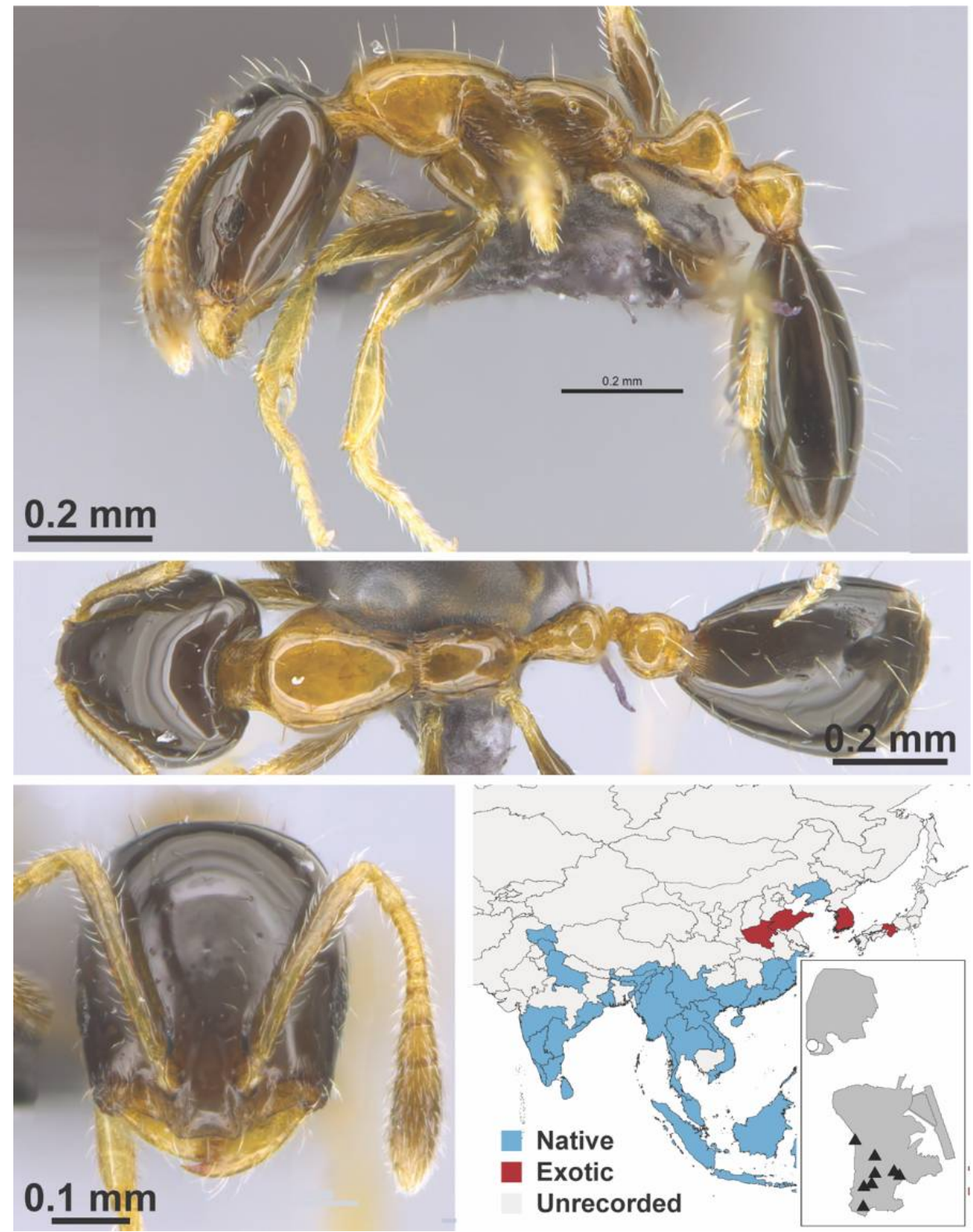

Figure A77. Monomorium floricola Jerdon, 1851 worker (MAC_S03_LLSA_Sp.8, IBBL). 

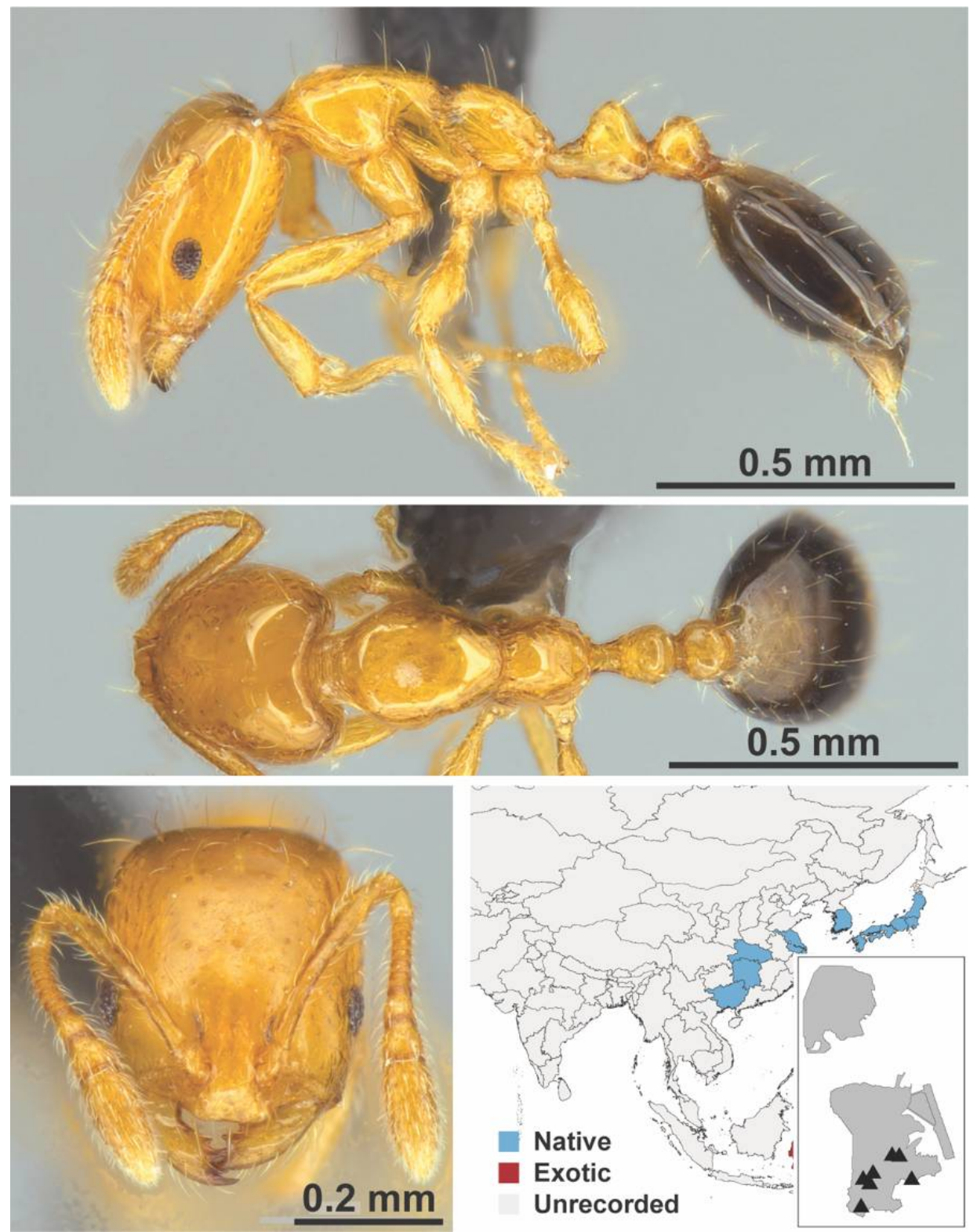

Figure A78. Monomorium intrudens Smith, 1874 worker (MAC_S18_LLSP_sp.3, IBBL). 

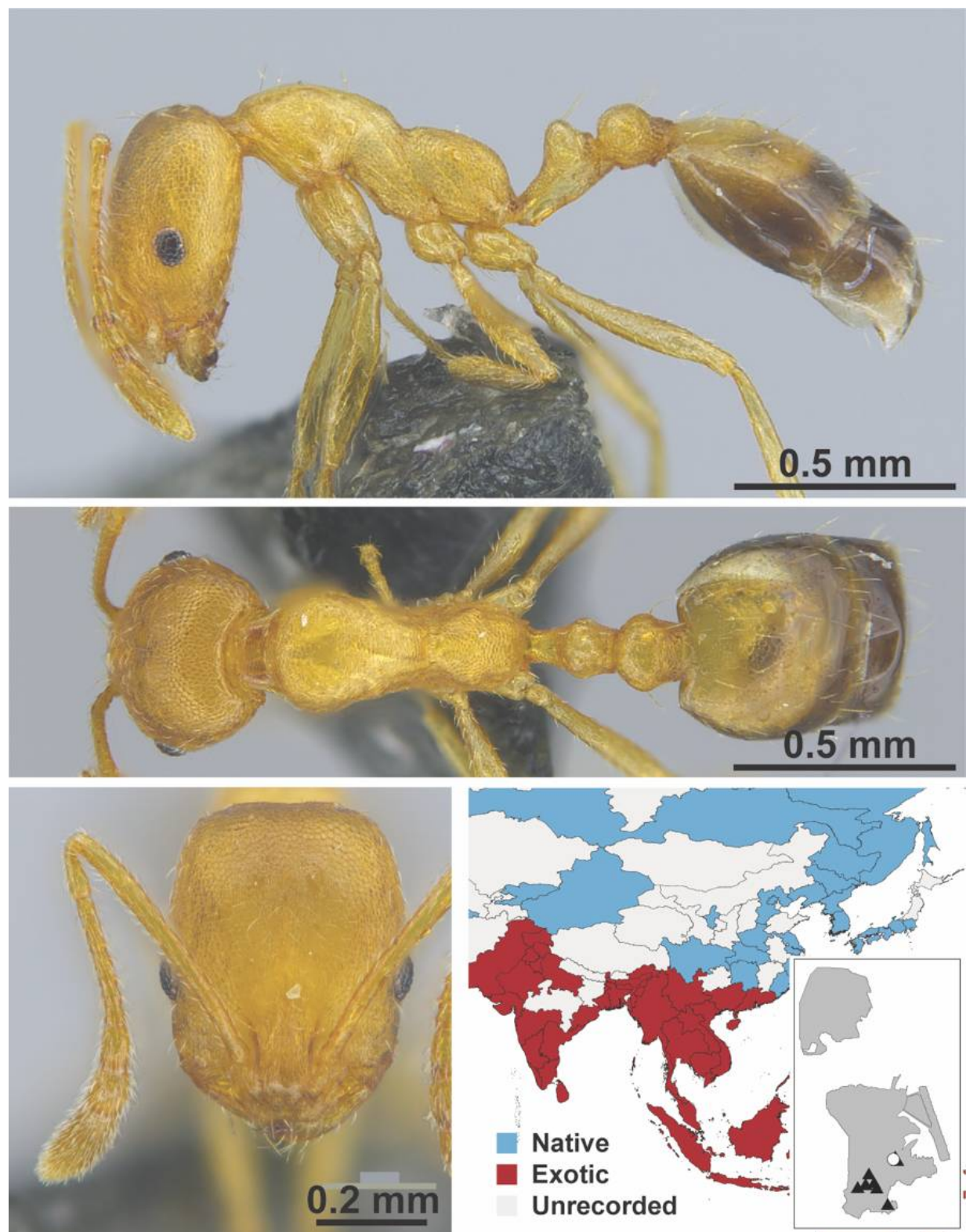

Figure A79. Monomorium pharaonis Linnaeus, 1758 worker (MAC_S09_LLSA_sp.9, IBBL). 

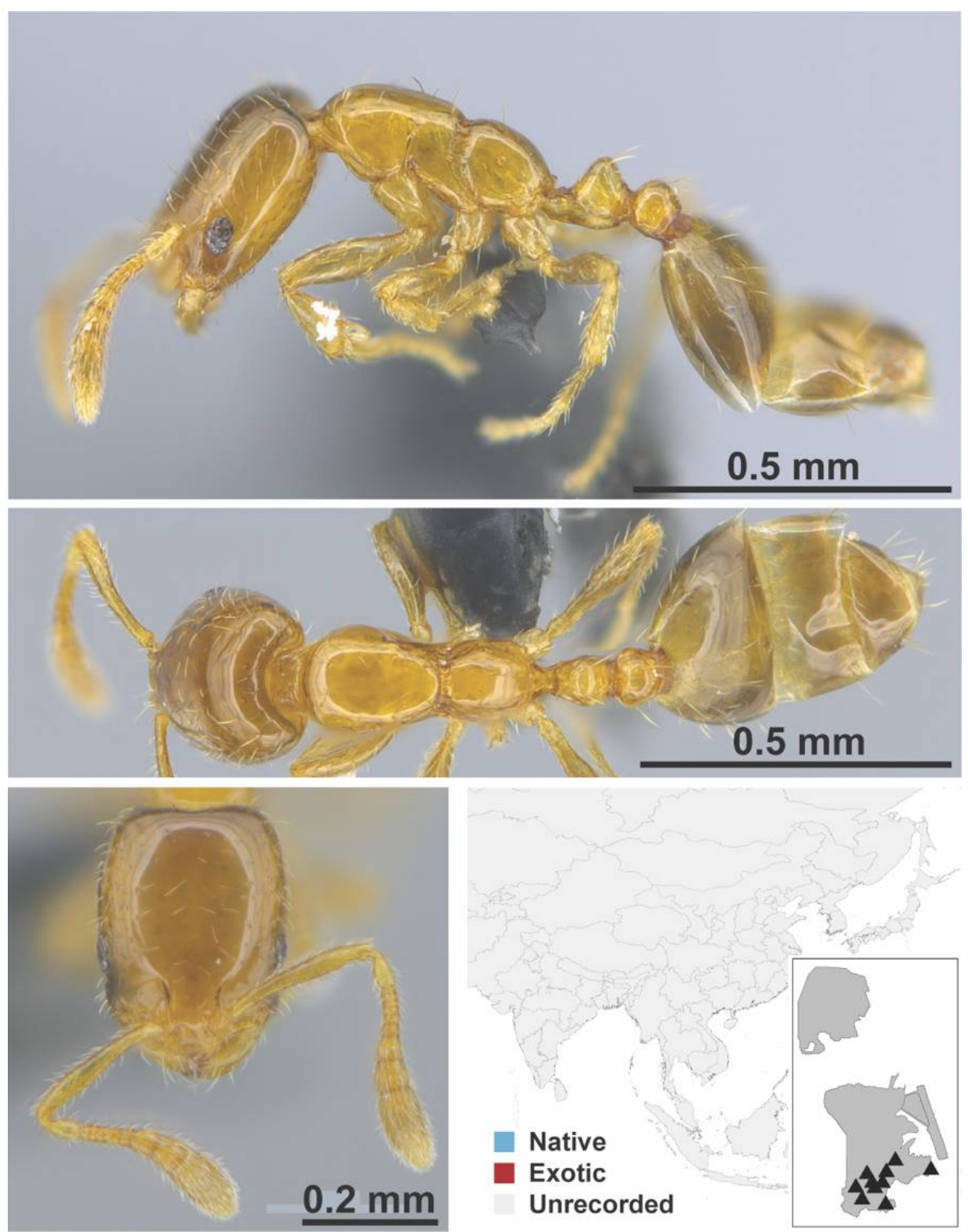

Figure A80. Monomorium sp. psw-cn01 worker (MAC_S21_LLSA_bottom_sp.2, IBBL). 


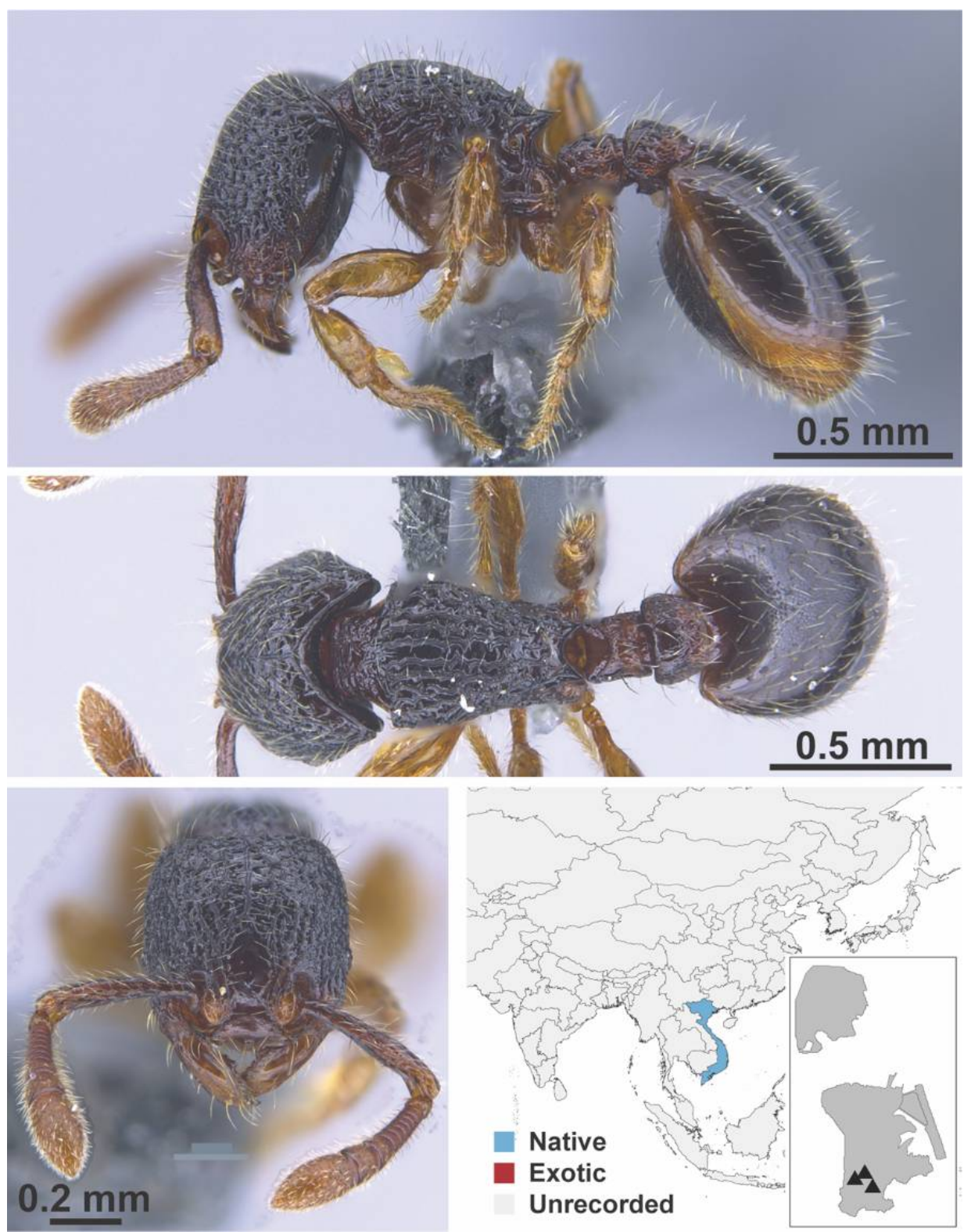

Figure A81. Myrmecina nomurai Okido, Ogata \& Hosoishi, 2020 worker (MAC_S05_LLSA_ Sp.1, IBBL). 


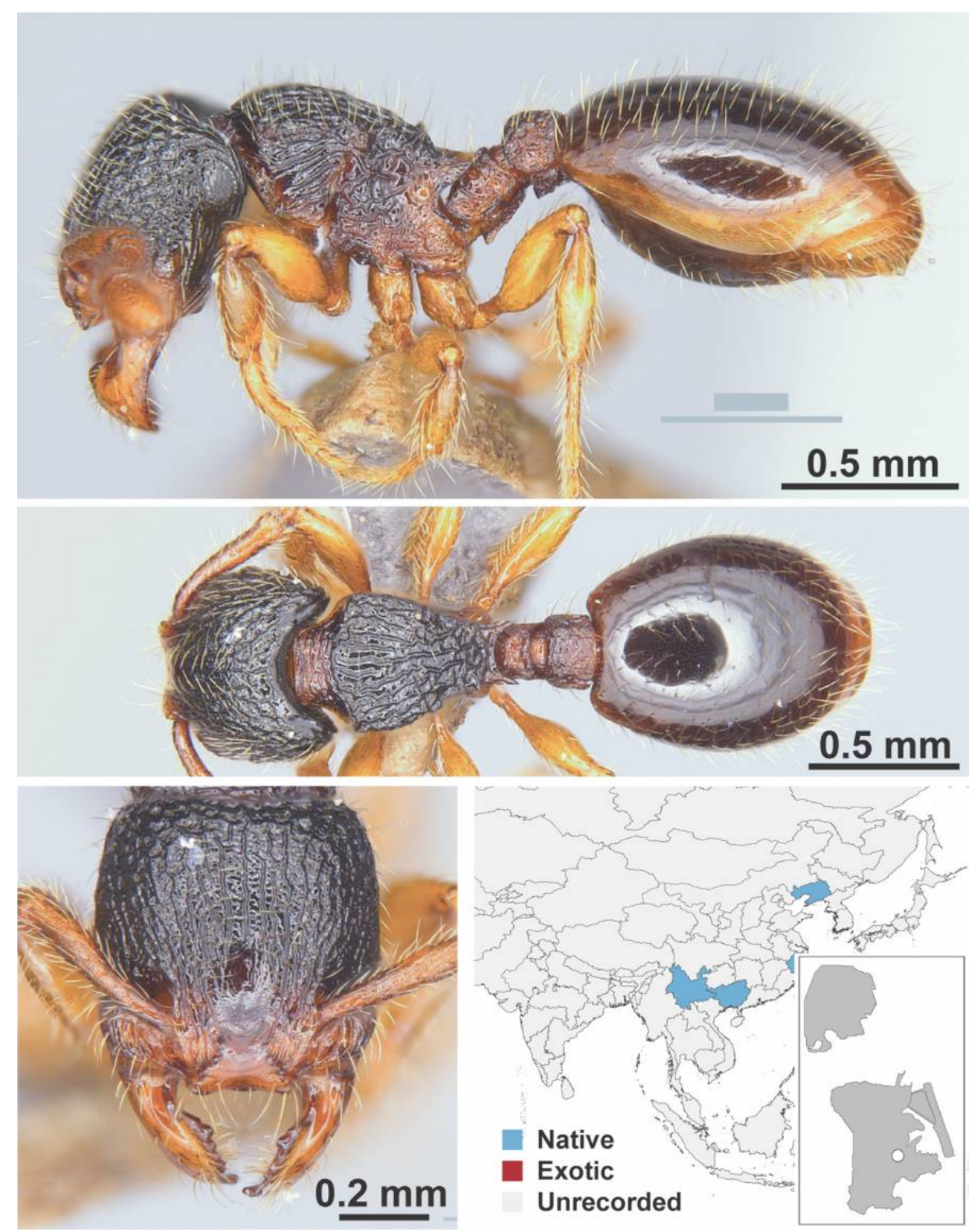

Figure A82. Myrmecina sinensis Wheeler, W. M., 1921 worker (Myrmecina sinensis, CML collection). 

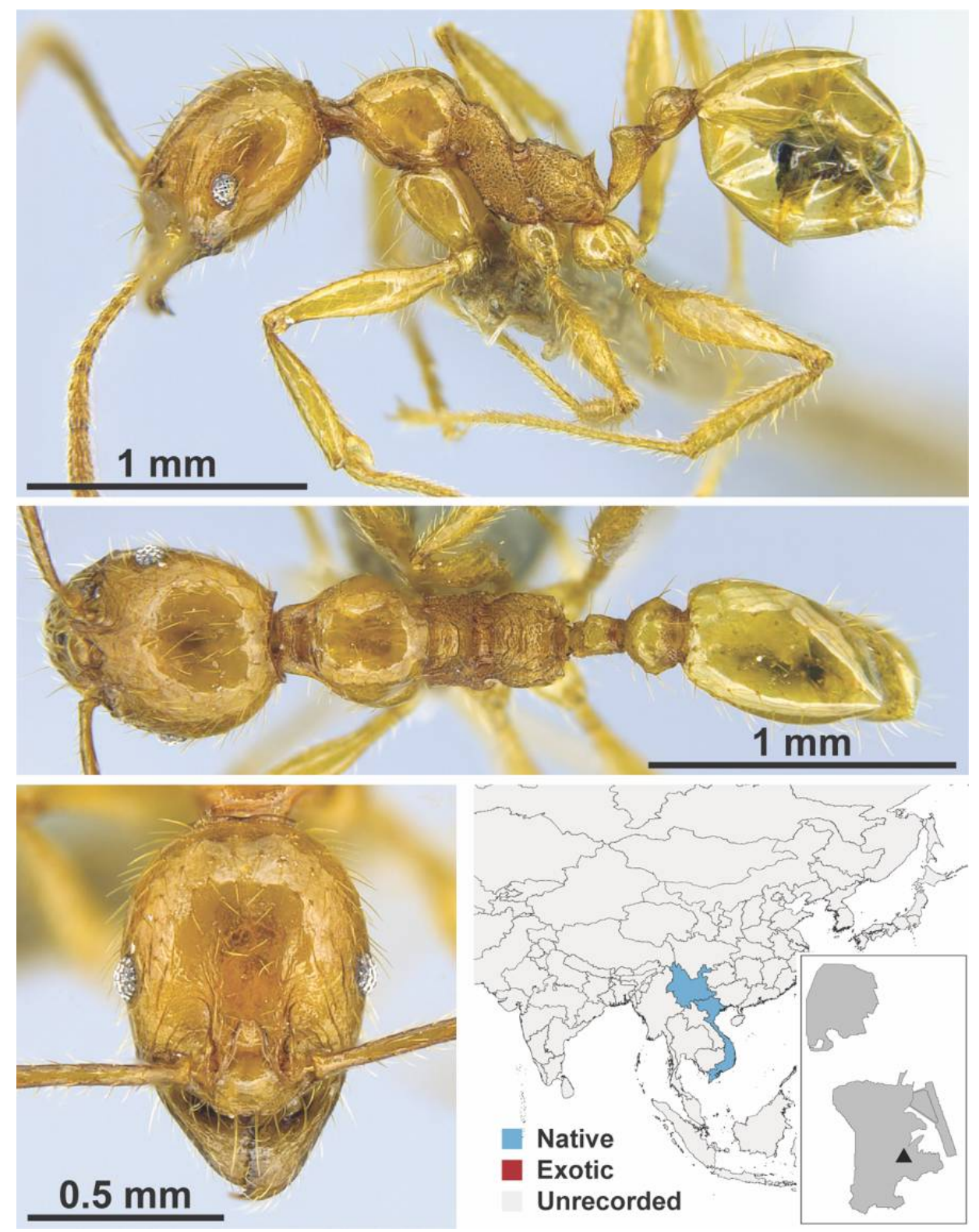

Figure A83. Pheidole elongicephala Eguchi, 2008 worker (MAC_S09_q2_25_sp.2, IBBL). 

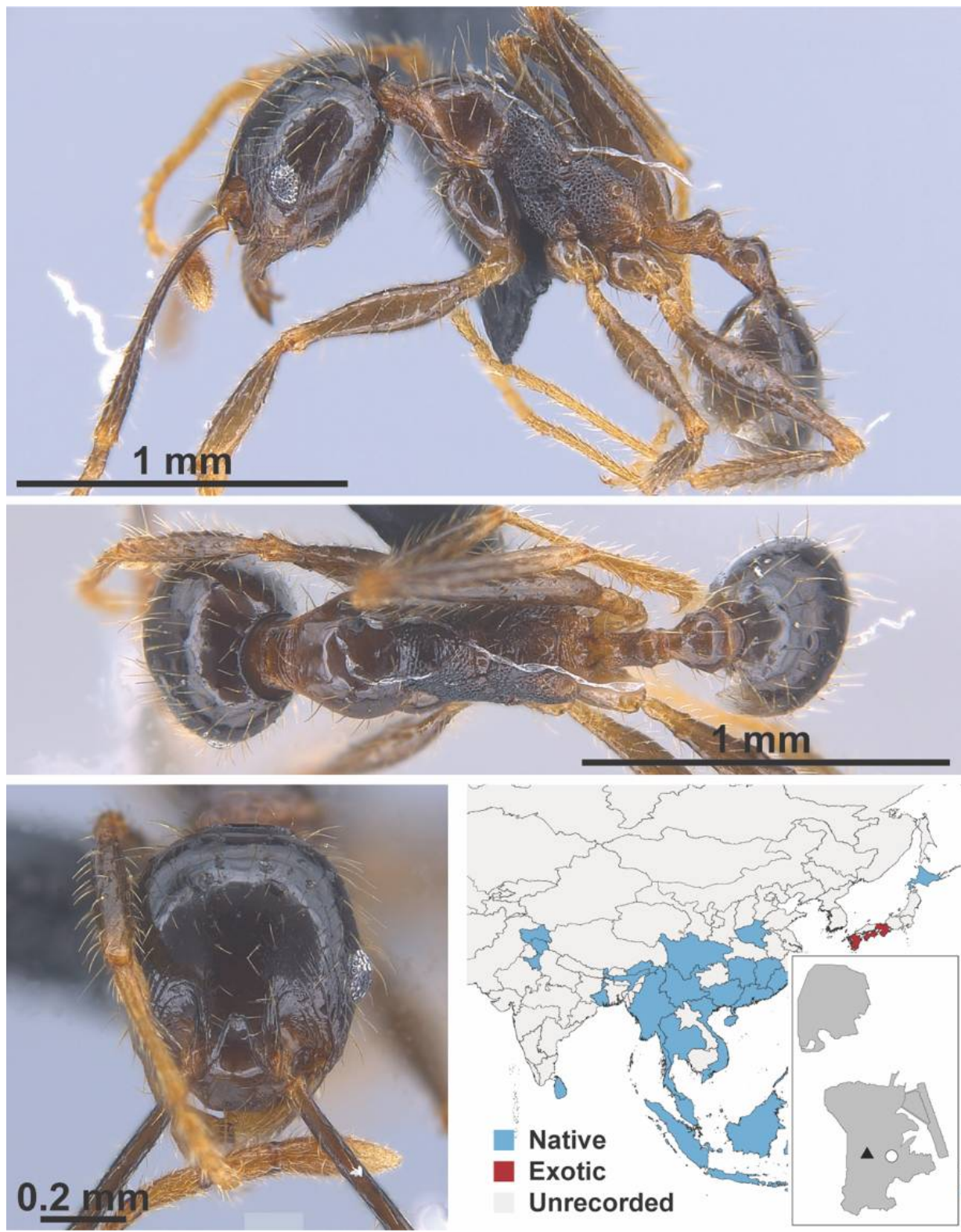

Figure A84. Pheidole fervens Smith, 1858 worker (MAC_S19_q4_GL_03_Sp.2, IBBL). 

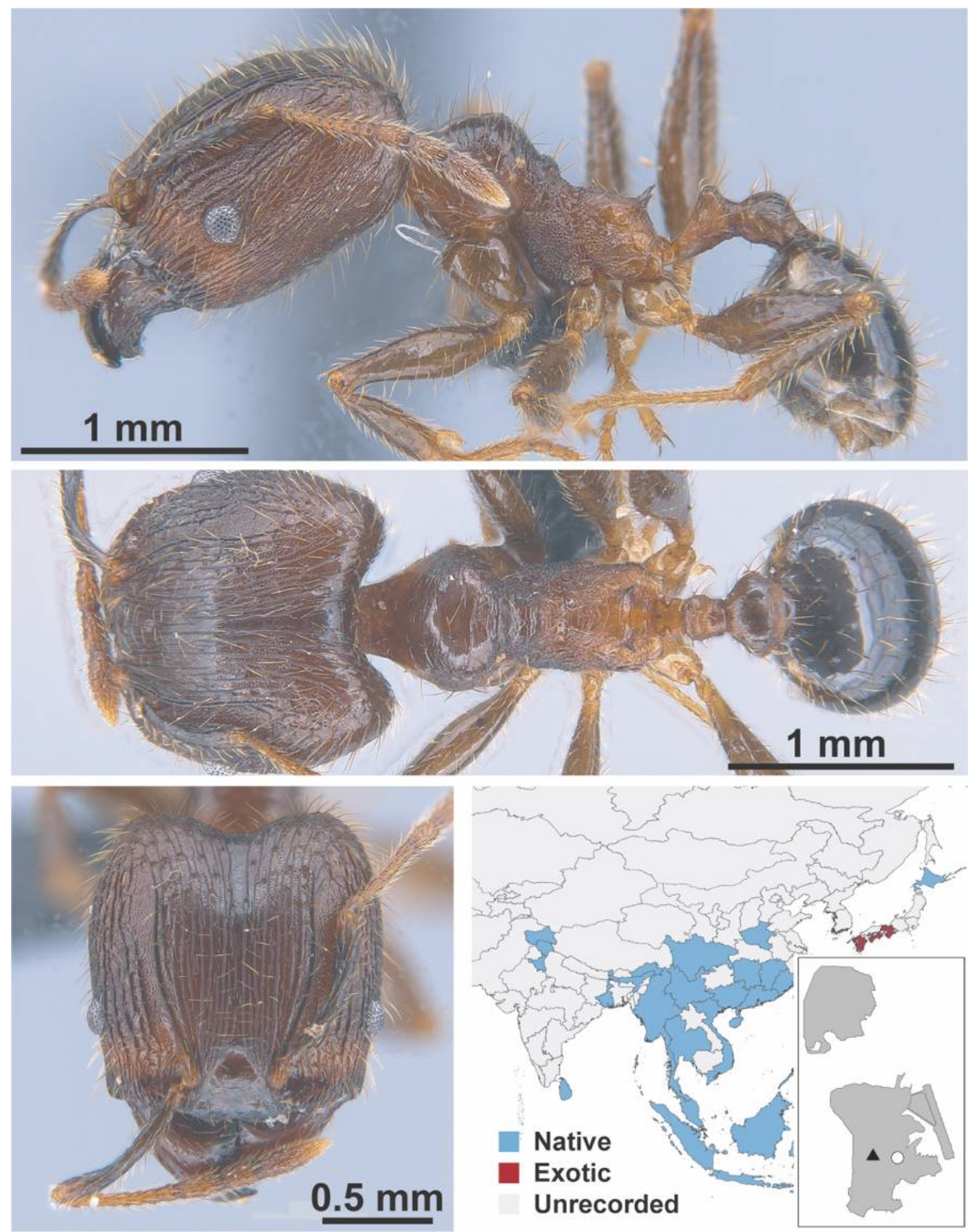

Figure A85. Pheidole fervens Smith, 1858 major (MAC_S19_q4_GL_03_Sp.2, IBBL). 

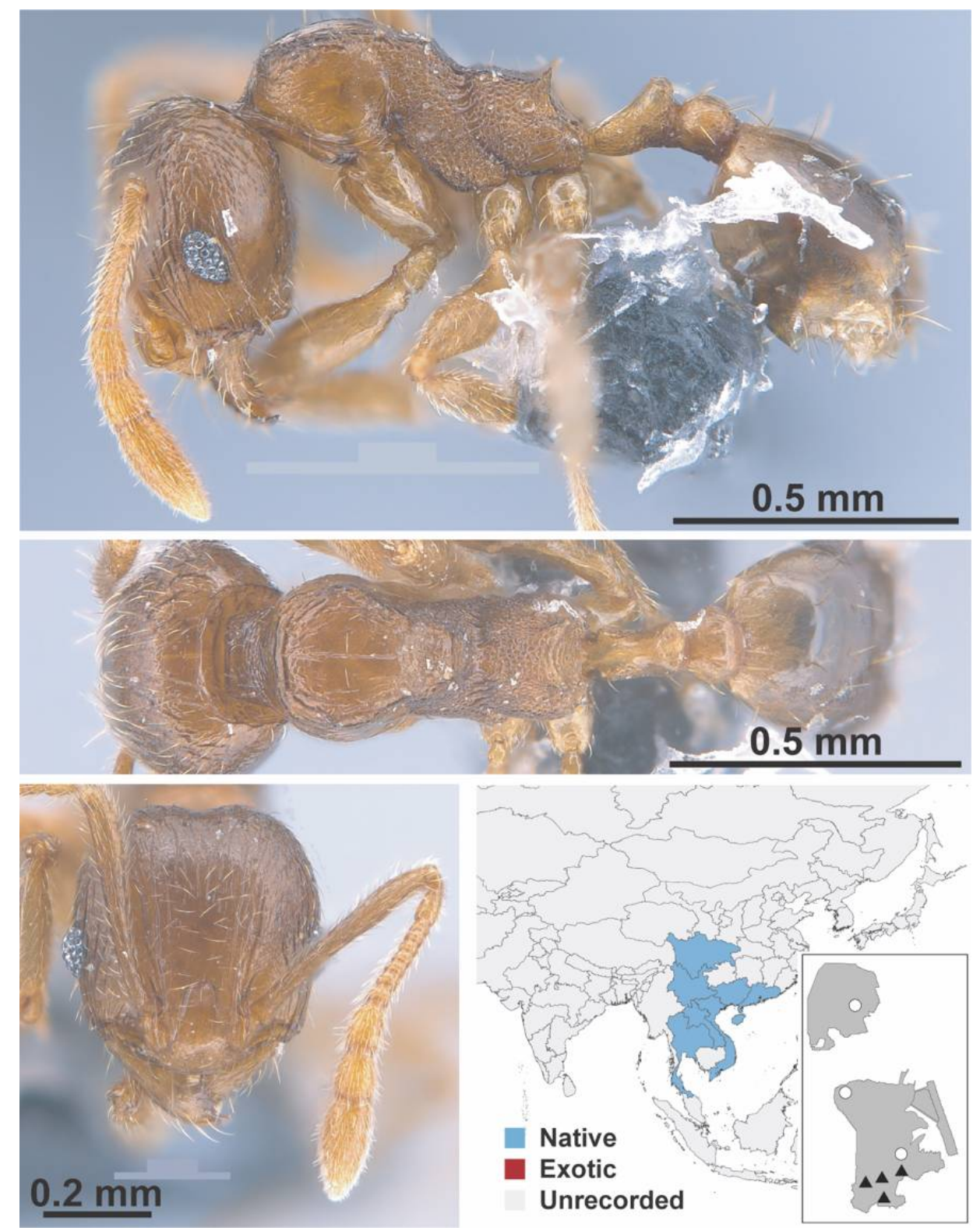

Figure A86. Pheidole hongkongensis Wheeler, 1928 worker (MAC_S21_LLSP_Sp.9, IBBL). 

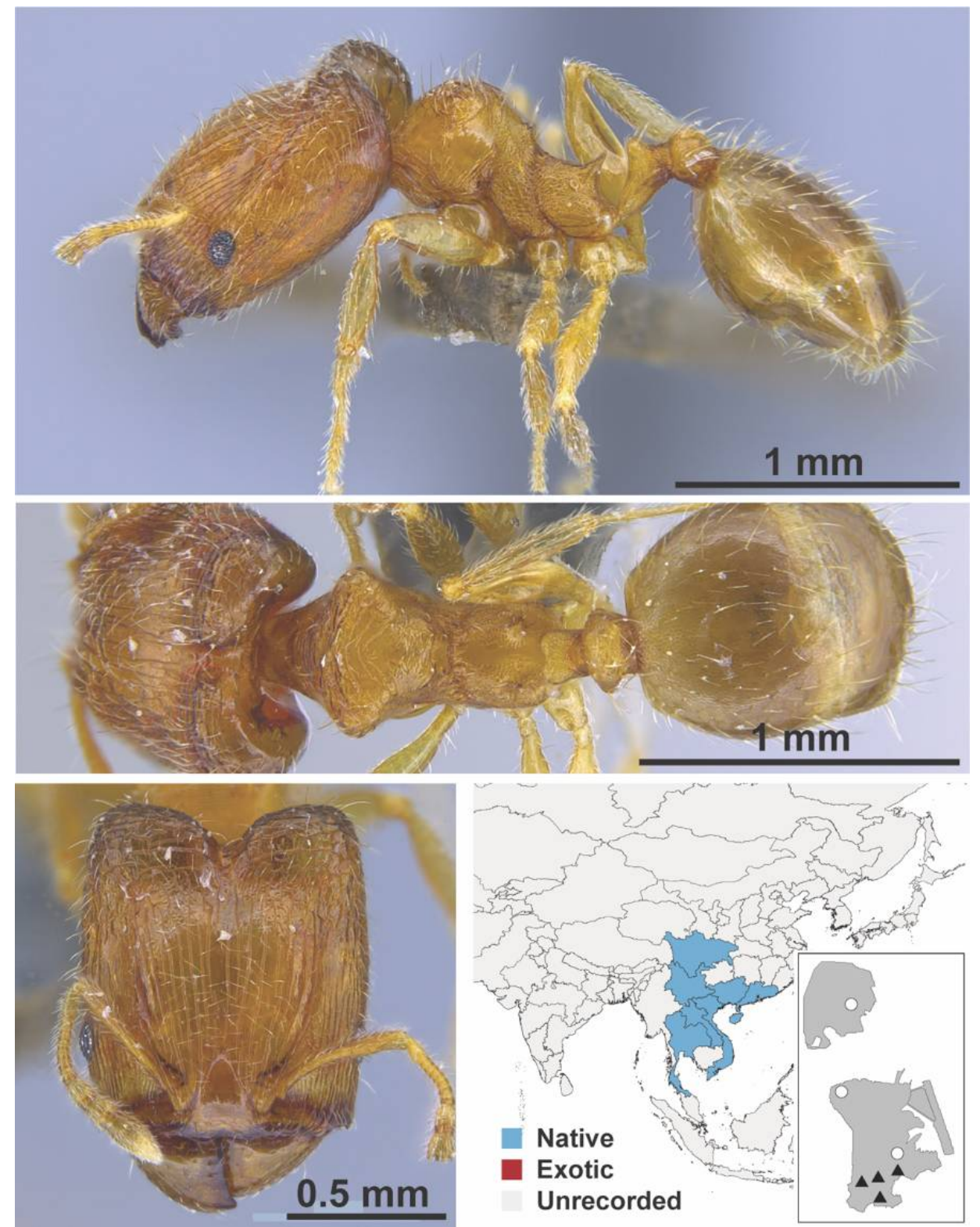

Figure A87. Pheidole hongkongensis Wheeler, 1928 major (MAC_S07_B08_sp.1, IBBL). 

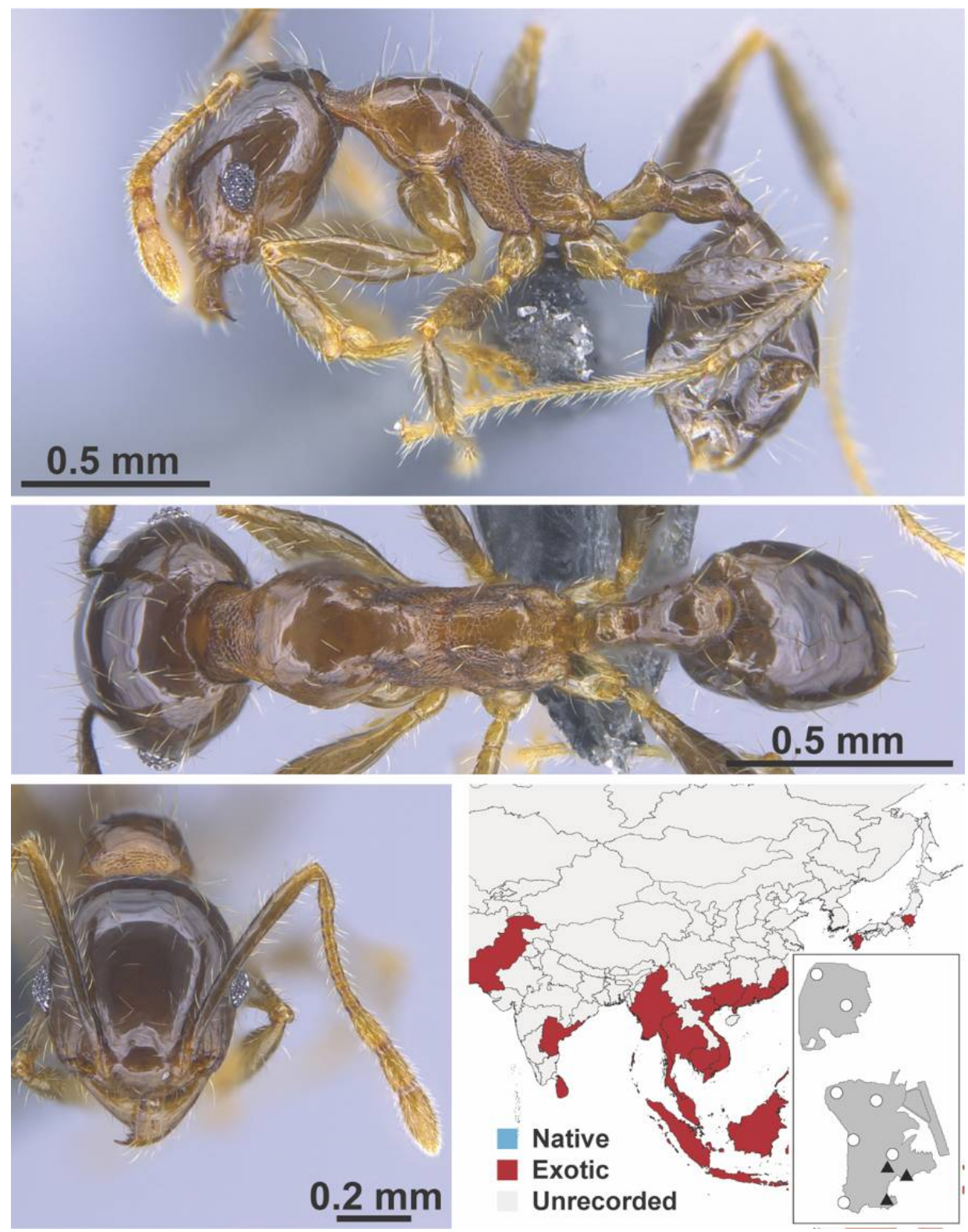

Figure A88. Pheidole megacephala Fabricius, 1793 worker (MAC_S13_LLSP_Sp.1, IBBL). 

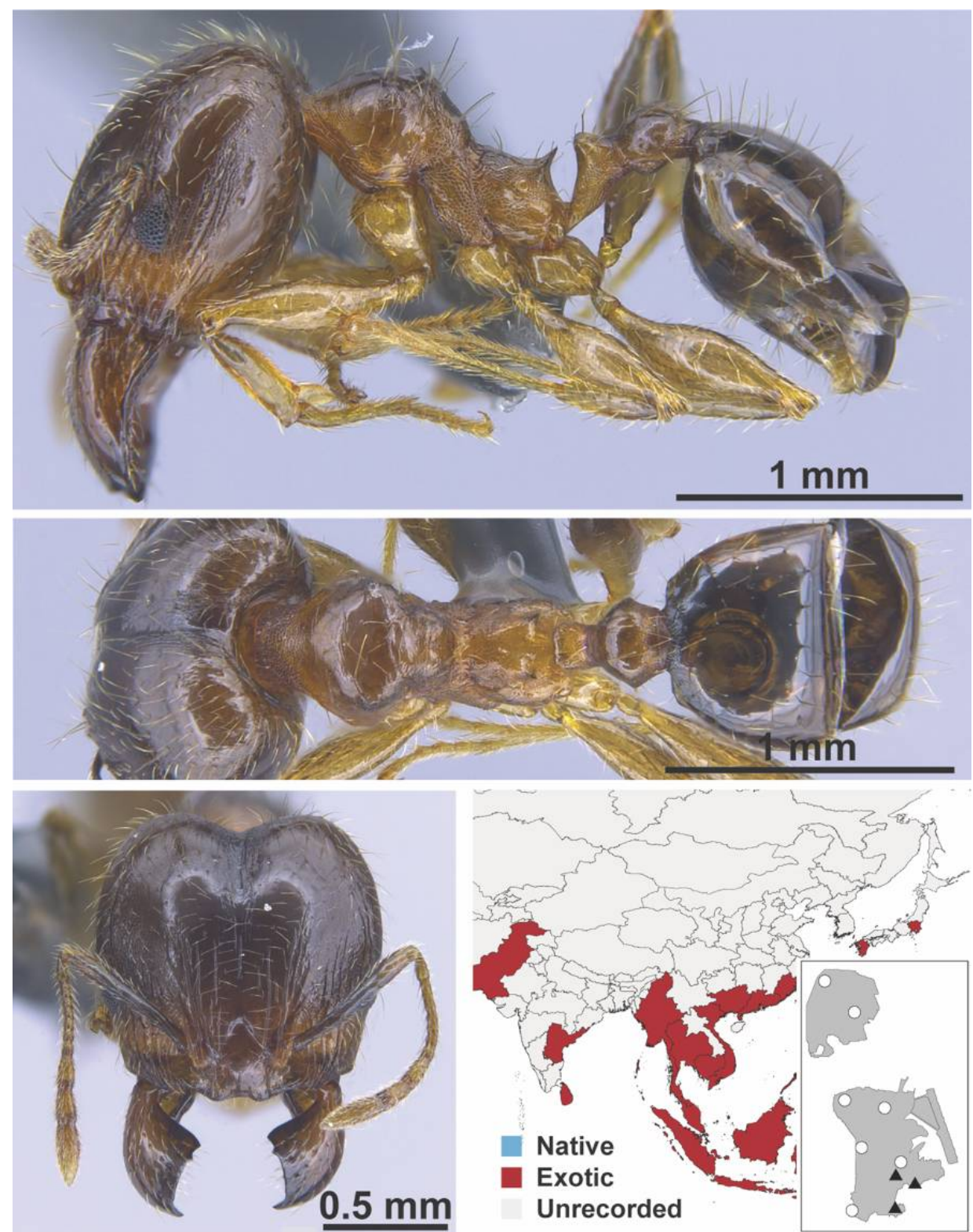

Figure A89. Pheidole megacephala Fabricius, 1793 major (MAC_S13_LLSP_Sp.1, IBBL). 


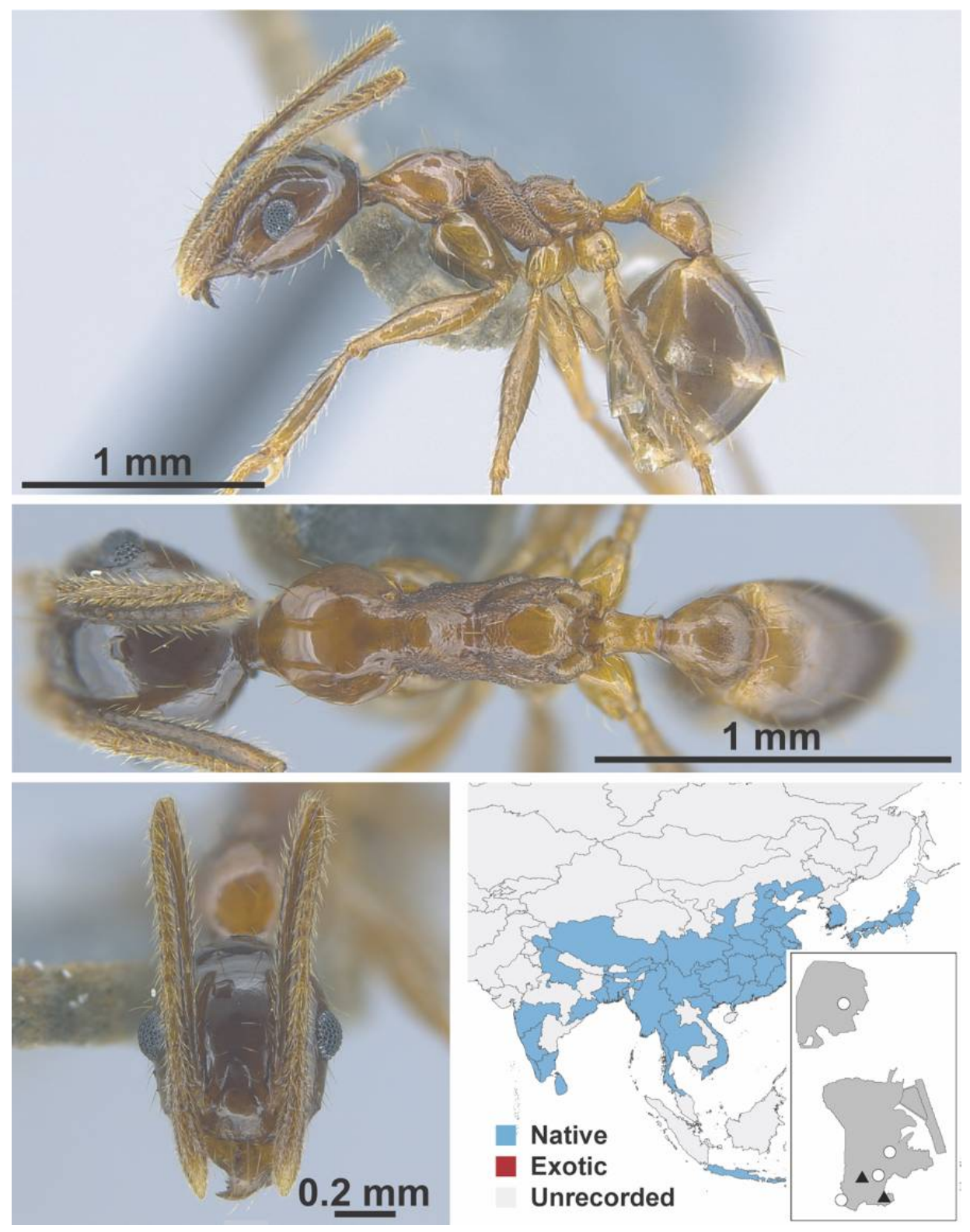

Figure A90. Pheidole nodus Smith, 1874 worker (MAC_S02_B09_sp.1_top, IBBL). 


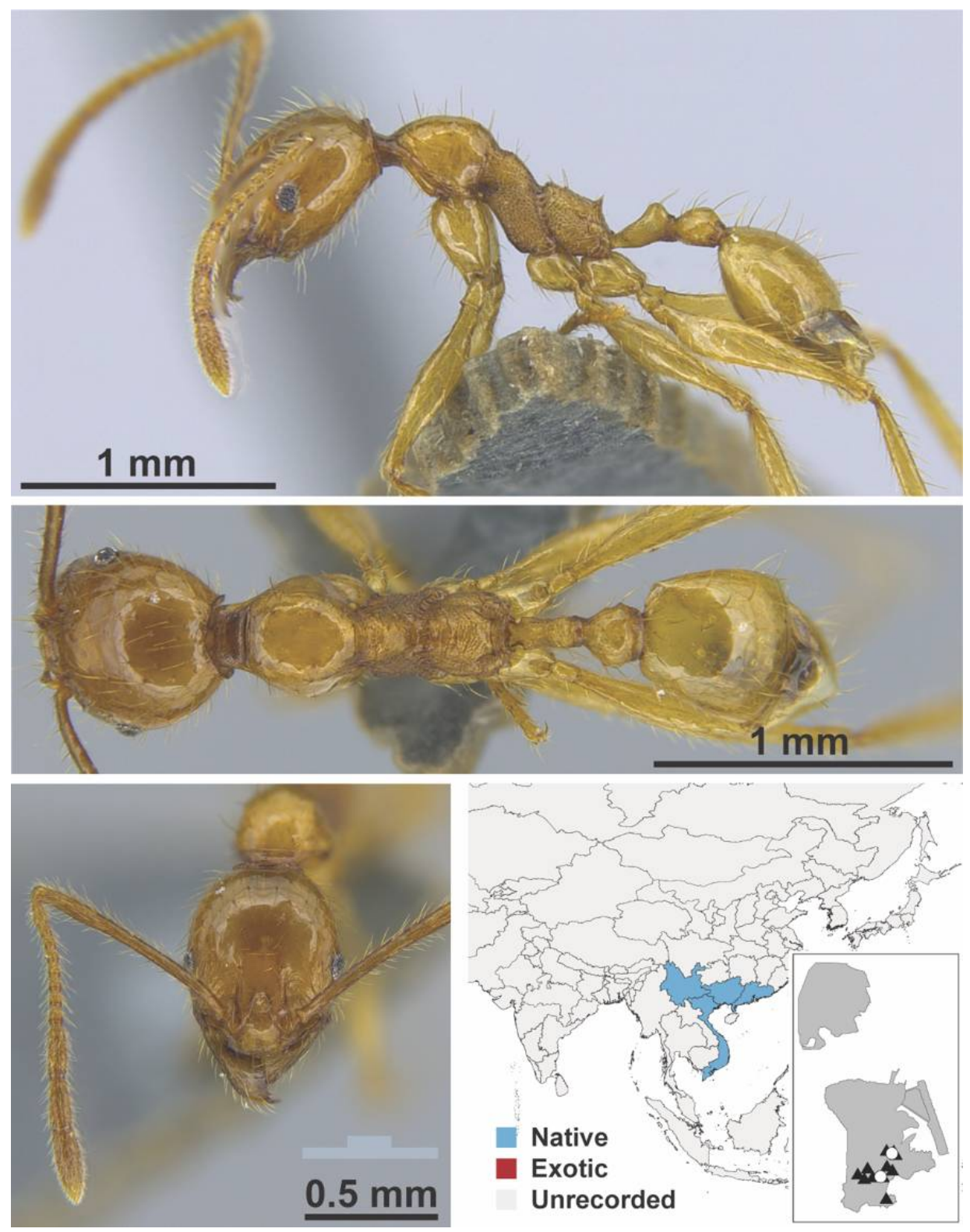

Figure A91. Pheidole ochracea Eguchi, 2008 worker (MAC_S03_B03_sp.1, IBBL). 


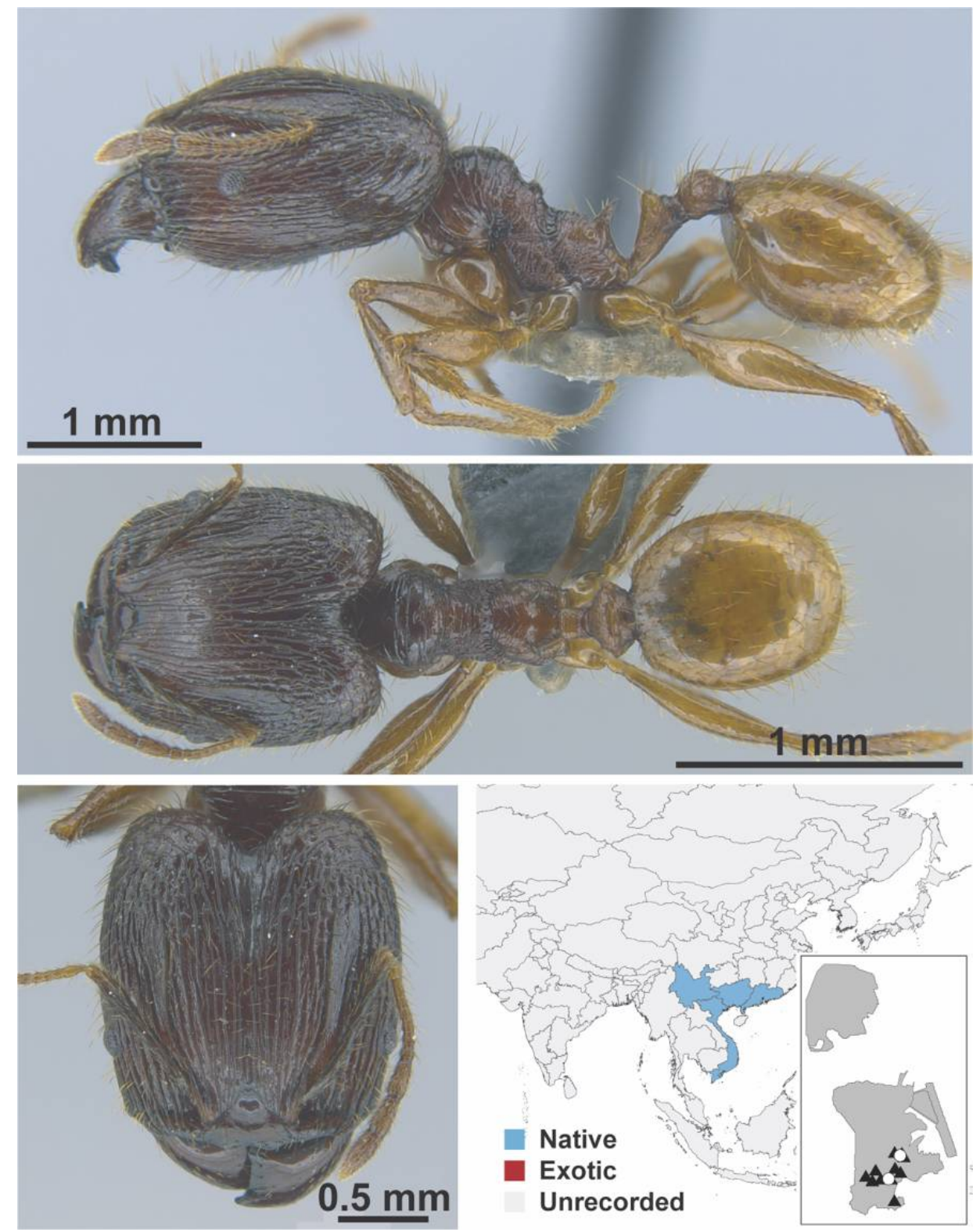

Figure A92. Pheidole ochracea Eguchi, 2008 major (MAC_S03_B03_sp.1, IBBL). 


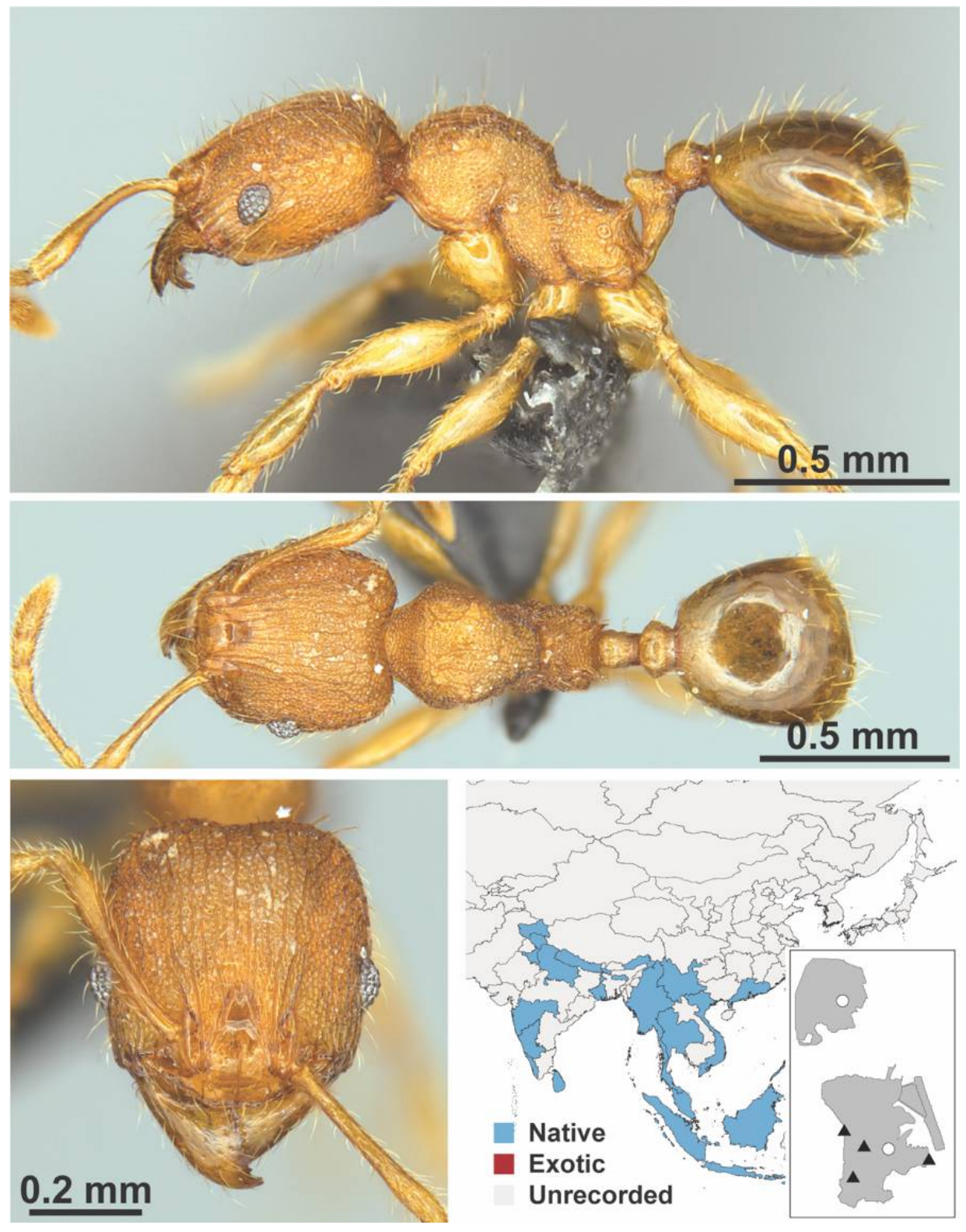

Figure A93. Pheidole parva Mayr, 1865 worker (MAC_S20_LLSA_sp.4, IBBL). 

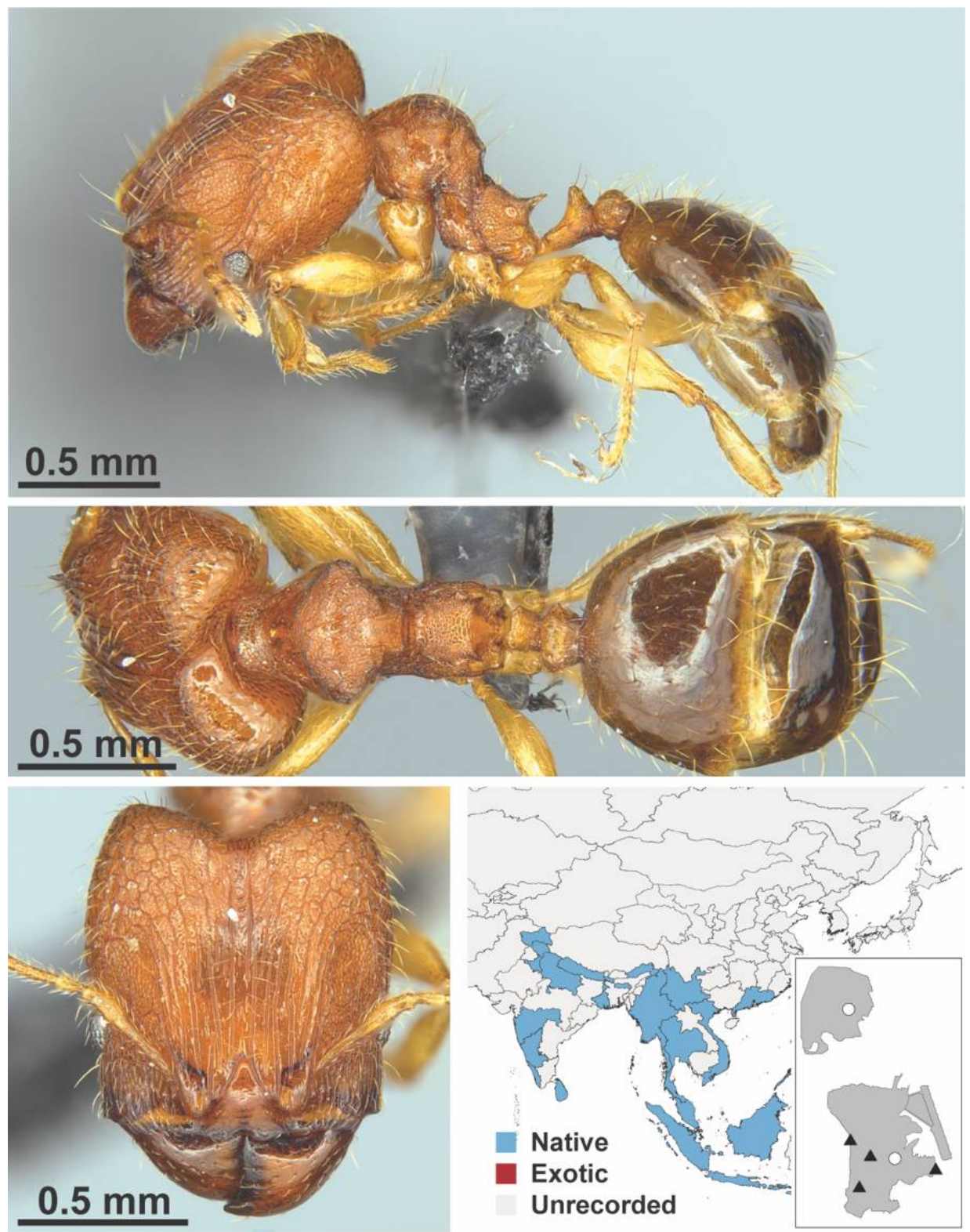

Figure A94. Pheidole parva Mayr, 1865 major (MAC_S20_LLSA_sp.4, IBBL). 

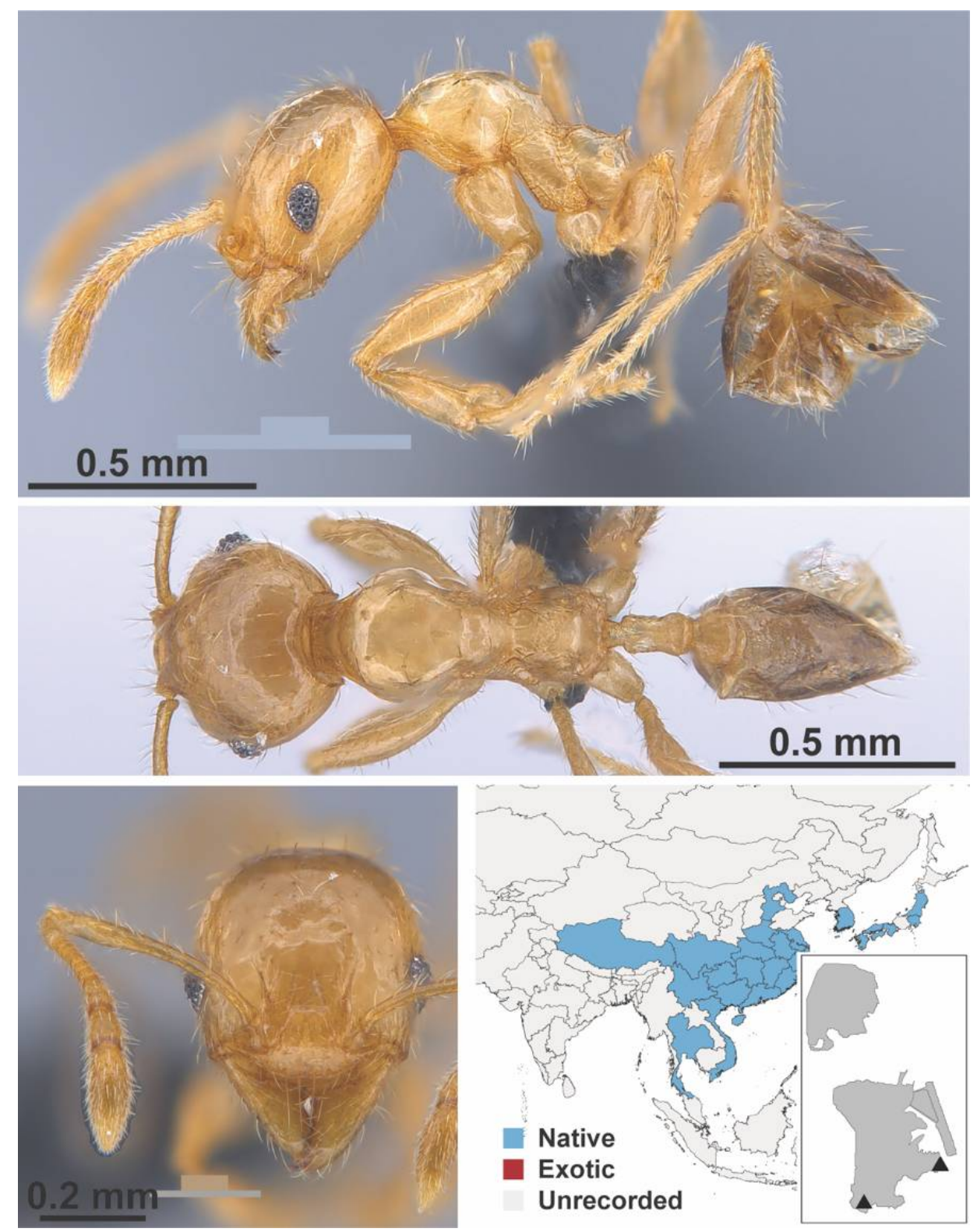

Figure A95. Pheidole pieli Santschi, 1925 worker (MAC_S17_LLSA_Sp.4, IBBL). 

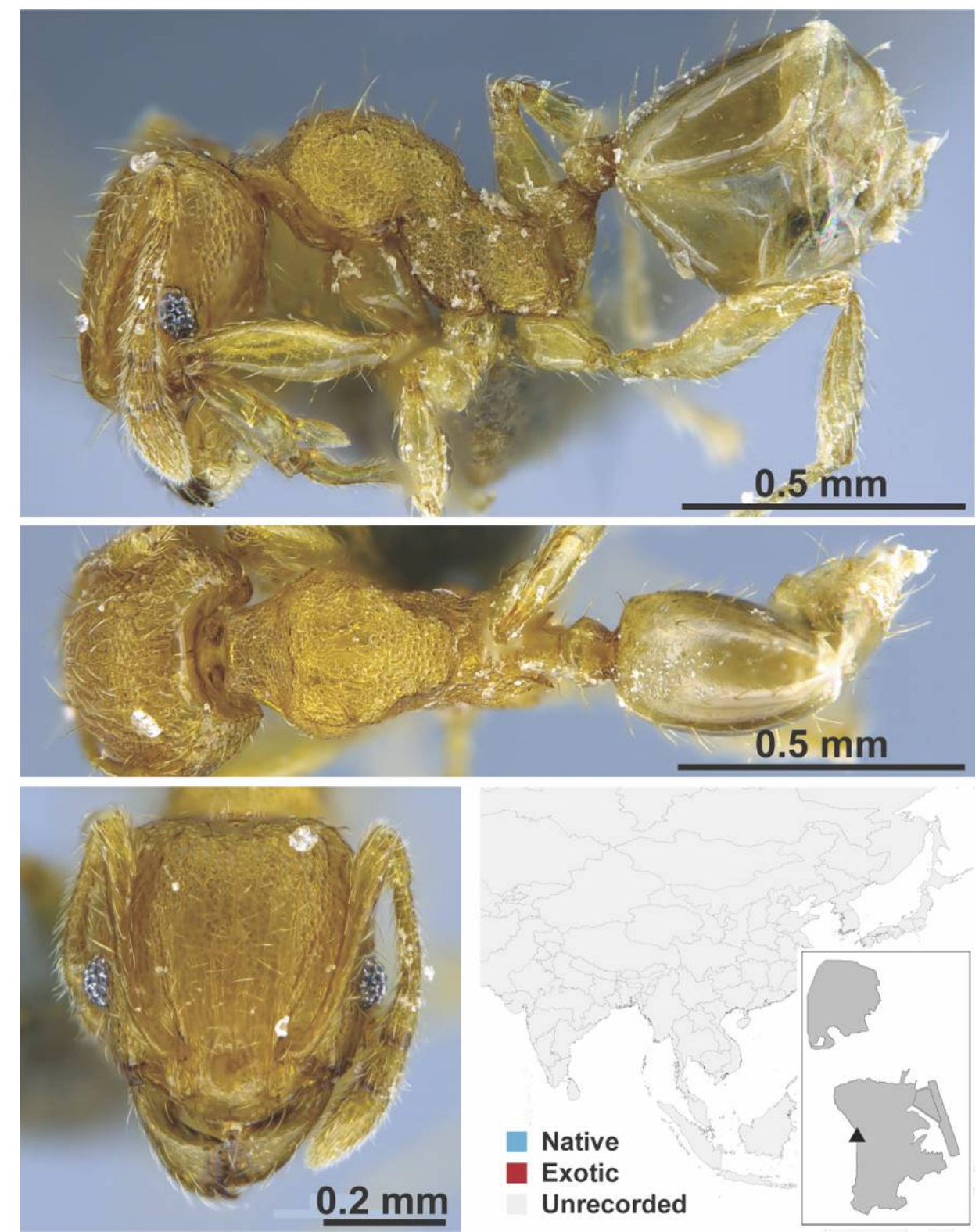

Figure A96. Pheidole nr. ryukyuensis Ogata, 1982 worker (MAC_S20_12.5_q4_sp.2, IBBL). 

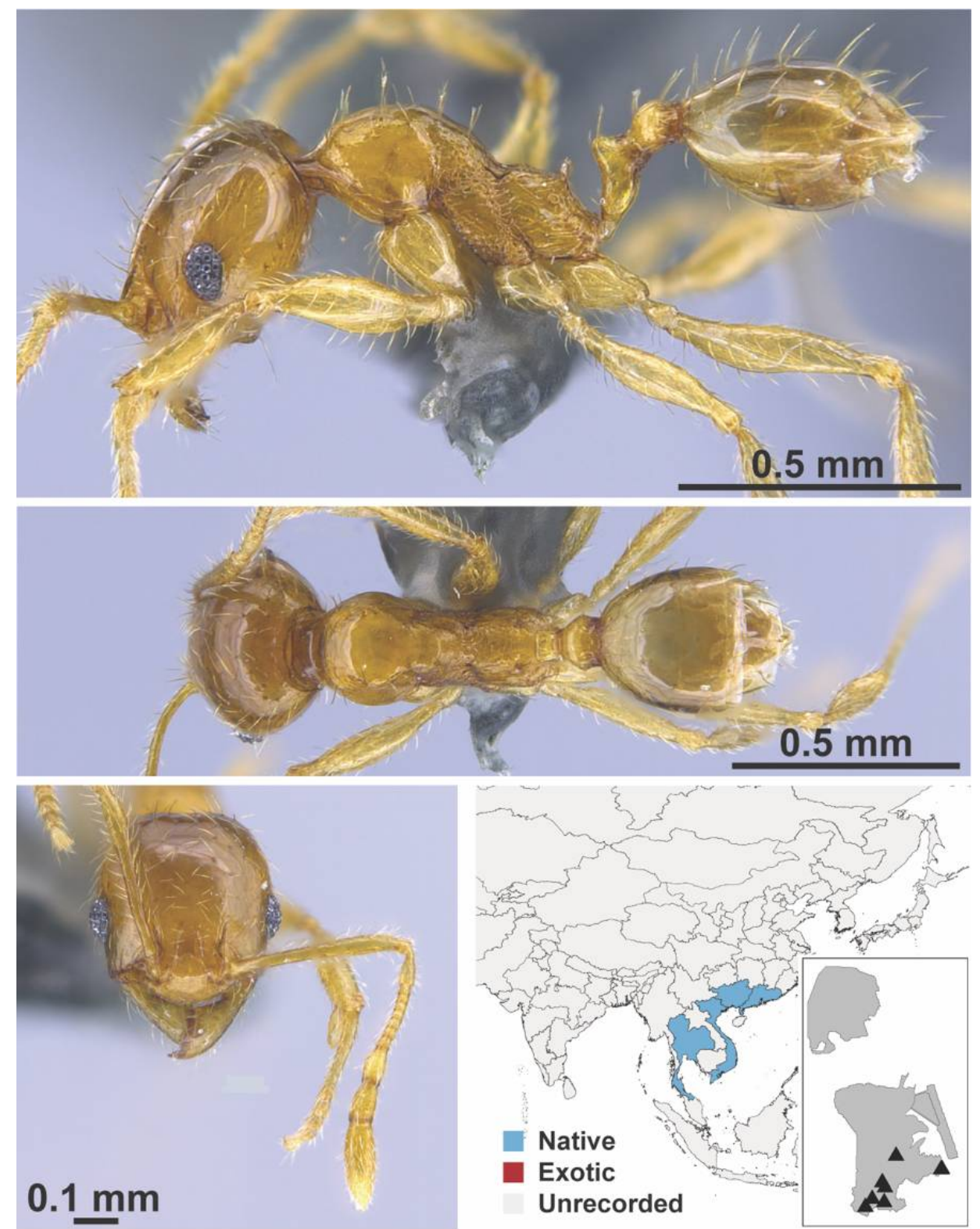

Figure A97. Pheidole taipoana Wheeler, 1928 worker (MAC_S04_LLSA_Sp.4, IBBL). 

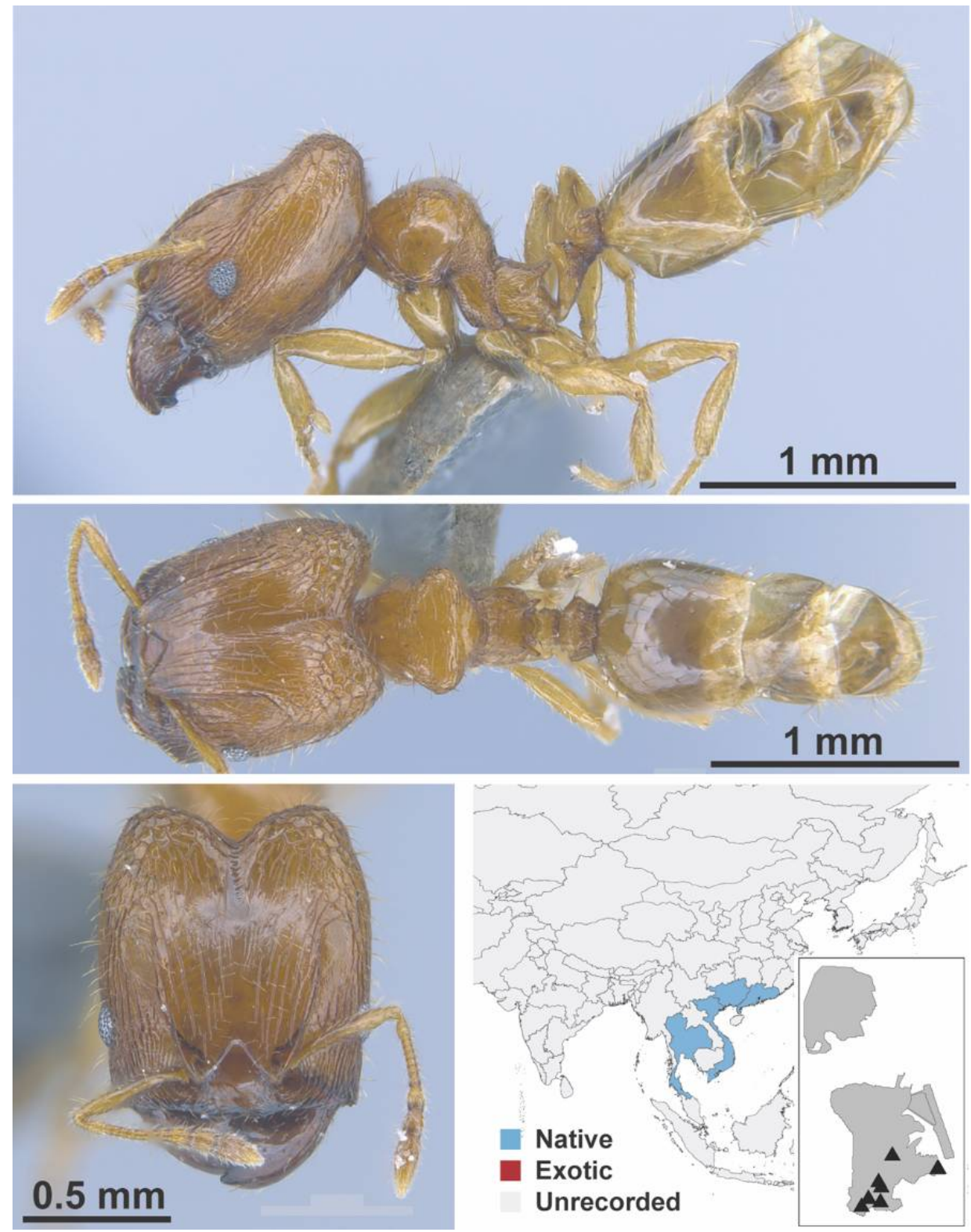

Figure A98. Pheidole taipoana Wheeler, 1928 major (MAC_S04_B07_sp.1_top, IBBL). 

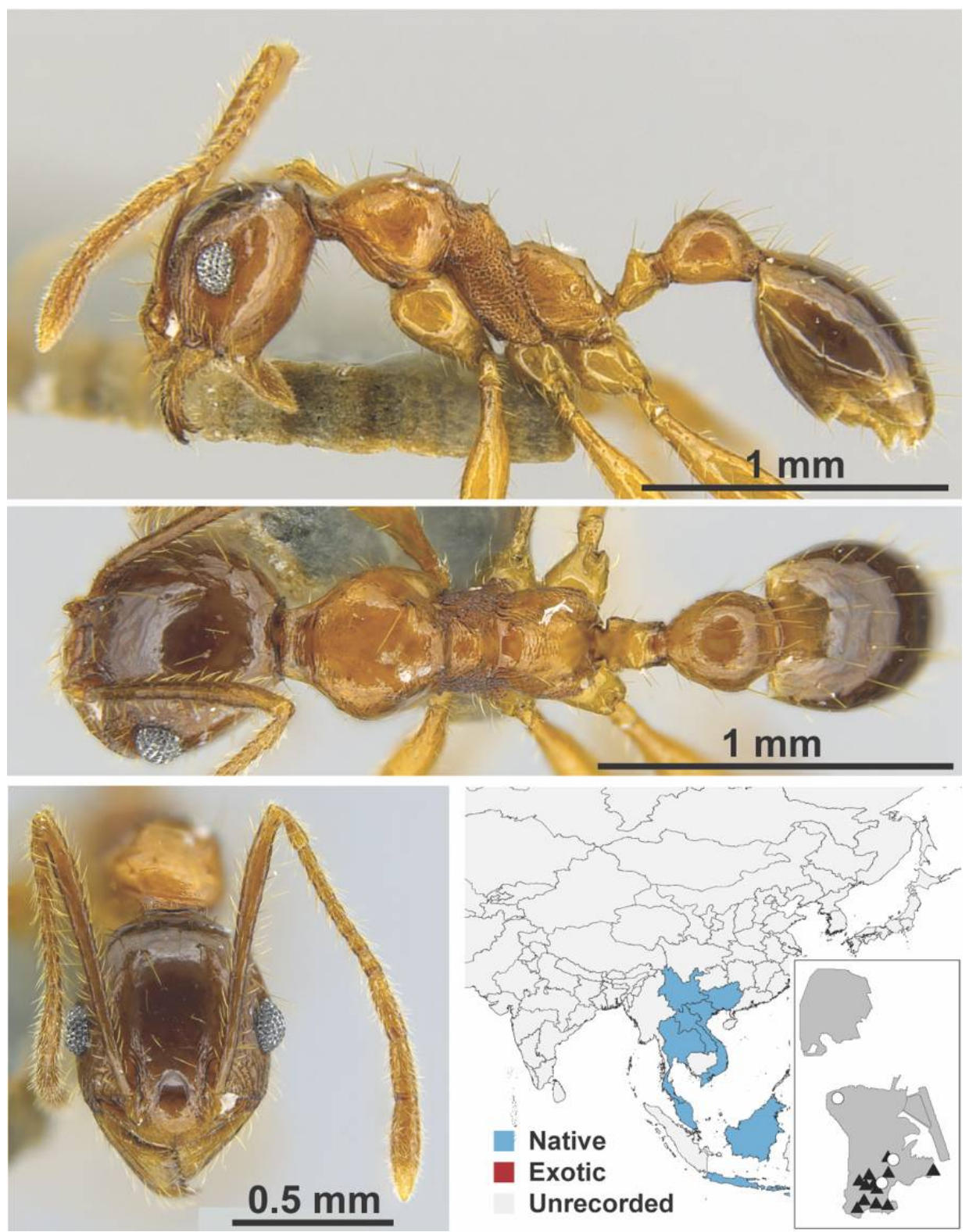

Figure A99. Pheidole tumida Eguchi, 2008 worker (MAC_S04_B06_sp.2_top, IBBL). 


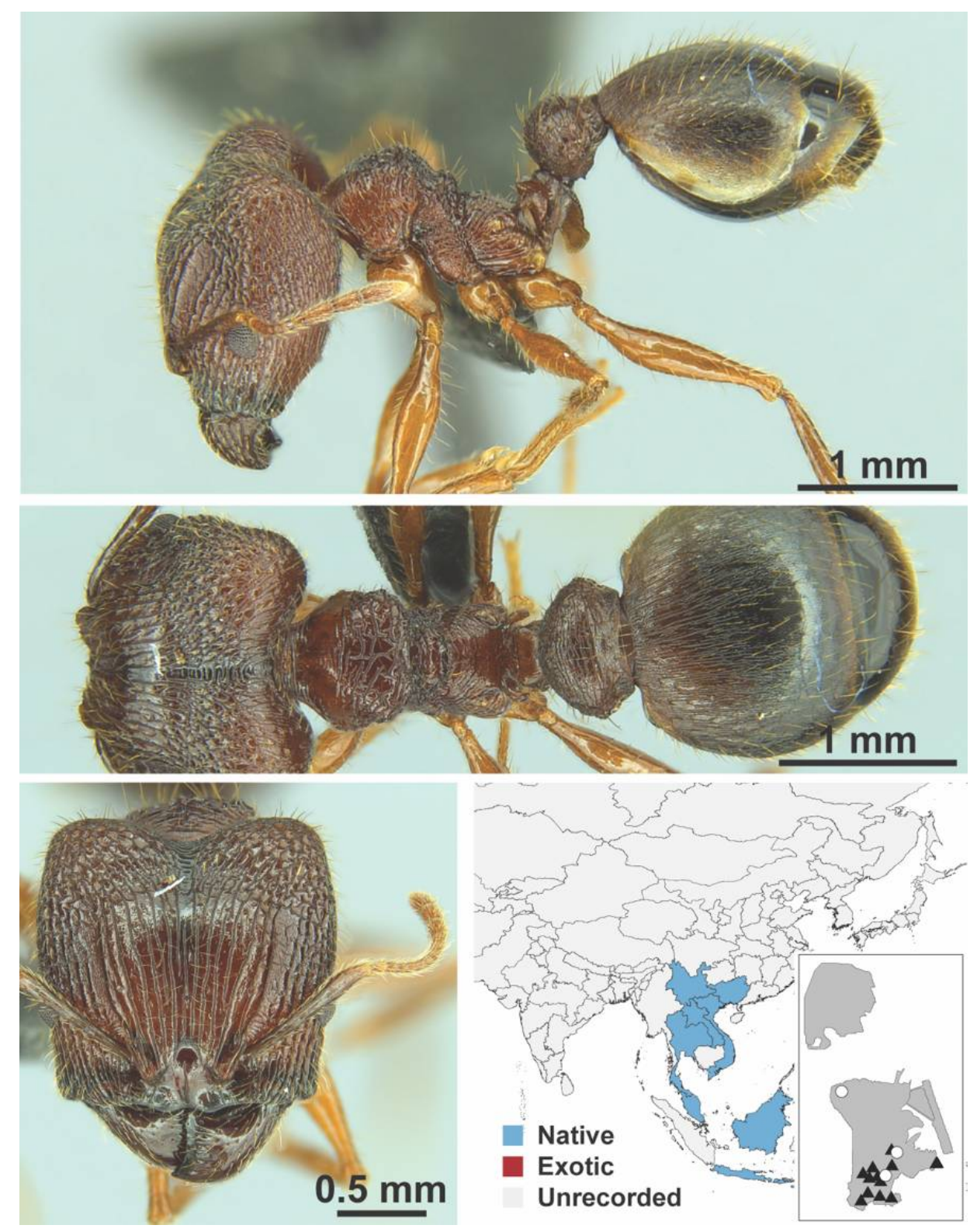

Figure A100. Pheidole tumida Eguchi, 2008 major (MAC_S7_GN1_H4_n1, IBBL). 

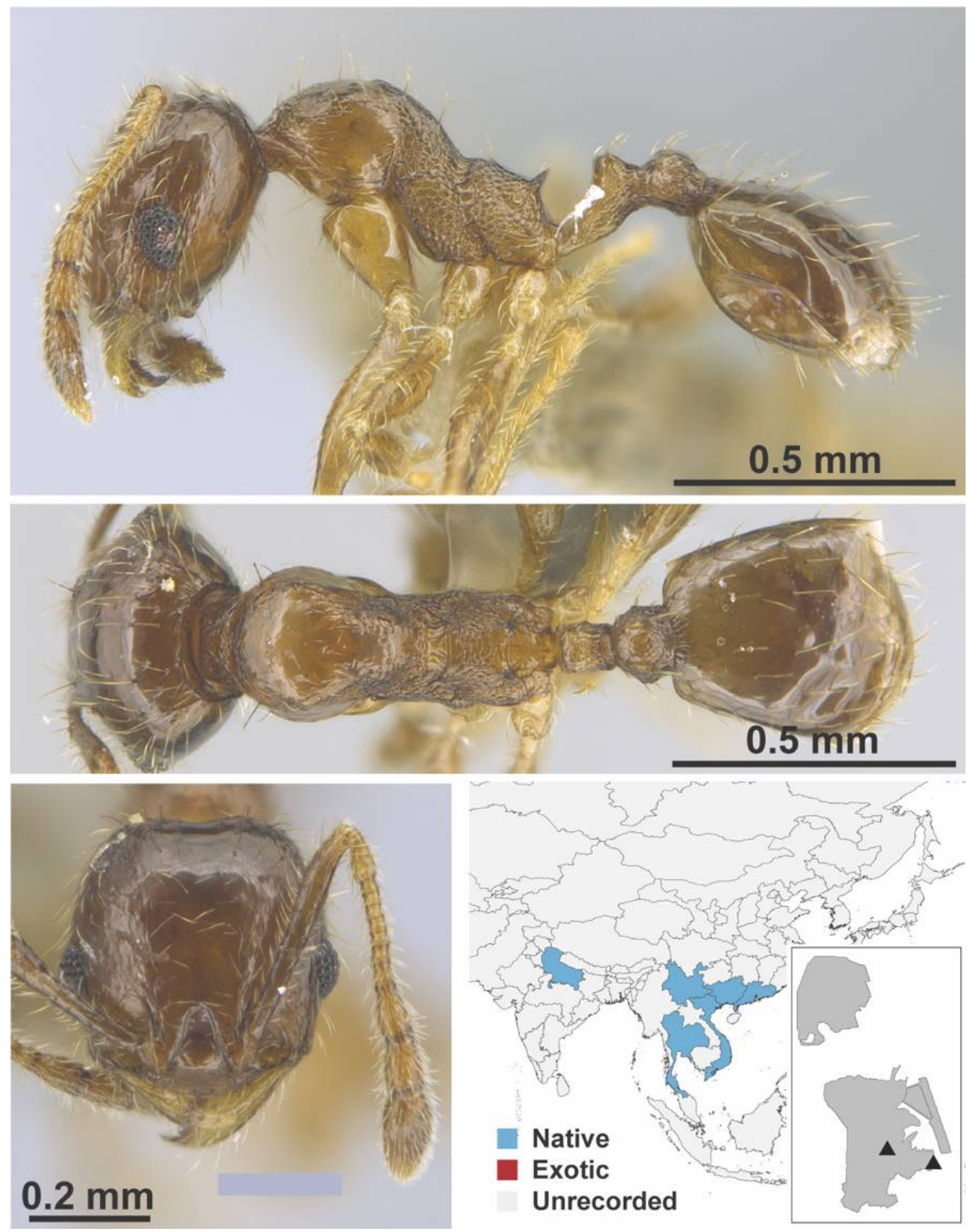

Figure A101. Pheidole vulgaris Eguchi, 2006 worker (MAC_S12_B04_sp.2_bottom, IBBL). 

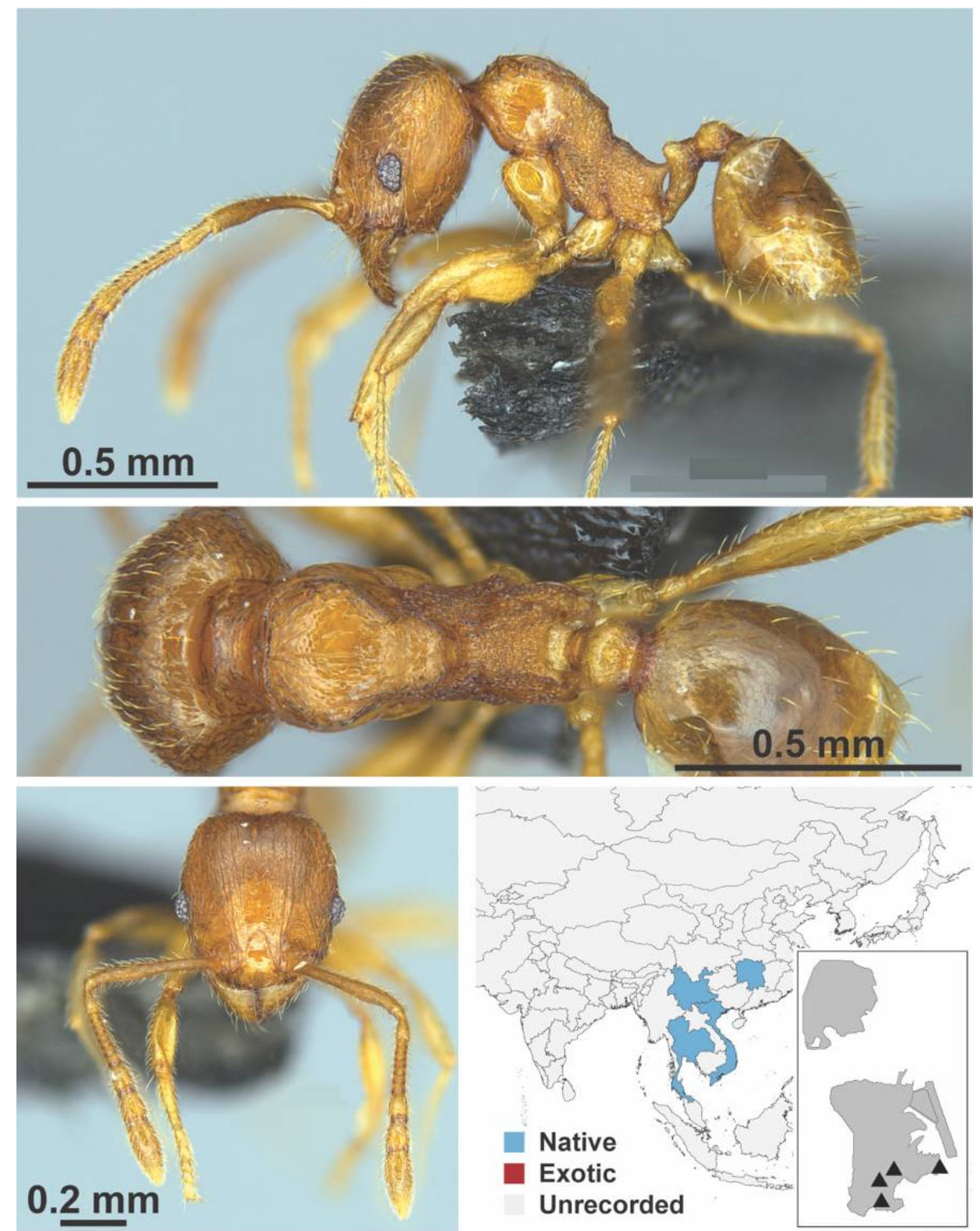

Figure A102. Pheidole zoceana Santschi, 1925 worker (MAC_S11_LLSA_sp.6, IBBL). 


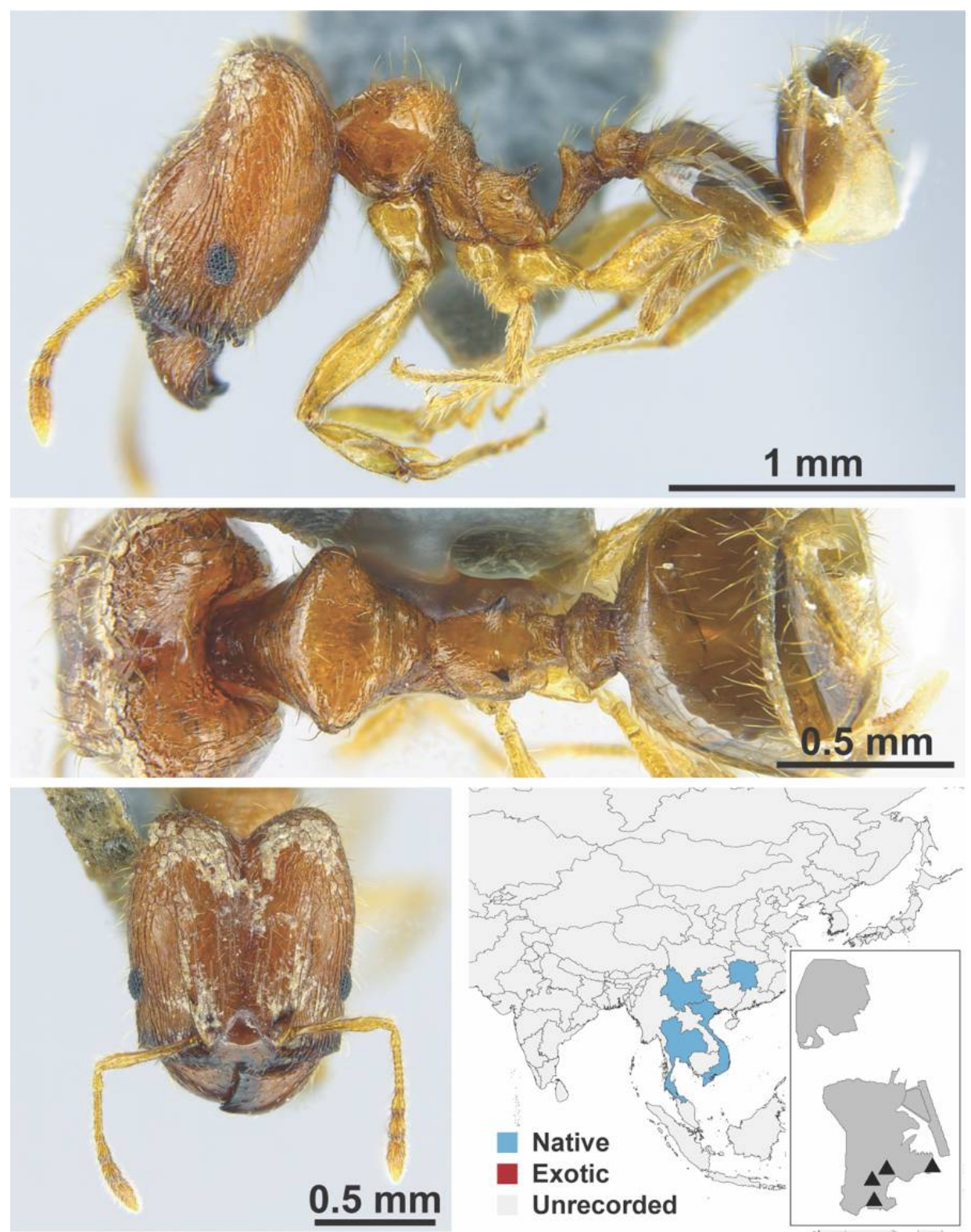

Figure A103. Pheidole zoceana Santschi, 1925 major (MAC_S17_LLSA_sp.1, IBBL). 

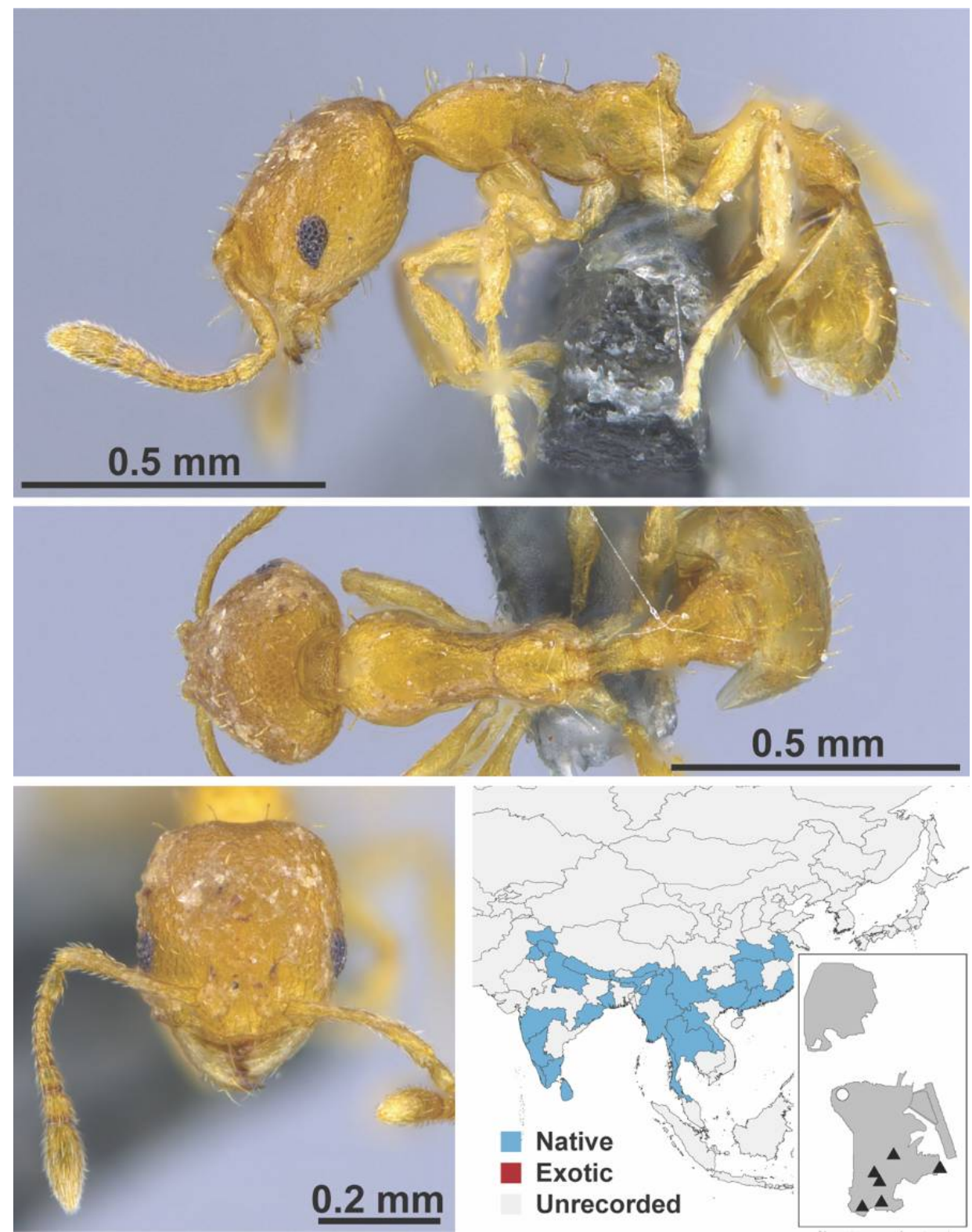

Figure A104. Recurvidris recurvispinosa Forel, 1890 (MAC_S12_LLSA_Sp.9, IBBL). 

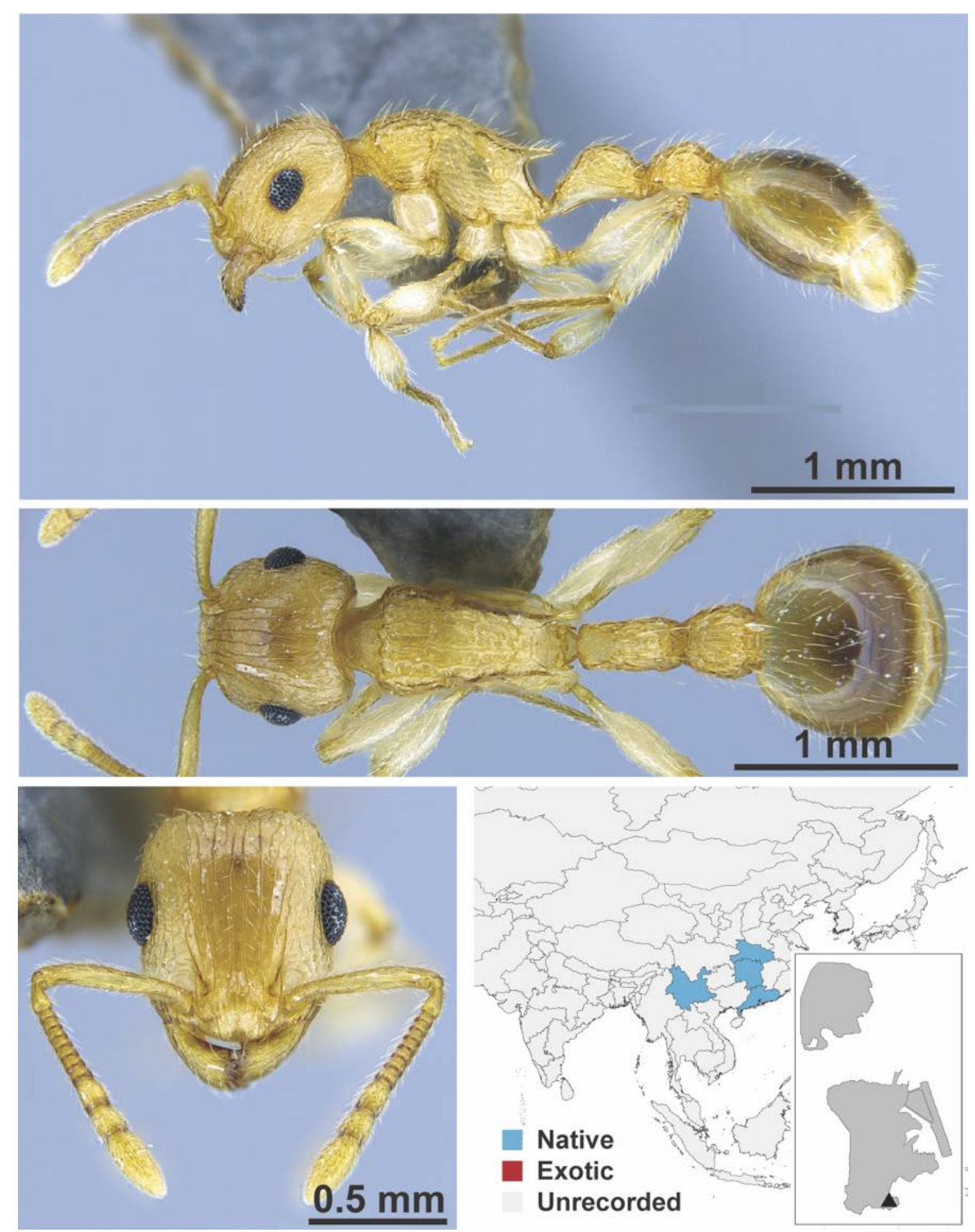

Figure A105. Rotastruma stenoceps Bolton, 1991 worker (MAC_S15_LLSA_sp.6, IBBL). 

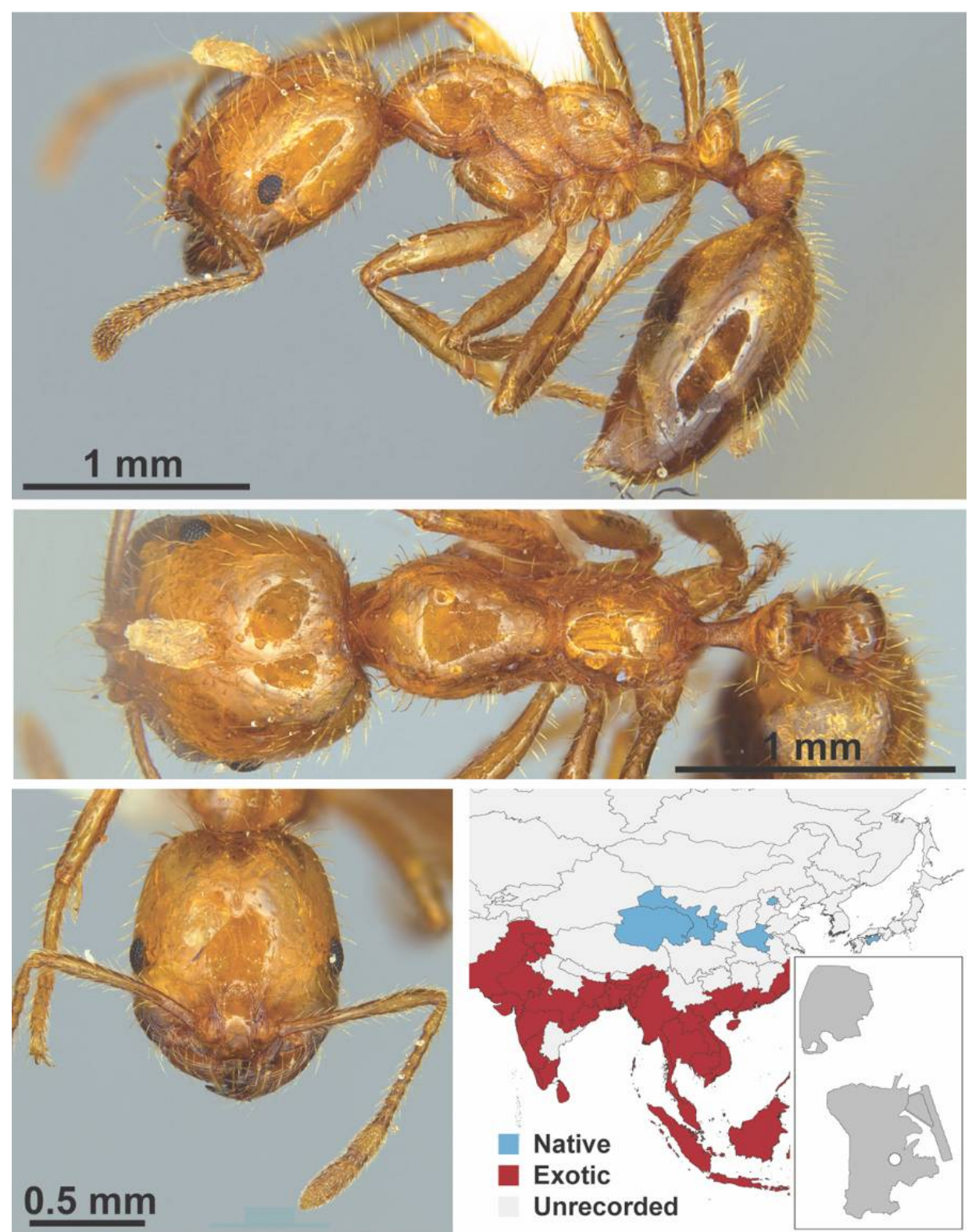

Figure A106. Solenopsis geminata Fabricius, 1804 worker (Solenopsis geminata, IBBL). 

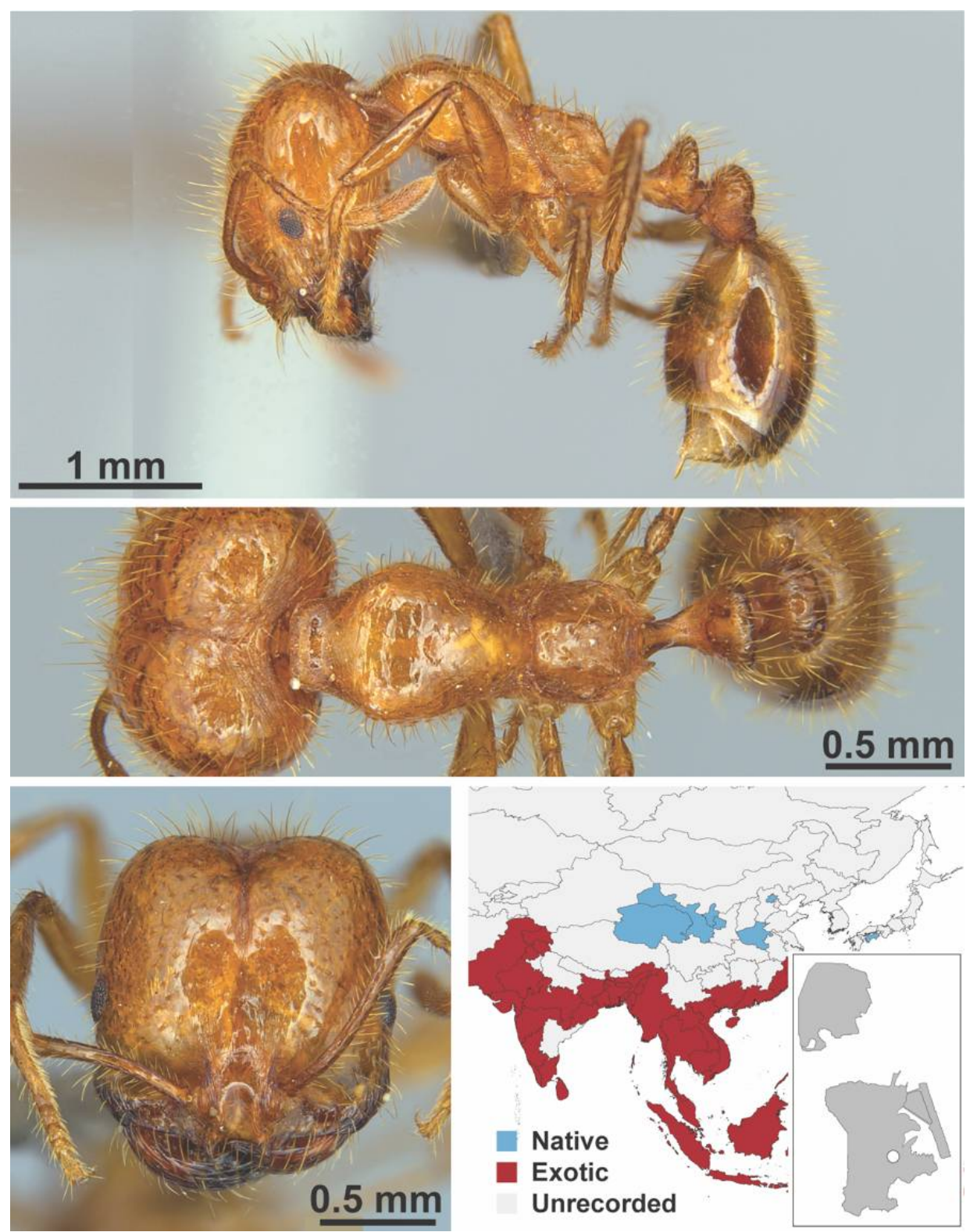

Figure A107. Solenopsis geminata Fabricius, 1804 major (Solenopsis geminata, IBBL). 


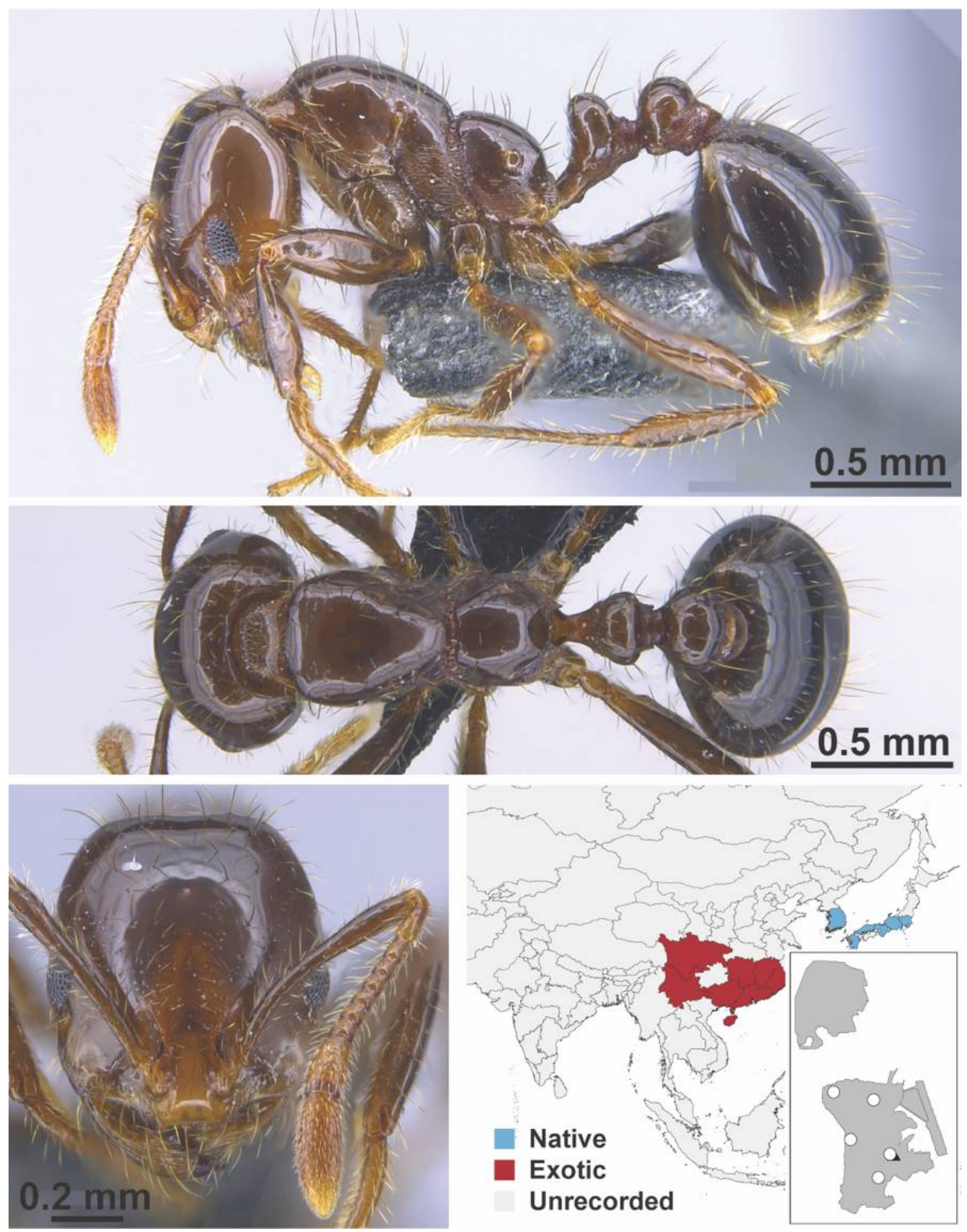

Figure A108. Solenopsis invicta Buren, 1972 worker (MAC_S09_LLSP_Sp.5, IBBL). 


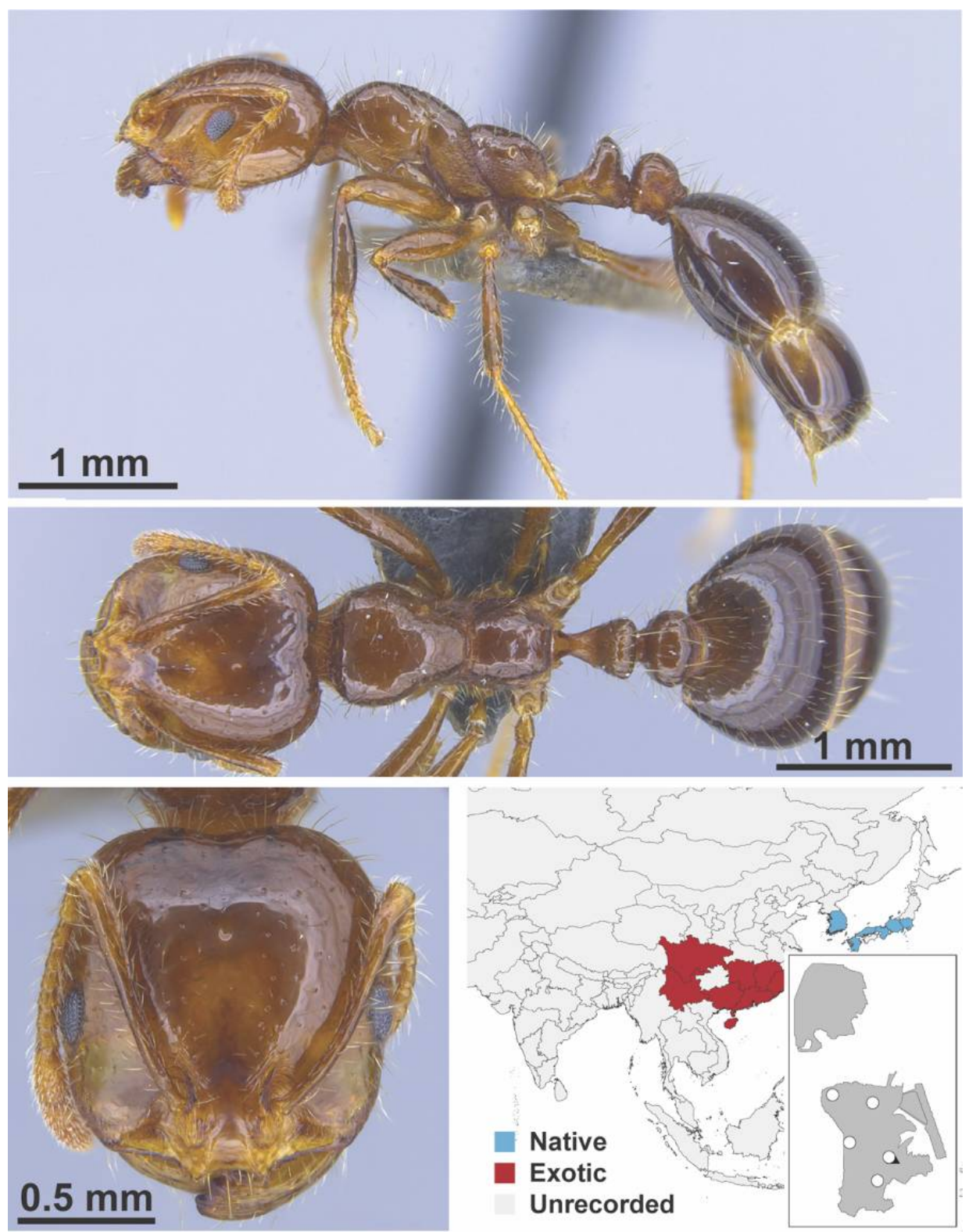

Figure A109. Solenopsis invicta Buren, 1972 major (MAC_S09_B05_sp.1_bottom, IBBL). 

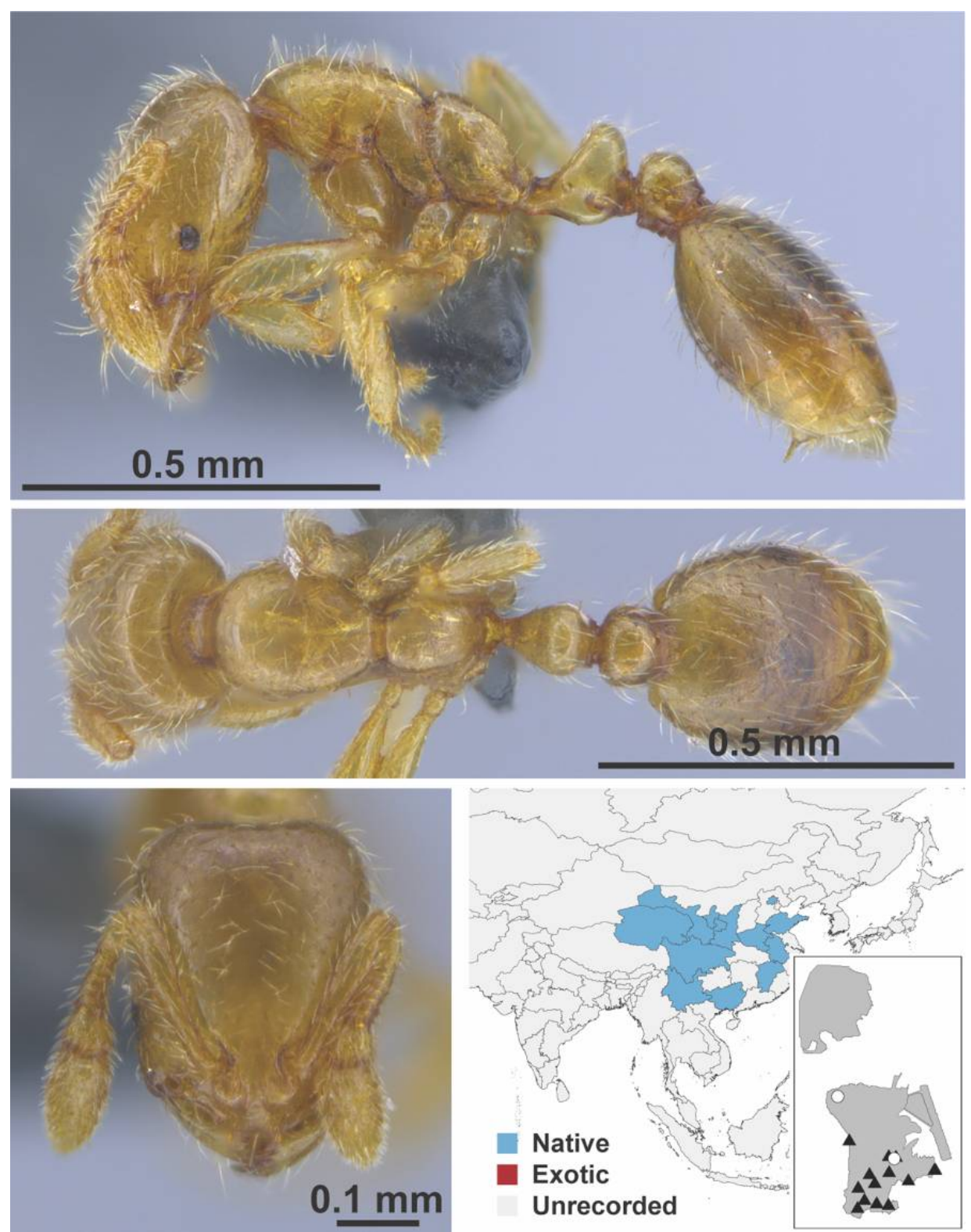

Figure A110. Solenopsis jacoti Wheeler, 1923 worker (MAC_S12_q3_37.5_sp.2_top, IBBL). 

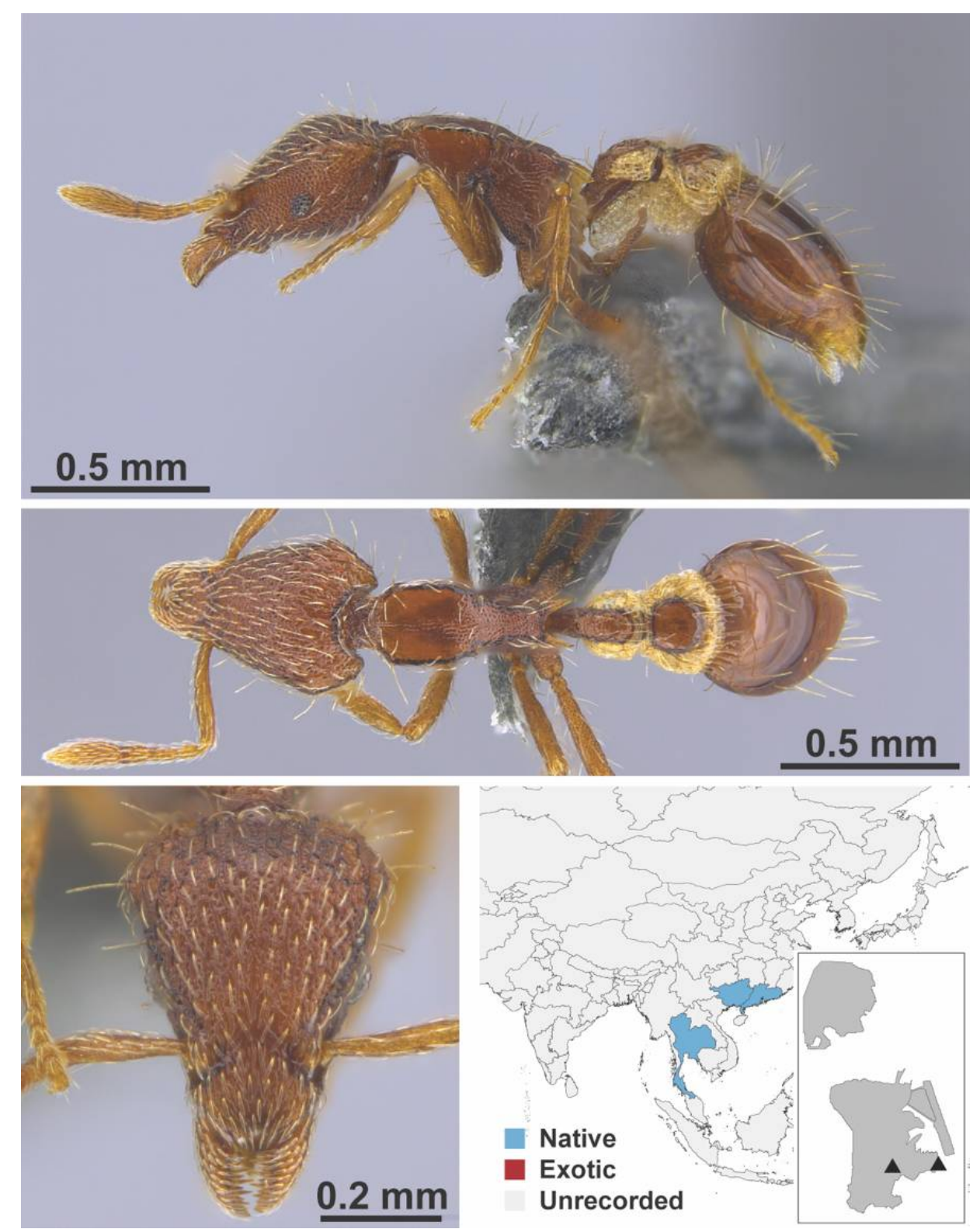

Figure A111. Strumigenys elegantula Terayama \& Kubota, 1989 worker (MAC_S04_LLSP_sp.9, IBBL). 

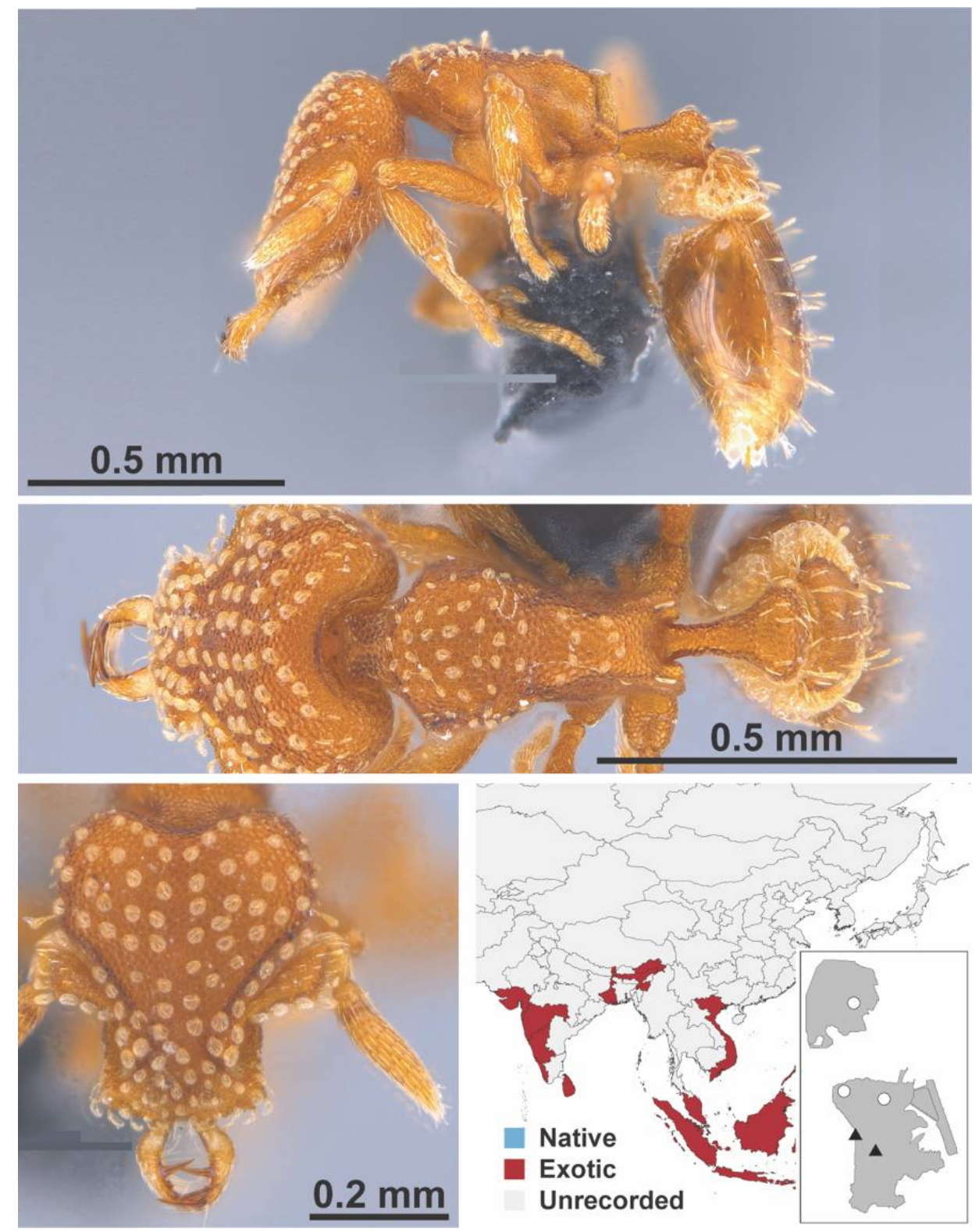

Figure A112. Strumigenys emmae Emery, 1890 worker (MAC_S20_LLSP_Sp.7, IBBL). 

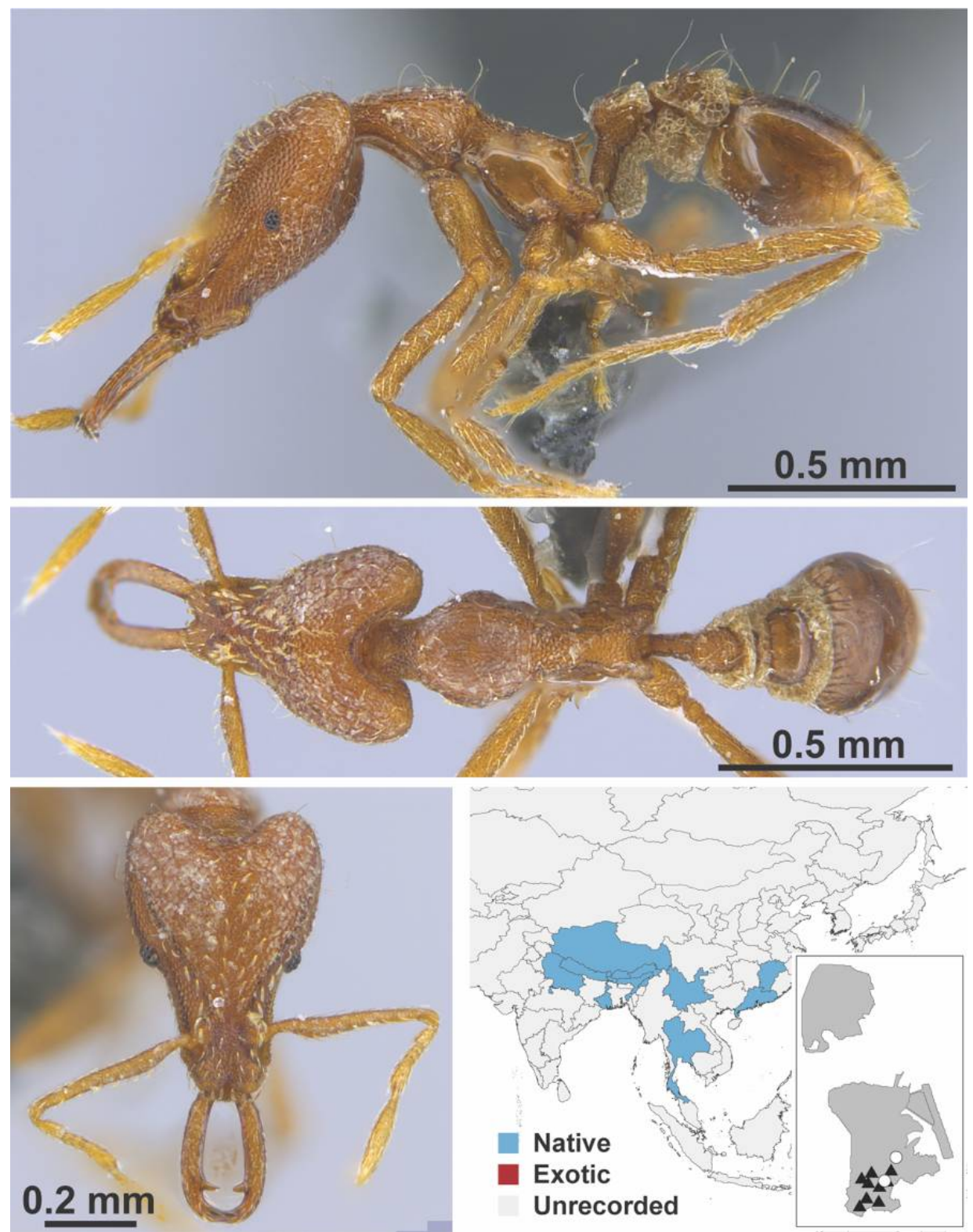

Figure A113. Strumigenys exilirhina Bolton, 2000 worker (MAC_S01_LLSA_Sp.3, IBBL). 

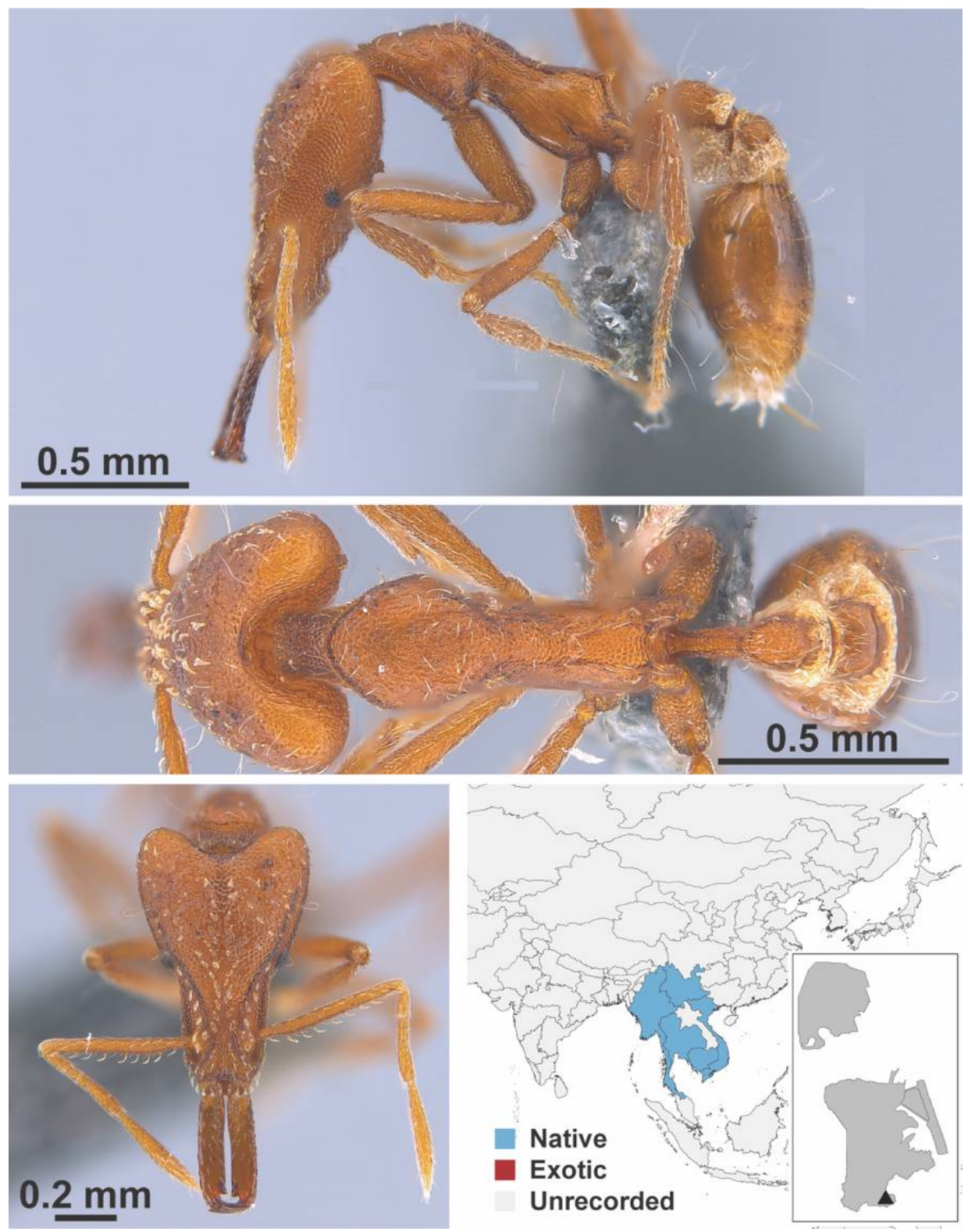

Figure A114. Strumigenys feae Emery, 1895 worker (MAC_S15_LLSP_Sp.8, IBBL). 

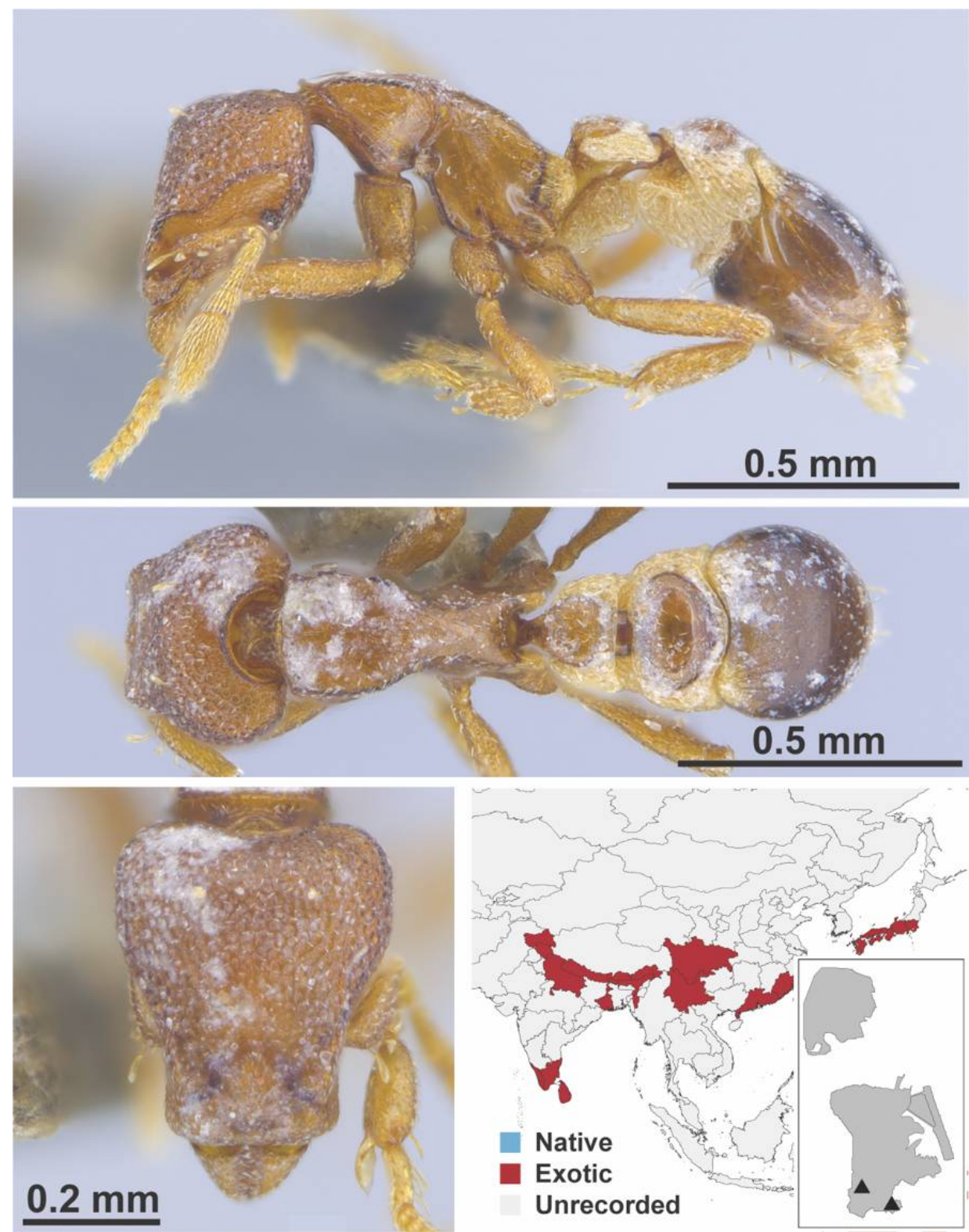

Figure A115. Strumigenys membranifera Emery, 1869 worker (MAC_S15_GN3_H3_n1_top, IBBL). 

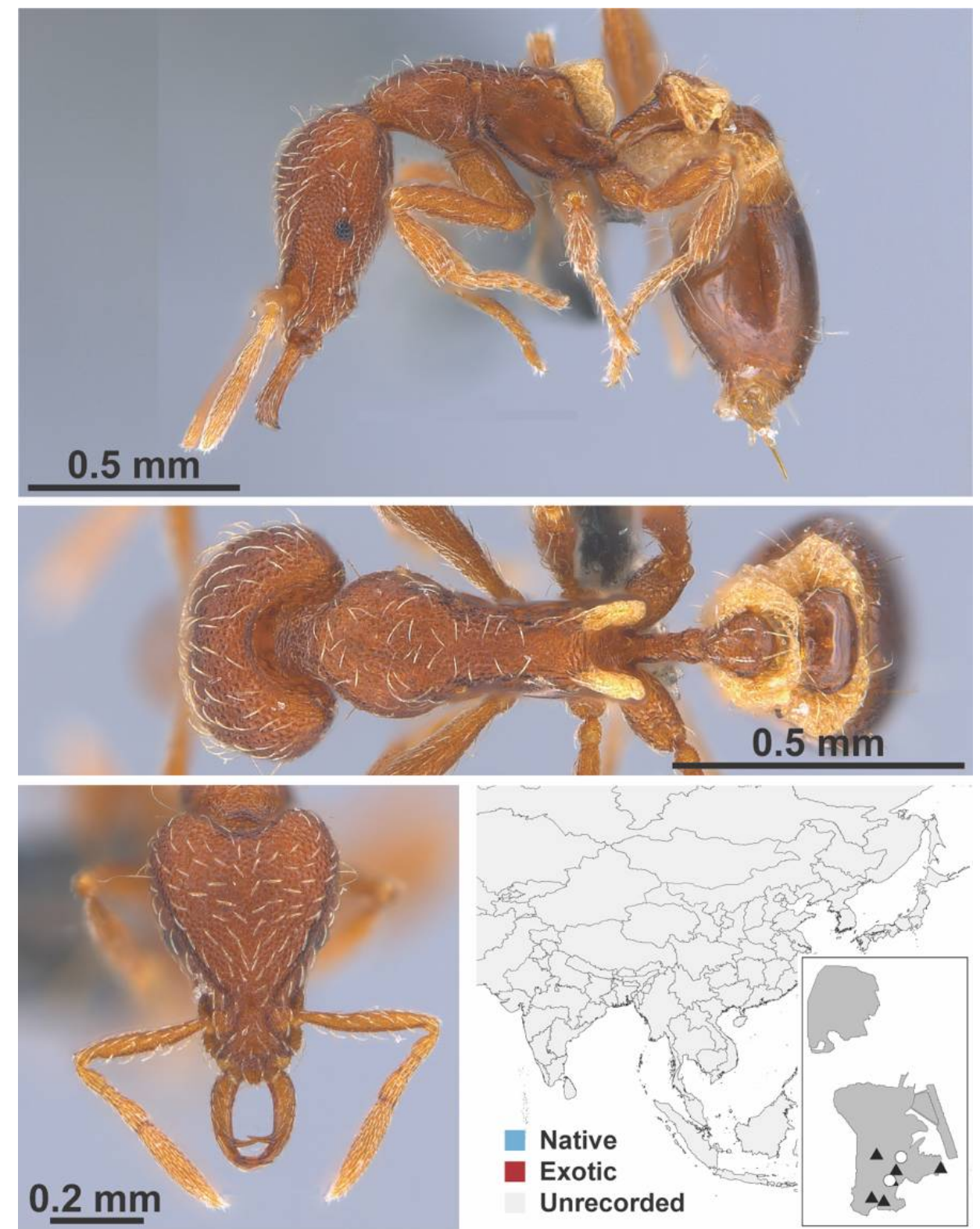

Figure A116. Strumigenys minutula Terayama \& Kubota, 1989 worker (MAC_S14_LLSP_Sp.4, IBBL). 

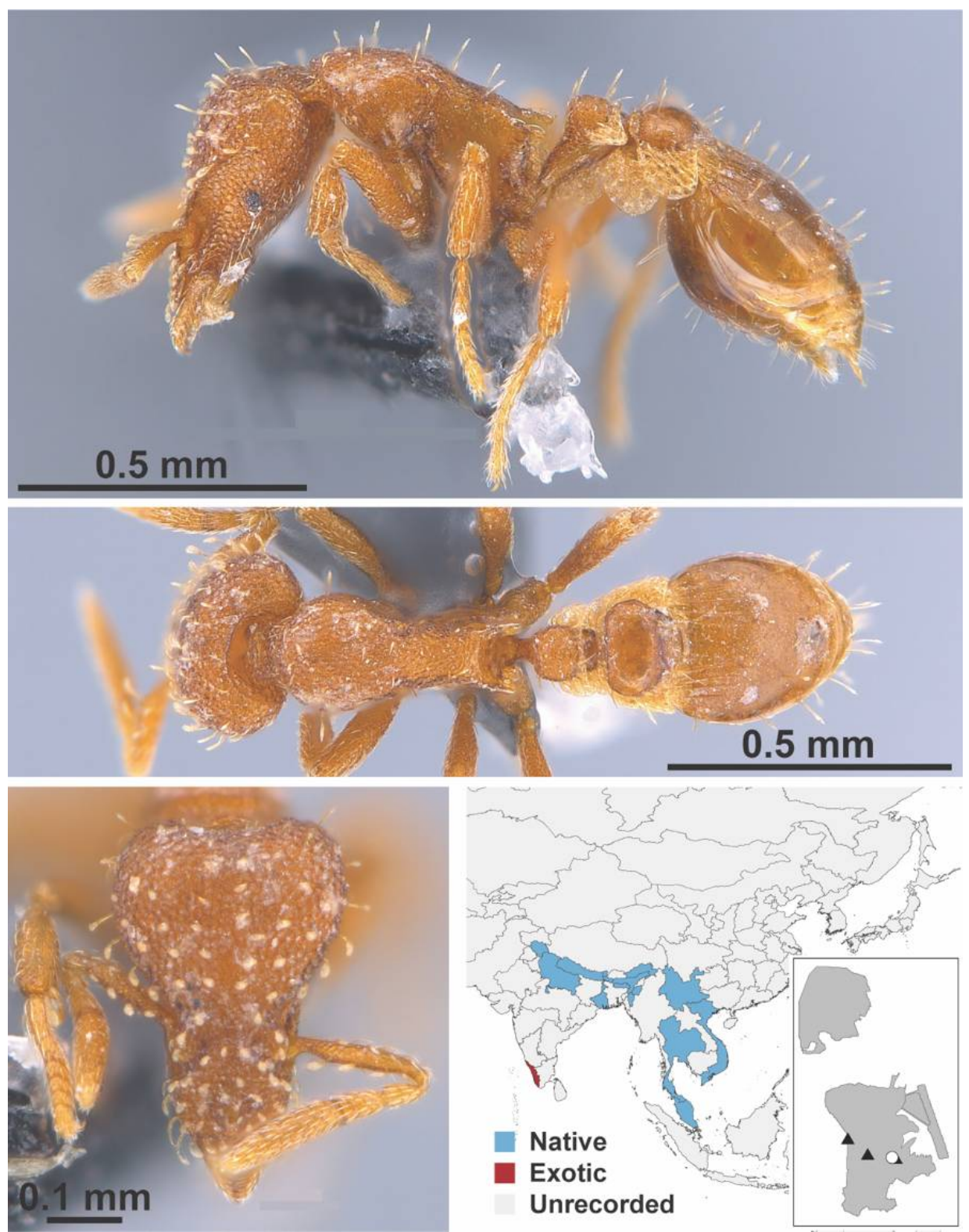

Figure A117. Strumigenys nepalensis Baroni Urbani \& De Andrade, 1994 worker (MAC_S19_ LLSP_Sp.3, IBBL). 

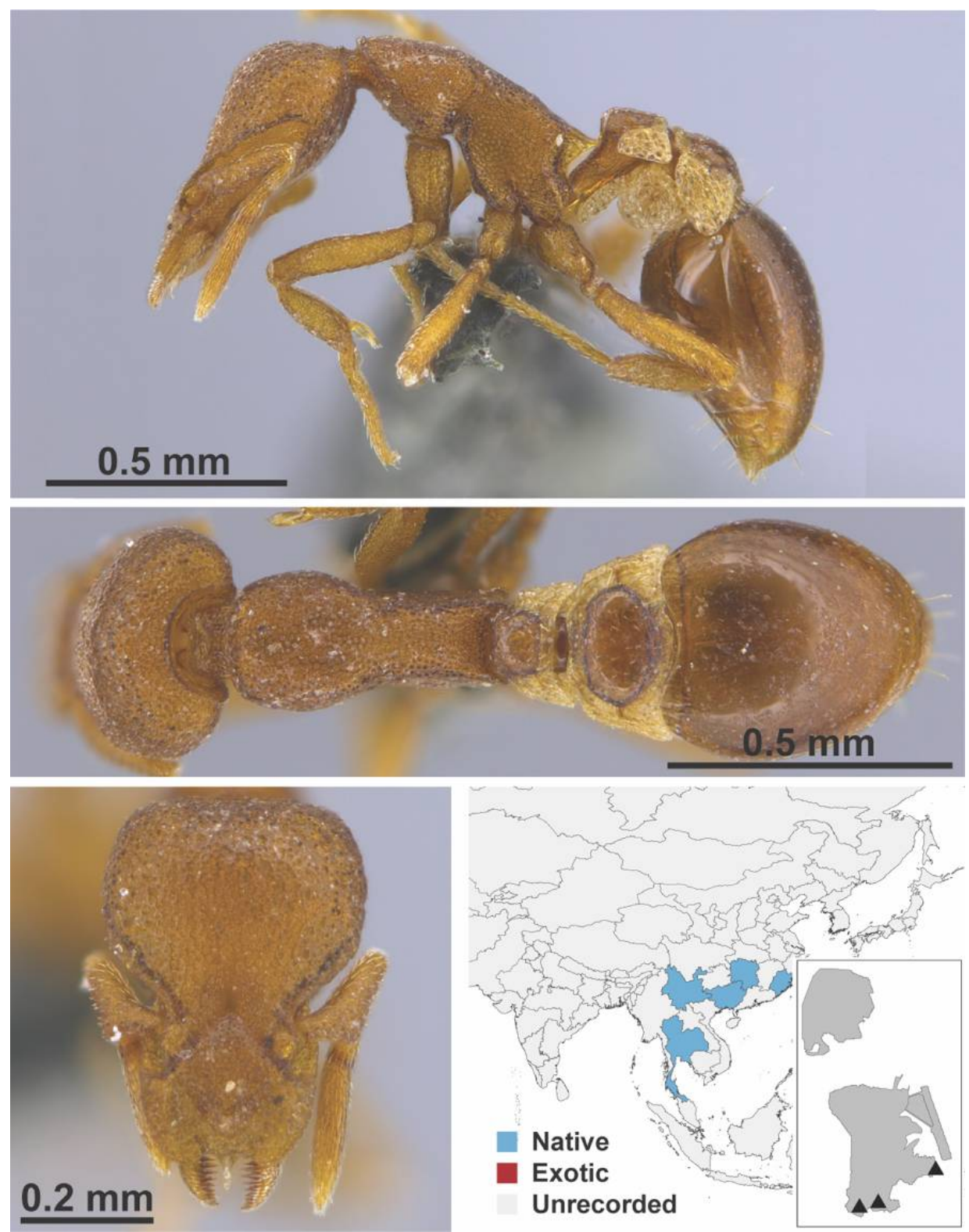

Figure A118. Strumigenys sauteri Forel, 1912 worker (MAC_S04_LLSP_sp.2, IBBL). 

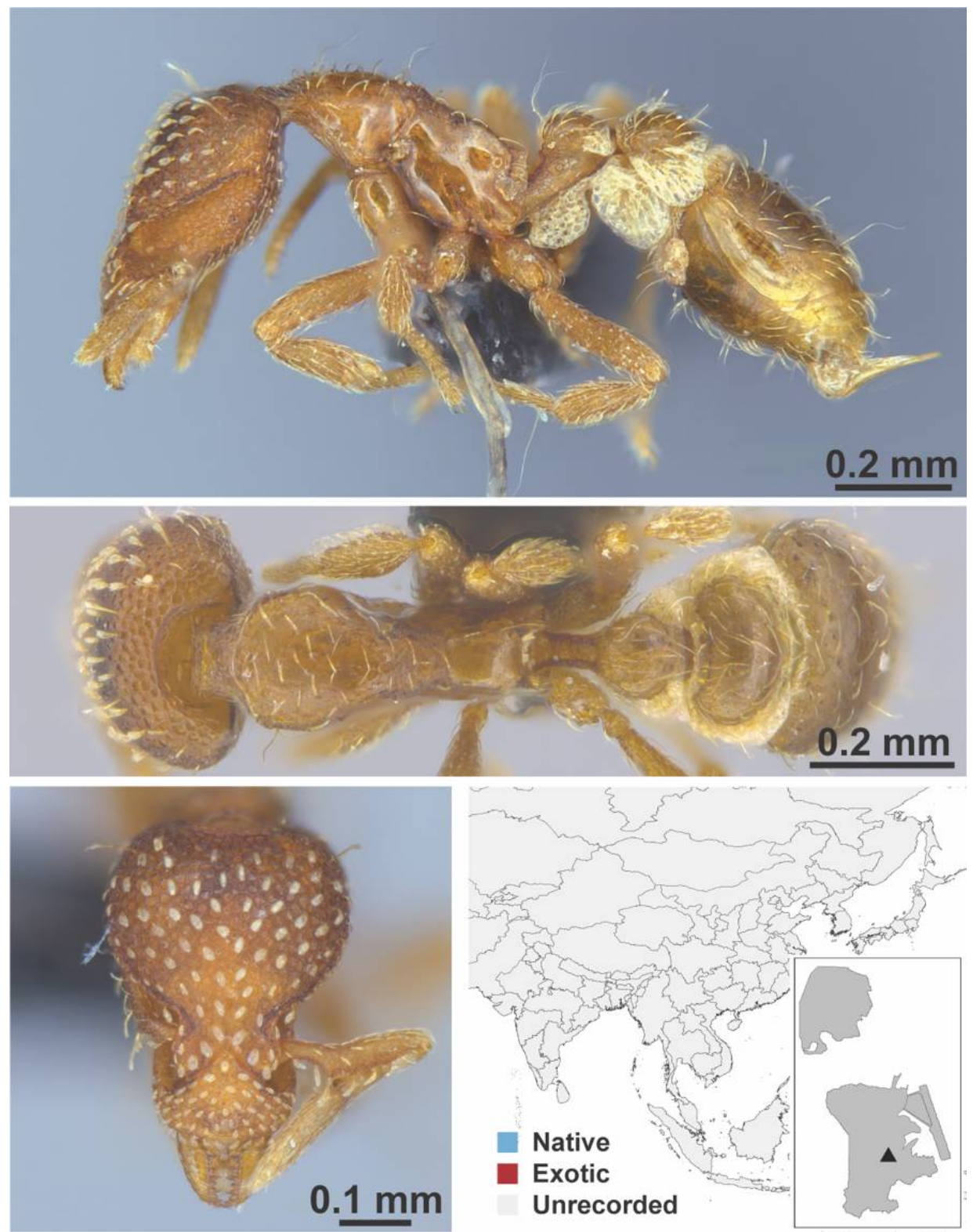

Figure A119. Strumigenys subterranea Brassard, Leong \& Guénard, 2020 worker (MAC_S12_q4_ 12.5_sp.2, IBBL). 

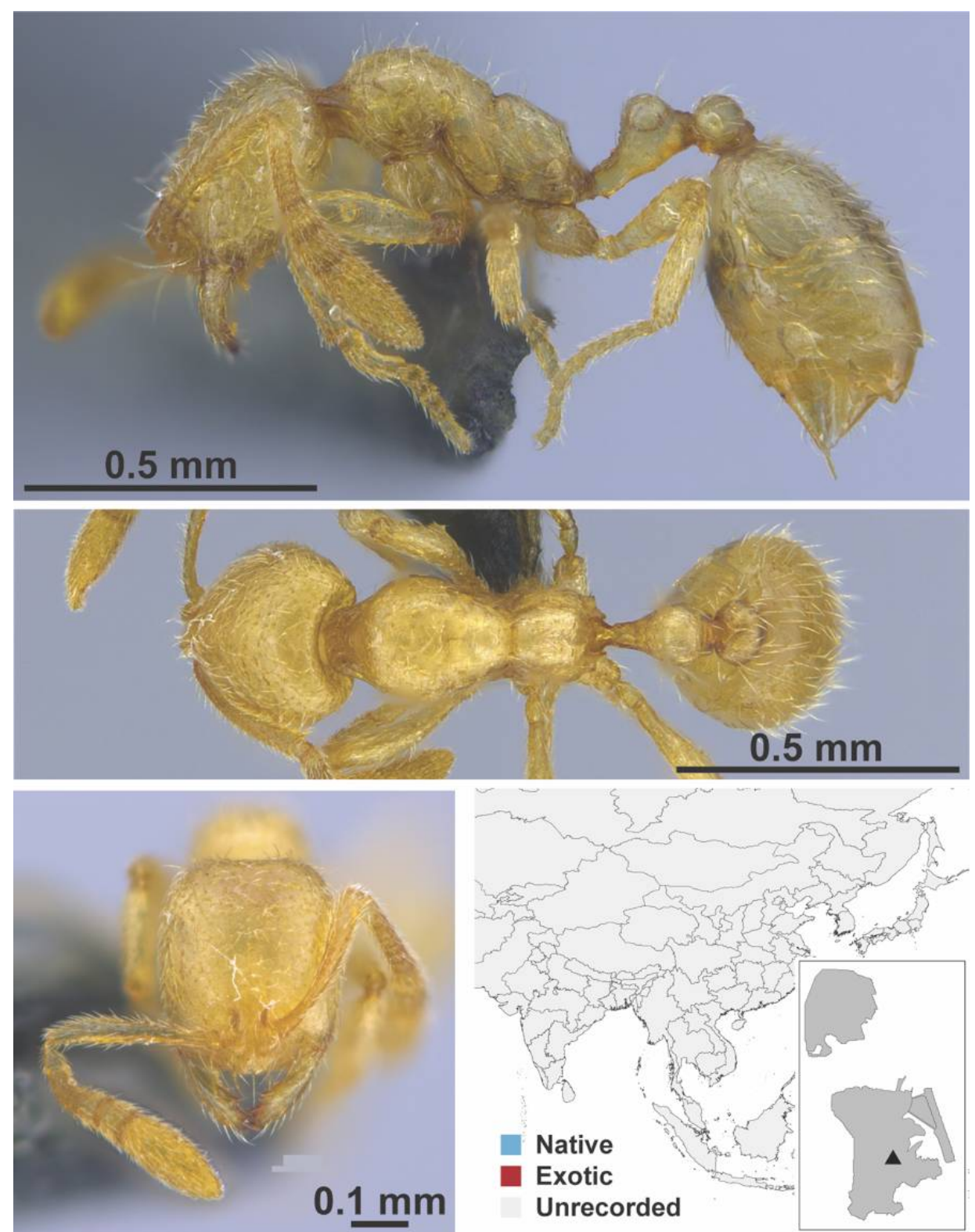

Figure A120. Syllophopsis nr. cryptobia worker (MAC_S12_q3_37.5_sp.3, IBBL). 

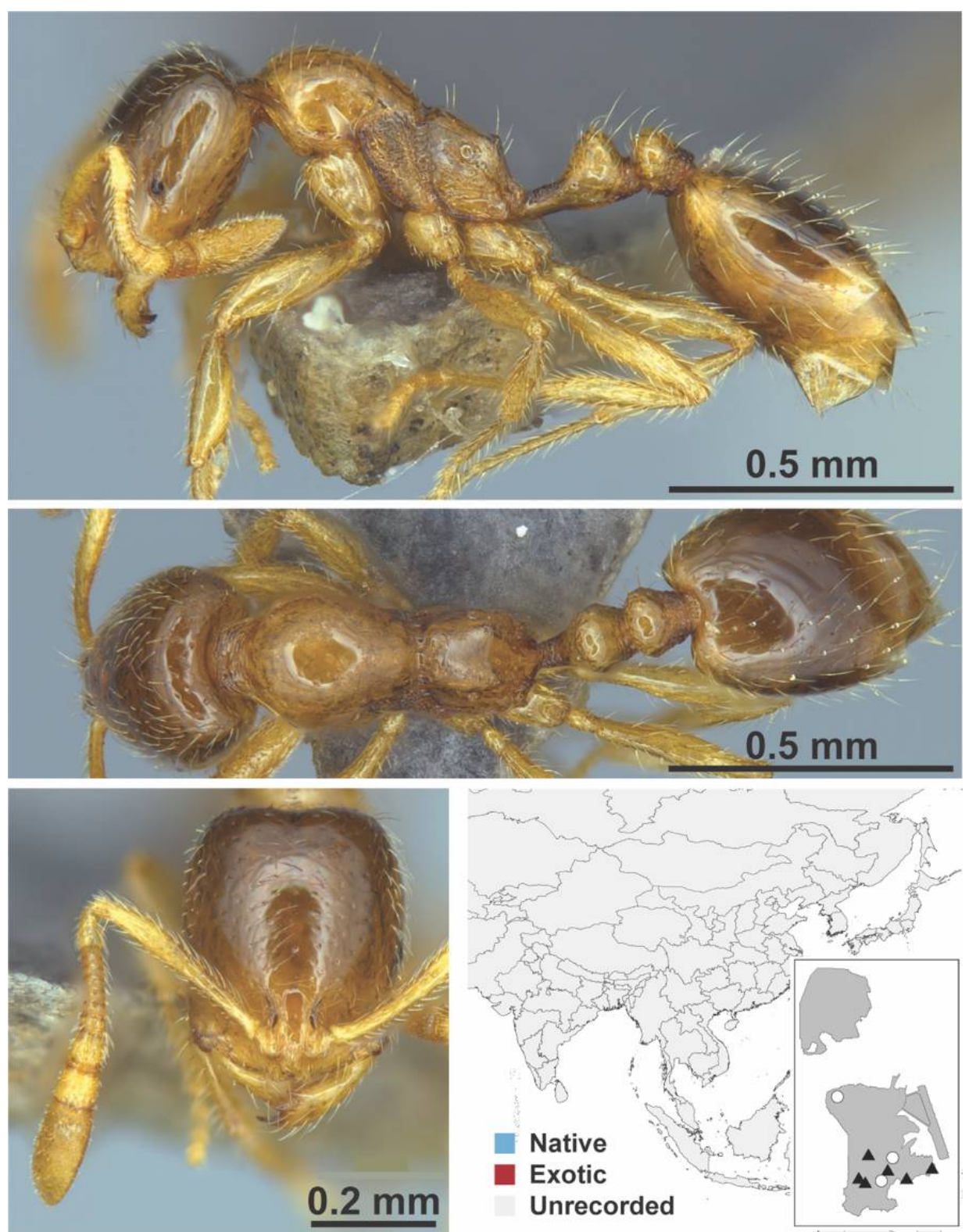

Figure A121. Syllophopsis sp. mo01 nr. sechellensis Emery, 1894 worker (Syllophopsis sp. mo01 nr. Sechellensis, CML collection). 

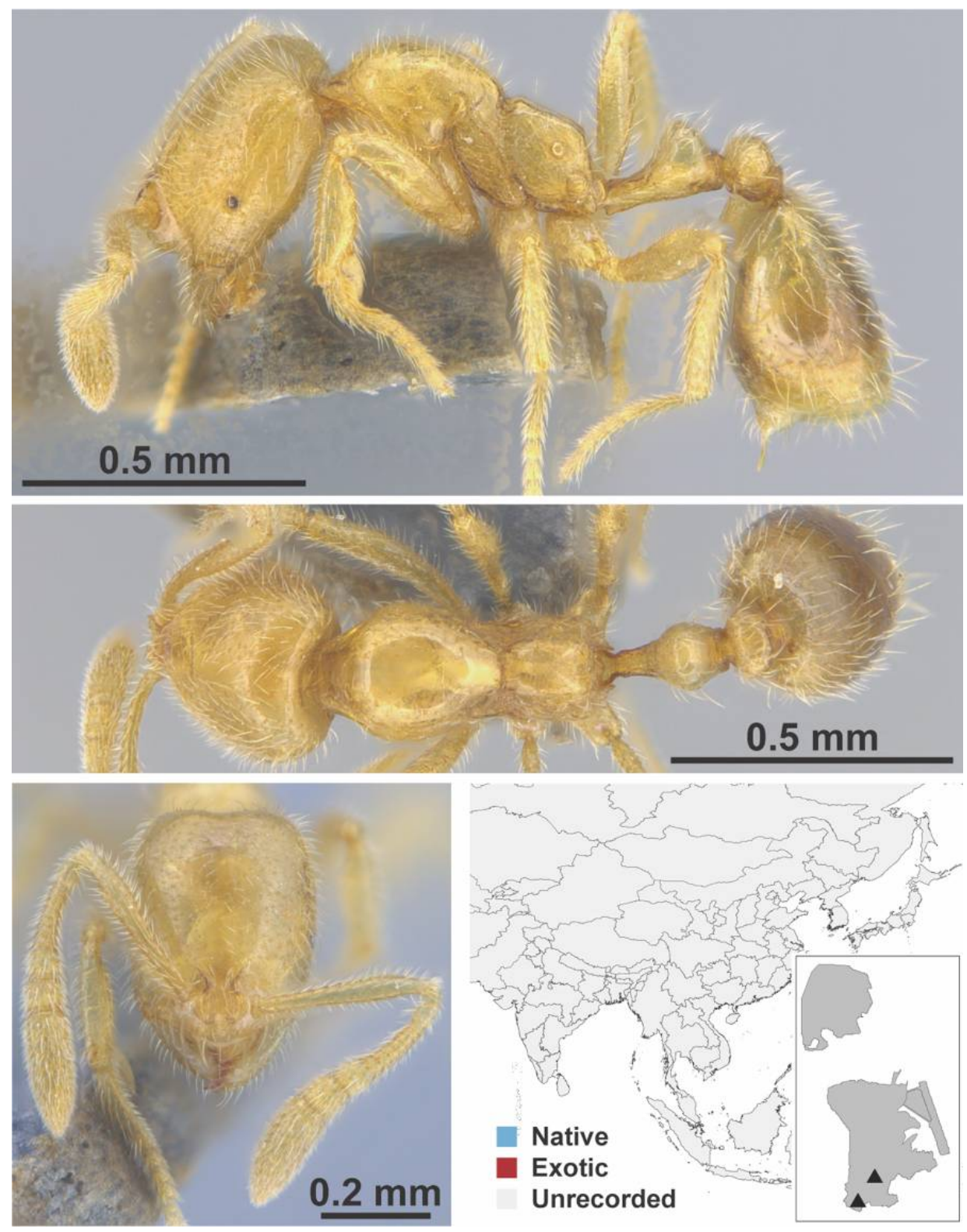

Figure A122. Syllophopsis sp. 1 FB worker (MAC_S18_q3_12.5_sp.4, IBBL). 

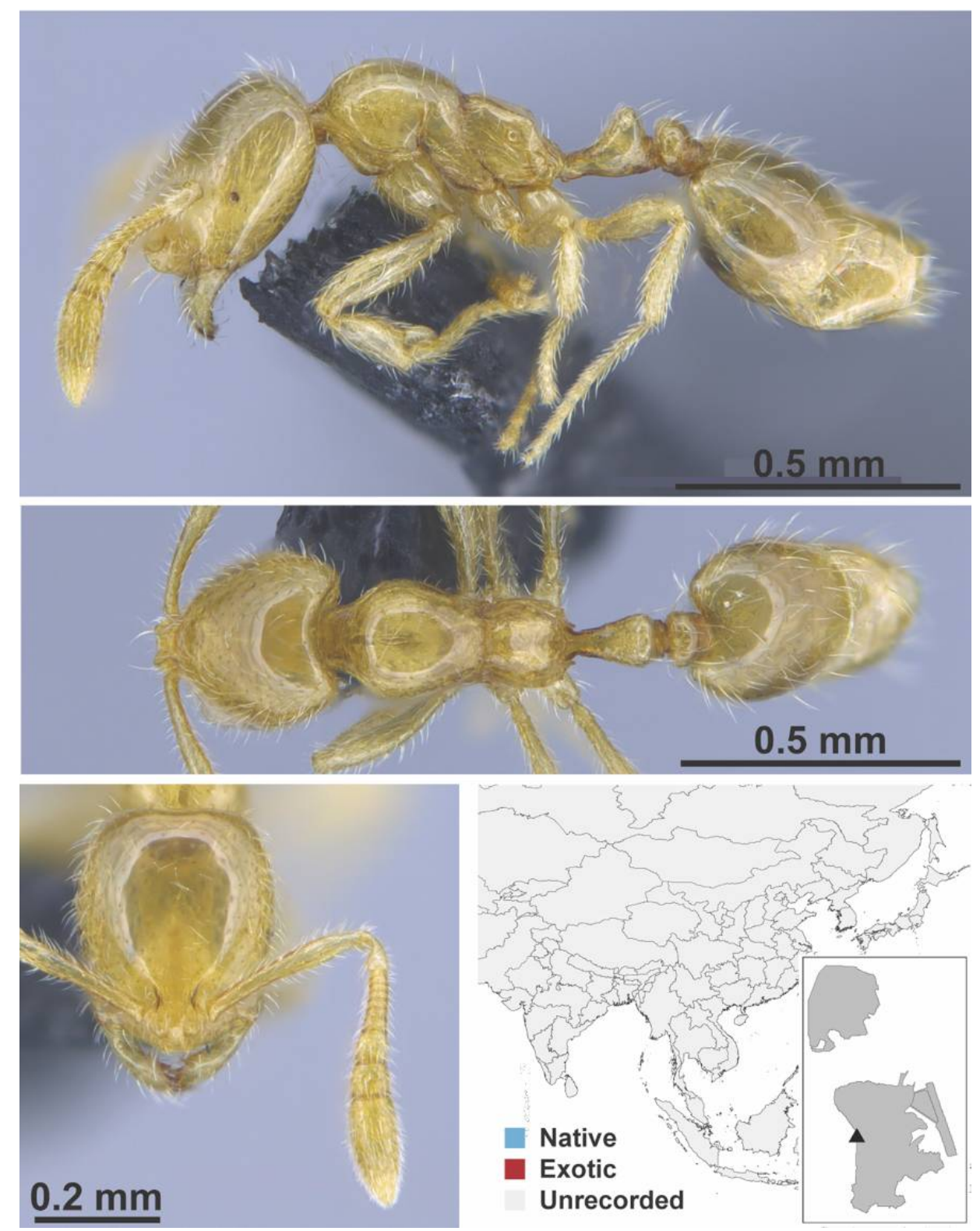

Figure A123. Syllophopsis sp. 2 FB worker (MAC_S20_LLSP_sp.10_top, IBBL). 


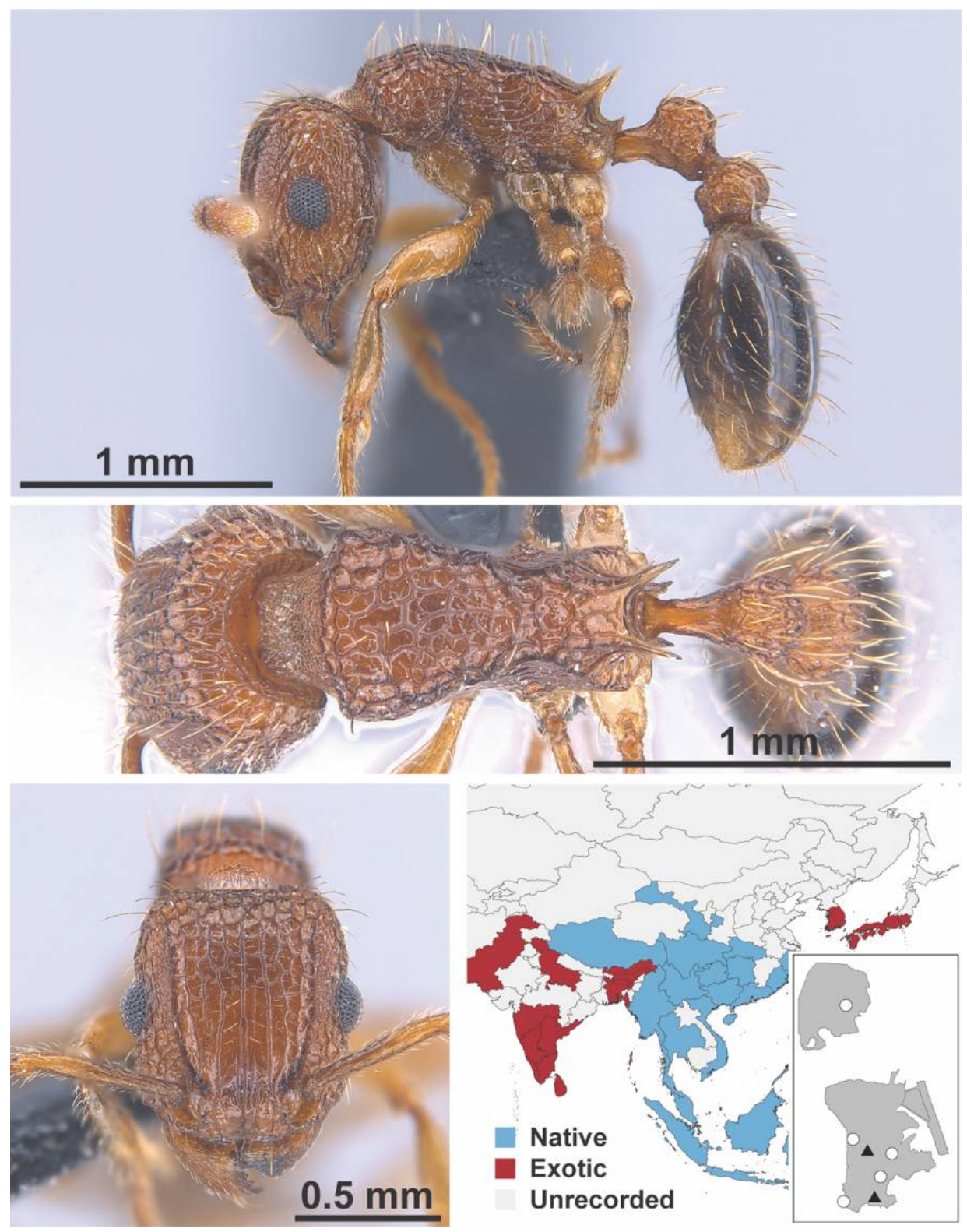

Figure A124. Tetramorium bicarinatum Nylander, 1846 worker (MAC_S19_LLSP_Sp.9, IBBL). 


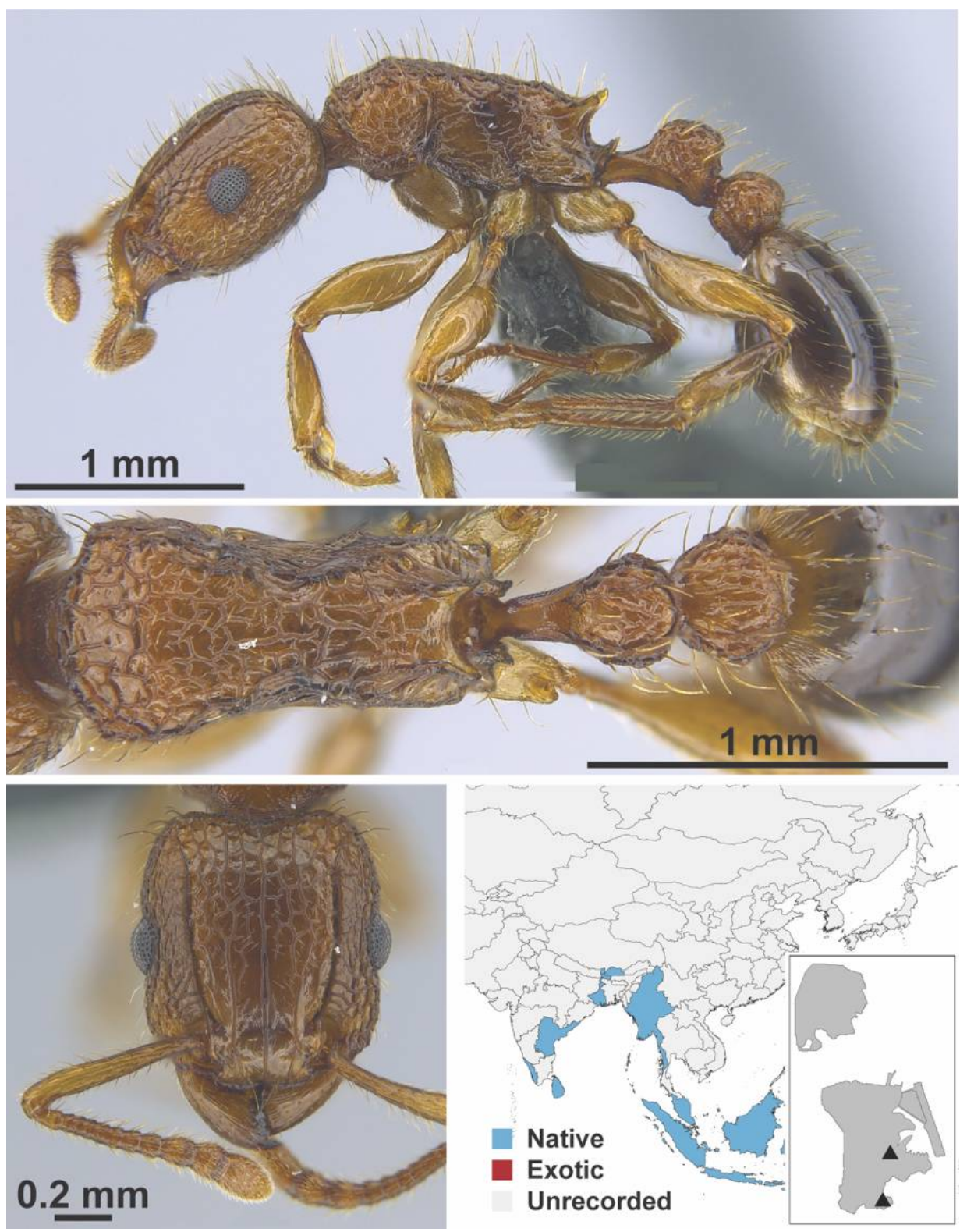

Figure A125. Tetramorium indicum Forel, 1913 worker (MAC_S08_T3_1m_sp.1, IBBL). 

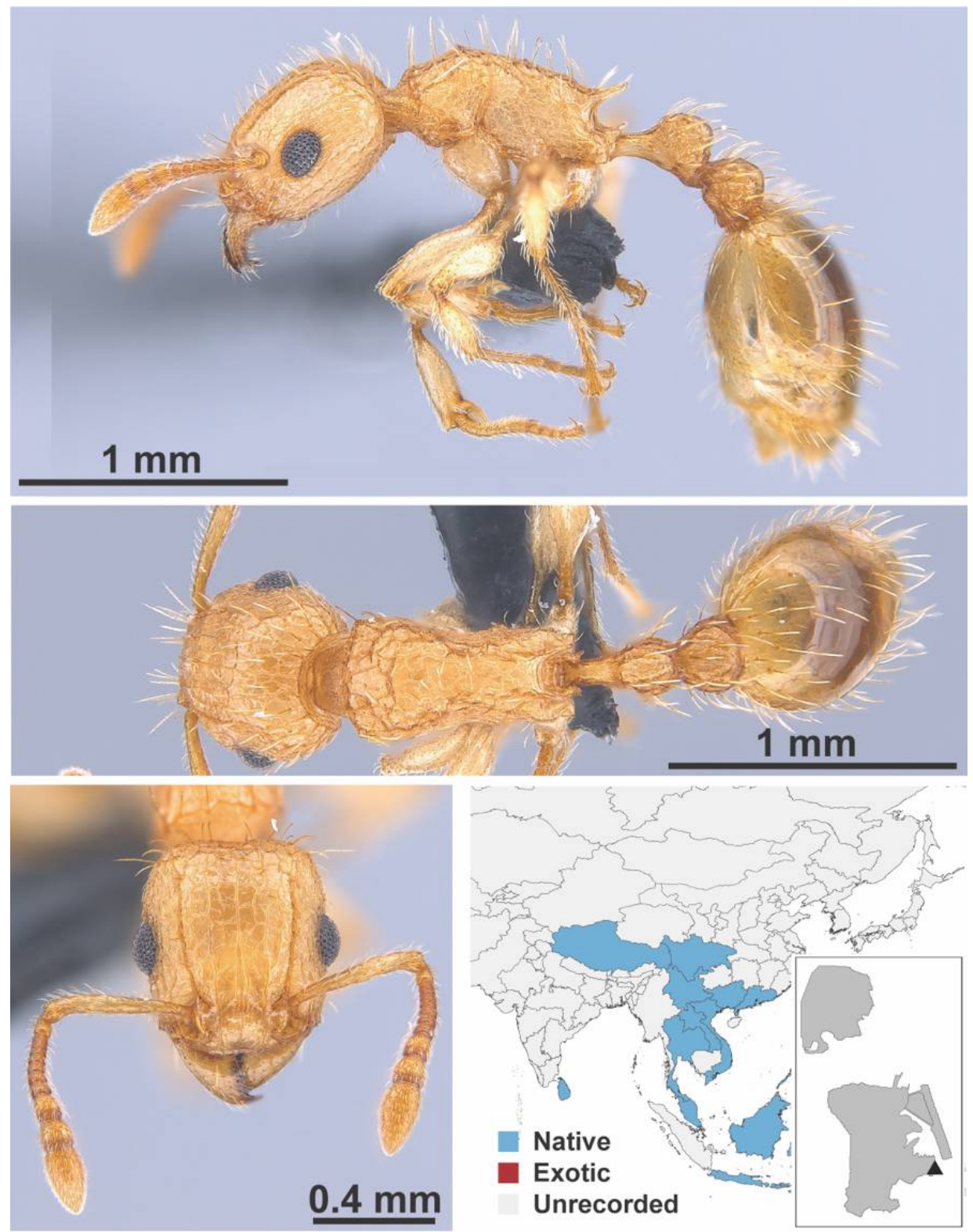

Figure A126. Tetramorium insolens Smith, 1861 worker (MAC_S17_LLSA_Sp.3, IBBL). 

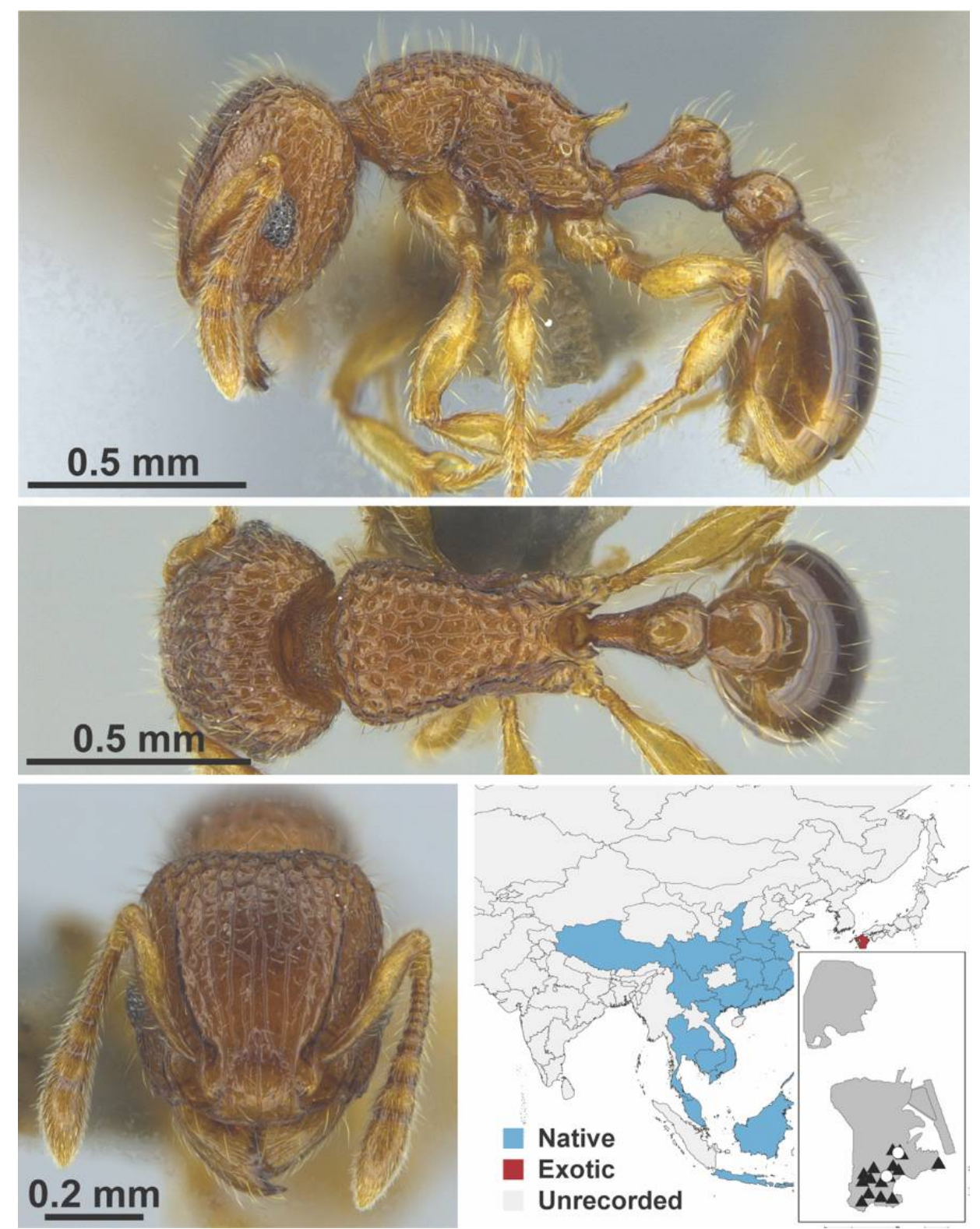

Figure A127. Tetramorium kraepelini Forel, 1905 worker (MAC_S8_GN1_H2_n1_sp.1, IBBL). 


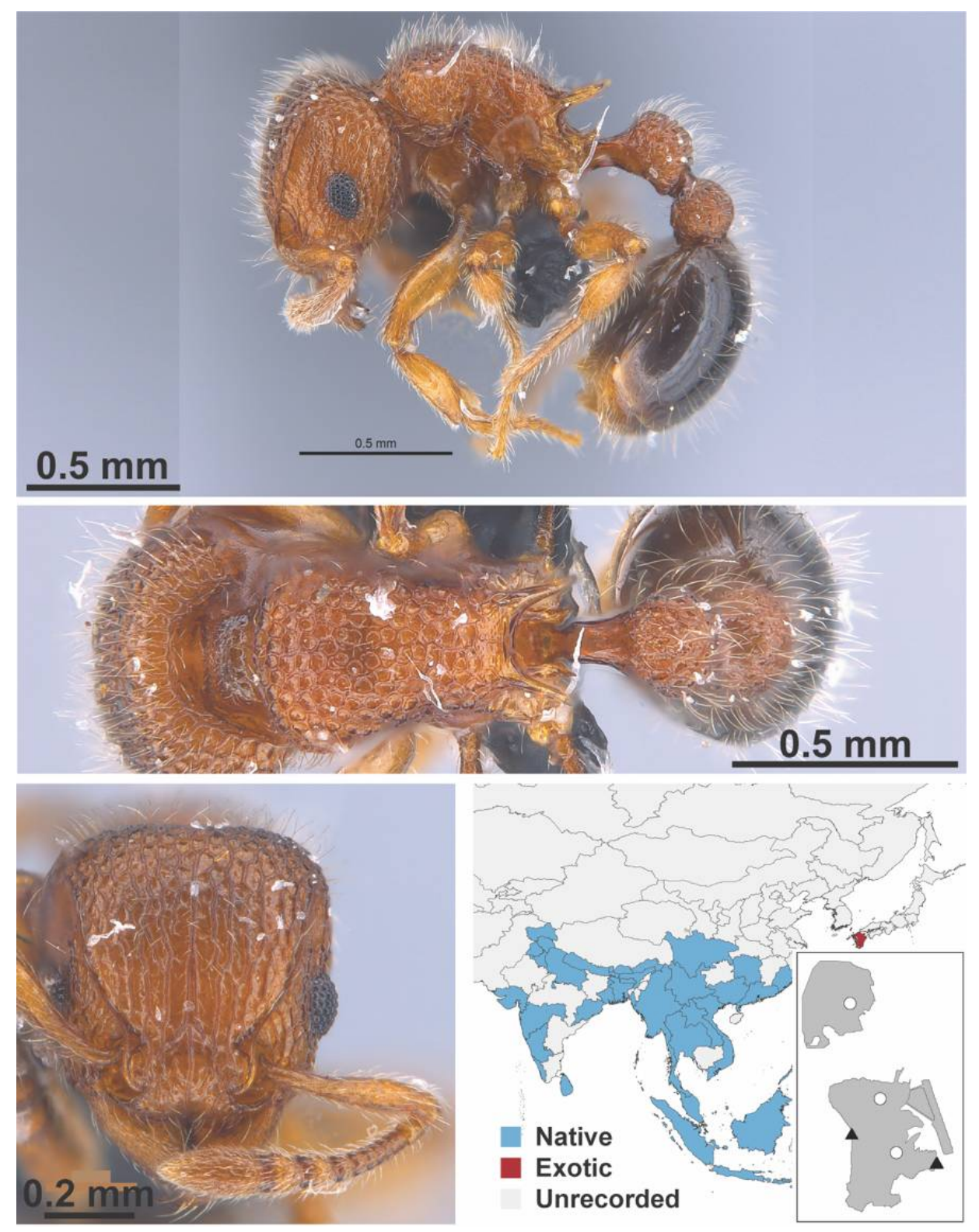

Figure A128. Tetramorium lanuginosum Mayr, 1870 worker (MAC_S17_LLSA_Sp.2, IBBL). 

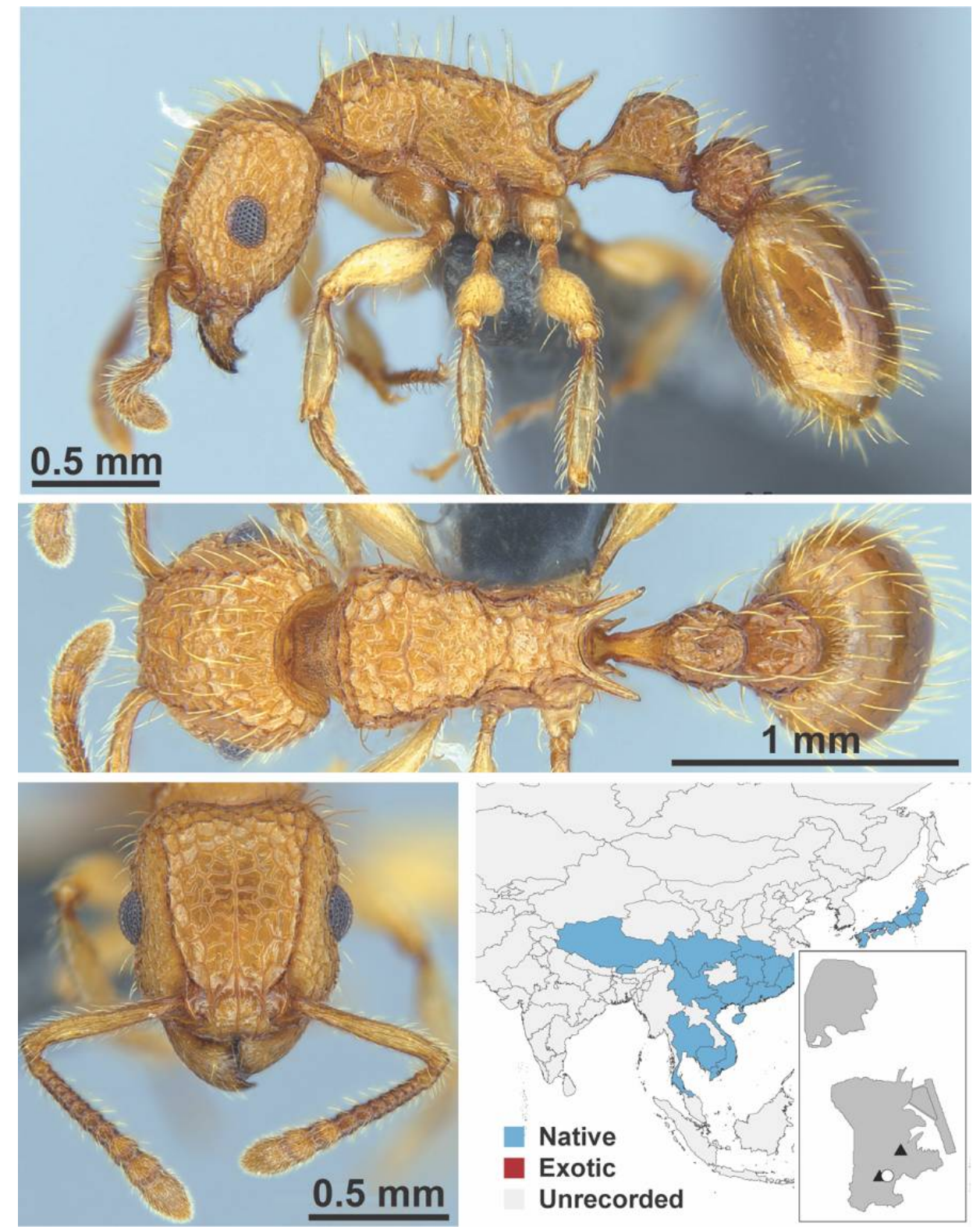

Figure A129. Tetramorium nipponense Wheeler, 1928 worker (MAC_S7_GN2_H4_n1, IBBL). 

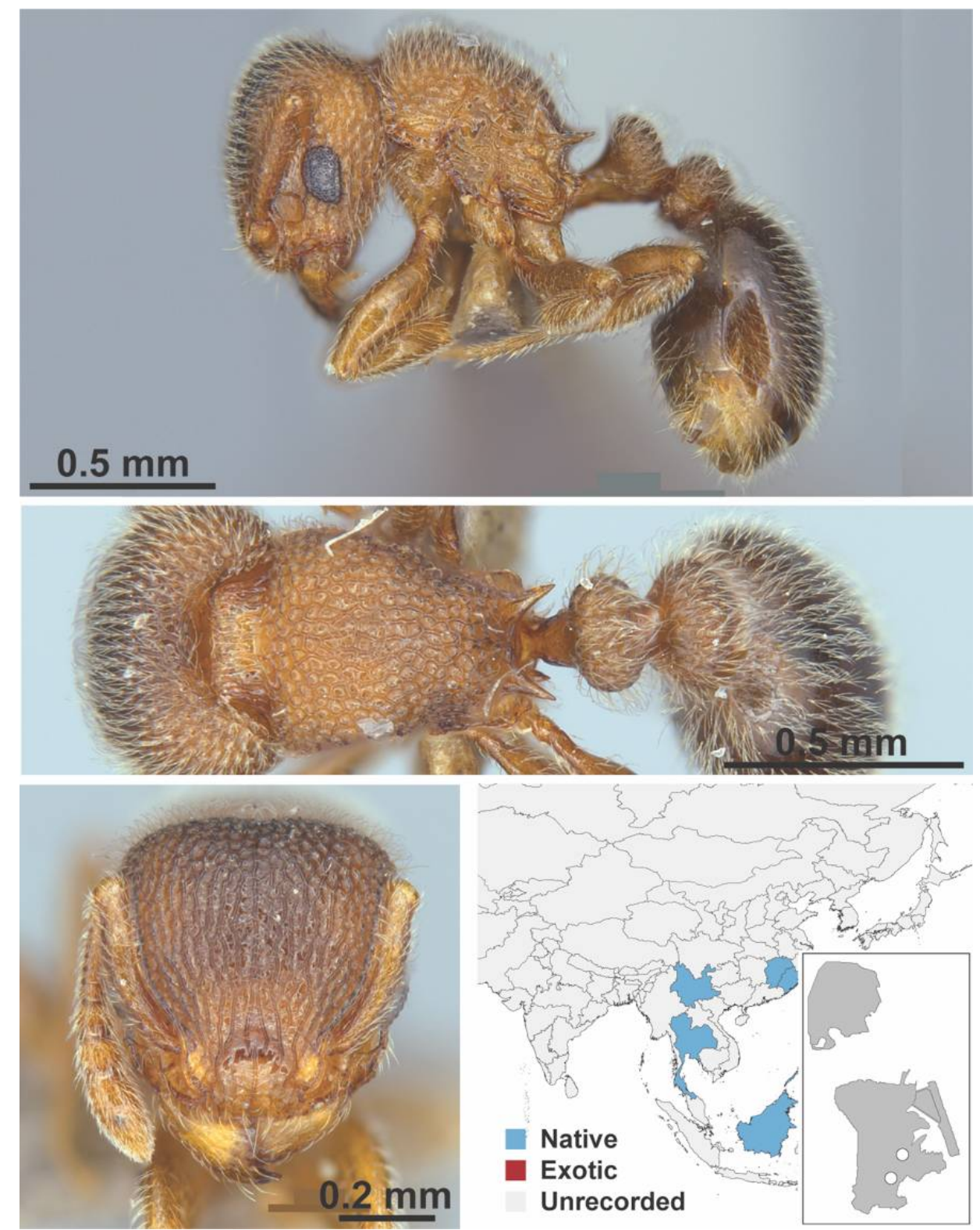

Figure A130. Tetramorium parvispinum Emery, 1893 worker (Tetramorium parvispinum, CML collection). 

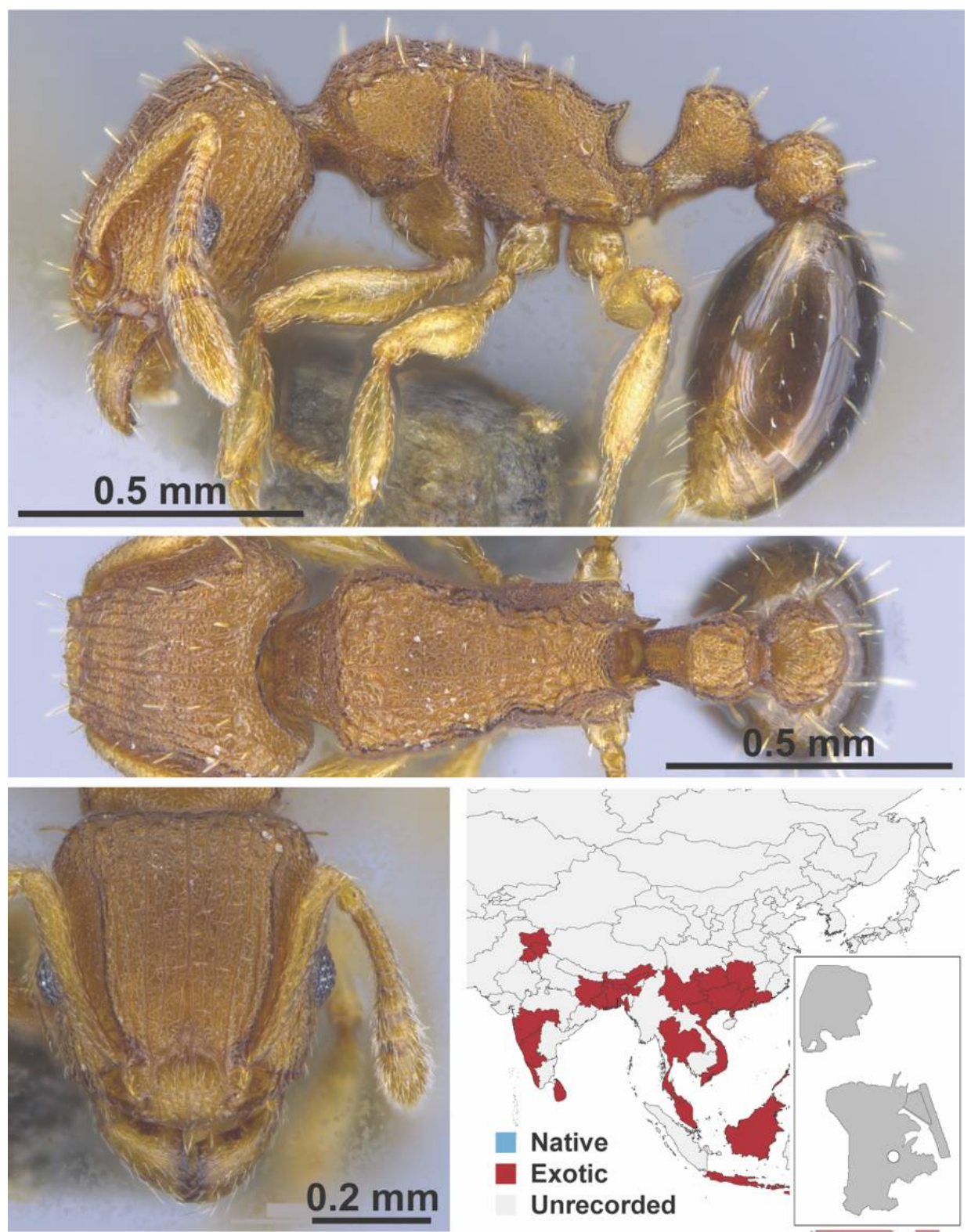

Figure A131. Tetramorium simillinum Smith, 1851 worker (Tetramorium simillinum, IBBL). 

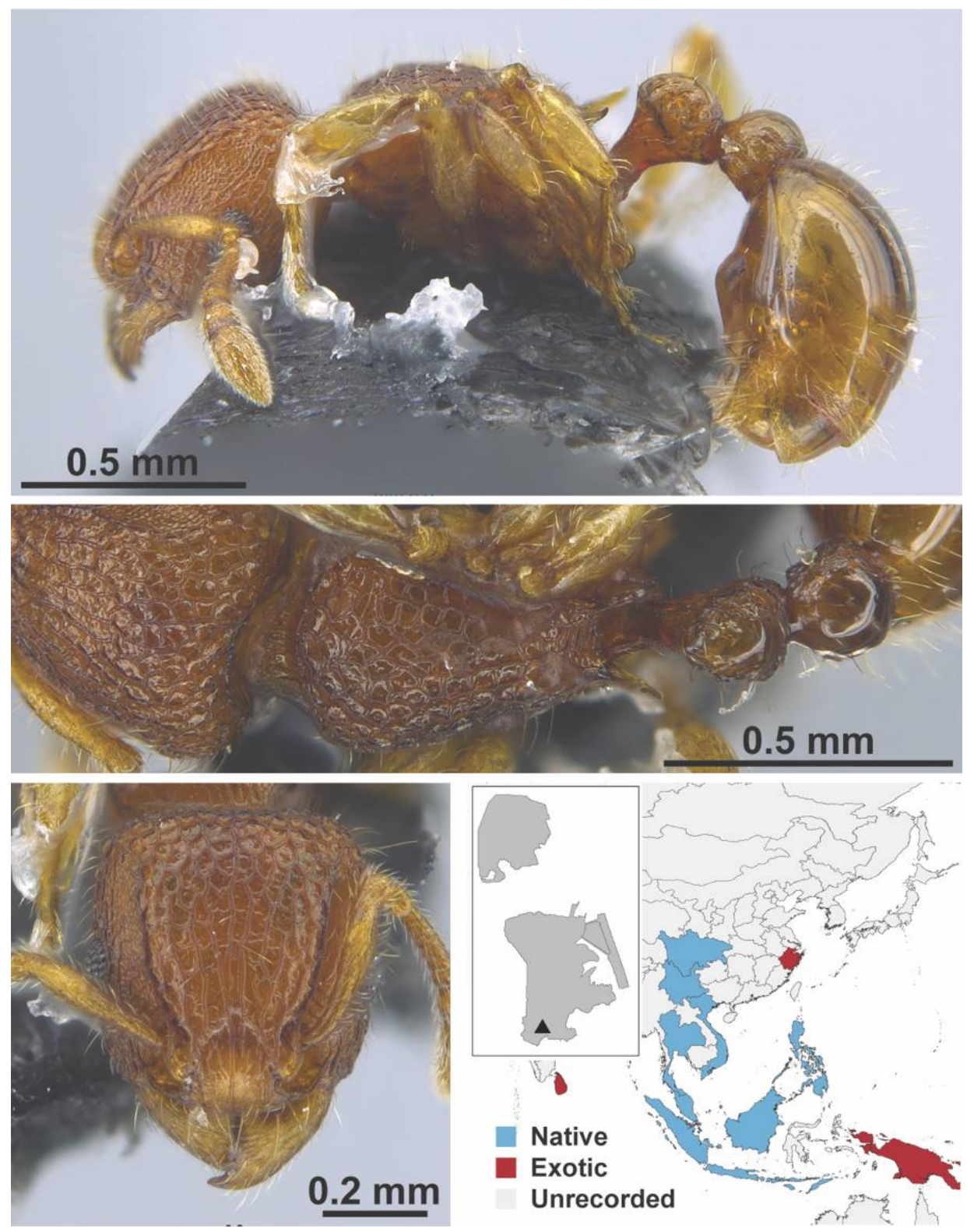

Figure A132. Tetramorium tonganum Mayr, 1870 worker (MAC_S10_T2_1m_sp.2, IBBL). Note that we changed the location of the map of Macao to show the localities where this species has been recorded as an exotic species in Southeast Asia. 

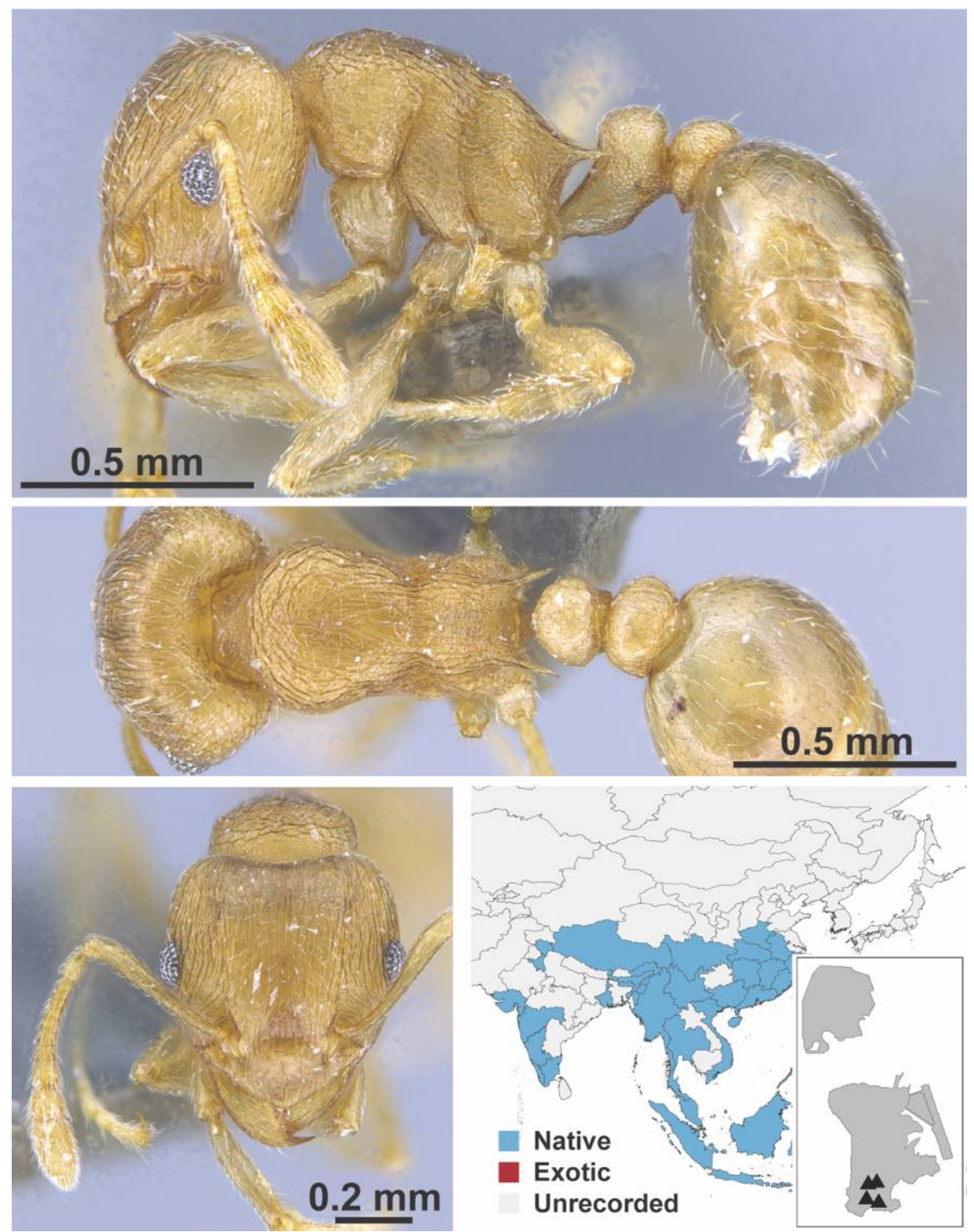

Figure A133. Tetramorium wroughtonii Forel, 1902 worker (MAC_S10_B03_sp.1_top, IBBL). 

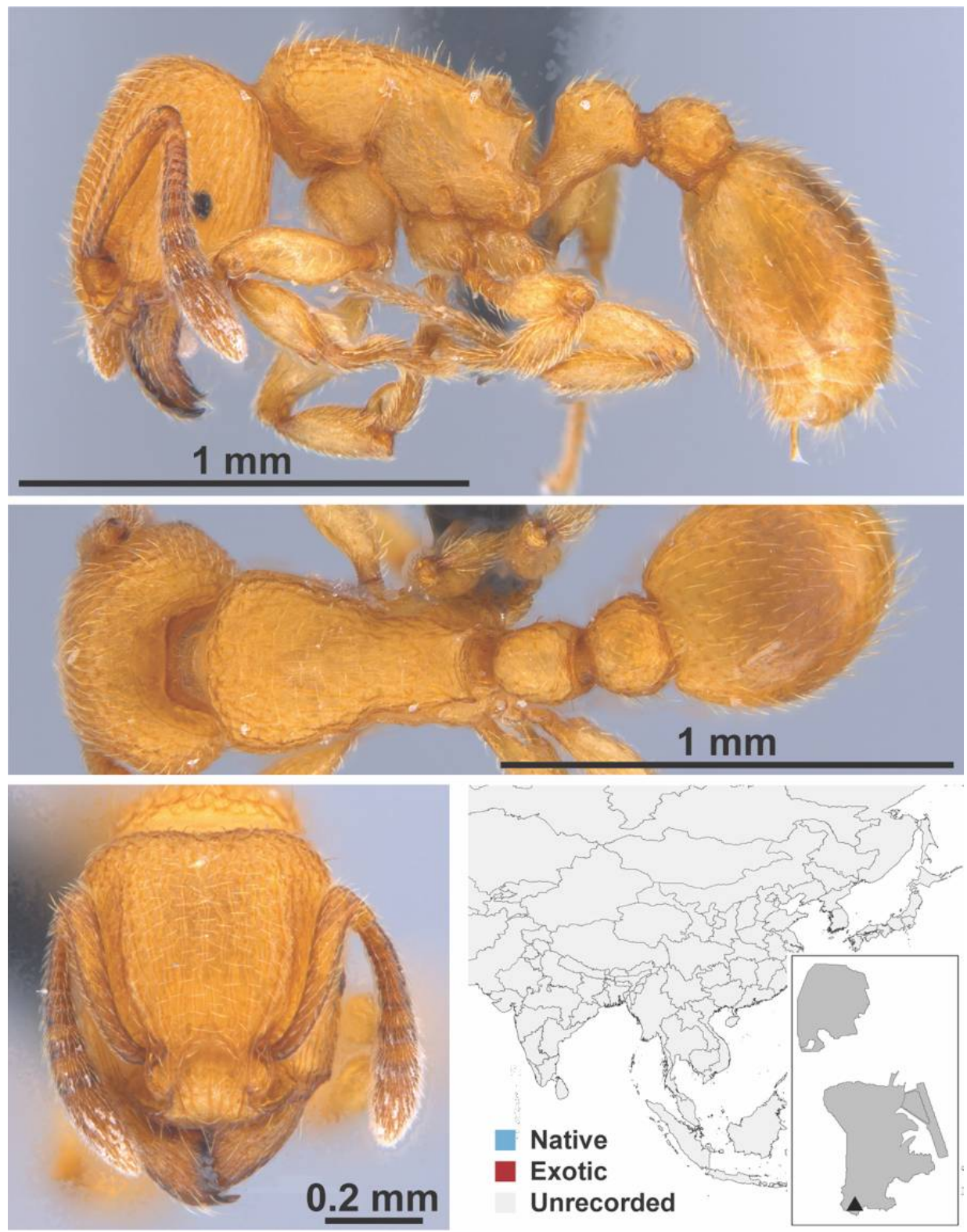

Figure A134. Tetramorium nr. elisabethae Forel, 1904 worker (MAC_S18_q1_25_Sp.2, IBBL). 

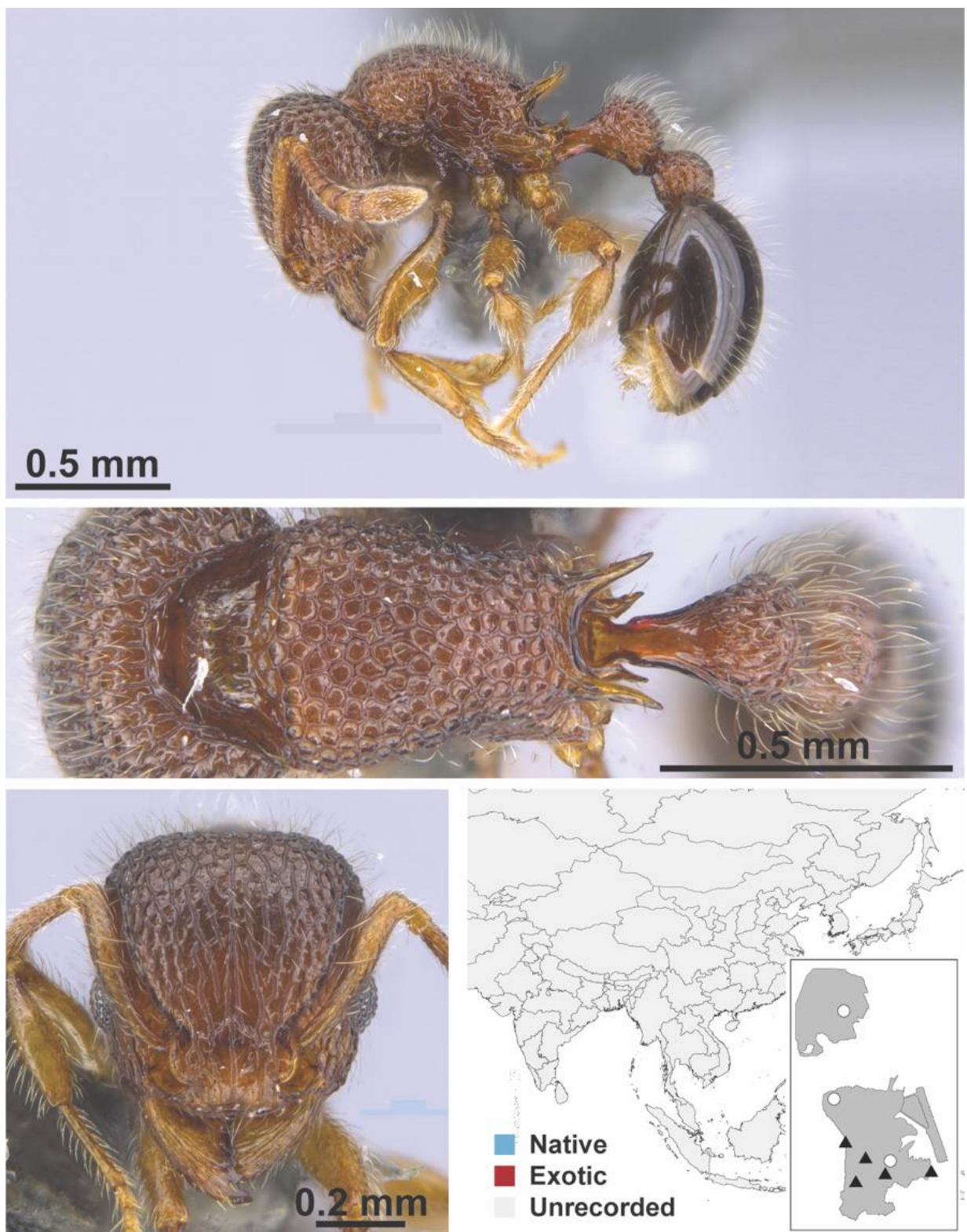

Figure A135. Tetramorium sp. 1 BG (obesum group Bolton, 1976) worker (MAC_S04_LLSP_Sp.3, IBBL). 

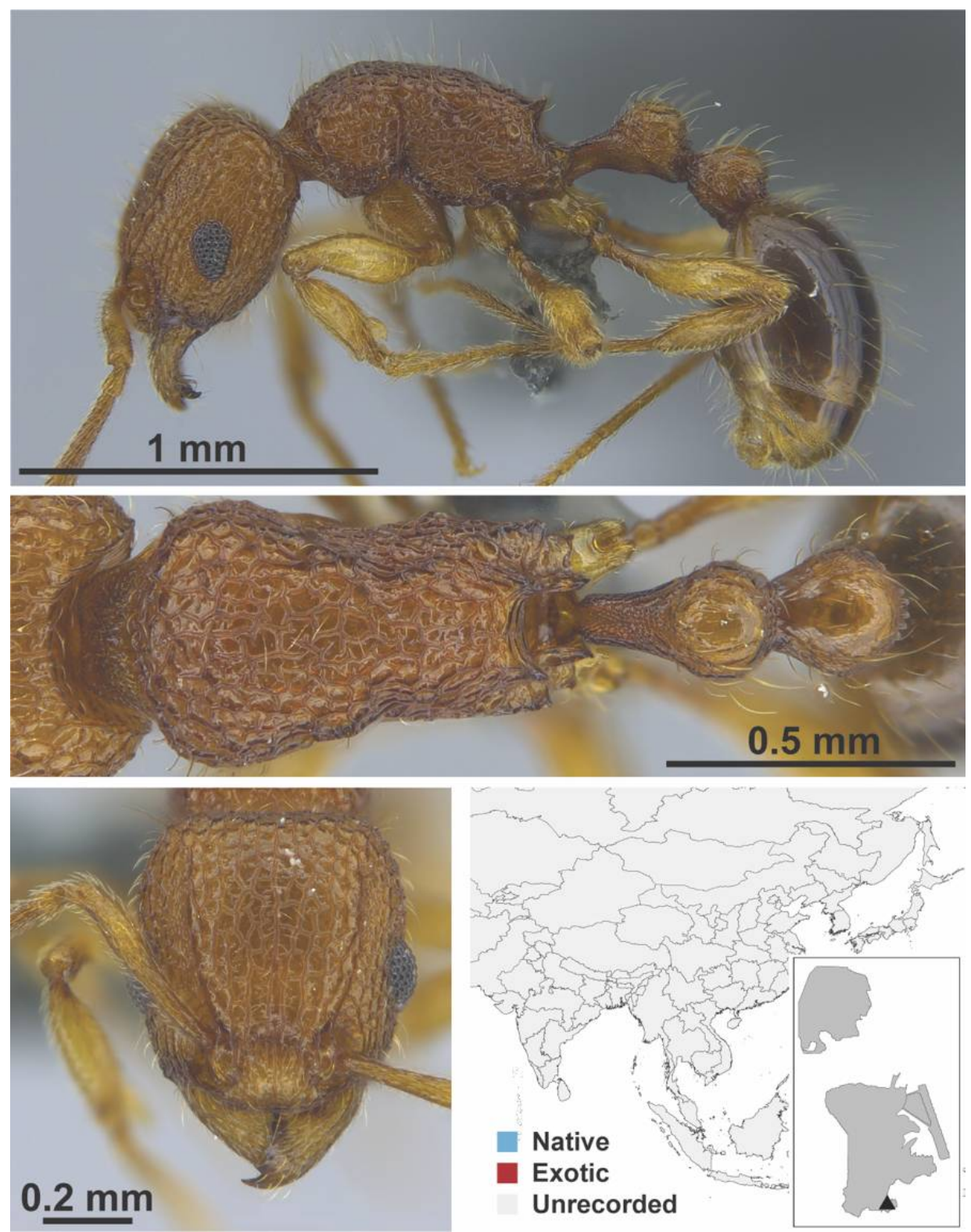

Figure A136. Tetramorium sp. 2 JF worker (MAC_S15_T1_3m_sp.2, IBBL). 

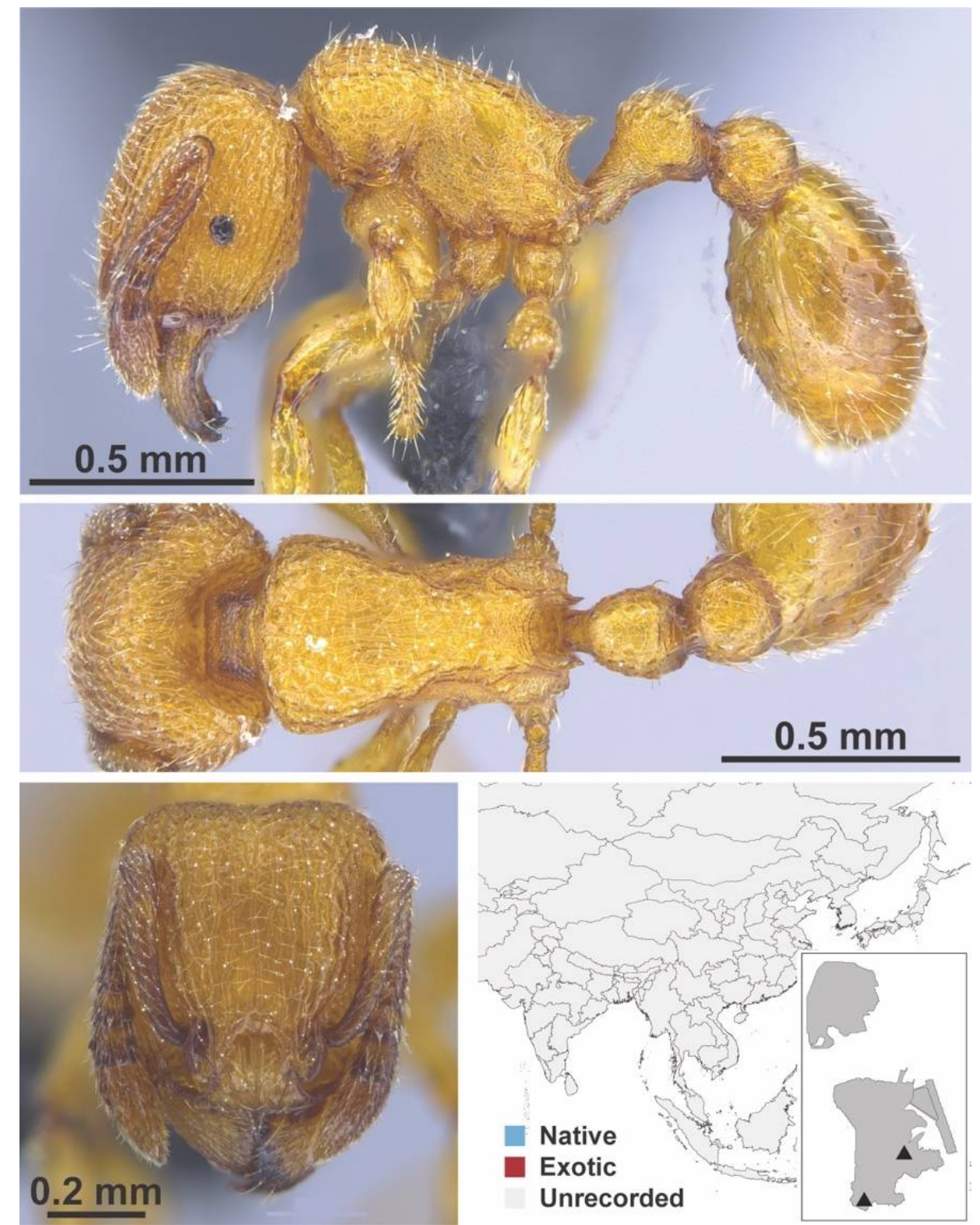

Figure A137. Tetramorium sp. 9 JF worker (MAC_S18_q2_25_sp.1, IBBL). 

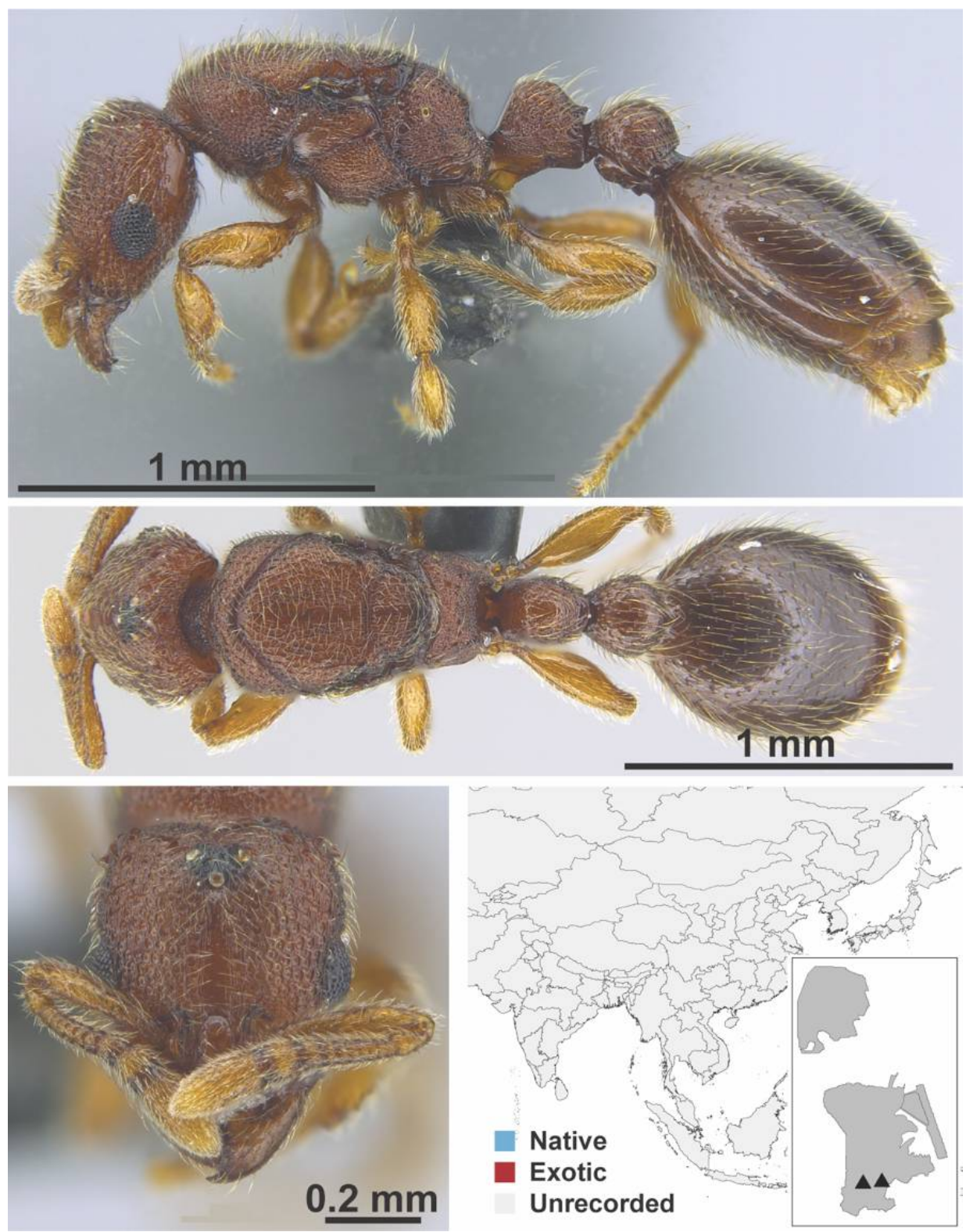

Figure A138. Vollenhovia sp. 1 BG queen (MAC_S06_GN3_H3_n1, IBBL). 

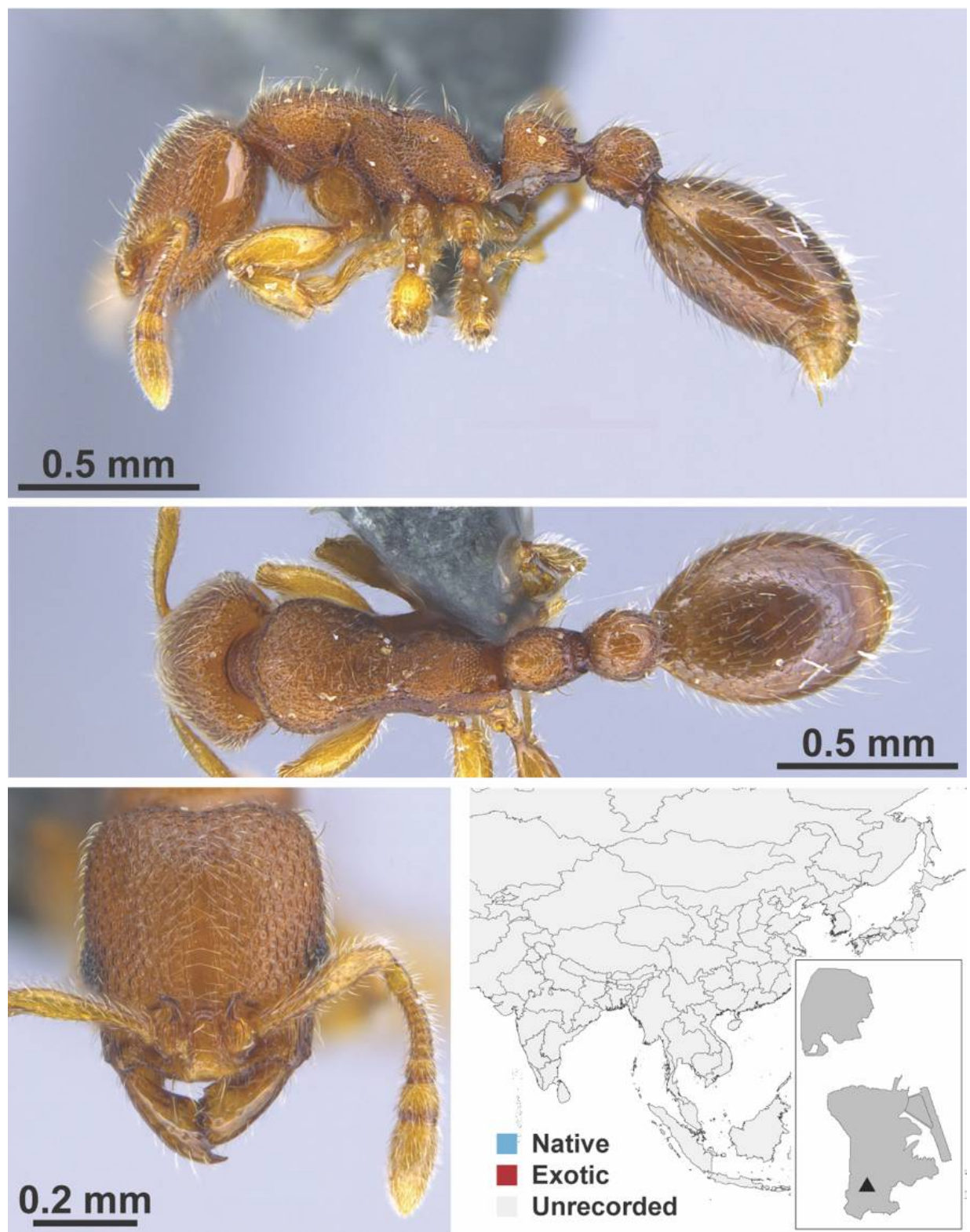

Figure A139. Vollenhovia sp. 2 BG worker (MAC_S02_LLSP_Sp.5, IBBL). 
Appendix A.7 PONERINAE

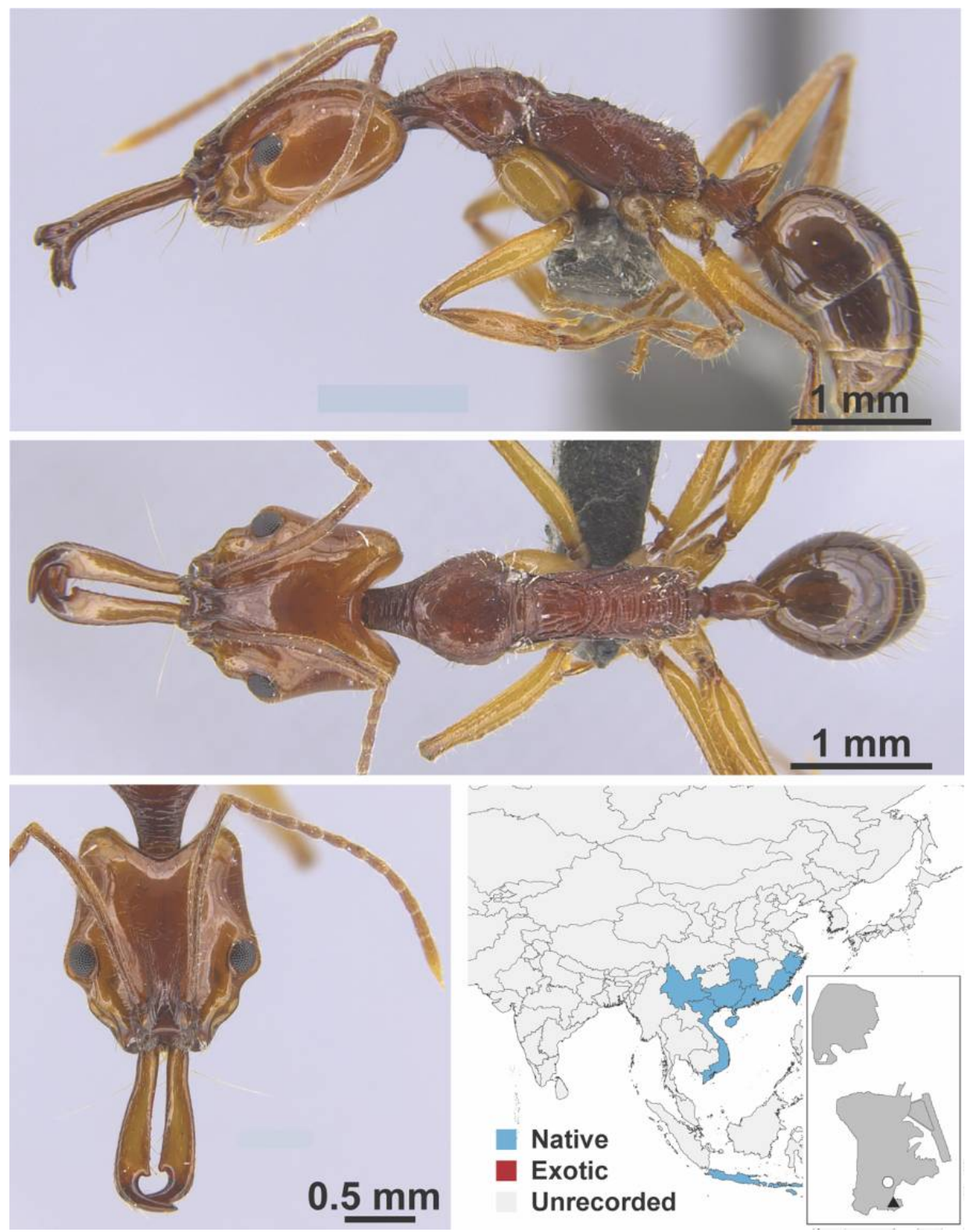

Figure A140. Anochetus risii Forel, 1900 worker (MAC_FB19180, IBBL). 


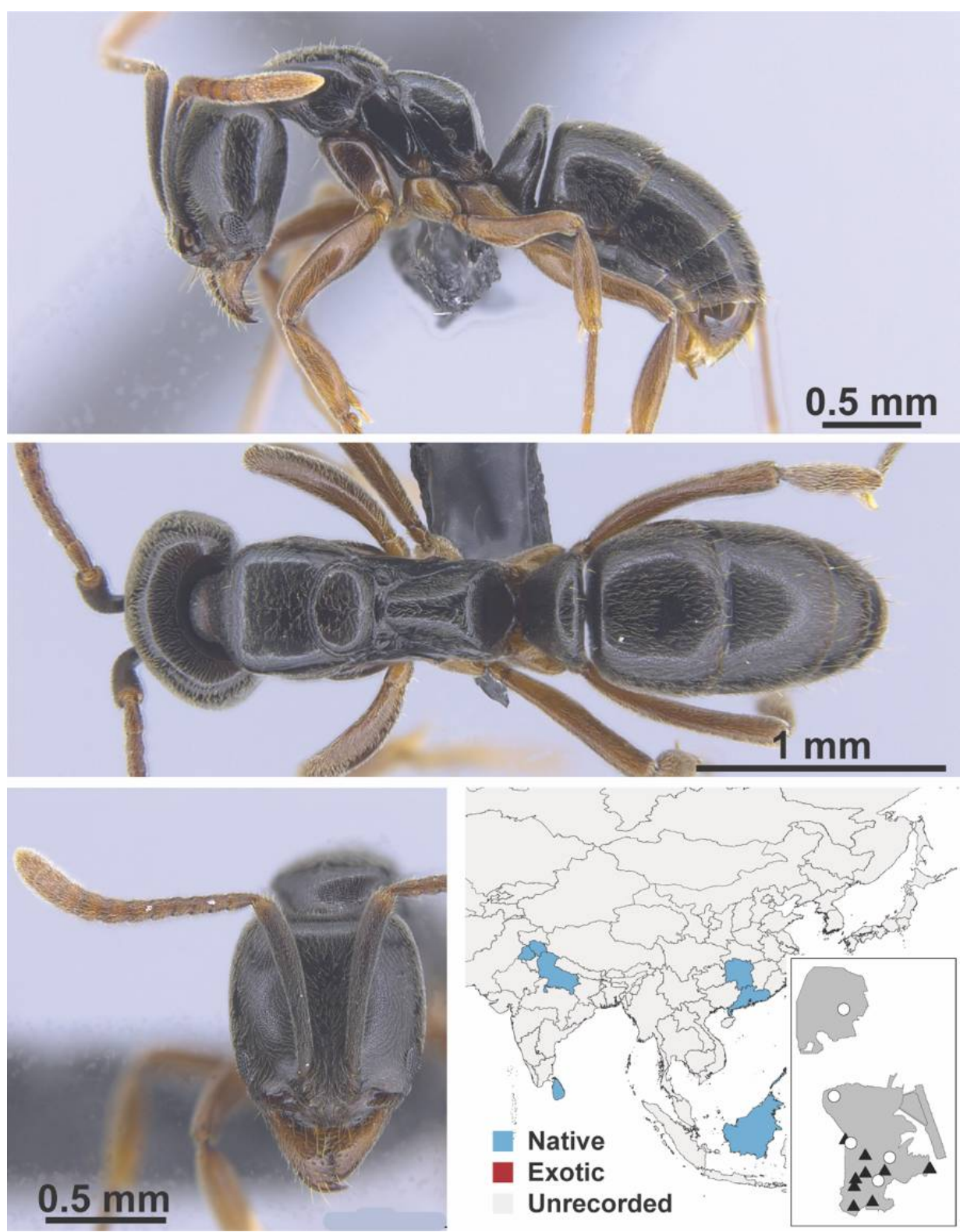

Figure A141. Brachyponera obscurans Mayr, 1862 worker (MAC_S19_LLSA, IBBL). 


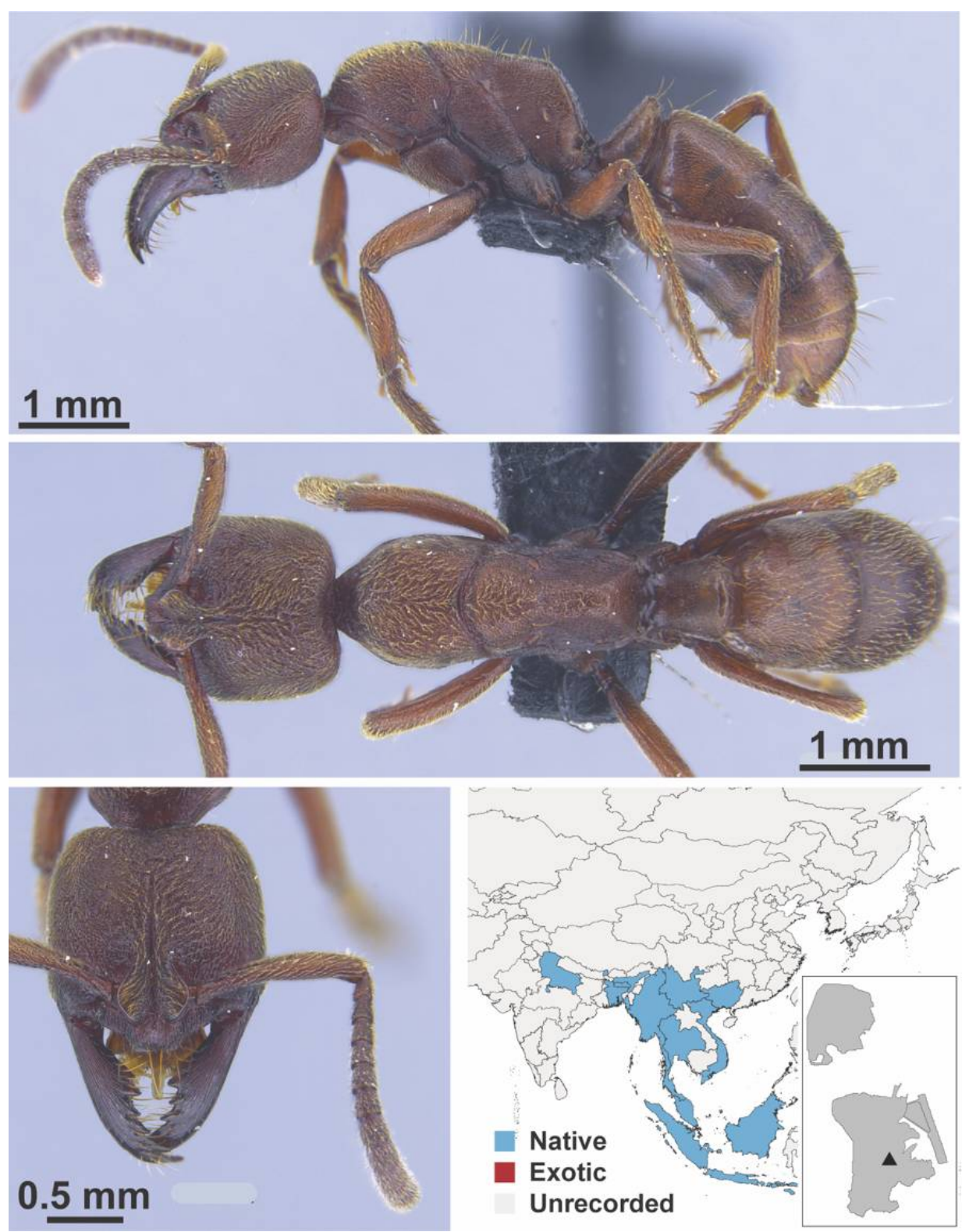

Figure A142. Buniapone amblyops Emery, 1887 worker (MAC_S12_q4_50_sp.2_top, IBBL). 

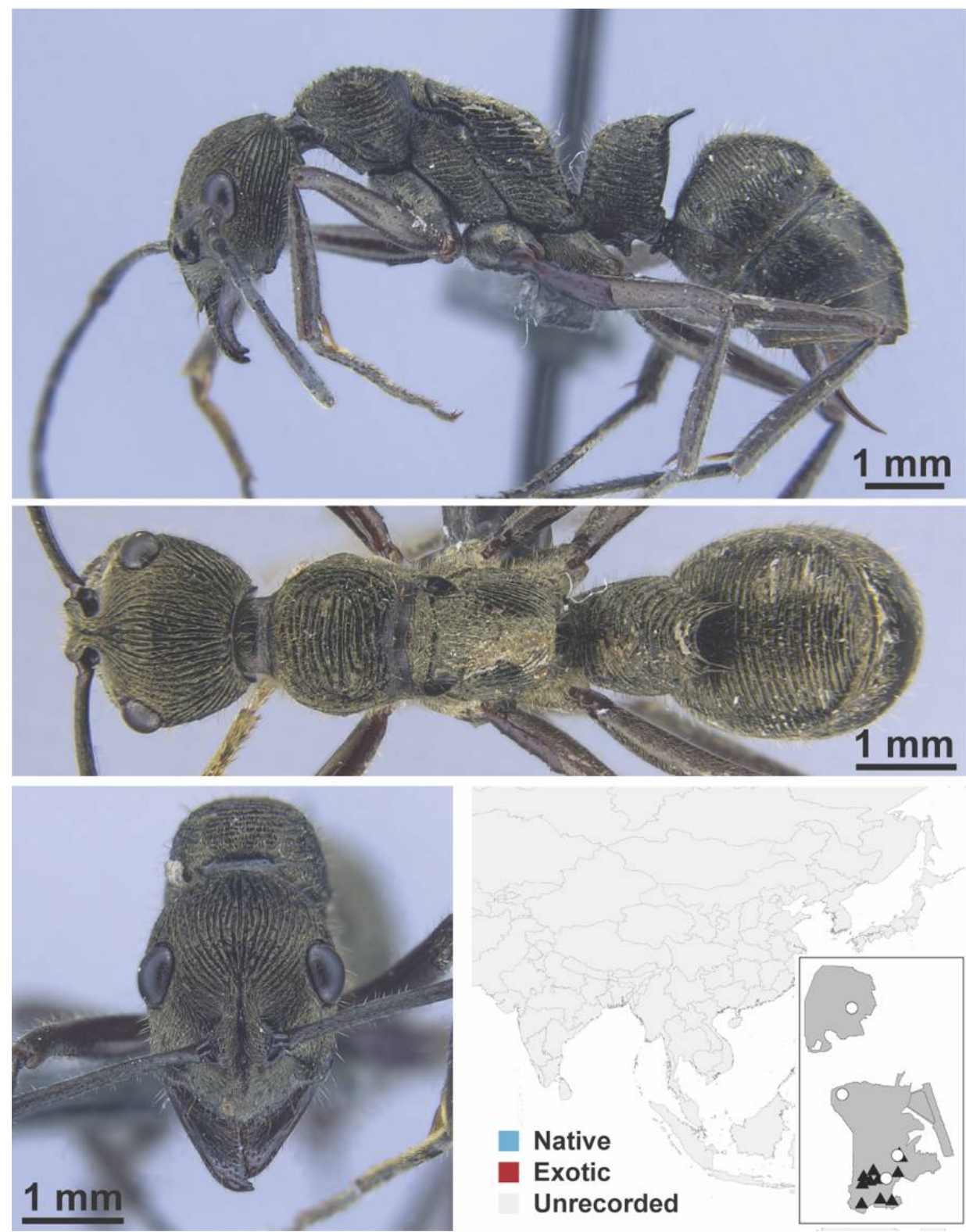

Figure A143. Diacamma sp. 1 worker (MAC_S15_LLSA_sp.1, IBBL). 


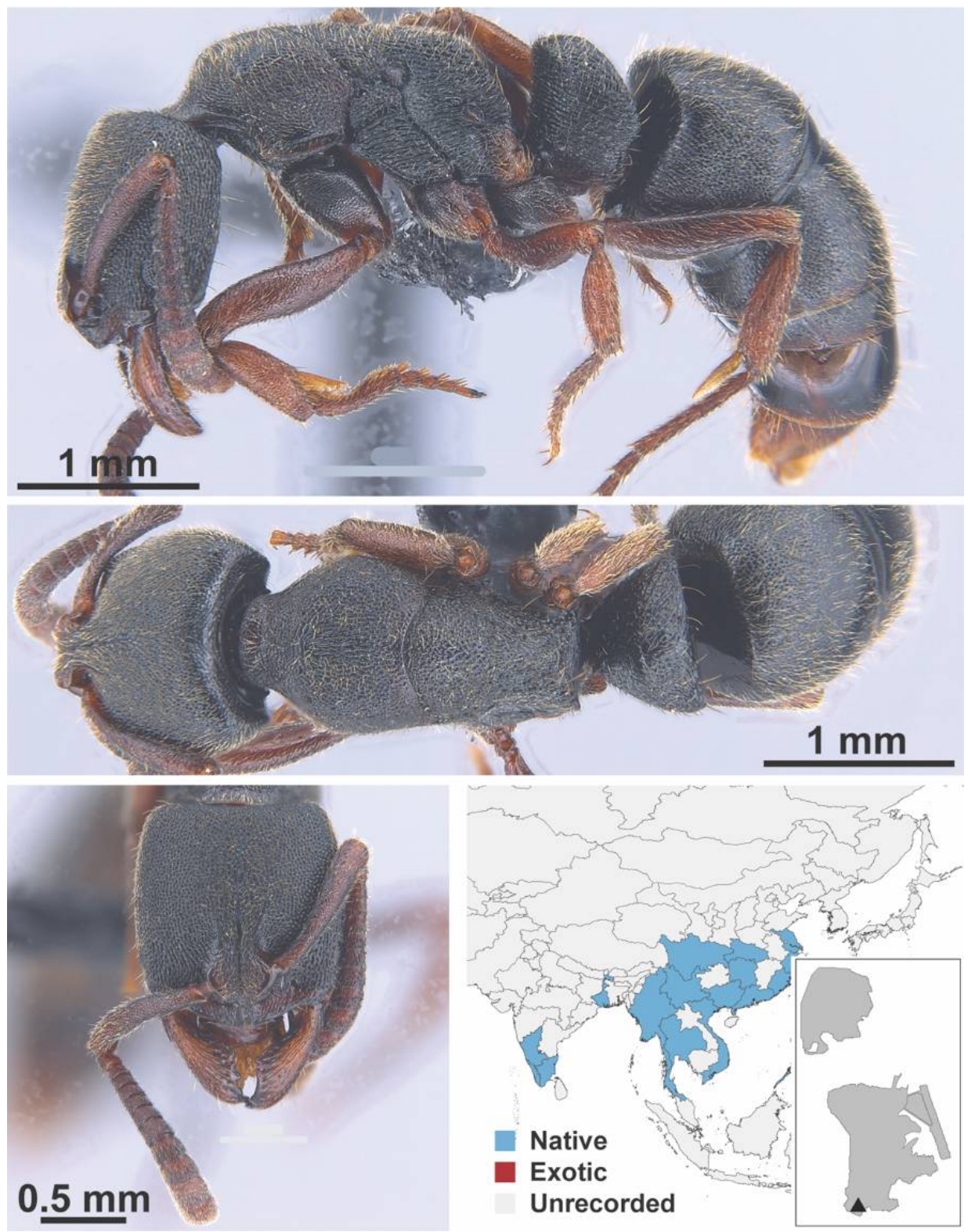

Figure A144. Ectomomyrmex annamitus André, 1892 worker (MAC_S18_q2_37.5_Sp.4, IBBL). 


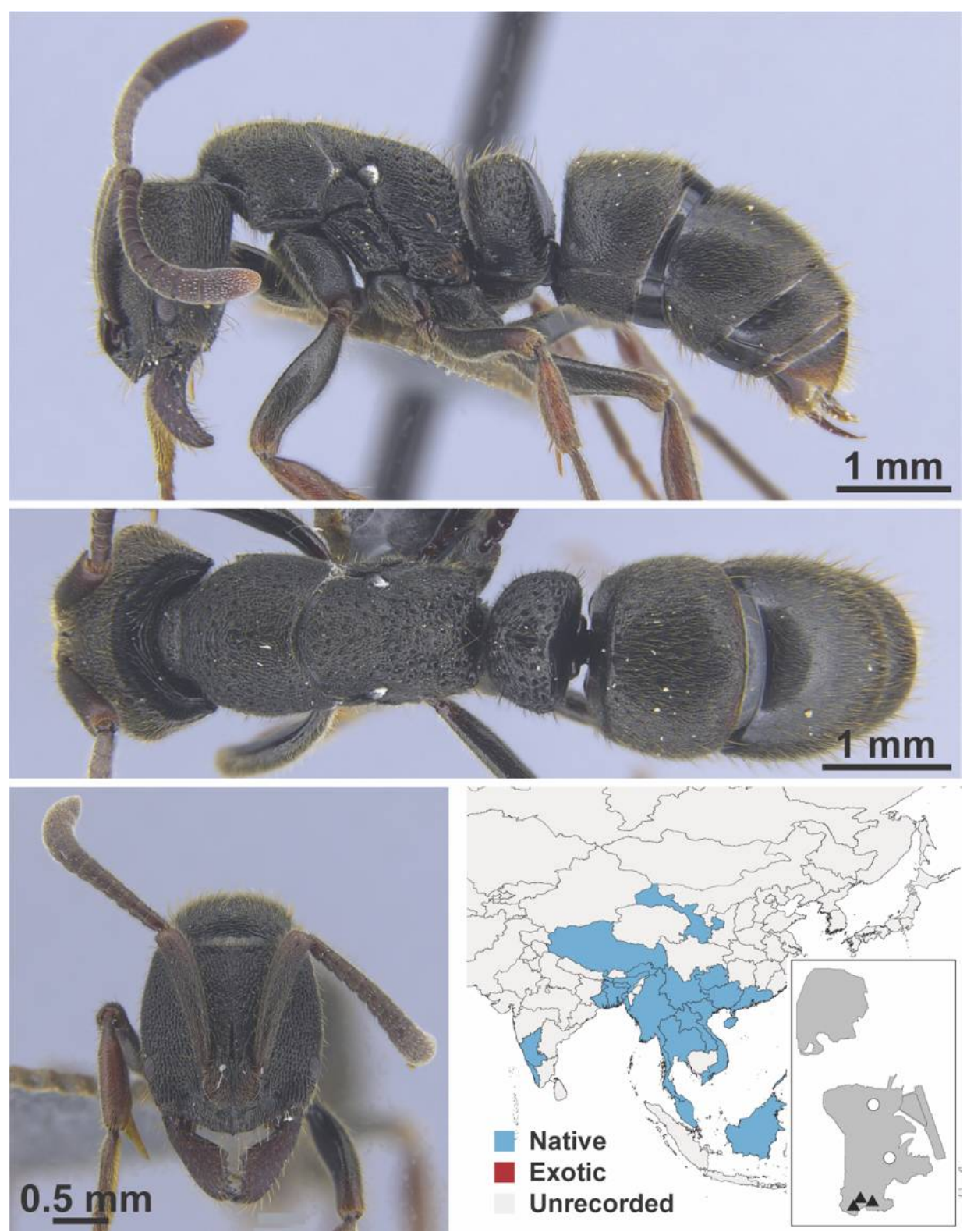

Figure A145. Ectomomyrmex leeuwenhoecki Forel, 1886 worker (MAC_S18_GN5_H4_n1, IBBL). 


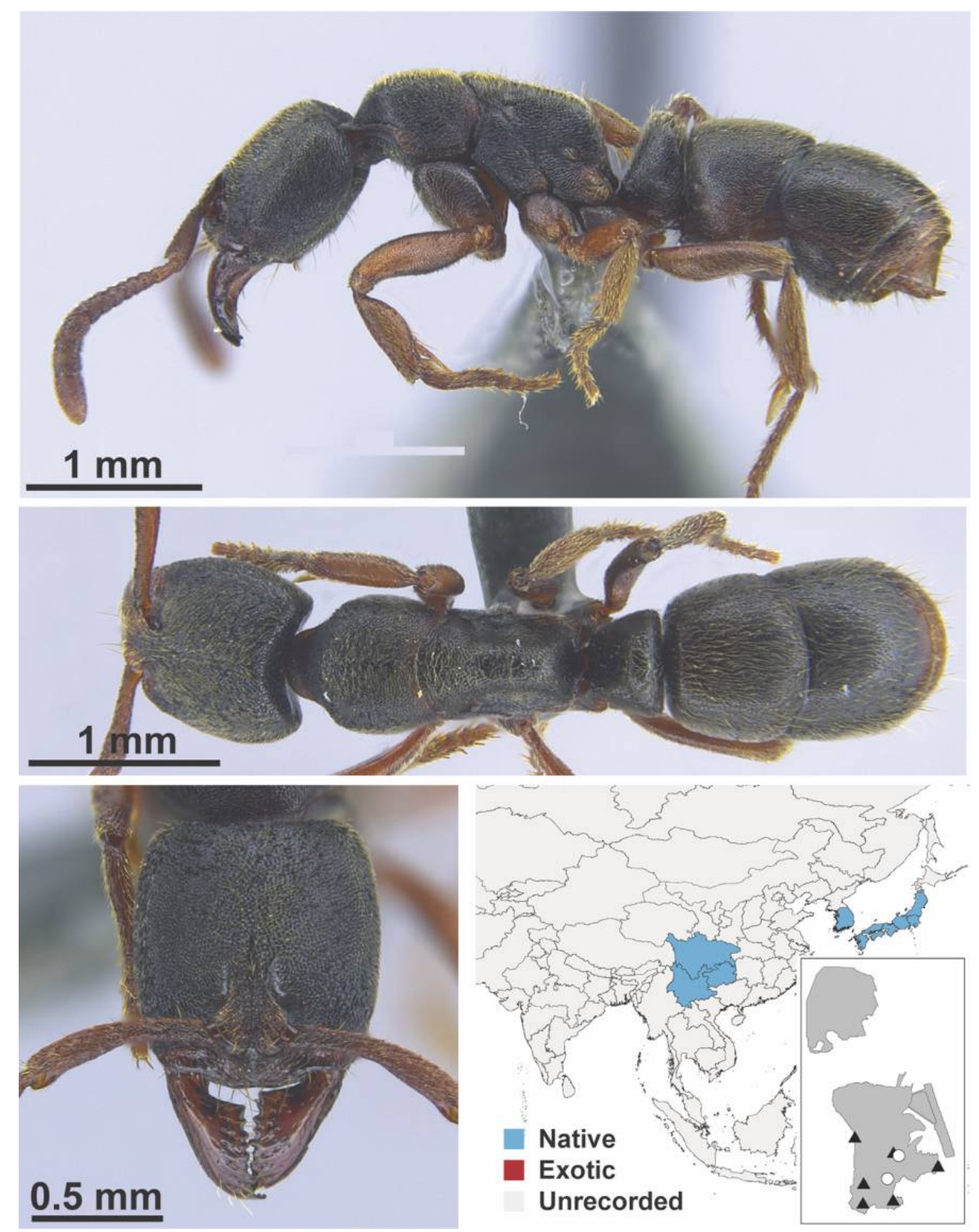

Figure A146. Euponera pilosior Wheeler, 1928 worker (MAC_S12_q3_50_Sp.1, IBBL). 


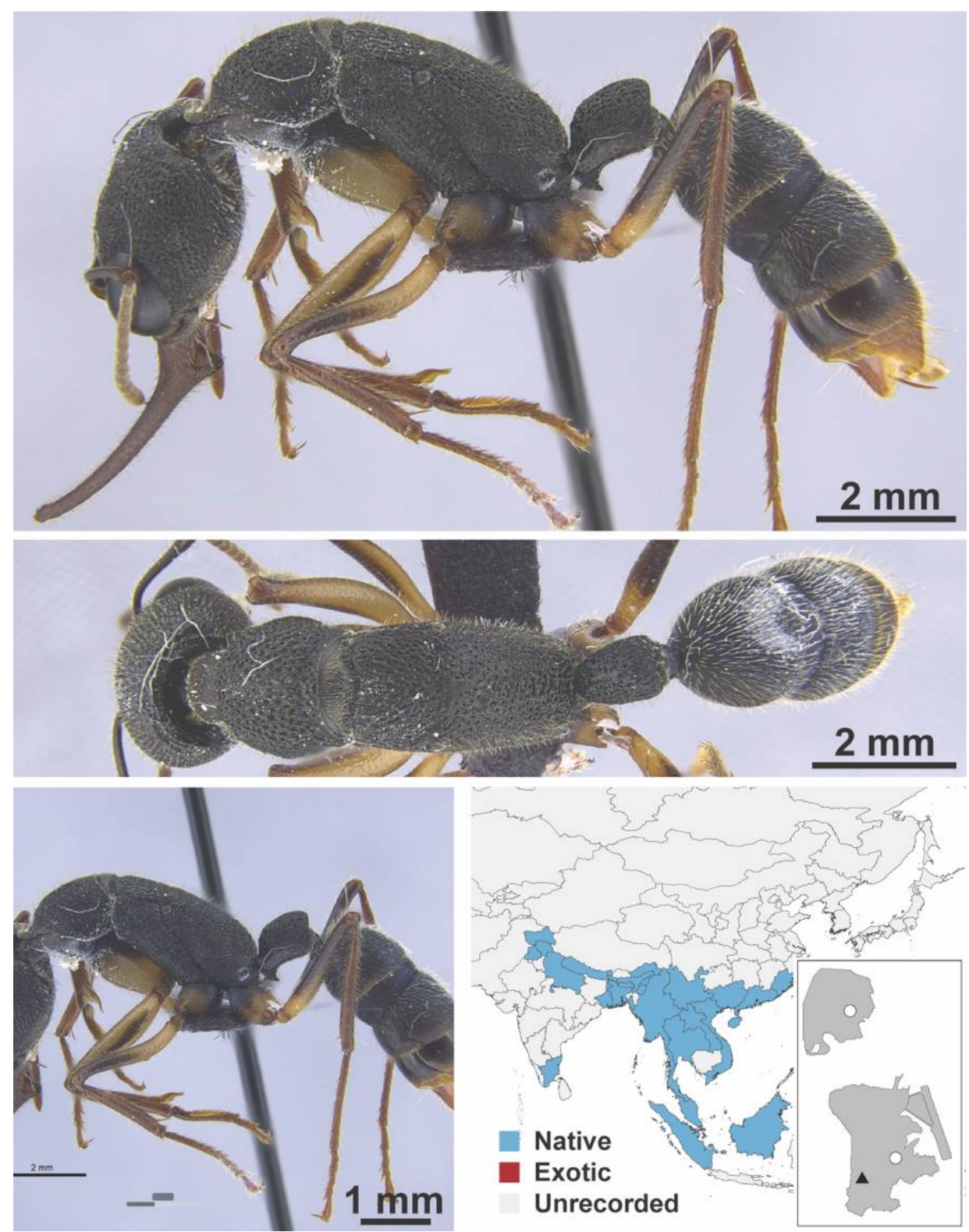

Figure A147. Harpegnathos venator Smith, 1858 worker (MAC_ZOO_HC07_Sp.1, IBBL). 

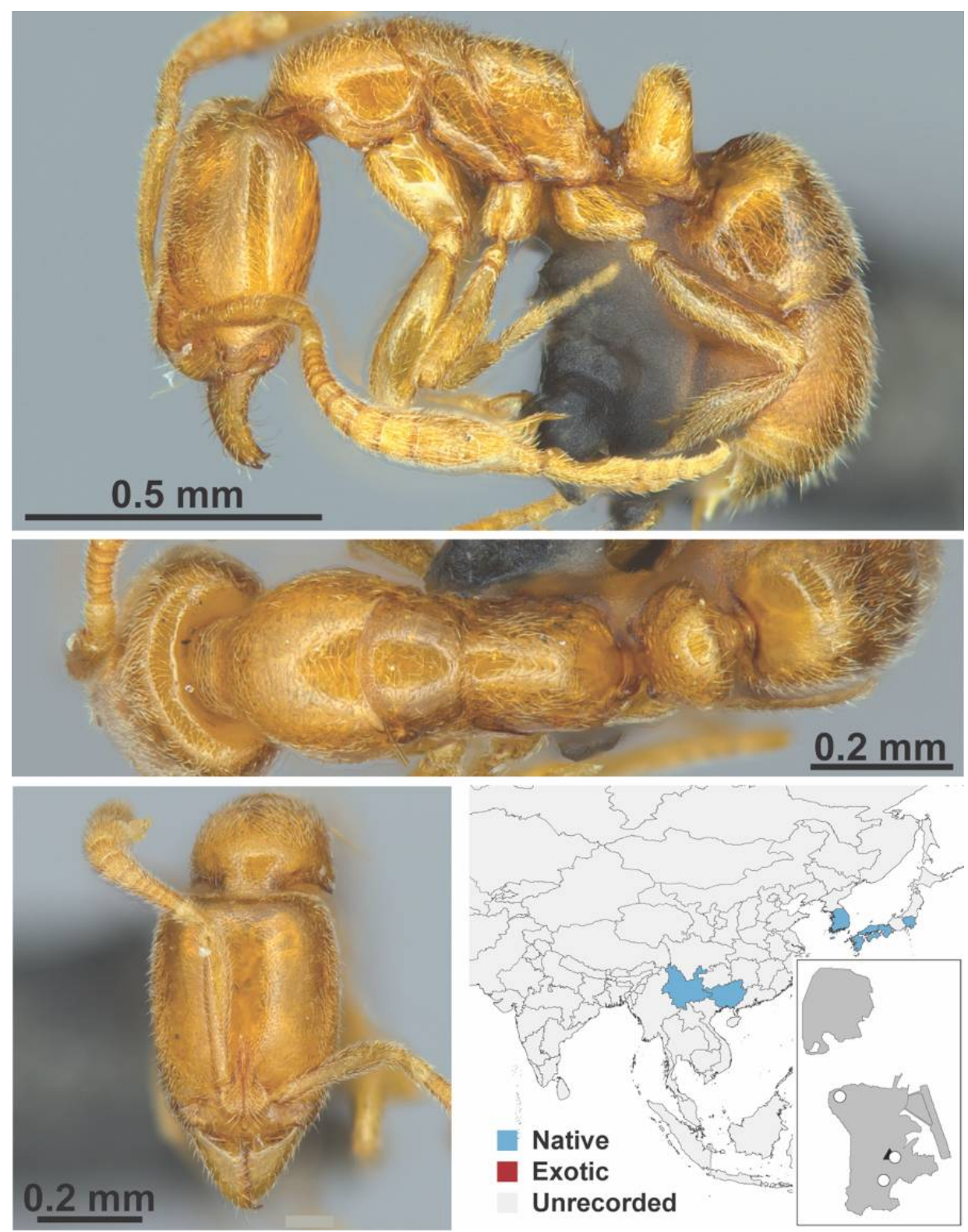

Figure A148. Hypoponera exoecata Wheeler, 1928 worker (Hypoponera exoecata, CML collection). 

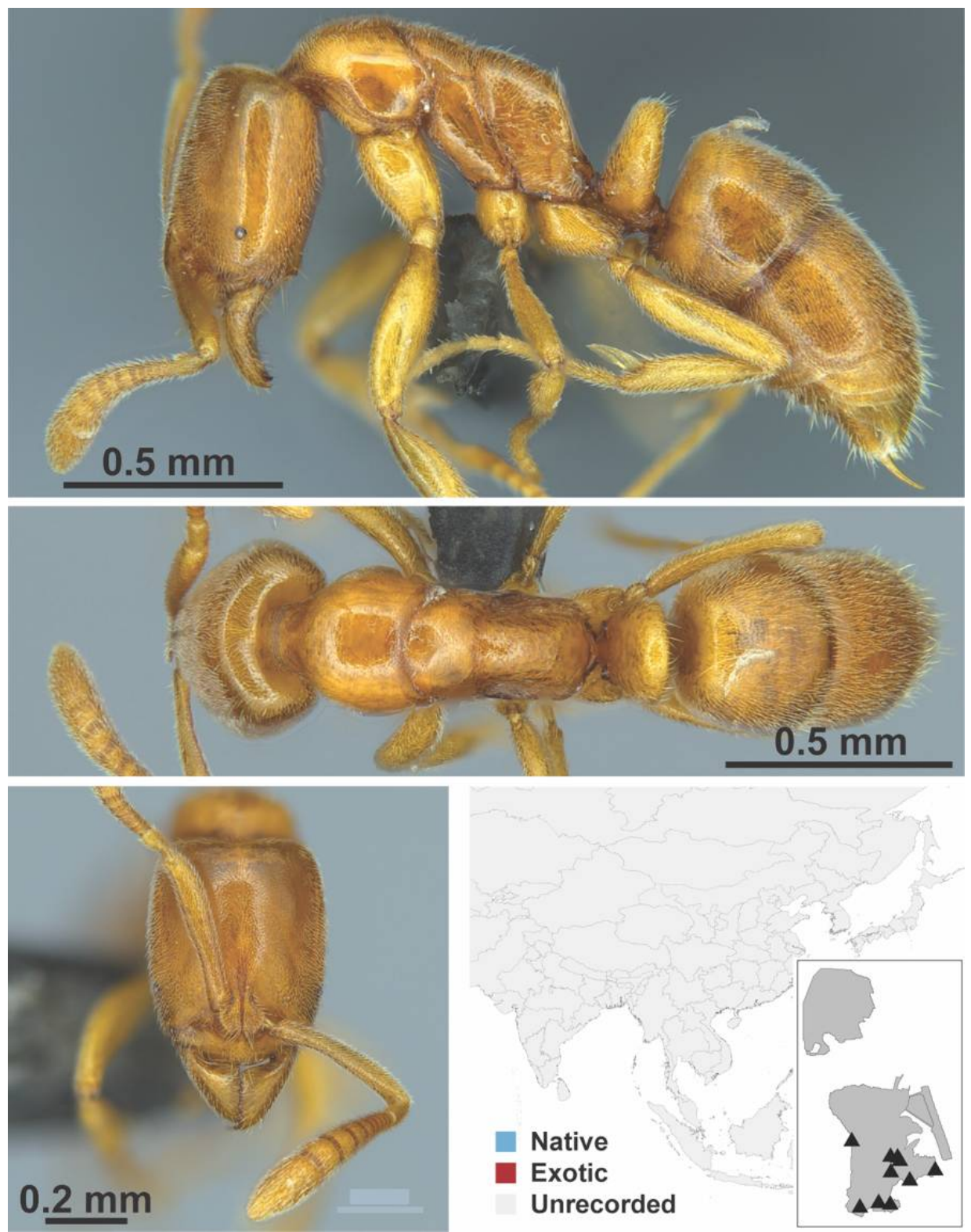

Figure A149. Hypoponera sp. psw-cn01 worker (Hypoponera sp. psw-cn01, CML collection). 


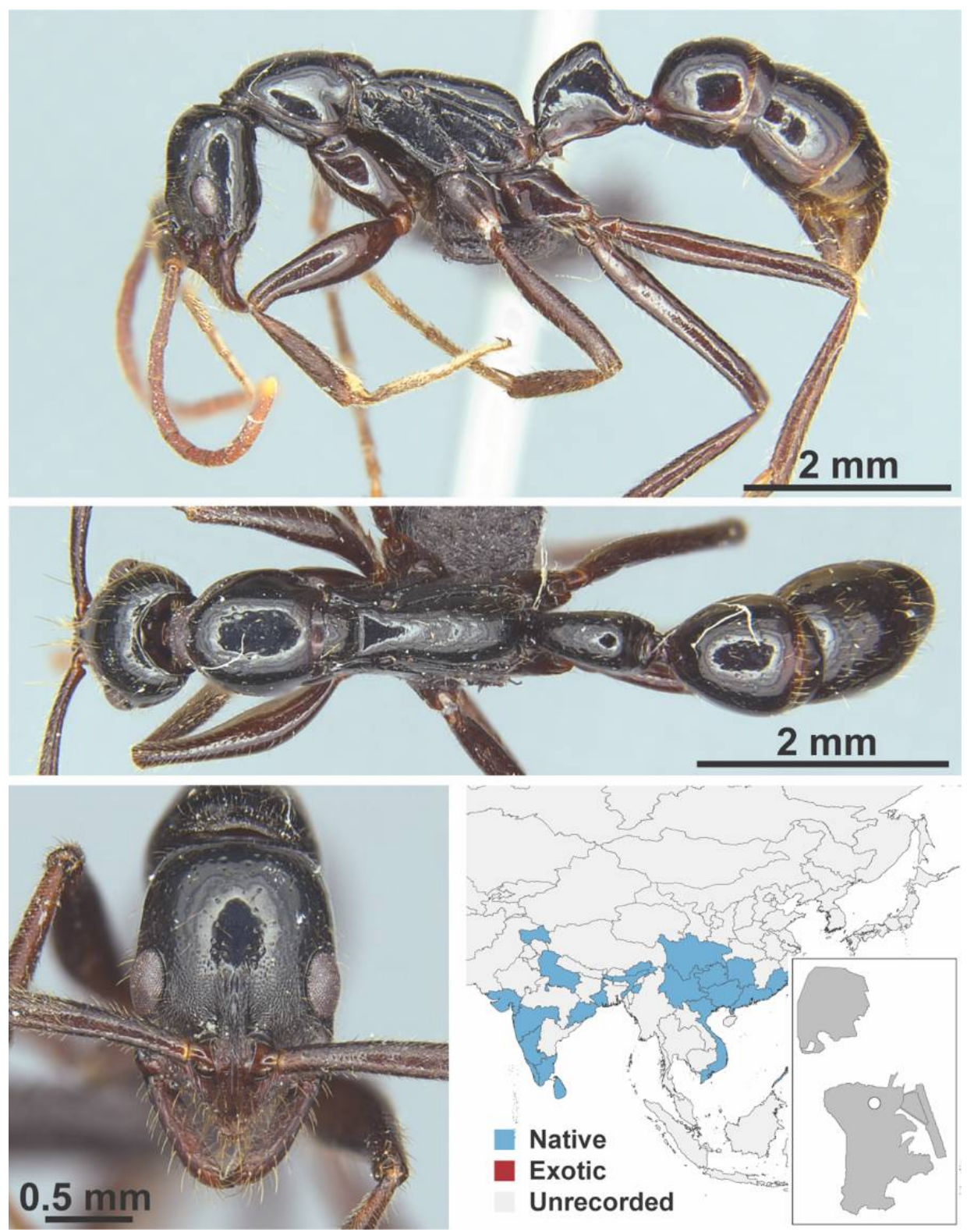

Figure A150. Leptogenys chinensis Mayr, 1870 worker (RHL00861, IBBL). 


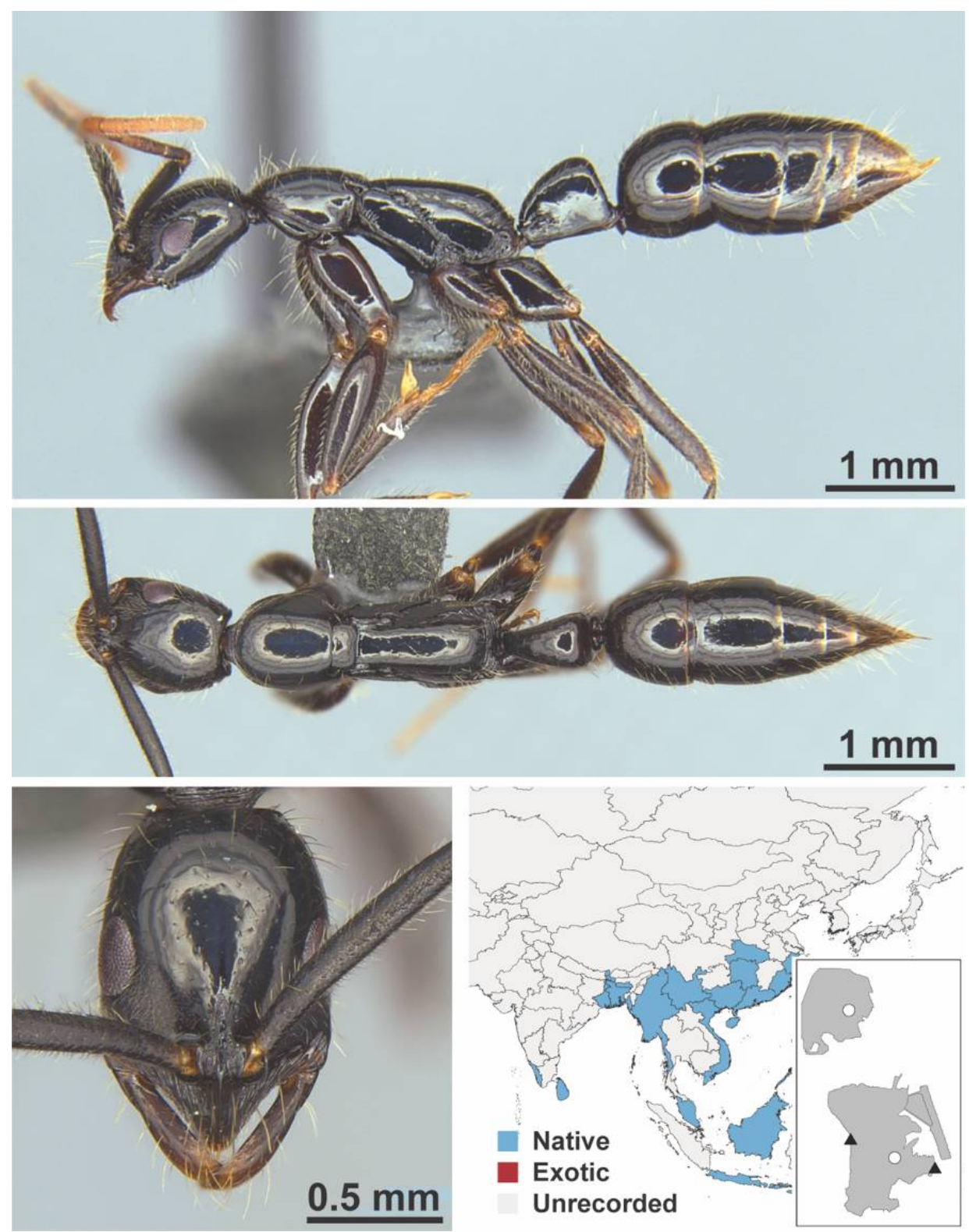

Figure A151. Leptogenys peuqueti André, 1887 worker (Leptogenys peuqueti, CML collection). 


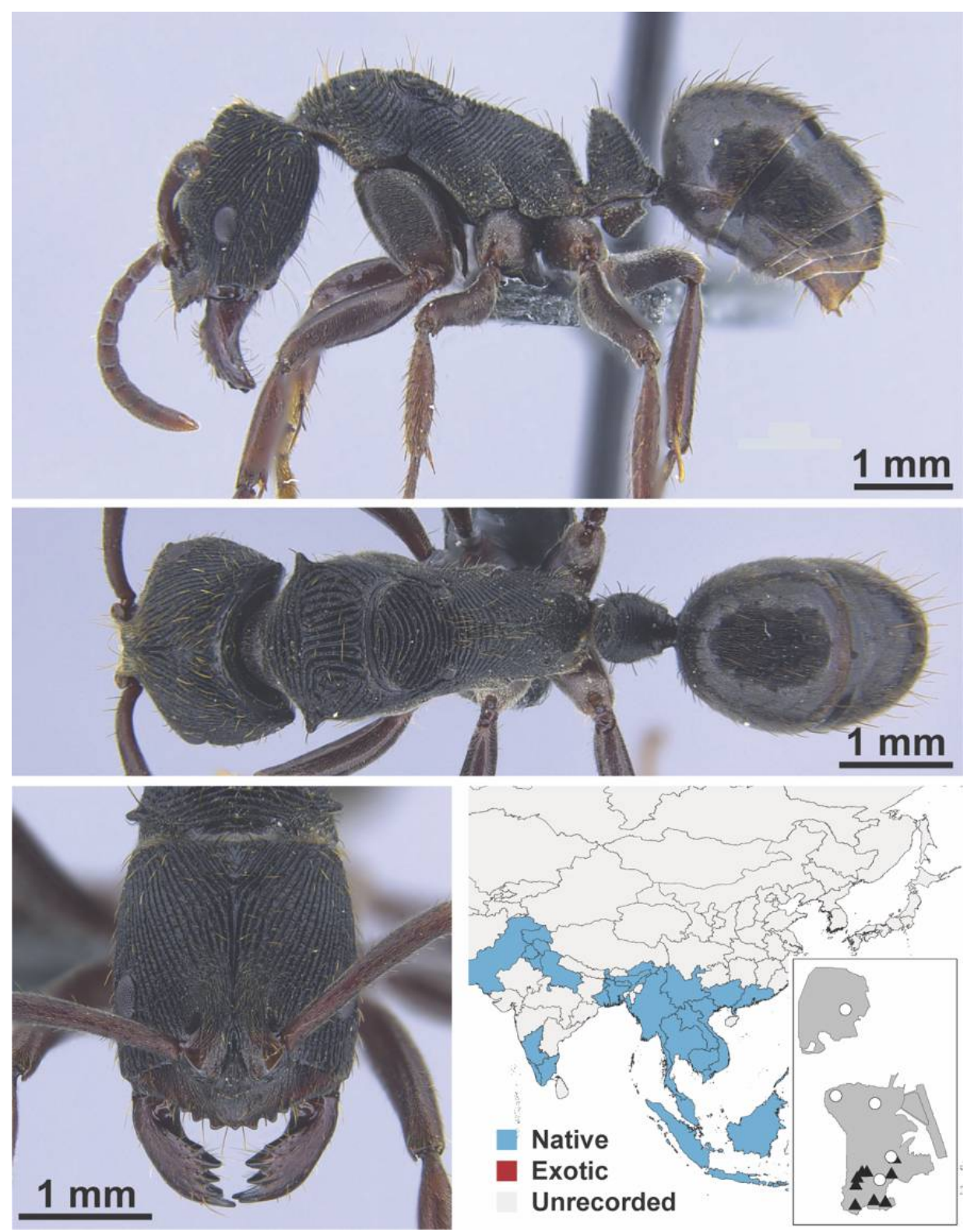

Figure A152. Odontoponera denticulata Smith, 1858 worker (MAC_S09_LLSA_Sp.3, IBBL). 


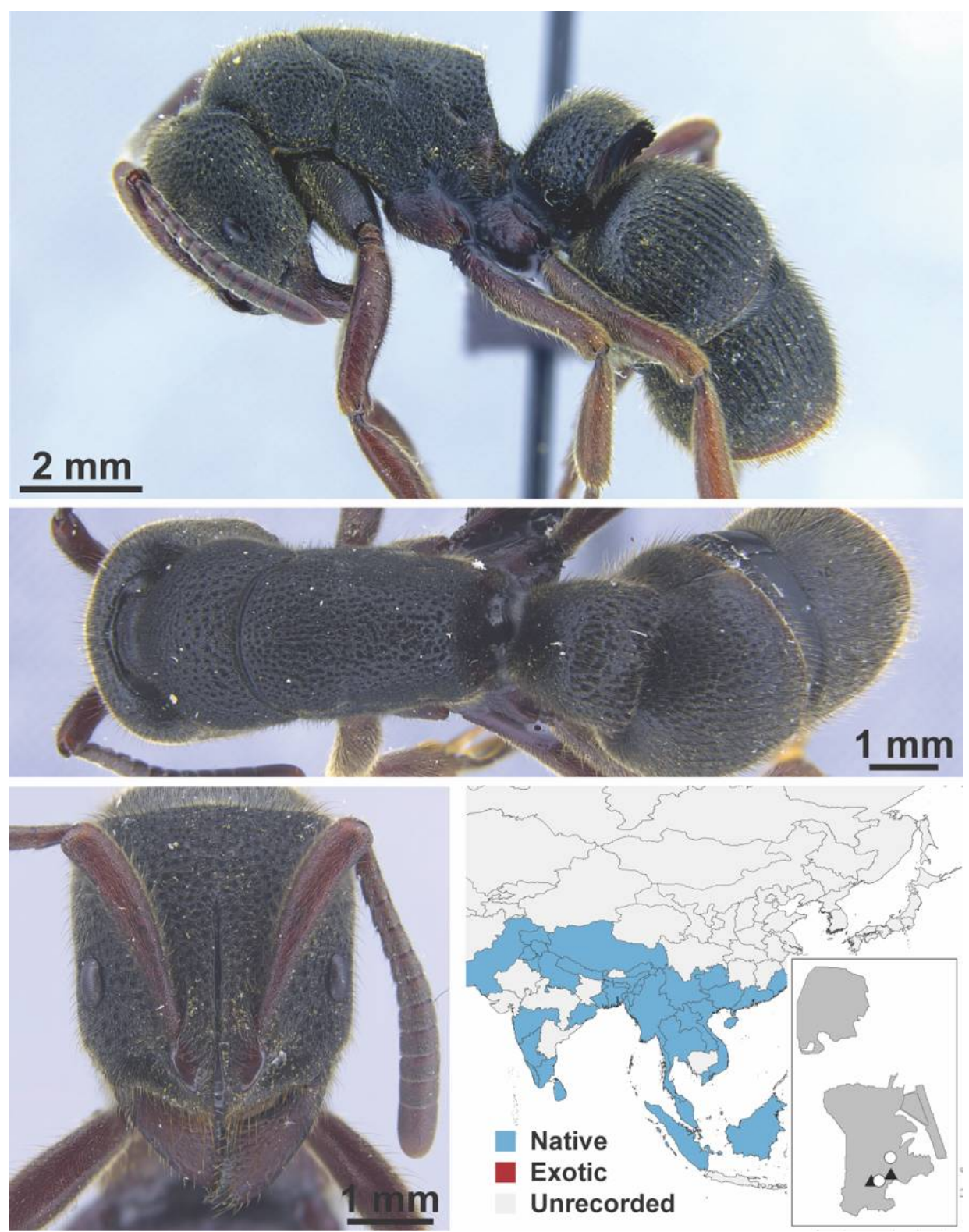

Figure A153. Pseudoneoponera rufipes Jerdon, 1851 worker (MAC_S03_LLSA_Sp.1, IBBL). 
Appendix A.8 PROCERATIINAE
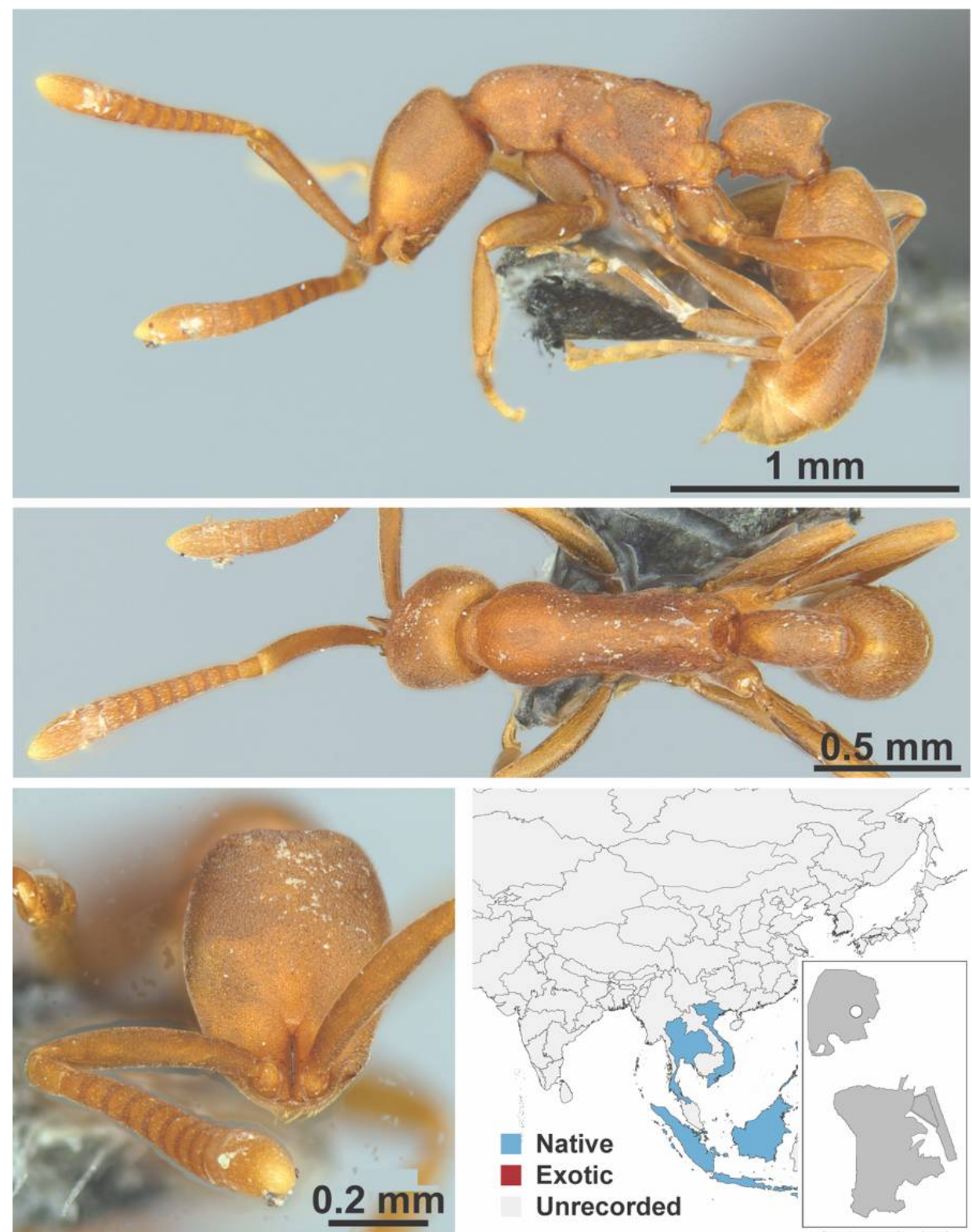

Figure A154. Probolomyrmex dammermani Wheeler, W. M., 1928 worker (Probolomyrmex dammermani, IBBL). 


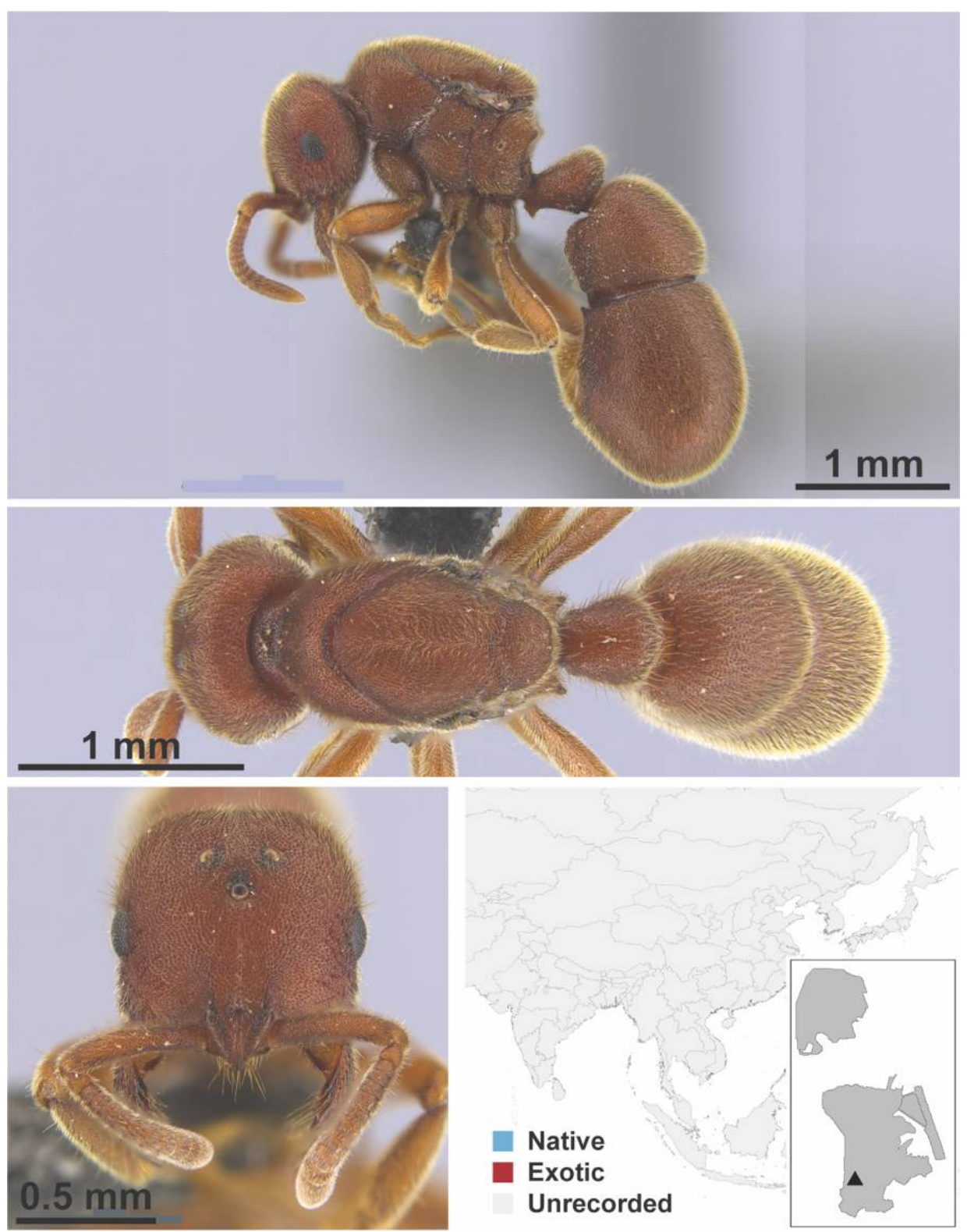

Figure A155. Proceratium sp. cf. bruelheidei Staab, Xu \& Hita Garcia, 2018 queen (MAC_S05_ LLSP_Sp.1, IBBL). 

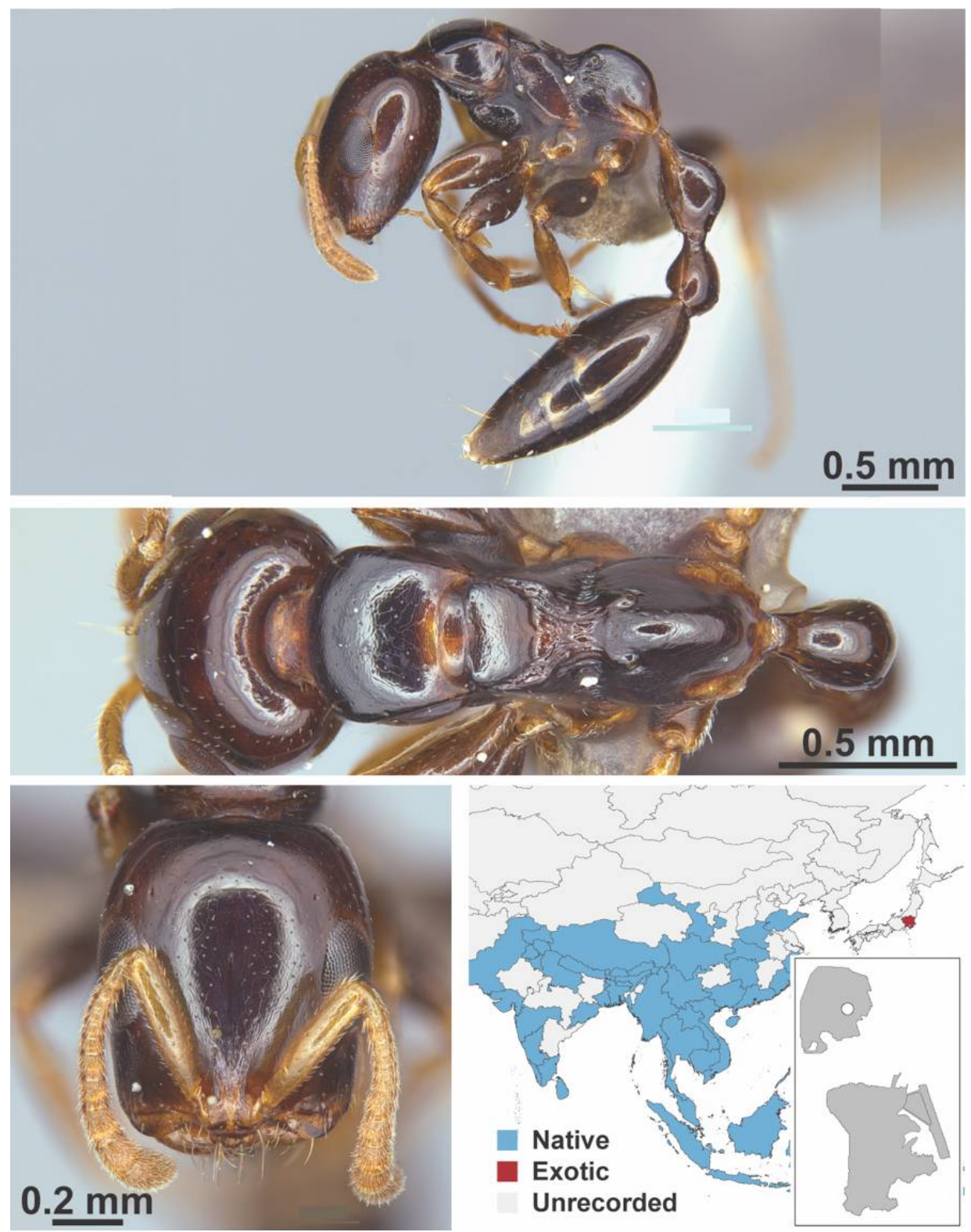

Figure A156. Tetraponera allaborans Walker, 1859 worker (Tetraponera allaborans, CML collection). 


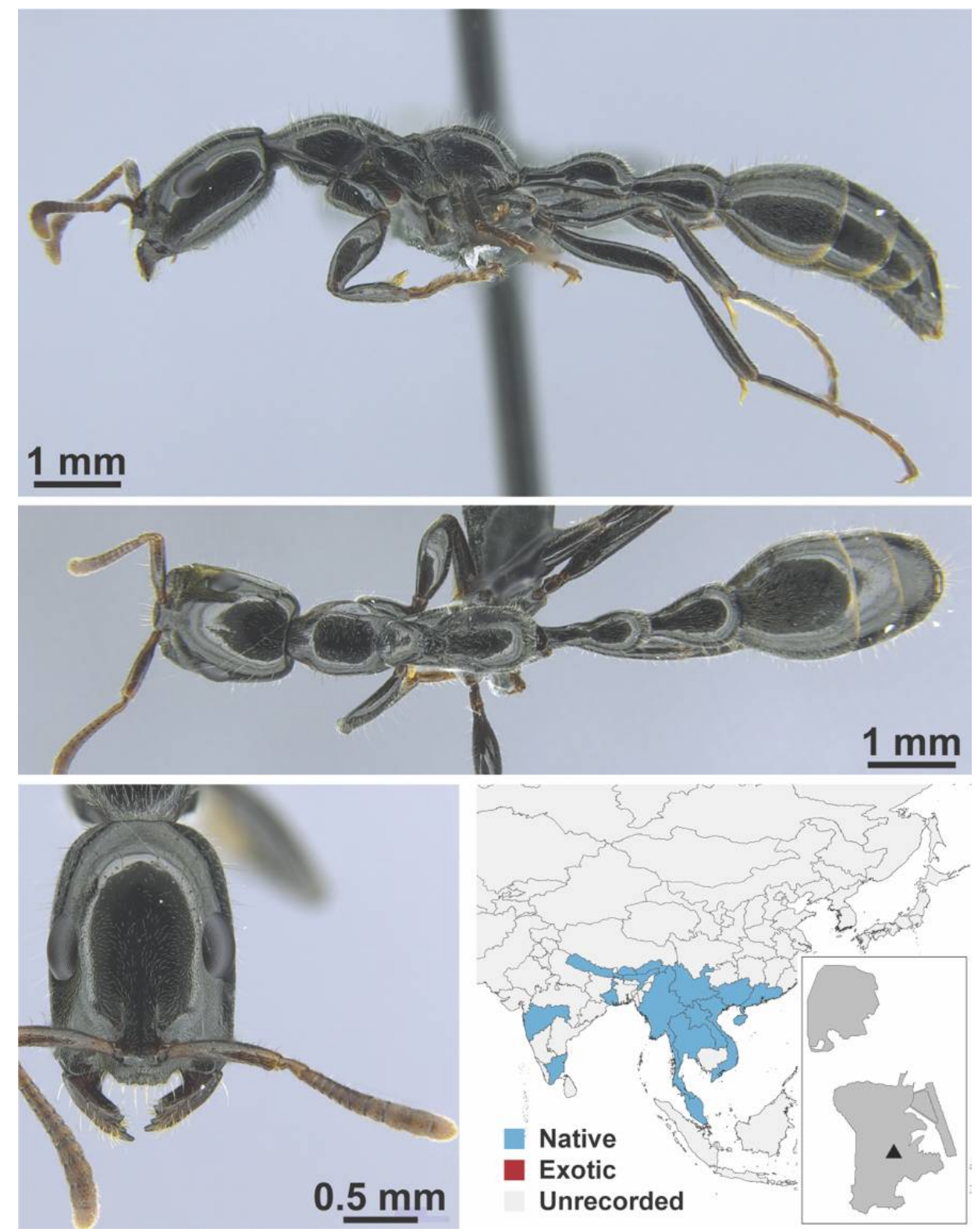

Figure A157. Tetraponera binghami Forel, 1902 worker (FB19140, IBBL). 

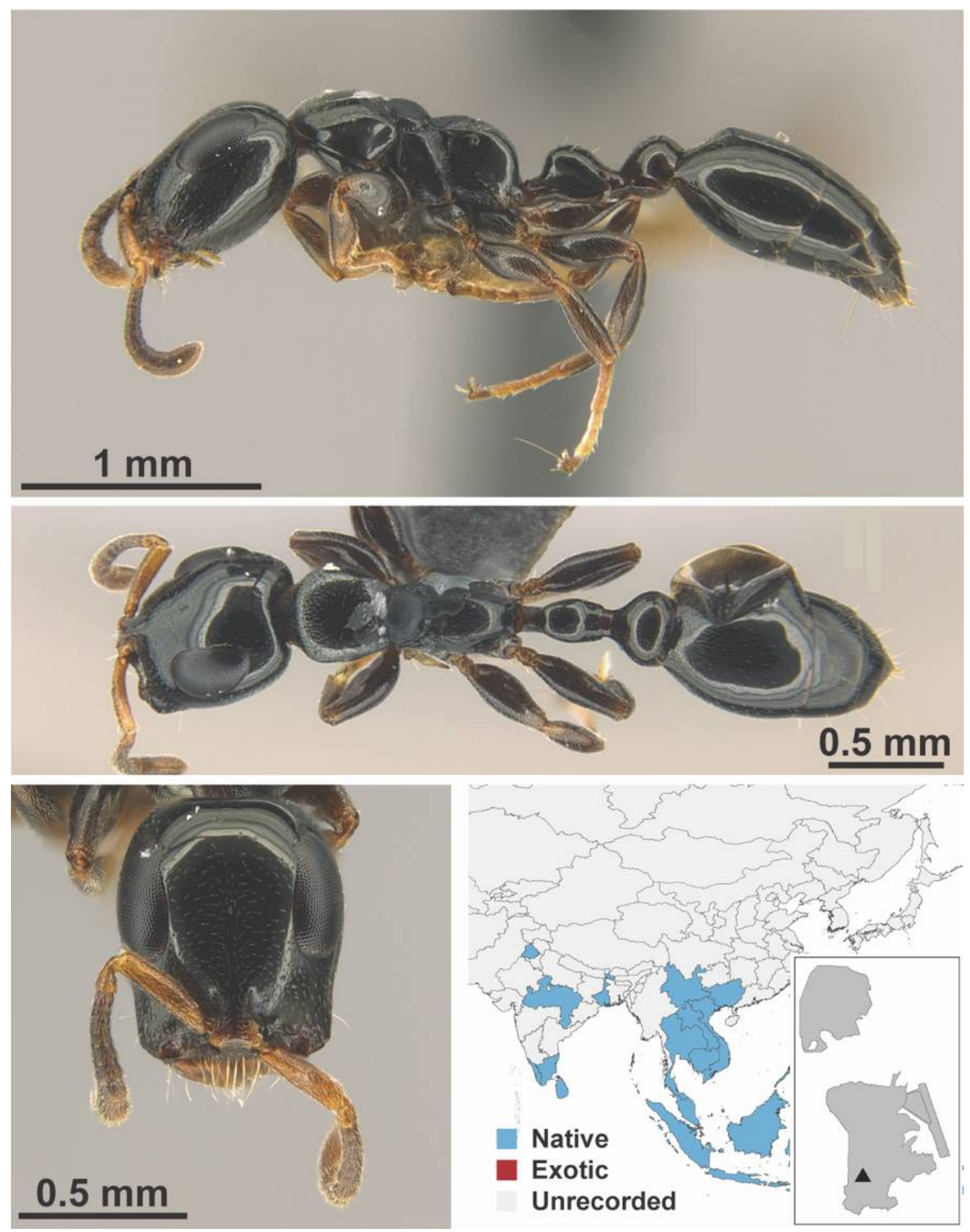

Figure A158. Tetraponera nitida Smith, 1860 worker (MAC_GOV_Workshop, IBBL).

\section{References}

1. United Nations. World Urbanization Prospects 2018, United Nations: New York, NY, USA, 2019.

2. Güneralp, B.; Seto, K.C. Futures of global urban expansion: Uncertainties and implications for biodiversity conservation. Environ. Res. Lett. 2013, 8,1-10. [CrossRef]

3. Batty, M. The size, scale, and shape of cities. Science (80-. ) 2008, 319, 769-771. [CrossRef] [PubMed]

4. McKinney, M.L. Effects of urbanization on species richness: A review of plants and animals. Urban Ecosyst. 2008, 11, 161-176. [CrossRef]

5. McKinney, M.L. Urbanization as a major cause of biotic homogenization. Biol. Conserv. 2006, 127, 247-260. [CrossRef]

6. Knop, E. Biotic homogenization of three insect groups due to urbanization. Glob. Chang. Biol. 2016, 22, 228-236. [CrossRef] [PubMed]

7. Fiera, C. Biodiversity of Collembola in urban soils and their use as bioindicators for pollution. Pesqui. Agropecuária Bras. 2009, 44, 868-873. [CrossRef]

8. Meyer, L.A.; Sullivan, S.M.P. Bright lights, big city: Influences of ecological light pollution on reciprocal stream-riparian invertebrate fluxes. Ecol. Appl. 2013, 23, 1322-1330. [CrossRef]

9. Pompeu, P.S.; Alves, C.B.M.; Callisto, M. The effects of urbanization on biodiversity and water quality in the Rio das Velhas Basin, Brazil. Am. Fish. Soc. Symp. 2005, 47, 11-22. 
10. Buczkowski, G.; Richmond, D.S. The effect of urbanization on ant abundance and diversity: A temporal examination of factors affecting biodiversity. PLOS ONE 2012, 7, 1-9. [CrossRef]

11. Wang, H.F.; López-Pujol, J.; Meyerson, L.A.; Qiu, J.X.; Wang, X.K.; Ouyang, Z.Y. Biological invasions in rapidly urbanizing areas: A case study of Beijing, China. Biodivers. Conserv. 2011, 20, 2483-2509. [CrossRef]

12. Lepczyk, C.A.; Aronson, M.F.J.; Evans, K.L.; Goddard, M.A.; Lerman, S.B.; Macivor, J.S. Biodiversity in the City: Fundamental Questions for Understanding the Ecology of Urban Green Spaces for Biodiversity Conservation. Bioscience 2017, 67, 799-807. [CrossRef]

13. Ives, C.D.; Lentini, P.E.; Threlfall, C.G.; Ikin, K.; Shanahan, D.F.; Garrard, G.E.; Bekessy, S.A.; Fuller, R.A.; Mumaw, L.; Rayner, L.; et al. Cities are hotspots for threatened species. Glob. Ecol. Biogeogr. 2016, 25, 117-126. [CrossRef]

14. Kowarik, I. Novel urban ecosystems, biodiversity, and conservation. Environ. Pollut. 2011, 159, 1974-1983. [CrossRef]

15. Aronson, M.F.J.; La Sorte, F.A.; Nilon, C.H.; Katti, M.; Goddard, M.A.; Lepczyk, C.A.; Warren, P.S.; Williams, N.S.G.; Cilliers, S.; Clarkson, B.; et al. A global analysis of the impacts of urbanization on bird and plant diversity reveals key anthropogenic drivers. Proc. R. Soc. B Biol. Sci. 2014, 281, 1-8. [CrossRef]

16. Guénard, B.; Cardinal-De Casas, A.; Dunn, R.R. High diversity in an urban habitat: Are some animal assemblages resilient to long-term anthropogenic change? Urban Ecosyst. 2015, 18, 449-463. [CrossRef]

17. Donnelly, R.; Marzluff, J.M. Importance of reserve size and landscape context to urban bird conservation. Conserv. Biol. 2004, 18, 733-745. [CrossRef]

18. Evans, K.L.; Newson, S.E.; Gaston, K.J. Habitat influences on urban avian assemblages. Ibis (Lond.) 2009, 151, 19-39. [CrossRef]

19. Shwartz, A.; Muratet, A.; Simon, L.; Julliard, R. Local and management variables outweigh landscape effects in enhancing the diversity of different taxa in a big metropolis. Biol. Conserv. 2013, 157, 285-292. [CrossRef]

20. Beninde, J.; Veith, M.; Hochkirch, A. Biodiversity in cities needs space: A meta-analysis of factors determining intra-urban biodiversity variation. Ecol. Lett. 2015, 18, 581-592. [CrossRef] [PubMed]

21. Mack, R.N.; Simberloff, D.; Lonsdale, W.M.; Evans, H.; Clout, M.; Bazzaz, F.A. Biotic invasions: Causes, epidemiology, global consequences, and control. Ecol. Appl. 2000, 10, 689-710. [CrossRef]

22. Kowarik, I. On the role of alien species in urban flora and vegetation. In Urban Ecology: An International Perspective on the Interaction Between Humans and Nature; Marzluff, J., Shulenberger, E., Endlicher, W., Alberti, M., Bradley, G., Ryan, C., ZumBrunnen, C., Simon, U., Eds.; Springer: New York, NY, USA, 2008; p. 802. ISBN 9780387734118.

23. Ricotta, C.; La Sorte, F.A.; Pyšek, P.; Rapson, G.L.; Celesti-Grapow, L.; Thompson, K. Phyloecology of urban alien floras. J. Ecol. 2009, 97, 1243-1251. [CrossRef]

24. Costello, C.; Springborn, M.; McAusland, C.; Solow, A. Unintended biological invasions: Does risk vary by trading partner? J. Environ. Econ. Manag. 2007, 54, 262-276. [CrossRef]

25. Wittig, R. The origin and development of the urban flora of Central Europe. Urban Ecosyst. 2004, 7, 323-329. [CrossRef]

26. Von Der Lippe, M.; Kowarik, I. Do cities export biodiversity? Traffic as dispersal vector across urban-rural gradients. Divers. Distrib. 2008, 14, 18-25. [CrossRef]

27. Dawson, W.; Moser, D.; Van Kleunen, M.; Kreft, H.; Pergl, J.; Pyšek, P.; Weigelt, P.; Winter, M.; Lenzner, B.; Blackburn, T.M.; et al. Global hotspots and correlates of alien species richness across taxonomic groups. Nat. Ecol. Evol. 2017, 1, 1-7. [CrossRef]

28. Lu, J.; Li, S.P.; Wu, Y.; Jiang, L. Are Hong Kong and Taiwan stepping-stones for invasive species to the mainland of China? Ecol. Evol. 2018, 8, 1966-1973. [CrossRef] [PubMed]

29. Underwood, E.C.; Fisher, B.L. The role of ants in conservation monitoring: If, when, and how. Biol. Conserv. 2006, 132, 166-182. [CrossRef]

30. Agosti, D.; Majer, J.D.; Alonso, L.E.; Schultz, T.R. Standard Methods for Measuring and Monitoring Biodiversity; Smithsonian Institution Press: Washington, DC, USA, 2000; ISBN 1560988584.

31. Hölldobler, B.; Wilson, E.O. The Ants; Belknap Press of Harvard University Press: Cambridge, MA, USA, 1990; Volume N1, ISBN 0674040759.

32. Lach, L.; Parr, C.L.L.; Abbott, K. Ant Ecology, 1st ed.; Oxford University Press: Oxford, UK, 2010.

33. Andersen, A.N.; Majer, J.D. Ants show the way Down Under: Invertebrates as bioindicators in land management. Front. Ecol. Environ. 2004, 2, 291-298. [CrossRef]

34. Folgarait, P.J. Ant biodiversity and its relationship to ecosystem functioning: A review. Biodivers. Conserv. 1998, 7, 1221-1244. [CrossRef]

35. Holway, D.A.; Lach, L.; Suarez, A.V.; Tsutsui, N.D.; Case, T.J. The causes and consequences of ant invasions. Annu. Rev. Ecol. Syst. 2002, 33, 181-233. [CrossRef]

36. Holway, D.A. Edge effects of an invasive species across a natural ecological boundary. Biol. Conserv. 2005, 121, 561-567. [CrossRef]

37. Human, K.G.; Gordon, D.M. Exploitation and interference competition between the invasive Argentine ant, Linepithema humile, and native ant species. Oecologia 1996, 105, 405-412. [CrossRef]

38. Gerlach, J. Impact of the invasive crazy ant Anoplolepis gracilipes on Bird Island, Seychelles. J. Insect Conserv. 2004, 8, 15-25. [CrossRef]

39. Allen, C.R.; Birge, H.E.; Slater, J.; Wiggers, E. The invasive ant, Solenopsis invicta, reduces herpetofauna richness and abundance. Biol. Invasions 2017, 19, 713-722. [CrossRef]

40. Ness, J.H.; Bronstein, J.L. The effects of invasive ants on prospective ant mutualists. Biol. Invasions 2004, 6, 445-461. [CrossRef] 
41. O'Dowd, D.J.; Green, P.T.; Lake, P.S. Invasional "meltdown" on an oceanic island. Ecol. Lett. 2003, 6, 812-817. [CrossRef]

42. Chan, K.H.; Guénard, B. Ecological and socio-economic impacts of the red import fire ant, Solenopsis invicta (Hymenoptera: Formicidae), on urban agricultural ecosystems. Urban Ecosyst. 2020, 23, 1-12. [CrossRef]

43. Lee, C.Y. Tropical Household Ants: Pest Status, Species Diversity, Foraging Behavior, and Baiting Studies. In Proceedings of the 4th International Conference on Urban Pests, Charleston, SC, USA, 7-10 July 2002.

44. Klotz, J.H.; Mangold, J.R.; Vail, K.M.; Davis, L.R.; Patterson, R.S. A survey of the urban pest ants (Hymenoptera: Formicidae) of Peninsular Florida. Florida Entomol. 1995, 78, 109-118. [CrossRef]

45. Fowler, H.G.; Bueno, O.C.; Sadatsune, T.; Montelli, A.C. Ants as potential vectors of pathogens in hospitals in the state of sao paulo, brazil. Int. J. Trop. Insect Sci. 1993, 14, 367-370. [CrossRef]

46. Beatson, S.H. Pharaoh's ants as pathogen vectors in hospitals. Lancet 1972, 1, 425-427. [CrossRef]

47. Brühl, C.A.; Gunsalam, G.; Linsenmair, K.E. Stratification of ants (Hymenoptera, Formicidae) in a primary rain forest in Sabah, Borneo. J. Trop. Ecol. 1998, 14, 285-297. [CrossRef]

48. Martins, M.F.d.O.; Thomazini, M.J.; Baretta, D.; Brown, G.G.; da Rosa, M.G.; Zagatto, M.R.G.; Santos, A.; Nadolny, H.S.; Cardoso, G.B.X.; Niva, C.C.; et al. Accessing the subterranean ant fauna (Hymenoptera: Formicidae) in native and modified subtropical landscapes in the neotropics. Biota Neotrop. 2020, 20,1-16. [CrossRef]

49. Wilkie, K.T.R.; Mertl, A.L.; Traniello, J.F.A. Species diversity and distribution patterns of the ants of Amazonian ecuador. PLoS ONE 2010, 5, 1-12. [CrossRef]

50. Wong, M.K.L.; Guénard, B. Subterranean ants: Summary and perspectives on field sampling methods, with notes on diversity and ecology (Hymenoptera: Formicidae). Myrmecol. News 2017, 25, 1-16. [CrossRef]

51. Houadria, M.; Menzel, F. Digging deeper into the ecology of subterranean ants: Diversity and niche partitioning across two continents. Diversity 2021, 13, 53. [CrossRef]

52. Santos, M.N. Research on urban ants: Approaches and gaps. Insectes Soc. 2016, 63, 359-371. [CrossRef]

53. Leong, C.M.; Shiao, S.F.; Guénard, B. Ants in the city, a preliminary checklist of Formicidae (Hymenoptera) in Macau, one of the most heavily urbanized regions of the world. Asian Myrmecol. 2017, 9, 1-20. [CrossRef]

54. Brassard, F.; Leong, C.M.; Chan, H.H.; Guénard, B. A new subterranean species and an updated checklist of Strumigenys (Hymenoptera, formicidae) from Macao SAR, China, with a key to species of the greater bay area. Zookeys 2020, 970, 63-116. [CrossRef]

55. Wong, T.L.; Guénard, B. Review of ants from the genus Polyrhachis Smith (Hymenoptera:Formicidae:Formicinae) in Hong Kong and Macau, with notes on their natural history. Asian Myrmecol. 2021; 13, 1-70. [CrossRef]

56. Hui, E.C.M.; Li, X.; Chen, T.; Lang, W. Deciphering the spatial structure of China's megacity region: A new bay area-The Guangdong-Hong Kong-Macao Greater Bay Area in the making. Cities 2018, 105, 1-13. [CrossRef]

57. Statistics and Census Service Yearbook of Statistics 2019. Available online: www.dsec.gov.mo (accessed on 23 July 2021).

58. Grydehoj, A. Making Ground, Losing Space: Land Reclamation and Urban Public Space in Island Cities. Urban Isl. Stud. 2015, 1, 96-117. [CrossRef]

59. Chen, B.; Yang, Q.; Zhou, S.; Li, J.S.; Chen, G.Q. Urban economy's carbon flow through external trade: Spatial-temporal evolution for Macao. Energy Policy 2017, 110, 69-78. [CrossRef]

60. Ptak, R.; Souza, G.B. The Survival of Empire: Portuguese Trade and Society in China and the South China Sea, 1630-1754. J. Am. Orient. Soc. 1988, 108, 1630-1754. [CrossRef]

61. Leong, C.M.; Yamane, S.; Guénard, B. Lost in the city: Discovery of the rare ant genus Leptanilla (Hymenoptera: Formicidae) in Macau with description of Leptanilla macauensis sp. nov. Asian Myrmecol. 2018, 10, 1-16. [CrossRef]

62. Kouakou, L.M.M.; Yeo, K.; Kone, M.; Ouattara, K.; Kouakou, A.K.; Delsinne, T.; Dekoninck, W. Espaces verts comme une alternative de conservation de la biodiversité en villes: Le cas des fourmis (Hyménoptère: Formicidae) dans le district d'Abidjan (Côte d'Ivoire). J. Appl. Biosci. 2019, 131, 13359-13381. [CrossRef]

63. Yeo, K.; Dekoninck, W.; Kouakou, L.M.; Ouattara, K.; Konate, S. Detecting intruders: Assessment of the anthropophilic ant fauna (Hymenoptera: Formicidae) in the city of Abidjan and along access roads in Banco National Park (Côte d'Ivoire). J. Entomol. Zool. Stud. JEZS 2016, 4, 351-359.

64. Kasseney, B.D.; N'tie, T.B.; Nuto, Y.; Wouter, D.; Yeo, K.; Glitho, I.A. Diversity of ants and termites of the botanical garden of the university of lomé, Togo. Insects 2019, 10, 218. [CrossRef]

65. Taheri, A.; Wetterer, J.K.; Reyes-López, J. Tramp ants of Tangier, Morocco. Trans. Am. Entomol. Soc. 2017, 143, 267-270. [CrossRef]

66. Bernard, F. Fourmis des villes et fourmis du bled entre Rabat et Tanger. Société Sci. Nat. Phys. Maroc 1958, 38, 131-142.

67. Bernard, F. Les Fourmis des rues de Kenitra (Maroc) [Hym.]. Bull. Société Entomol. Fr. 1974, 79, $178-183$.

68. Reyes-López, J.; Carpintero, S. Comparison of the exotic and native ant communities (Hymenoptera: Formicidae) in urban green areas at inland, Coastal and insular sites in Spain. Eur. J. Entomol. 2014, 111, 421-428. [CrossRef]

69. Ito, F.; Yamane, S.; Eguchi, K.; Noerdjito, W.A.; Kahono, S.; Tsuji, K.; Ohkawara, K.; Yamauchi, K.; Nishida, T.; Nakamura, K. Ant Species Diversity in the Bogor Botanic Garden, West Java, Indonesia, with Descriptions of Two New Species of the Genus Leptanilla (Hymenoptera, Formicidae). Tropics 2001, 10, 379-404. [CrossRef]

70. Rizali, A.; Bos, M.M.; Buchori, D.; Yamane, S.; Schulze, C.H. Ants in Tropical Urban Habitats: The Myrmecofauna in a Densely Populated Area of Bogor, West Java, Indonesia. HAYATI J. Biosci. 2008, 15, 77-84. [CrossRef]

71. Terayama, M. Ants from the Akasaka Imperial Gardens, Tokyo. Mem. Natl. Sci. Museum 2005, 39, $239-243$. 
72. Terayama, M. Ants from the Tokiwamatsu Imperial Gardens, Tokyo. Mem. Natl. Sci. Museum Tokyo 2005, 39, $245-247$.

73. Terayama, M. Ants (Formicidae) from the imperial Palace, Tokyo. Mem. Natl. Sci. Museum Tokyo 2014, 50, 527-535.

74. Matsumura, S.; Yamane, S. Species composition and dominant species of ants in Jigenji Park, Kagoshima City, Japan. Nat. Kagoshima 2012, 38, 99-107.

75. Liu, K.L.; Peng, M.H.; Hung, Y.C.; Neoh, K.B. Effects of park size, peri-urban forest spillover, and environmental filtering on diversity, structure, and morphology of ant assemblages in urban park. Urban Ecosyst. 2019, 22, 643-656. [CrossRef]

76. Natuhara, Y. Ant faunae in Osaka City and three sites in Osaka Prefecture. ARI J. Myrmecol. Soc. Jpn. 1998, 22, 1-5.

77. Tan, C.K.W.; Corlett, R.T. Scavenging of dead invertebrates along an urbanisation gradient in Singapore. Insect Conserv. Divers. 2012, 5, 138-145. [CrossRef]

78. Harada, Y.; Koto, S.; Kawaguchi, N.; Sato, K.; Setoguchi, T.; Muranaga, R.; Yamashita, H.; Yo, A.; Yamane, S. Ants of Jusso, Isa City, Kagoshima Prefecture, southwestern Japan. Bull. Biogeogr. Soc. Jpn. 2012, 67, 143-152.

79. Iwata, K.; Eguchi, K.; Yamane, S. A Case Study on Urban Ant Fauna of Southern Kyusyu, Japan, with Notes on a New Monitoring Protocol (Insecta, Hymenoptera, Formicidae). J. Asia. Pac. Entomol. 2005, 8, 263-272. [CrossRef]

80. Yamaguchi, T. Influence of urbanization on ant distribution in parks of Tokyo and Chiba City, Japan I. Analysis of ant species richness. Ecol. Res. 2004, 19, 209-216. [CrossRef]

81. Park, S.H.; Hosoishi, S.; Ogata, K.; Kasuya, E. Changes of species diversity of ants over time: A case study in two urban parks. J. Fac. Agric. Kyushu Univ. 2014, 59, 71-76. [CrossRef]

82. Wang, W.; Zhang, S.; Xu, Z. Distribution patterns of ant species in Shenzhen City. J. Southwest For. Univ. 2012, $32,69-74$.

83. Khot, K.; Quadros, G.; Somani, V. Ant Diversity in an urban garden at Mumbai, Maharashtra. In Proceedings of the National Conference on Biodiversity: Status and Challenges in Conservation-FAVEO, Thane, India, 29-30 November 2013; 2013, pp. 121-125.

84. Hiroyuki, Y. List of species of Hymenoptera and Diptera in Matsuyama City, Ehime Prefecture, Shikoku, Japan. Comm. Surv. Nat. Environ. Matsuyama City 2012, 167-176.

85. Harada, Y.; Yamasaki, M.; Saito, N.; Higasayama, U. Spreading of Technomyrmex brunneus in Shiroyama Park, Kagoshima City, southern Japan. Nat. Kagoshima 2021, 47, 275-279.

86. Miyake, K. Effect of Argentine ant invasions on Japanese ant fauna in Hiroshima Prefecture, western Japan: Preliminary report (Hymenoptera: Formicidae). Sociobiology 2002, 39, 65-474.

87. Tan, S.; Wei, H.; Liu, D. An investigation of ant species in houses and courtyards in the Chengdu area. Sichuan J. Zool. 2009, 28, 870-873.

88. Park, S.H.; Hosoishi, S.; Ogata, K. Long-term impacts of argentine ant invasion of urban parks in Hiroshima, Japan. J. Ecol. Environ. 2014, 37, 123-129. [CrossRef]

89. Touyama, Y.; Ogata, K.; Sugiyama, T. The Argentine ant, Linepithema humile, in Japan: Assessment of impact on species diversity of ant communities in urban environments. Entomol. Sci. 2003, 6, 57-62. [CrossRef]

90. Harada, Y.; Yamashita, M. Ants in the parks of the ruins of castles in Shikoku, western Japan. Nat. Kagoshima 2019, 46, 171-175.

91. Malozemova, L.A.; Malozemov, Y.A. Ecological Peculiarities of Ants in Urbanized Areas. Russ. J. Ecol. 1999, $30,283-286$.

92. Harada, Y. Ant fauna in Joyama Park, Hioki City, Kagoshima Prefecture, Japan, after the Technomyrmex brunneus invasion. Nat. Kagoshima 2020, 47, 173-178.

93. Roshanak, T.; Pashaei Rad, S.; Shokri, M. Faunistic investigation of ant (Hymenoptera: Formicidae) in the vicinity of Shiraz. Environ. Sci. 2017, 15, 75-91.

94. Hosoishi, S.; Rahman, M.M.; Murakami, T.; Park, S.H.; Kuboki, Y.; Ogata, K. Winter activity of ants in an urban area of western Japan. Sociobiology 2019, 66, 414-419. [CrossRef]

95. Terayama, M. Effects of the invasive ants Linepithema humile (Hymenoptera: Formicidae) on native ant and homopterous insect ommunities in Japan. ARI J. Myrmecol. Soc. Jpn. 2006, 28, 13-27.

96. Putyatina, T.S.; Perfilieva, K.S.; Zakalyukina, Y.V. Typification of urban habitats, with ant assemblages of Moscow city taken as an example. Entomol. Rev. 2017, 97, 1053-1062. [CrossRef]

97. Kumar, D.; Mishra, A. Ant community variation in urban and agricultural ecosystems in Vadodara District (Gujarat State), western India. Asian Myrmecol. 2008, 2, 85-93.

98. Antonov, I.A. Ant Assemblages of Two Cities with Different Ecological Conditions in Southern Cisbaikalia. Russ. J. Ecol. 2008, 39, 454-456. [CrossRef]

99. Hosaka, T.; Di, L.; Eguchi, K.; Numata, S. Ant assemblages on littered food waste and food removal rates in urban-suburban parks of Tokyo. Basic Appl. Ecol. 2019, 37, 1-9. [CrossRef]

100. Blinova, S.V. Changes in ant assemblages under conditions of a large industrial center. Russ. J. Ecol. 2008, 39, 148-150. [CrossRef]

101. Meshram, H.; Chavahan, P.; Sangode, V.; Khandwekar, V. Distribution of ant fauna in different terrestrial ecosystem in and around Nagpur city, Maharashtra India. J. Entomol. Zool. Stud. 2015, 3, 215-218.

102. Yong, G.W.J.; Wong, M.K.L.; Soh, E.J.Y. A preliminary checklist of the ant genera of Pulau Ubin, Singapore, from rapid opportunistic sampling (Hymenoptera: Formicidae). Nat. Singap. 2017, 10, 55-66.

103. Ossola, A.; Nash, M.A.; Christie, F.J.; Hahs, A.K.; Livesley, S.J. Urban habitat complexity affects species richness but not environmental filtering of morphologically-diverse ants. PeerJ 2015, 3, 1-19. [CrossRef] 
104. Heterick, B.E.; Lythe, M.; Smithyman, C. Urbanisation factors impacting on ant (Hymenoptera: Formicidae) biodiversity in the Perth metropolitan area, Western Australia: Two case studies. Urban Ecosyst. 2013, 16, 145-173. [CrossRef]

105. Majer, J.D.; Brown, K.R. The effects of urbanization on the ant fauna of the Swan Coastal Plain near Perth, Western Australia. J. R. Soc. West. Aust. 1986, 69, 13-17.

106. Callan, S.K.; Mater, J.D. Impacts of an incursion of African Big-headed Ants, Pheidole megacephala (Fabricius), in urban bushland in Perth, Western Australia. Pacific Conserv. Biol. 2009, 15, 102-115. [CrossRef]

107. Heterick, B.E.; Majer, J.D. Influence of Argentine and coastal brown ant (Hymenoptera: Formicidae) invasions on ant communities in Perth gardens, Western Australia. Urban Ecosyst. 2000, 4, 277-292. [CrossRef]

108. May, J.E.; Heterick, B.E. Effects of the coastal brown ant Pheidole megacephala (Fabricius), on the ant fauna of the Perth metropolitan region, Western Australia. Pacific Conserv. Biol. 2000, 6, 81-85. [CrossRef]

109. Radchenko, A.G.; Stukalyuk, S.V.; Netsvetov, M.V. Ants (Hymenoptera, Formicidae) of Kyiv. Entomol. Rev. 2019, 99, 753-773. [CrossRef]

110. Ordóñez-Urbano, C.; Reyes López, J.; Carpintero-Ortega, S. ¿Una especie alóctona se puede ser "rara"?: El caso de Pyramica membranifera (Hymenoptera, Formicidae). Bol. Soc. Entomológica Aragon. 2008, 42, 321-323.

111. Antonova, V.; Penev, L. Change in the zoogeographical structure of ants caused by urban pressure in the Sofia region (Bulgaria). Mymecol. News 2006, 8, 271-276.

112. Penev, L.; Stoyanov, I.; Dedov, I.; Antonova, V. Patterns of Urbanisation in the City of Sofia as Shown by Carabid Beetles (Coleoptera, Carabidae), Ants (Hymenoptera, Formicidae), and Terrestrial Gastropods (Mollusca, Gastropoda Terrestria). In Back to the Roots and Back to the Future: Towards A New Synthesis Amongst Taxonomic, Ecological and Biogeographical Approaches in Carabidology, Proceedings of the XIII European Carabidologists Meeting, Blagoevgrad, Bulgaria, 20-24 August 2007; Pensoft: Moscow, Russia, 2008; pp. 483-509.

113. Antonova, V.; Lyubomir, P. Classification of Ant Assemblages (Hymenoptera: Formicidae) in Green Areas of Sofia. Acta Zool. Bulg. 2008, 2, 103-110. [CrossRef]

114. Dauber, J.; Eisenbeis, G. Untersuchungen zur Ameisenfauna einer urbanen Landschaft am Beispiel der Stadt Mainz. Abh. Ber. Naturkundemus. Görlitz 1997, 69, 237-244.

115. Pisarski, B.; Czechowski, W. Influence de la pression urbaine sur la myrmécofaune. Memorab. Zool. 1978, 29, 109-128.

116. Pisarski, B. Ants (Hymenoptera, Formicoidea) of Warzaw and Mazovia. Memorab. Zool. 1982, 36, 73-90.

117. Heras, P.R.; Ibáñez, M.D.M.; Sañudo, F.J.C.; Martínez, M.d.l.Á.V. Primeros datos de Formícidos (Hymenoptera, Formicidae) en parques urbanos de Madrid. Boletín la Asoc. Española Entomol. 2011, 35, 93-112.

118. Klesniaková, M.; Holecová, M.; Pavlíková, A. Interesting ant species in the urban greenery of Bratislava. Folia Faun. Slovaca 2016, 21, 235-238.

119. Trigos-Peral, G.; Rutkowski, T.; Witek, M.; Ślipiński, P.; Babik, H.; Czechowski, W. Three categories of urban green areas and the effect of their different management on the communities of ants, spiders and harvestmen. Urban Ecosyst. 2020, 23, 803-818. [CrossRef]

120. Ješovnik, A.; Bujan, J. Wooded areas promote species richness in urban parks. Urban Ecosyst. 2021, 1-11. [CrossRef]

121. Behr, D.; Lippke, S.; Cölln, K. Zur Kenntnis der Ameisen von Köln (Hymenoptera, Formicidae). Dechen. Beih. 1996, 35, 215-232.

122. Ślipiński, P.; ZMihorski, M.; Czechowski, W. Species diversity and nestedness of ant assemblages in an urban environment. Eur. J. Entomol. 2012, 109, 197-206. [CrossRef]

123. Behr, D.; Cölln, K. Zur Ameisenfauna (Hymenoptera, Formicidae) von Gönnersdorf. Dendrocopos 1993, 20, 148-160.

124. Rigato, F.; Wetterer, J.K. Ants (Hymenoptera: Formicidae) of San Marino. Nat. Hist. Sci. 2018, 5. [CrossRef]

125. Espadaler, X.; López-Soria, L. Rareness of certain Mediterranean ant species: Fact or artifact? Insectes Soc. 1991, 38, 365-377. [CrossRef]

126. Vepsäläinen, K.; Ikonen, H.; Koivula, M.J. The structure of ant assemblages in an urban area of Helsinki, southern Finland. Ann. Zool. Fennici 2008, 45, 109-127. [CrossRef]

127. Trigos-Peral, G.; Reyes-López, J.L. Las hormigas como bioindicadores para la gestión de zonas verdes urbanas en el sur de la Península Ibérica. Propuesta de grupos funcionales. Iberomyrmex 2016, 8, 37-38.

128. Stukalyuk, S.V. Stratification of the ant species (Hymenoptera, Formicidae) in the urban broadleaf woodlands of the city of Kiev. Entomol. Rev. 2017, 97, 320-343. [CrossRef]

129. Reyes López, J.L.; Taheri, A. First checklist of ants (Hymenoptera, Formicidae) of urban green areas in Cádiz (Andalusia, Spain). Boletín Asoc. Española Entomol. 2018, 42, 217-223.

130. Smith, J.; Chapman, A.; Eggleton, P. Baseline biodiversity surveys of the soil macrofauna of London's green spaces. Urban Ecosyst. 2006, 9, 337-349. [CrossRef]

131. Gaspar, C.; Thirion, C. Modification des populations d'Hyménoptères sociaux dans des milieux anthropogènes. Memorab. Zool. 1978, 29, 61-77.

132. Nuhn, T.P.; Wright, C.G. An Ecological Survey of Ants (Hymenoptera: Formicidae) in a Landscaped Suburban Habitat. Am. Midl. Nat. 1979, 102, 353-362. [CrossRef]

133. Baena, M.L.; Escobar, F.; Valenzuela, J.E. Diversity snapshot of green-gray space ants in two Mexican cities. Int. J. Trop. Insect Sci. 2020, 40, 239-250. [CrossRef] 
134. Menke, S.B.; Guénard, B.; Sexton, J.O.; Weiser, M.D.; Dunn, R.R.; Silverman, J. Urban areas may serve as habitat and corridors for dry-adapted, heat tolerant species; an example from ants. Urban Ecosyst. 2011, 14, 135-163. [CrossRef]

135. Miguelena, J.G.; Baker, P.B. Effects of Urbanization on the Diversity, Abundance, and Composition of Ant Assemblages in an Arid City. Environ. Entomol. 2019, 48, 836-846. [CrossRef]

136. Rocha-Ortega, M.; Castaño-Meneses, G. Effects of urbanization on the diversity of ant assemblages in tropical dry forests, Mexico. Urban Ecosyst. 2015, 18, 1373-1388. [CrossRef]

137. Toennisson, T.A.; Sanders, N.J.; Klingeman, W.E.; Vail, K.M. Influences on the structure of suburban ant (Hymenoptera: Formicidae) communities and the abundance of Tapinoma sessile. Environ. Entomol. 2011, 40, 1397-1404. [CrossRef]

138. Suarez, A.V.; Bolger, D.T.; Case, T.J. Effects of fragmentation and invasion on native ant communities in coastal southern California. Ecology 1998, 79, 2041. [CrossRef]

139. Gochnour, B.M.; Suiter, D.R.; Booher, D. Ant (Hymenoptera: Formicidae) Fauna of the Marine Port of Savannah, Garden City, Georgia (USA). J. Entomol. Sci. 2019, 54, 417-429. [CrossRef]

140. Savage, A.M.; Hackett, B.; Guénard, B.; Youngsteadt, E.K.; Dunn, R.R. Fine-scale heterogeneity across Manhattan's urban habitat mosaic is associated with variation in ant composition and richness. Insect Conserv. Divers. 2015, 8, 216-228. [CrossRef]

141. Friedrich, R.; Philpott, S.M. Nest-site limitation and nesting resources of ants (Hymenoptera: Formicidae) in urban green spaces. Environ. Entomol. 2009, 38, 600-607. [CrossRef]

142. García-Martínez, M.A.; Vanoye-Eligio, V.; Leyva-Ovalle, O.R.; Zetina-Córdoba, P.; Aguilar-Méndez, M.J.; Rosas-Mejía, M. Diversity of ants (hymenoptera: Formicidae) in a sub-montane and sub-tropical cityscape of northeastern Mexico. Sociobiology 2019, 66, 440-447. [CrossRef]

143. Fairweather, A.D.; Lewis, J.H.; Hunt, L.; McAlpine, D.F.; Smith, M.A. Ants (Hymenoptera: Formicidae) of Rockwood Park, New Brunswick: An Assessment of Species Richness and Habitat. Northeast. Nat. 2020, 27, 576-584. [CrossRef]

144. Uno, S.; Cotton, J.; Philpott, S.M. Diversity, abundance, and species composition of ants in urban green spaces. Urban Ecosyst. 2010, 13, 425-441. [CrossRef]

145. Ivanov, K.; Keiper, J. Ant (Hymenoptera: Formicidae) diversity and community composition along sharp urban forest edges. Biodivers. Conserv. 2010, 19, 3917-3933. [CrossRef]

146. Lessard, J.-P.; Christopher, M. The effects of urbanization on ant assemblages (Hymenoptera: Formicidae) associated with the Molson Nature Reserve, Quebec Jean-Philippe. Entomol. Soc. Can. 2005, 137, 215-225. [CrossRef]

147. Clarke, K.M.; Fisher, B.L.; Lebuhn, G. The influence of urban park characteristics on ant (Hymenoptera, Formicidae) communities. Urban Ecosyst. 2008, 11, 317-334. [CrossRef]

148. King, T.G.; Green, S.C. Factors affecting the distribution of pavement ants (Hymenoptera: Formicidae) in Atlantic coast urban fields. Entomol. News 1995, 106, 224-228.

149. Staubus, W.J.; Boyd, E.S.; Adams, T.A.; Spear, D.M.; Dipman, M.M.; Meyer, W.M. Ant communities in native sage scrub, nonnative grassland, and suburban habitats in Los Angeles County, USA: Conservation implications. J. Insect Conserv. 2015, 19, 669-680. [CrossRef]

150. Pećarević, M.; Danoff-Burg, J.; Dunn, R.R. Biodiversity on broadway—enigmatic diversity of the societies of ants (Formicidae) on the streets of New York City. PLoS ONE 2010, 5, 1-8. [CrossRef]

151. Thompson, B.; McLachlan, S. The effects of urbanization on ant communities and myrmecochory in Manitoba, Canada. Urban Ecosyst. 2007, 10, 43-52. [CrossRef]

152. Villar, P.G.; Ríos-Casanova, L. Diversidad de hormigas (Hymenoptera: Formicidae) de La Cantera Oriente, una reserva dentro de la ciudad de México. Dugesiana 2020, 27, 29-36.

153. Stahlschmidt, Z.R.; Johnson, D. Moving targets: Determinants of nutritional preferences and habitat use in an urban ant community. Urban Ecosyst. 2018, 21, 1151-1158. [CrossRef]

154. Marussich, W.A.; Faeth, S.H. Effects of urbanization on trophic dynamics of arthropod communities on a common desert host plant. Urban Ecosyst. 2009, 12, 265-286. [CrossRef]

155. Pacheco, R.; Vasconcelos, H.L. Invertebrate conservation in urban areas: Ants in the Brazilian Cerrado. Landsc. Urban Plan. 2007, 81, 193-199. [CrossRef]

156. Santos, M.N.; Delabie, J.H.C.; Queiroz, J.M. Biodiversity conservation in urban parks: A study of ground-dwelling ants (Hymenoptera: Formicidae) in Rio de Janeiro City. Urban Ecosyst. 2019, 22, 927-942. [CrossRef]

157. Santos-Silva, L.; Vicente, R.E.; Feitosa, R.M. Ant species (Hymenoptera, Formicidae) of forest fragments and urban areas in a meridional amazonian landscape. Check List 2016, 12, 1-7. [CrossRef]

158. De Souza, D.R.; Dos Santos, S.G.; De Munhae, C.B.; De Morini, M.S.C. Diversity of epigeal ants (Hymenoptera: Formicidae) in urban areas of Alto Tietê. Sociobiology 2012, 59, 703-717. [CrossRef]

159. Lutinski, J.A.; Lopes, B.C.; de Morais, A.B.B. Diversidade de formigas urbanas (Hymenoptera: Formicidae) de dez cidades do sul do Brasil. Biota Neotrop. 2013, 13, 332-342. [CrossRef]

160. Munhae, C.d.B.; Souza-Campana, D.R.d.; Kamura, C.M.; Castro Morini, M.S.d. Ant communities (Hymenoptera: Formicidae) in urban centers of the Alto Tietê, São Paulo, Brazil. Arq. Inst. Biol. (Sao Paulo) 2015, 82, 1-5. [CrossRef]

161. Morini, M.S.d.C.; Munhae, C.d.B.; Leung, R.; Candiani, D.F.; Voltolini, J.C. Comunidades de formigas (Hymenoptera, Formicidae) em fragmentos de Mata Atlântica situados em áreas urbanizadas. Iheringia. Série Zool. 2007, 97, 246-252. [CrossRef] 
162. Iop, S.; Lutinski, J.A.; Roberto, F.; Garcia, M. Formigas urbanas da cidade de Xanxerê, Santa Catarina, Brasil. Biotemas 2009, 22, 55-64. [CrossRef]

163. Matheus Caldart, V.; Iop, S.; Antonio Lutinski, J.; Roberto Mello Garcia, F. Diversidade de formigas (Hymenoptera, Formicidae) do perímetro urbano do município de Chapecó, Santa Catarina, Brasil. Rev. Bras. Zoociências 2012, 14, 81-94.

164. Ilha, C.; Maestri, R.; Antonio Lutinski, J. Assembleias de formigas (Hymenoptera: Formicidae) em áreas verdes urbanas de Chapecó, Santa Catarina. Acta Ambient. Catarin. 2017, 14, 39-50.

165. Josens, R.; Sola, F.; Lois-Milevicich, J.; Mackay, W. Urban ants of the city of Buenos Aires, Argentina: Species survey and practical control. Int. J. Pest Manag. 2017, 63, 1-11. [CrossRef]

166. Kamura, C.M.; Morini, M.S.C.; Figueiredo, C.J.; Bueno, O.C.; Campos-Farinha, A.E.C. Ant communities (Hymenoptera: Formicidae) in an urban ecosystem near the Atlantic Rainforest. Braz. J. Biol. 2007, 67, 635-641. [CrossRef]

167. Santiago, G.S.; Campos, R.B.F.; Ribas, C.R. How does landscape anthropization affect the myrmecofauna of urban forest fragments? Sociobiology 2018, 65, 441-448. [CrossRef]

168. De Souza-Campana, D.R.; Da Silva, O.G.M.; Menino, L.; Morini, M.S.D.C. Epigaeic ant (hymenoptera: Formicidae) communities in urban parks located in atlantic forest biome. Check List 2016, 12, 1967. [CrossRef]

169. Piva, A.; Campos, A.E.D.C. Ant community structure (Hymenoptera: Formicidae) in two neighborhoods with different urban profiles in the city of São Paulo, Brazil. Psyche (Lond.) 2012, 2012,1-8. [CrossRef]

170. Alfonso Simonetti, J.; Matienzo Brito, Y.; Vázquez Moreno, L. Fauna de hormigas (Hymenoptera: Formicidae) asociadas a un sistema de producción agrícola urbano. Fitosanidad 2010, 14, 153-158.

171. Ribeiro, F.M.; Sibinel, N.; Ciocheti, G.; Campos, A.E.C. Analysis of ant communities comparing two methods for sampling ants in an urban park in the city of São Paulo, Brazil. Sociobiology 2012, 59, 971-984. [CrossRef]

172. Lutinski, J.A.; Roberto Mello Garcia, F. Análise faunística de Formicidae (Hymenoptera: Apocrita) em ecossistema degradado no município de Chapecó, Santa Catarina. Biotemas 2005, 18, 73-86.

173. Lange, D.; Vilela, A.; Erdogmus, G.; Barbosa, A. Temporal dynamic of foraging of epigeic ants in an urban forest fragment. Bioscience 2015, 31, 1501-1511. [CrossRef]

174. Starr, C.K.; Ballah, S.T. Urban Ant Fauna of Port of Spain, Trinidad, West Indies. Living World J. Trinidad Tobago F. Nat. Club 2017, 49-50.

175. Soares, N.S.; Almeida, L.D.O.; Gonçalves, C.A.; Marcolino, M.T.; Bonetti, E.A.M. Survey of ants (Hymenoptera: Formicidae) in the urban area of Uberlândia, MG, Brazil. Neotrop. Entomol. 2006, 35, 324-328. [CrossRef]

176. Peel, M.C.; Finlayson, B.L.; McMahon, T.A. Updated world map of the Köppen-Geiger climate classification. Hydrol. Earth Syst. Sci. 2007, 11, 1633-1644. [CrossRef]

177. Macao Meteorological and Geophysical Bureau Macao Climate: 30-year Statistics of Some Meteorological Elements. Available online: https://www.smg.gov.mo/en/subpage/348/page/252 (accessed on 1 June 2021).

178. Governo da Região Administrativa Especial de Macau Dirreção dos Serviços de Cartografia e Cadastro Land Area Statistics. Available online: http:/www.dscc.gov.mo/ENG/knowledge/geo_statistic.html (accessed on 23 June 2021).

179. IACM Macao Forest. Joint Publishing (Hong Kong). 2017; ISBN1 978-962-04-4138-7. ISBN2 962-04-4138-9.

180. Booher, D.; Macgown, J.A.; Hubbell, S.P.; Duffield, R.M. Density and Dispersion of Cavity Dwelling Ant Species in Nuts of Eastern US Forest Floors. Trans. Am. Entomol. Soc. 2017, 143, 79-93. [CrossRef]

181. R Core Team. R: A Language and Environment for Statistical Computing; R Foundation for Statistical Computing: Vienna, Austria, 2020.

182. Liu, C.; Guénard, B.; Garcia, F.H.; Yamane, S.; Blanchard, B.; Yang, D.R.; Economo, E. New records of ant species from Yunnan, China. Zookeys 2015, 477, 17-78. [CrossRef]

183. Guénard, B.; Weiser, M.D.; Dunn, R.R. Global models of ant diversity suggest regions where new discoveries are most likely are under disproportionate deforestation threat. Proc. Natl. Acad. Sci. USA 2012, 109, 7368-7373. [CrossRef]

184. Wickham, H. ggplot2: Elegant Graphics for Data Analysis; Springer: New York, NY, USA, 2016; ISBN 978-3-319-24277-4.

185. Hsieh, T.C.; Ma, K.H.; Chao, A. iNEXT: An R package for rarefaction and extrapolation of species diversity (Hill numbers). Methods Ecol. Evol. 2016. [CrossRef]

186. Guénard, B.; Weiser, M.D.; Gómez, K.; Narula, N.; Economo, E.P. The Global Ant Biodiversity Informatics (GABI) database: Synthesizing data on the geographic distribution of ant species (Hymenoptera: Formicidae). Myrmecol. News 2017, 24, 83-89. [CrossRef]

187. Janicki, J.; Narula, N.; Ziegler, M.; Guénard, B.; Economo, E.P. Visualizing and interacting with large-volume biodiversity data using client-server web-mapping applications: The design and implementation of antmaps.org. Ecol. Inform. 2016, 32, 185-193. [CrossRef]

188. Wheeler, W.M. Chinese ants. Bull. Mus. Comp. Zool. 1921, 64, 529-547.

189. Wheeler, W.M. Ants collected by Professor F. Silvestri in China. Boll. Lab. Zool. Gen. Agrar. R. Ist. Super. Agrar. Portici 1928, 22, 3-38.

190. Wheeler, W.M. A list of the known Chinese ants. Peking Nat. Hist. Bull. 1930, 5, 53-81.

191. Wu, C.F. Catalogus Insectorum Sinensium, Volume VI; The Fan Memorial Institute of Biology, Yenching University: Beijing, China, 1941. 
192. Tang, K.L.; Pierce, M.P.; Guénard, B. Review of the genus Strumigenys (Hymenoptera, Formicidae, Myrmicinae) in Hong Kong with the description of three new species and the addition of five native and four introduced species records. Zookeys 2019, 831, 1-48. [CrossRef]

193. Zhou, S.-Y. Ants of Guangxi; Guangxi Normal University Press: Guangxi, China, 2001.

194. Xu, Z. A systematic study on Chinese species of the ant genus Oligomyrmex Mayr (Hymenoptera: Formicidae). Acta Zootaxonomica Sin. 2003, 28, 310-322.

195. Hua, L. List of Chinese insects Vol. IV; Sun Yatsen University Press: Guangzhou, China, 2006; ISBN 9787306017017.

196. Eguchi, K. A revision of Northern Vietnamese species of the ant genus Pheidole (Insecta: Hymenoptera: Formicidae: Myrmicinae). Zootaxa 2008, 1902, 1-118. [CrossRef]

197. Bharti, H.; Kumar, R. Five new species of Dilobocondyla (Hymenoptera: Formicidae) with a revised key to the known species. Asian Myrmecol. 2013, 5, 29-44.

198. Dlussky, G.M.; Radchenko, A.G. The ants (Hymenoptera, Formicidae) of Vietnam. Subfamily Pseudomyrmicinae. Subfamily Myrmicinae (Tribes Calyptomyrmecini, Meranoplini, Cataulacini). Available online: GBIF.org (accessed on 21 July 2021).

199. Fisher, B.L. A new species of Probolomyrmex from Madagascar. In Advances in Ant Systematics (Hymenoptera: Formicidae): Homage to E.O. Wilson-50 Years of Contributions; American Entomological Institute: Gainesville, FL, USA, 2007.

200. Shattuck, S.O.; Gunawardene, N.R.; Heterick, B. A revision of the ant genus Probolomyrmex (Hymenoptera: Formicidae: Proceratiinae) in Australia and Melanesia. Zootaxa 2012, 3444, 40-50. [CrossRef]

201. Taylor, R.W. A monographic revision of the rare tropicopolitan ant genus Probolomyrmex Mayr (Hymenoptera: Formicidae). Trans. R. Entomol. Soc. Lond. 1965, 117, 345-365. [CrossRef]

202. Economo, E.P.; Narula, N.; Friedman, N.R.; Weiser, M.D.; Guénard, B. Macroecology and macroevolution of the latitudinal diversity gradient in ants. Nat. Commun. 2018, 9, 1-8. [CrossRef]

203. Nadkarni, N.M.; Longino, J.T. Invertebrates in Canopy and Ground Organic Matter in a Neotropical Montane Forest, Costa Rica. Biotropica 1990, 286-289. [CrossRef]

204. Schmidt, F.A.; Solar, R.R.C. Hypogaeic pitfall traps: Methodological advances and remarks to improve the sampling of a hidden ant fauna. Insectes Soc. 2010, 57, 261-266. [CrossRef]

205. Ryder Wilkie, K.T.; Mertl, A.L.; Traniello, J.F.A. Biodiversity below ground: Probing the subterranean ant fauna of Amazonia. Naturwissenschaften 2007, 94, 725-731. [CrossRef]

206. Tschinkel, W.R. Back to basics: Sociometry and sociogenesis of ant societies (Hymenoptera: Formicidae). Myrmecol. News 2011, $14,49-54$.

207. Tschinkel, W.R. Insect sociometry, a field in search of data. Insectes Soc. 1991, 38, 77-82. [CrossRef]

208. Gotelli, N.J.; Ellison, A.M.; Dunn, R.R.; Sanders, N.J. Counting ants (Hymenoptera: Formicidae): Biodiversity sampling and statistical analysis for myrmecologists. Myrmecolo. News 2011, 15, 13-19.

209. Longino, J.T.; Coddington, J.; Colwell, R.K. The ant fauna of a tropical rain forest: Estimating species richness three different ways. Ecology 2002, 83, 689-702. [CrossRef]

210. Lee, R.H.; Guénard, B. Choices of sampling method bias functional components estimation and ability to discriminate assembly mechanisms. Methods Ecol. Evol. 2019, 10, 867-878. [CrossRef]

211. Yusah, K.M.; Fayle, T.M.; Harris, G.; Foster, W.A. Optimizing diversity assessment protocols for high canopy ants in tropical rain forest. Biotropica 2012, 44, 73-81. [CrossRef]

212. Kaspari, M.; Pickering, J.; Windsor, D. The reproductive flight phenology of a neotropical ant assemblage. Ecol. Entomol. 2001, 50, 382-390. [CrossRef]

213. Chong, C.S.; Li, D. Effects of forest disturbance on ant diversity in Singapore. Dep. Biol. Sci. Natl. Univ. Singap. $2003,1-4$.

214. Bourguignon, T.; Dahlsjö, C.A.L.; Jacquemin, J.; Gang, L.; Wijedasa, L.S.; Evans, T.A. Ant and termite communities in isolated and continuous forest fragments in Singapore. Insectes Soc. 2017, 64, 505-514. [CrossRef]

215. MacGown, J.A.; Hill, J.G.; Deyrup, M.A. Brachymyrmex patagonicus (Hymenoptera: Formicidae), an emerging pest species in the southeastern United States. Fla. Entomol. 2007, 90, 457-464. [CrossRef]

216. Guénard, B. First record of the emerging global pest Brachymyrmex patagonicus Mayr 1868 (Hymenoptera: Formicidae) from continental Asia. Asian Myrmecol. 2018, 10, 1-6. [CrossRef]

217. Tschinkel, W.R. The ecological nature of the fire ant: Some aspects of colony function and some unanswered questions. In Fire Ants and Leafcutter Ants: Biology and Management; Lofgren, C.S., Vander Meer, R.K., Eds.; Avalon Publishing: New York, NY, USA, 1986; pp. 72-87.

218. Tschinkel, W.R. Distribution of the fire ants Solenopsis invicta and S. geminata (Hymenoptera: Formicidae) in northern Florida in relation to habitat and disturbance. Ann. Entomol. Soc. Am. 1988, 81, 76-81. [CrossRef]

219. Tschinkel, W.R.; King, J.R. The Role of Habitat in the Persistence of Fire Ant Populations. PLoS ONE 2013, 8, 1-8. [CrossRef]

220. Hoffmann, B.D.; Parr, C.L. An invasion revisited: The African big-headed ant (Pheidole megacephala) in northern Australia. Biol. Invasions 2008, 10, 1171-1181. [CrossRef]

221. Porter, S.D.; Savignano, D.A. Invasion of polygyne fire ants decimates native ants and disrupts arthropod community. Ecology 1990, 71, 2095-2106. [CrossRef]

222. Wetterer, J.K. Biology and Impacts of Pacific Island Invasive Species. 3. The African Big-Headed Ant, Pheidole megacephala (Hymenoptera: Formicidae). Pac. Sci. 2007, 61, 437-456. [CrossRef] 
223. Lee, R.H.; Wang, C.L.; Guénard, B. The ecological implications of rubber-based agroforestry: Insect conservation and invasion control. J. Appl. Ecol. 2020, 57, 1605-1618. [CrossRef]

224. Liu, C.; Fischer, G.; Garcia, F.H.; Yamane, S.; Liu, Q.; Peng, Y.Q.; Economo, E.P.; Guénard, B.; Pierce, N.E. Ants of the Hengduan Mountains: A new altitudinal survey and updated checklist for Yunnan Province highlight an understudied insect biodiversity hotspot. Zookeys 2020, 978, 1-171. [CrossRef]

225. Lockwood, J.L.; Cassey, P.; Blackburn, T. The role of propagule pressure in explaining species invasions. Trends Ecol. Evol. 2005, 20, 223-228. [CrossRef]

226. Ellison, A.M. Out of Oz: Opportunities and challenges for using ants (Hymenoptera: Formicidae) as biological indicators in north-temperate cold biomes. Myrmecol. News 2012, 17, 105-119.

227. Brady, S.G.; Ward, P.S. Morphological phylogeny of army ants and other dorylomorphs (Hymenoptera: Formicidae). Syst. Entomol. 2005, 30, 593-618. [CrossRef]

228. Boswell, G.P.; Britton, N.F.; Franks, N.R. Habitat fragmentation, percolation theory and the conservation of a keystone species. Proc. R. Soc. B Biol. Sci. 1998, 265, 1921-1925. [CrossRef]

229. Schöning, C.; Kinuthia, W.; Boomsma, J.J. Does the Afrotropical army ant Dorylus (Anomma) molestus go extinct in fragmented forests? J. East Afr. Nat. Hist. 2006, 95. [CrossRef] 